NUREG/CR-1858

PNL-3666

\title{
A Review of Removable Surface Contamination on Radioactive Materials Transportation Containers
}

Prepared by W. E. Kennedy, Jr., E. C. Watson, D. W. Murphy,

B. J. Harrer, R. Harty, J. M. Aldrich

Pacific Northwest Laboratory

Operated by

Battelle Memorial Institute

Prepared for

U.S. Nuclear Regulatory

Commission 


\section{NOTICE}

This report was prepared as an account of work sponsored by an agency of the United States Government. Neither the United States Government nor any agency thereof, or any of their employees, makes any warranty, expressed or implied, or assumes any legal liability or responsibility for any third party's use, or the results of such use, of any information, apparatus product or process disclosed in this report, or represents that its use by such third party would not infringe privately owned rights.

Printed copy price: $\$ 6.00$ 


\section{A Review of Removable Surface Contamination on Radioactive Materials Transportation Containers}

Manuscript Completed: April 1981

Date Published: May 1981

Prepared by

W. E. Kennedy, Jr., E. C. Watson, D. W. Murphy,

B. J. Harrer, R. Harty, J. M. Aldrich

Pacific Northwest Laboratory

Aichland, WA 99352

Prepared for

Division of Risk Analysis

Office of Nuclear Regulatory Research

U.S. Nuclear Regulatory Commission

Washington, D.C. 20555

NRC FIN B2133 



\section{ABSTRACT}

This report contains the results of a study sponsored by the U.S. Nuclear Regulatory Commission (NRC) of removable surface contamination on radioactive materials transportation containers. The purpose of the study is to provide information to the NRC during their review of existing regulations. Data was obtained from both industry and literature on three major topics: 1) radiation doses, 2) economic costs, and 3) contamination frequencies. Containers for four categories of radioactive materials are considered including radiopharmaceuticals, industrial sources, nuclear fuel cycle materials, and low-level radioactive waste. Assumptions made in this study use current information to obtain realistic yet conservative estimates of radiation dose and economic costs. Collective and individual radiation doses are presented for each container category on a per container basis. Total doses, to workers and the public, are also presented for spent fuel cask and low-level waste drum decontamination. Estimates of the additional economic costs incurred by lowering current limits by factors of 10 and 100 are presented. Current contamination levels for each category of container are estimated from the data collected. The information contained in this report is designed to be useful to the NRC in preparing their recommendations for new regulations. 
TABLE OF CONTENTS

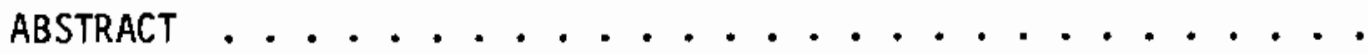

LIST OF FIGURES .......................... ix

LIST OF TABLES ........................ xi

ACKNOWLEDGMENTS AND STUDY CONTRIBUTORS .......... X XV

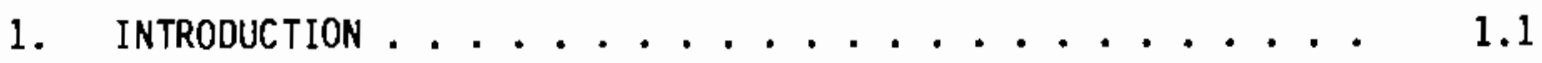

1.1 Purpose ........................... 1.1

1.2 Current Regulations .............. 1.2

1.3 Application of Data .................. 1.3

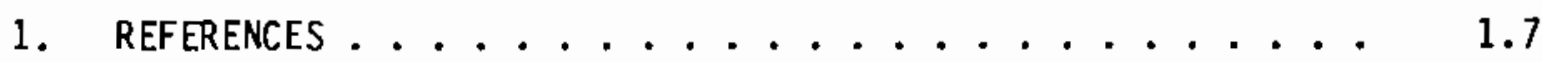

2. GENERAL FINDINGS AND SUMMARY OF RESULTS ......... 2.1

2.1 General Findings . . . . . . . . . . . 2.1

2.2 Summary of Results ............... 2.2

2.2.1 Radiation Dose Evaluation ......... 2.2

2.2.2 Economic Cost Analys is ........... 2.7

2.2.3 Contamination Frequency Distributions .... 2.10

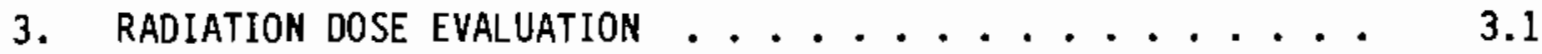

3.1 Radiation Exposure Pathways and Dose Models ...... 3.1

3.1 .1 Direct Ingestion ............... 3.2

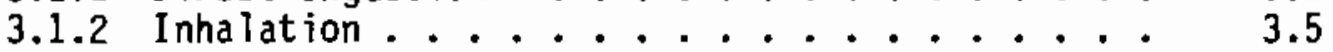

3.1.3 Direct Exposure ............. 3.14

3.2 Radiopharmaceuticals ........... 3.16

3.2.1 Reference Radiopharmaceutical Container . . . 3.18

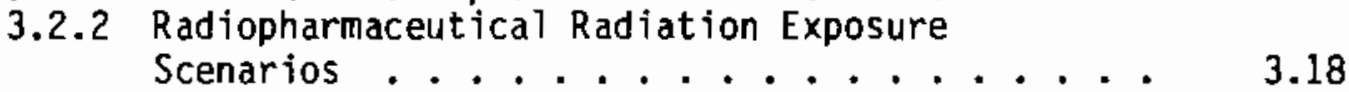

3.2.3 Radiation Doses from Radiopharmaceutical
Transportation Containers . . . . . 3.20

3.3 Industrial Sources . . . . . . . . . . 3.24

3.3.1 Reference Industrial Source Container . . . . 3.26

3.3.2 Industrial Source Radiation Exposure Scenarios . $\quad 3.26$

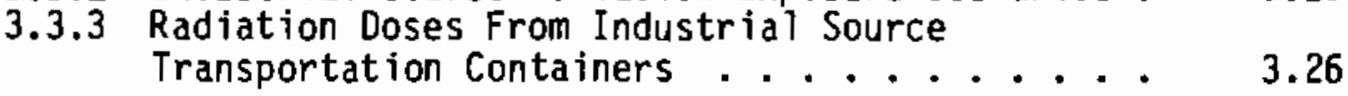


3.4 Nuc lear Fuel Cyc le Materials . . . . . . . . 3.30

3.4.1 Reference Nuclear Fuel Cycle Materials

Containers ............... 3.32

3.4.2 Nuclear Fuei Cycle Materials Radiation Exposure

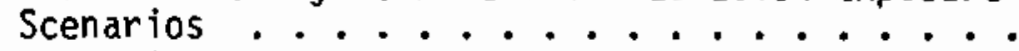

3.4.3 Radiation Doses from Nuctear Fuel Cycle ... 3.34

3.4 .4 Spent Fuel Cask Decontamination ...... 3.40

3.5 Low-Leve1 Radioactive Waste . . . . . . . . . . 3.44

3.5.1 Reference Low-Leve 1 Waste Container .... $\quad 3.46$

3.5.2 Low-Level Waste Radiation Exposure Scenarios . $\quad 3.47$

3.5.3 Radiation Doses from Low-Level Radioactive

3.5.4 Low-Level Radioactive Waste Container Decontamination ............ 3.52

3.6 Radiation Dose Evaluation Sumary . . . . . . 3.57

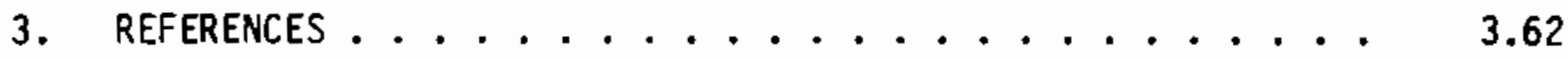

4. ECONOMIC COST ANALYSIS .................. 4.1

4.1 Monitoring Time Costs ............. 4.2

4.1.1 Detection Efficiency............ 4.7

4.1.2 Background Radiation ............. 4.8 4.8

4.1.3 Smearing Technique ............ 4.9

4.1.4 Mix of Beta-Gamma Radiation . . . . . . . 4.9

4.1.5 Monitoring Costs Per Hour ........ 4.10

4.1.6 Relative Counting Error of the Counting ..... 4.11

4.1 .7 Monitoring cost Results . . . . . 4.11

4.2 Instrumentation costs . . . . . . . . . . 4.17

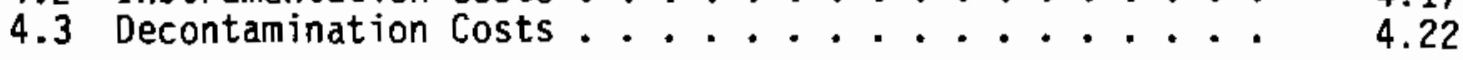

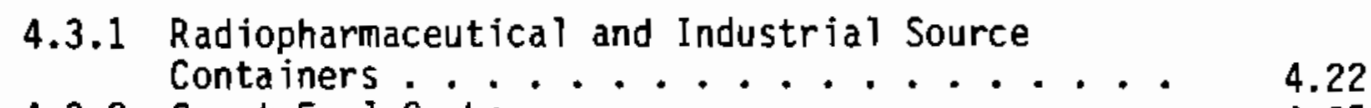

4.3.2 Spent Fuel Casks............ 4.25

4.3.3 Low-Level Waste Drums ........... 4.31

4.4 Total Direct Cost Impacts of Reducing the Limits for Removable Contamination.......... 4.32

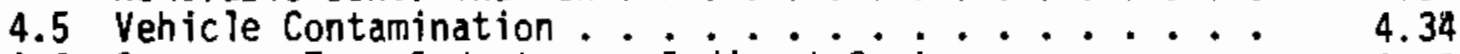

4.6 Comments From Industry on Indirect costs $\ldots \ldots . . .49$

4.7 Economic Cost Analys is Sumary ......... 4.41

4. REFERENCES .......................... 4.44 


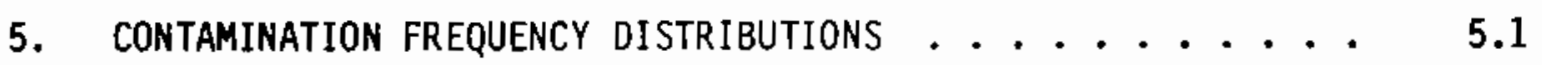

5.1 Instrumentation . .................. 5.1

5.2 Procedures .................. 5.2

5.3 Radiopharmaceuticals ............... 5.4

5.4 Industrial Sources .............. 5.14

5.5 Nuclear Fuel Cycle Shipments ........... 5.14

5.5.1 Uranium Shipments ............. 5.14

5.5.2 Spent Fuel Shipments............ 5.17

5.5.3 Spent Fue Cask Surface Sweating ....... 5.20

5.6 Low-Level Radioactive Waste . . . . . . . . 5.32

5.7 Frequency Distribution Sumary . . . . . . . . . 5.32

6. COMMENTS ON RESULTS. . . . . . . . . . . . . . 6.1 



\section{LIST OF FIGURES}

2.2-1 Example Collective Doses From Surface Contamination on Low-Level Radioactive Waste Transportation

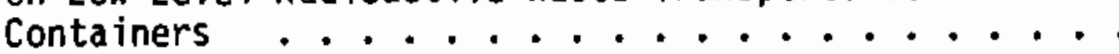

2.2-2 Example Total Dose Versus Decontamination Time for 129 I Starting at a Level of $10^{-4} \mu \mathrm{Ci} / \mathrm{cm}^{2}$ - Low-

Level Radioactive Waste ...........

2.2-3 Estimated Economic Costs For Reducing Removable

Surface Contamination Limits ..........

2.2-4 Frequency Distribution for Radiopharmaceuticals -

Alpha Contamination ............

2.2-5 Frequency Distribution for Radiopharmaceuticals Beta-Garma Contamination . . . . . . . . . . . .

3.1-1 Pasquill Type $F$ Centerline $X / Q^{\prime}$ Values for Building-Wake Modifications Factors versus Downwind

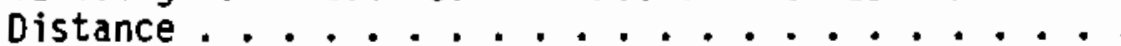

3.4-1 Total Dose versus Decontamination Time for Spent Fuel Beta-Ganma Mixture - Starting at a Leve 1 of $10^{-4} \mu \mathrm{Ci} / \mathrm{cm}^{2}$ - DF $=10 / 30$ minutes .............

3.4-2 Total Dose versus Decontamination Time for Spent Fuel Beta-Garma Mixture - Starting at a Level of $10^{-4} \mu \mathrm{Ci} / \mathrm{cm}^{2}$ - $\mathrm{DF}=2 / 30$ minutes ............

3.4-3 Population and Occupational Dose Comparison for Spent Fuel Cask Decontamination.............

3.5-1 Total Dose Versus Decontamination Time for 129 I Starting at a Level of $10^{-4} \mu \mathrm{Ci} / \mathrm{cm}^{2} \ldots . . . .$.

3.5-2 Total Dose versus Decontamination Time for Low-Leve 1 Waste Drums - 129 I Starting at a Level of $10-5 \mu \mathrm{Ci} / \mathrm{cm}^{2}$

3.5-3 Total Dose versus Decontamination Time for Low-Level Waste Drums - 60Co Starting at a Level of

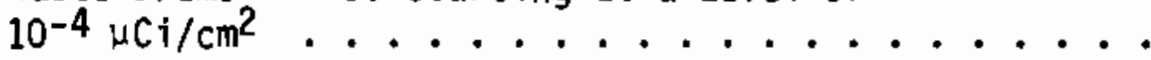

3.6-1 Collective Doses From Surface Contamination on Radiopharmaceutical Transportation Containers .....

3.6-2 Collective Doses From Surface Contamination on Industrial Source Materials Transportation Containers. 
3.6-3 Collective Doses From Surface Contamination on Nuclear Fuel Cycle Transportation Containers . . . . .

3.6-4 Collective Doses From Surface Contamination on Spent

Fue T Transportation Containers .........

3.6-5 Collective Doses From Surface Contamination on LowLevel Radioactive Waste Transportation Containers . . .

4.3-1 Cost-Contamination Relationship For Spent Fuel Casks with Two Decontaminations..........

4.3-2 Cost-Contamination Relationship For Spent Fuel Casks with Three Decontaminations..........

4.5-1 Cost-Contamination Relationship For Vehicles With One Decontamination .............

4.5-2 Cost-Contamination Relationship For Vehicles With Two Decontaminations ............

5.7-1 Frequency Distribution for Radiopharmaceuticals

- Alpha Contamination ...........

5.7-2 Frequency Distribution for Radiopharmaceutica is

- Beta-Gantma Contamination ..........

5.7-3 Frequency Distribution for Industrial Sources Alpha Contamination ............

5.7-4 Frequency Distribution for Industrial Sources -

Beta-Gama Contamination ...........

5.7-5 Frequency Distribution for Uranium Shipments Alpha Contamination ...........

5.7-6 Frequency Distribution for Uranium Shipments Beta-Garma Contamination ...........

5.7-7 Frequency Distribution for Spent Fue T Alpha Contamination ............

5.7-8 Frequency Distribution for Spent Fuel Beta-Gamma Contamination ...........

5.7-9 Frequency Distribution for Low-Level Radioactive Waste - Alpha Contamination .........

5.7-10 Frequency Distribution for Low-Leve 1 Radioactive Waste - Beta-Gamma Contamination ......... 


\section{LIST OF TABLES}

1.2-1 Current Removable Surface Contamination Limits for

Transportation Containers ...........

3.1-1 Reported Surface Contamination Ingestion

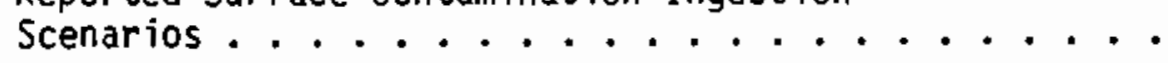

3.1-2 Solubility Classes for Elements From Literature

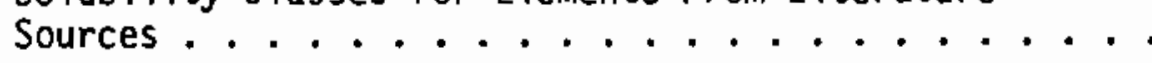

3.1-3 Reported Resuspension Information . . . . . . 3.8

3.2-1 Common Radiopharmaceuticals ........... 3.17

3.2-2 Individual and Collective to Composite Workers From

Surface Contamination - Radiopharmaceutical

Transportation Containers ...........

3.2-3 Doses to the Composite Individual in the Public From Surface Contamination - Radiopharmaceutical

Transportation Containers ...........

3.2-4 Collective Dose to the Composite Population Group

From Surface Contamination - Radiopharmaceutical

Transportation Containers . . . . . . . .

3.3-1 Common Industrial Source Radionuclides . . . . . 3.25

3.3-2 Individual and Collective Doses to Composite Workers

From Surface Contamination - Industrial Source

Material Transportation Containers ........

3.3-3 Doses to Composite Individual in the Public From Surface Contamination - Industrial Source Material

Transportation Containers ..........

3.3-4 Collective Doses to the Composite Population Group From Surface Contamination - Industrial Source Material Transportation Containers . . . . . . . .

3.4-1 Cormon Nuc lear Fuel Cycle Radionuclides . . . . . . 3.31

3.4-2 Individual and Collective Doses to Composite Workers From Surface Contamination - Nuclear Fuel Cycle Materials Transportation Containers - $2380 \ldots . . .$.

3.4-3 Collective Doses to the Composite Population Group From Surface Contamination - Nuclear Fuel Cycle Materials Transportation Containers - 238U ..... 
3.4-4 Individual and Collective Doses to Composite Workers

From Surface Contamination - Nuclear Fuel Cycle

Transportation Containers - Spent Fuel Radiotoxic . . .

3.4-5 Collective Doses to the Composite Population Group

From Surface Contamination - Nuclear Fuel Cycle

Materials Transportation Containers - Spent Fuel ...

3.5-1 Representative Radionuclides in Low-Level Waste

Shipments ..............

3.5-2 Standard Low-Level Radioactive Waste Shipping

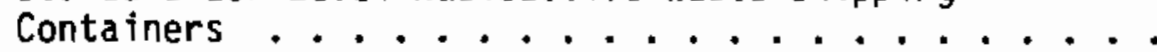

3.5-3 Individual and Collective Doses to Composite Workers

From Surface Contamination - Low-Level Radioactive Waste

Transportation Containers ...........

3.5-4 Collective Doses to the Composite Population Group

From Surface Contamination - Low-Level Radioactive

Waste Transportation Containers..........

4.1-1 Summary of the Data Used in the Monitoring Time

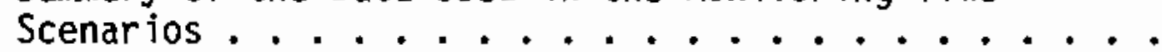

4.1-2 Counting Times and Counting Costs per Sample at

Current DOT Beta-Gamma Limits ...........

4.1-3 Counting Times and Counting Costs per Sample at Levels 10 Times Below Current DOT Beta-Gamma Limits .....

4.1-4 Counting Times and Counting Costs per Sample at Leve 1s 100 Times Below Current D0T Beta-Gamma Limits.

4.1-5 Counting Times and Counting Costs per Sample at Levels 1000Times Below Current DOT Beta-Gamma Limits.....

4.1-6 Suggested Monitoring Cost Impacts per Smear of Lowering Removab ie Contamination Levels for Alpha and Beta-Ganma to 10 and 100 Times Below Current Limits ................

4.2-1 Detection 1nstruments Currentiy in Use at Representative Industrial Sites.........

4.2-2 Approximate Capital Costs for Typical Laboratory and Field Radiation Detection Instruments.......

4.2-3 Least-Cost per Container for Reaching Levels 10 Times Below Current Limits 
4.2-4 Least-Cost per Container for Reaching Levels 100

Times Below Current Limits .............

4.4-1 Total Direct Cost Impacts per Container for Monitoring Instrumentation, and Decontamintion of Each Container

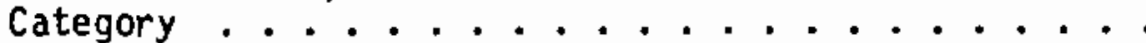

4.5-1 Total Estimated Impacts on the Cost of Vehicle

Monitoring per Shipment for Reduced Surface

Contamination Limits ............. 4.36

5.1-1 Calibration of the Eberline MS-2 Miniscaler with the Eberline Alpha RD-13 and Beta RD-13 External Detector Probes ...................... 5.3

5.3-1 Frequency Distribution Data for Radiopharmaceuticals . $\quad 5.5$

5.4-1 Frequency Distribution Data for Industrial Sources . . 5.15

5.5-1 Frequency Distribution Data for Nuclear Fuel Cycle

5.5-2 Frequency Distribution Data for Spent Fuel Shipments Beta-Ganma .................... 5.21

5.5-3 Frequency Distribution Data for Spent Fue1 Shipments Alpha ................... 5.30

5.6-1 Frequency Distribution Data for Low-Level Waste . . . . 5.33 


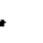




\section{ACKNOWLEDGMENTS}

The authors would like to thank all of the companies and their representatives who provided data and information for our analysis. Without their help and cooperation our tasks would have been impossible.

\section{STUDY CONTR IBUTORS}

\section{STUDY LEADER}

W. E. Kennedy, Jr,

CHAPTER 1 - INTRODUCTION

W. E. Kennedy, Jr.

CHAPTER 2 - SUMMARY OF RESULTS

W. E. Kennedy, Jr.

CHAPTER 3 - RADIATION DOSE EVALUATION

W. E. Kennedy, Jr.

E. C. Watson

CHAPTER 4 - ECONOMIC COST ANALYSIS

B. J. Harrer

CHAPTER 5 - CONTAMINATION FREQUENCY DISTRIBUTIONS

D. W. Murphy

R. Harty

J. M. Aldrich

CHAPTER 6 - COMMENTS FROM INDUSTRY

W. E. Kennedy, Jr.

B. J. Harrer

D. W. Murphy

R. Harty 



\title{
1. INTRODUCTION
}

In a report by the Comptroller General of the General Accounting Office (GAO) to the Congress (May 7, 1979), it is stated that "Federal actions are needed to improve safety and security of nuclear materials transportation." The GAO further stated that:

\begin{abstract}
"Over 2 million packages of radioactive materials are shipped each year. The Nuc lear Regulatory Commiss ion est imates that shipments will more than double to about 5.5 million annually by 1985 . . GAO recommends several changes to existing procedures that would improve safety and strengthen the security of nuclear shipments."
\end{abstract}

The GAO specifically reconmended that the chairman of the ARC and the Secretary of Transportation should "reduce permissible contamination levels for packages and vehicles to levels compatible with what industry can reasonably achieve." This report contains the results of a study sponsored by the U.S. Nuclear Regulatory Commission (NRC) to provide information about removable surface contamination levels on radioactive materials transportation containers. It also provides a general overview of the current status of removable surface contamination relating to the transport of radioactive materials. The information is based on data collected from both industry and literature, and addresses three major topics: 1) radiation doses, 2) economic costs, and 3) contamination frequencies. Containers for four categories of radioactive materials are considered including radiopharmaceuticals, industrial sources, nuclear fuel cycle materials, and low-level radioactive waste.

\subsection{Purpose}

The purpose of this study is to develop current information regarding removable surface contamination on shipping containers under existing regulations and to explore the impacts of regulatory change. This study was authorized to provide data to be used by the NRC in determining what reduced contamination levels can be "reasonably achieved" by industry. 
It is not the purpose of this report to recomend such limits; however, data is provided on the estimated radiation doses and economic costs for a range of levels from 10 times the current limits down to $1 \%$ of the current limits.

\subsection{Current Regulations}

Current regulations concerning removable surface contamination on radioactive materials transportation containers are given in the U.S. Code of Federal Regulations, Title 49 part 173, 49 CFR 173 (1979). Removable * contamination is considered to be significant if the contamination level averaged over $300 \mathrm{~cm}^{2}$ of container surface exceeds the values given in Table 1.2-1.

In addition to the maximum permissible levels listed in Table 1.2-1, the regulations state that "a sufficient number of measurements must be taken in the most appropriate locations so as to yield a representative assessment of the contamination situation". Also, it is stated that the removable contamination level may be determined by using an absorbent material to wipe the surface with moderate pressure (over $300 \mathrm{~cm}^{2}$ of surface area), and then measuring the activity on the wiping material. It may be assumed that the levels in Table 1.2-1 are not exceeded if the measured activity (per $\mathrm{cm}^{2}$ ) does not exceed 10 percent of those levels. For exclusive use shipments, as defined in 49 CFR 173.389(0) (1979), the removable contamination levels may not exceed 10 times the levels shown on Table 1.2-1. If such exclusive use shipments are made, a final radiation survey must be performed after each use. The results of this survey must indicate a radiation dose rate at any accessible surface of 0.5 millirem per hour or less, and removable surface contamination below the maximum permissible levels shown in Table 1.2-1 before the vehicle can be returned to service. 
TABLE 1.2-1 Current Removable Surface Contamination Limits for Transportation Containers(a)

Contaminant

Natural or Depleted Uranium and

Natural thorium:

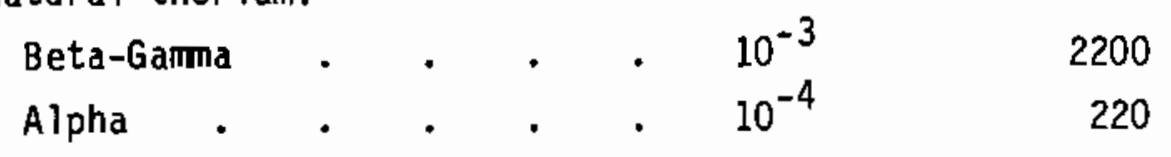

A11 Other Beta-Gamma Emitting

Radionuclides . . . . $10^{-4}$

220

All Other Alpha Emitting

Radionuclides . . . . $10^{-5}$

22

(a) 49 CFR 173.397 (1979).

(b) For exclusive use shipments, these levels may be increased by a factor of 10 .

\subsection{Application of Data}

The information contained in this report is designed to be used by the NRC in their review of current regulations. While we have had to make many assumptions in both the radiation dose and economic analyses, we have based these assumptions on current information obtained from both industry and the literature to obtain realistic yet conservative estimates.

The radiation dose evaluation contains a discussion of the exposure pathways, scenarios, models, and results obtained for exposures resulting from removable surface contamination on transportation containers. The potentially significant exposure pathways considered are ingestion, inhalation, and direct exposure. Radionuclides are selected for each category of container based on the maximum permissible concentration in air, $(M P C)_{a}$. In some cases, a comparison is made of doses between high 
and low toxicity radionuclides. The doses are calculated to "composite" workers, individuals, and population groups by summing the doses over all exposure pathways and scenarios. The resulting doses tend to be conservatively large since different individuals may be exposed by each pathway however, the results are believed to be valid for est imating collective doses. For the containers that may be transported as exclusive use shipments, only secondary exposure pathways to the public are considered. That is, a limited population group (of 10 people) is assumed to ultimately ingest a small fraction of the total surface contamination that remains on truck surfaces. Graphs of weighted total body dose versus contamination level are included. The results of an analys is of the potential dose impacts from decontamination of spent fuel casks and low-level radioactive waste drums are also plotted. From these plots the total collective doses to workers and the public associated with a full year of operation at a specific removable surface contamination limit can be calculated. This can be done by estimating the total dose per container at a given contamination level and multiplying by the total number of containers of a specific category shipped per year. In this manner, the relative impact of different surface contamination limits can be estimated and compared for each container category.

The economic cost analysis presents estimates of direct costs based on current industry estimates. Three basic contributors to direct costs are examined: 1) monitoring time costs, 2) instrumentation capital costs, and 3) decontamination costs. A primary cost component of monitoring is the amount of time required to analyze a sample. The amount of time depends upon the level of the background radiation, the specific activity of the radioactive isotopes, the types and energies of the radiation emitted, and the detector efficiency of the instrument used. Costs are estimated for various instrumentation and condition-specific scenarios. Instrumentation costs are developed from manufacturer price lists and estimates obtained from industry contacts. Decontamination 
costs are estimated for spent fuel casks and low-level waste drums and then added to the other direct cost factors to determine the total direct cost impacts of reducing allowable removable surface contamination limits. An estimate of the annual direct cost impacts of reduced removable surface contamination limits down to 10 percent or 1 percent of current limits $c$ an be made for each type of container. This can be done by multiplying the estimated additional cost to achieve a given limit (per container) times the number of containers shipped per year. This procedure will result in a rough estimate only since many assumptions have been made in support of the overall economic cost analysis.

The frequency distribution analysis determined removable surface contamination levels from hundreds of containers measured in the field during this study. The data, collected from shipping records and actual smear samples taken from containers being transported, was collected during field trips to representative industries. Both alpha and beta-gama data were collected for all four categories of containers considered. In order to quantify the amount of radiation detected over a given amount of time, a scaler was used instead of a count-rate (or dose-rate) meter. Contamination frequency distributions are given that relate the number of samples collected to the observed or reported removable surface contamination level. From the data we collected, it appears that only spent fuel casks currentiy have contamination levels that are frequently greater than $1 \%$ of the current limits. The number of spent fuel casks requiring further decontamination due to reduced limits, can be estimated from the percent of the casks in excess of the reduced limit and the number of shipments occurring per year.

By combining the results of the radiation dose evaluation, economic cost analysis, and frequency distribution analysis, predictions can be made of the overall impact of reducing removable surface contamination limits. For an assumed reduction in the limits, the number of containers shipped that are in excess of the reduced limit for each container category can result using the frequency distribution data. From this information and the dose-per- 
container estimates discussed in the radiation dose evaluation, estimates of the total dose reduction associated with the assumed reduced limit can be made. Estimates of the total cost impacts for the same reduced limit can result using the cost-per-container data. Thus, a comparison can be made of the estimated dose and cost impacts associated with an assumed reduction in the limits. Estimates of the overall dose and cost impacts made from the data contained in this report should be useful in reviewing the basis of current removable surface contamination limits and in preparing recommendations for future limits. 


\section{REFERENCES}

Comptroller General of the GAO. 1979. Report to the Congress of the United States. "Federal Actions are Needed to Improve Safety and Security of Nuclear Materials Tranpsoration". EMD-79-18, Washington D.C.

49 CFR 173.389(0). 1979. U.S. Code of Federal Regulations. Tit le 49 part 173.389(0), "Radioactive Materials; Definitions", Government Printing office, Washington, D.C.

49 CFR 173.397. 1979. U.S. Code of Federal Regulations. Tit le 49 Part 173.397, "Contamination Contro1", Government Printing Office, Washington, D.C. 



\section{GENERAL FINDINGS AND SUMMARY OF RESULTS}

The general findings and a summary of results obtained in this study of removable surface contamination on radioactive materials transportation containers are presented in this chapter. The categories of containers considered are for radiopharmaceutical, industrial source, nuclear fuel cycle material, and low-level radioactive waste shipment. Basic analysis is provided for radiation dose, economics, and contamination frequency. The principal findings and results given in this chapter are discussed in greater detail in Chapters 3 through 5 of this report.

\subsection{General Findings}

Based on our investigation and analysis of removable surface contamination on radioactive materials transportation containers, we have found that currently the radiation doses, costs, and contamination levels are all quite low. Reducing the limits by factors of 10 or 100 may have a cost impact without causing a significant savings in dose. When decontamination of a container surface is required, the total collective dose may actually increase since the additional dose to workers from the contents of the shipping containers during decontamination greatly exceeds the reduction in public dose.

On a per container basis at current Oepartment of Transportation (DOT) limits, the collective occupational and public weighted total body 50year committed dose equivalents for either alpha or beta-gamma contamination are all less than $3 \times 10^{-3}$ man-rem for all types of containers. This finding is based on the results of our radiation dose evaluation which attempted to obtain conservative, yet realistic, doses.

Direct economic costs are estimated by considering monitoring time, instrumentation equipment, and decontamination costs. Lowering the limits by factors of 10 or 100 would sharply increase these total direct costs. Additionally, indirect costs caused by delays in production or shipping schedules and further decontamination could add significantly to the total shipping 
cost. The largest direct cost element caused by reduced limits is to the monitoring time cost (labor), especially when alpha monitoring is required.

Surface contamination data collected in this study from about 500 containers of various types indicates that actual removable surface contamination levels are quite low. For all types of containers except spent fuel casks, our data indicates that these levels are generally less than 1\% of the current limit. The majority of spent fuel shipments (about 70\%) appear to have contamination levels less than $10 \%$ of the current limit. Spent fuel casks would require further decontamination efforts if the surface contamination limits are reduced.

The problem of spent fuel cask sweating does not appear to be a significant problem at current limits; however, due to of the lack of available data on this topic prediction of the impacts associated with reduced surface contamination limits is not possible.

\subsection{Summary of Results}

The principal results obtained during the radiation dose evaluation, economic cost analysis, and contamination frequency distribution analysis are discussed in the following sections. More detailed information about the specific methods and assumptions used to obtain these principal results are given in the chapters that follow.

\subsubsection{Radiation Dose Evaluation}

The potentially significant exposure pathways considered include direct external exposure and internal exposure via ingestion, and inhalation. Calculations indicated that direct exposure (from surface contamination only) was a minor contributor to the total dose, and it is not reported in the total dose tables or in the results presented here. Ingestion doses are calculated based on assumptions that compare with those made 
in previous studies. These assumptions deal with the fraction of the total removable surface contamination that can be ingested by workers and members of the public.

Inhalation of contaminants is assumed to result when contamination becomes airborne by the mechanisms of resuspension, incineration of container materials, and inhalation directly from contamination transferred to the hands. Since data on the physical and chemical characteristics of airborne contamination from containers is currently unavailable, assumptions are made so that radiation dose can be estimated.

Reference transportation containers are defined for each of four categories of containers considered. Reference radionuclides are selected for each container category based on the maximum permissible concentrations in air, (MPC) $)_{a}$. In some cases a comparison is made between the most restrictive radionuclide and a less restrictive radionuclide to demonstrate a possible range of dose impacts. For spent nuclear fuel, reference beta-gamma and alpha mixtures are defined for use in the dose calculations.

First-year radiation dose equivalents and fifty-year comitted radiation dose equivalents are calculated for "composite" workers, individuals, and population groups. These composite persons are defined in an attempt to obtain realistic yet conservative radiation dose estimates. They are calculated by summing the doses over all pathways and scenarios, even though different individuals may be exposed by each pathway. For ease of comparison, weighted total body doses are reported for the composite workers, individuals, and population groups defined for each container category.

The radiation doses from optional exposure pathways are considered by applying weighting factors. For example, we have assumed that $5 \%$ of empty radiopharmaceutical containers are released to the public, 55\% are 
incinerated, and $40 \%$ are disposed of as low-level radioactive waste. Thus, total doses are found by suming the weighted fractional components of each optional use.

The results of this study are summarized graphically for each category of containers in Section 3.6 of Chapter 3. An example of these summary figures is shown in Figure 2.2-1 for low-level radioactive waste. The dose relationships for ${ }^{239} \mathrm{Pu},{ }^{90} \mathrm{Sr},{ }^{129} \mathrm{I}$, and ${ }^{60} \mathrm{Co}$ are shown to demonstrate a range of radionuclide dependent doses. Collective doses to both workers and a limited population group are shown to be less than $3 \times 10^{-3}$ man-rem per container shipped at the current DOT Limits. For comparison, calculations are made for two beta emitters, ${ }^{90} \mathrm{Sr}$ and ${ }^{129} \mathrm{I}$. From the results shown in Figure 2.2-1, both the weighted total body occupational dose and the public dose for ${ }^{90} \mathrm{Sr}$ are larger than the corresponding doses from ${ }^{129} \mathrm{I}$. Complete results for the other categories of containers and their exposure scenarios are given in Chapter 3.

Several factors influence the analysis of radiation doses from decontamination, including: the exposure rate to workers from the contents of the container being decontaminated, the radionuclides considered in the surface contamination dose calculations, the surface contamination level at the start of decontamination, and the decontamination factor associated with the technique used. The impacts of these factors on the total collective radiation dose (in man-rem) from decontamination of spent fuel casks and low-level radioactive waste drums are shown in Chapter 3 . An example of the relative impacts of several of these factors are shown in Figure 2.2-2. This figure also shows the occupational and public components of the total dose. For the data shown in Figure 2.2-2, the optimum point between total dose and decontamination time is found where minimums in the curves occur. The only minimum that occurs is for the lowest direct exposure rate $(1 \mathrm{mrem} / \mathrm{h})$. Thus, no total dose reduction occurs for higher direct exposure rates. A decision on the importance of surface decontamination should be made by weighing an increase in occupational exposure against the potential savings in public dose. 


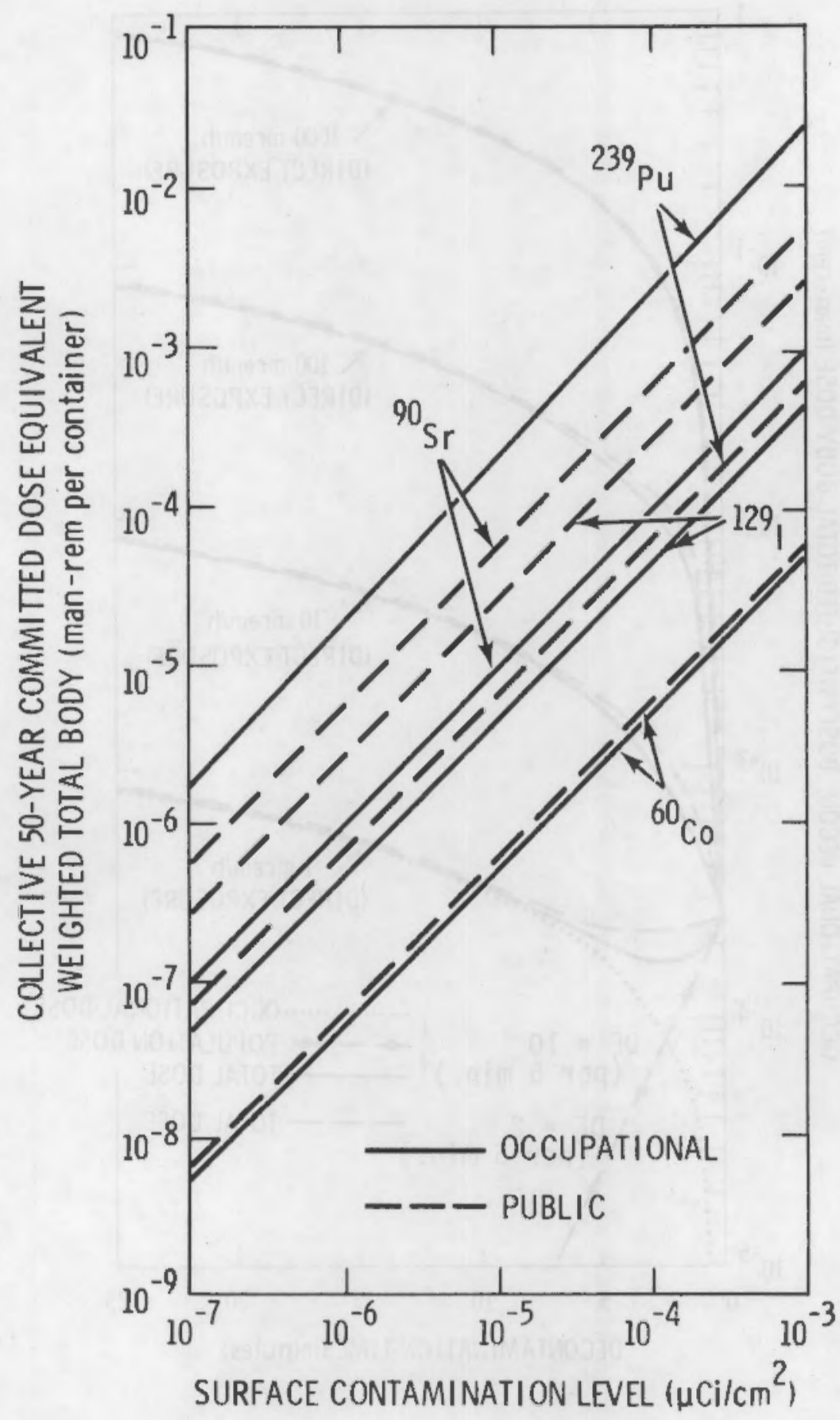

FIGURE 2.2-1 Example Collective Doses from Surface Contamination on Low-Level Radioactive Waste Transportation Containers 


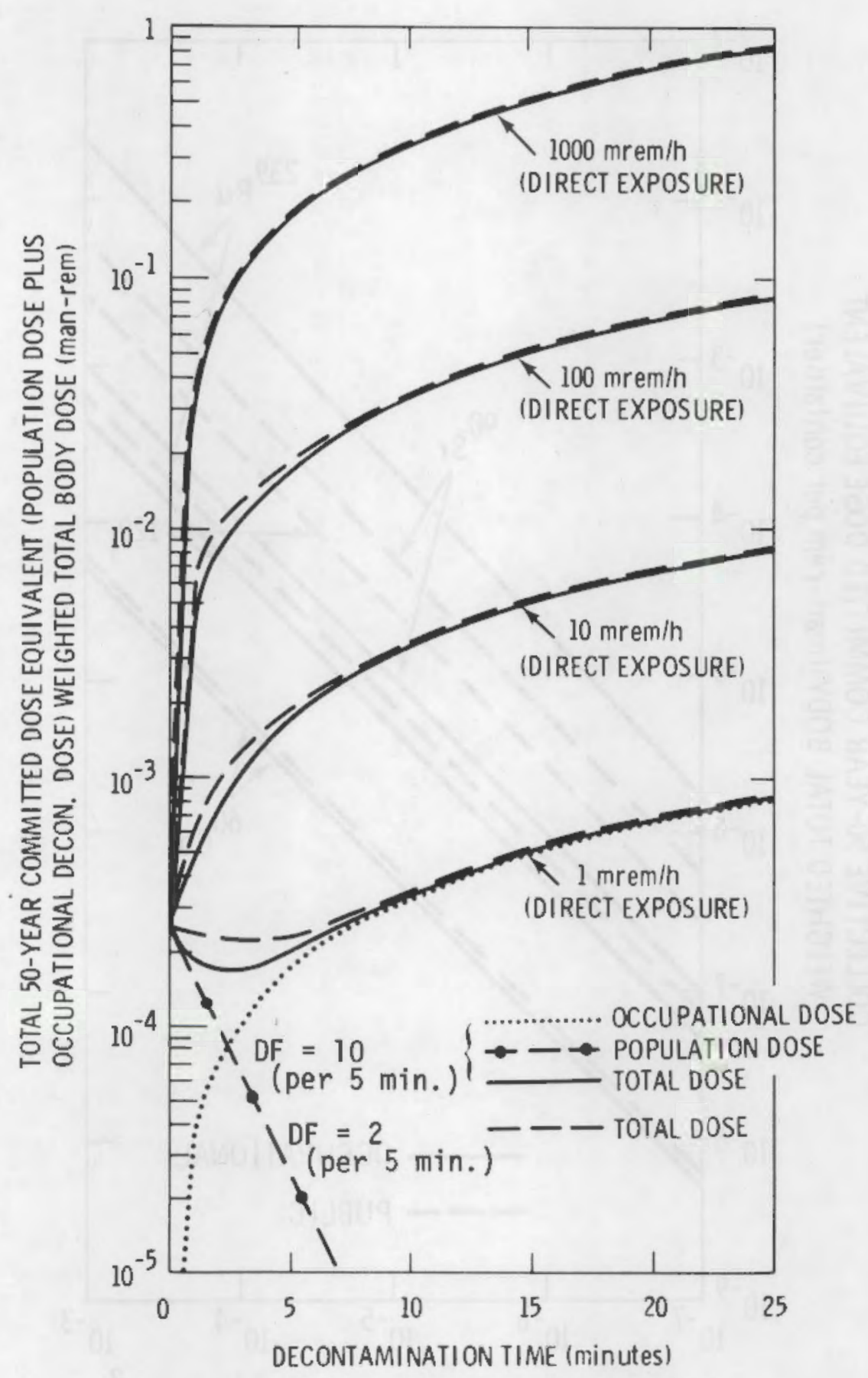

FIGURE 2.2-2 Example Total Dose Versus Decontamination Time for ${ }_{129}$ I Starting at a Level of $10^{-4} \mu \mathrm{Ci} / \mathrm{cm}^{2}$ - Low Level Radioactive Waste Transportation Containers 
All of the doses calculated and discussed in Chapter 3 are quite small on a per-container basis. The total dose associated with a full year of operation at a specific surface contamination limit can be calculated for each type of container. This can be done by estimating the total dose per container at a given level (from the curves in Section 3.6) and multiplying by the number of containers of a specific category shipped in a year. In this manner, the relative impact of different surface contamination 1 imits can be estimated for each container category.

\subsubsection{Economic Cost Analysis}

The purpose of the economic cost analysis is to provide information on the economic costs of reducing the removable surface contamination limits for transportation containers so that a general comparison between economic costs and health benefits is possible. The health benefits to be gained from reducing removable surface contamination limits are not measured in an economic sense in this study. Attaching a dollar value to health benefits is a complex problem that is beyond the scope of our analysis. The information summarized in this section is presented in detail in Chapter 4.

The direct economic costs of reducing removable surface contamination limits are divided into three categories: monitoring-time costs, instrumentation capital costs, and decontamination costs. Direct cost measurements are estimated on the basis of quantitative information obtained from industrial representatives and from theoretical cost modeling. Monitoring time costs are the largest single direct cost component since the decontamination costs per container have been weighted by the frequency of decontamination as reported by our industry contacts.

When the direct cost impacts are summed for the three cost categories, assuming both alpha and beta-gamma monitoring are done for each container, the total cost impacts are found. The estimated costs incurred by reducint the removable surface contamination 1 imits by factors of 10 and 100 are shown in Figure 2.2-3. These are direct costs associated with demonstrating compliance and are independent of existing contamination levels. Based on a monitoring cost of $\$ 27$ per hour, the total cost impacts resulting 


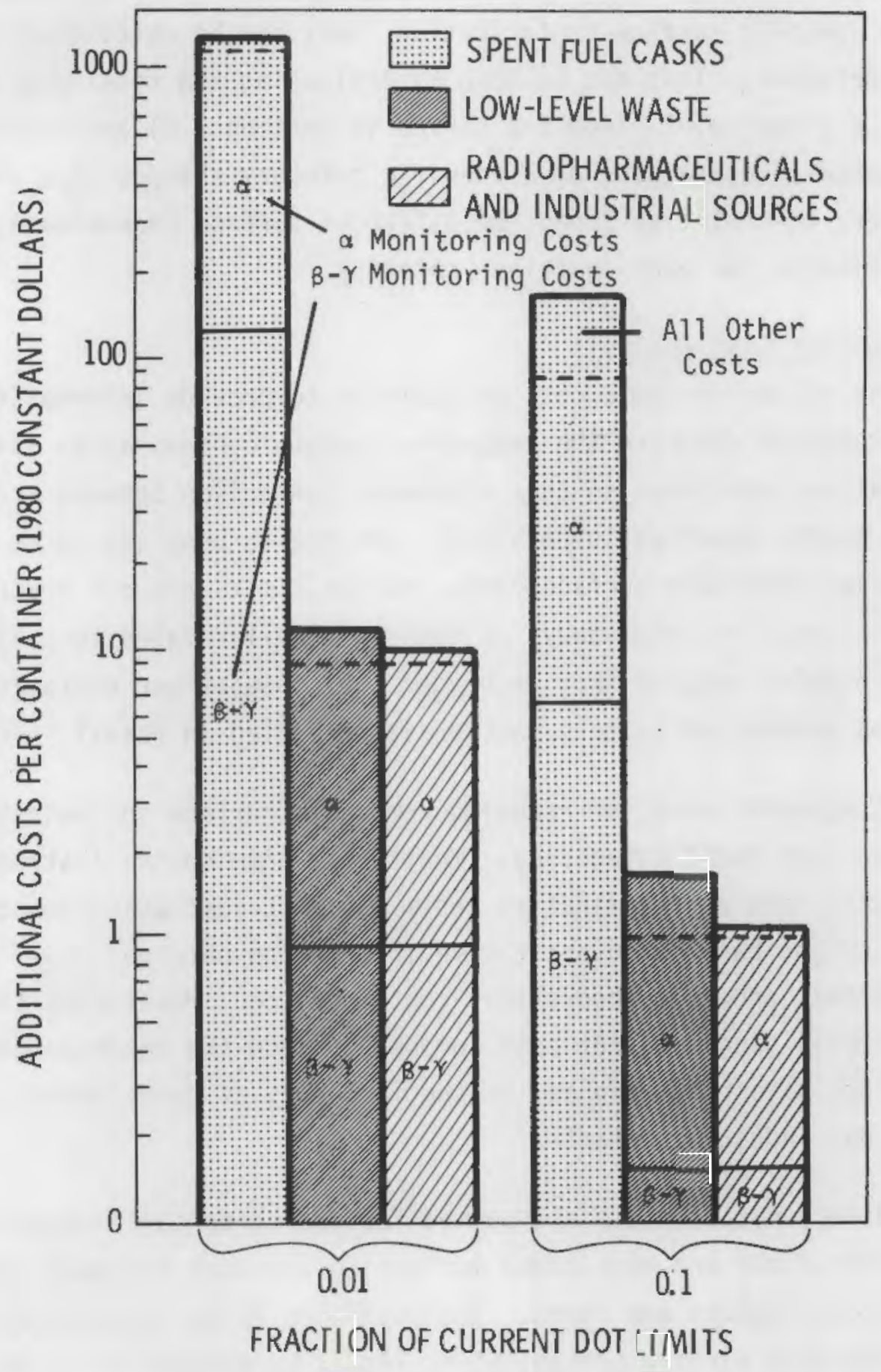

FIGURE 2.2-3 Estimated Economic Costs for Reducing Removable Surface Contamination Limits 
from limits 10 times below current limits are about $\$ 1.10$ per container for radiopharmaceutical and industrial source shipments, about $\$ 1.60$ per drum for waste shipments, and about $\$ 160$ per cask for spent fuel casks. The total cost impacts at 100 times below current limits are about $\$ 9.40$ per container for radiopharmaceuticals and industrial source shipments, about $\$ 10.50$ per drum for low-level waste shipments, and about $\$ 1330$ per cask for spent fuel casks. The largest cost element in these totals is the cost of alpha radiation monitoring.

The effects of reduced limits on vehicle monitoring and decontamination costs were also estimated. At $\$ 30$ per hour for decontamination, the total cost impact weighted by the frequency of decontamination at 10 times below current limits would be about $\$ 5.40$ per shipment for radiopharmaceuticals and industrial source shipments, about $\$ 25$ per shipment for waste shipments and about $\$ 115$ per shipment for spent fuel casks. At 100 times below current limits, the weighted costs are about $\$ 47$ per shipment for radiopharmaceuticals and industrial source shipments, about $\$ 213$ per shipment for lowlevel waste shipments and $\$ 920$ per shipment for spent fuel casks.

An estimate of the annual direct cost impacts of reduced removable surface contamination limits can be made for each type of container. This can be done by multiplying the estimated additional cost to achieve a given limit (per container) times the number of containers shipped per year. This procedure will result in a rough estimate only since many assumptions have been made in support of the overall economic cost analysis. Further details about the economic analysis for specific types of containers are found in Chapter 4.

All of the industrial representatives contacted believed that the indirect costs of reduced contamination limits would probably exceed the direct costs. Some of the indirect costs would include delays in production and distribution schedules, increased transit costs because of longer waits for monitoring and decontamination, and increased administrative costs because of additional regulatory actions. 


\subsubsection{Contamination Frequency Distributions}

Information was collected from industry representatives on the present levels of removable surface contamination for the four categories of containers considered. Both shipping records and measurements were used to produce data relating the number of smears to the measured or reported contamination leve1. This section contains a summary of the data presented in Chapter 5, which also details the instrumentation, procedures, and results obtained in this study.

Data from a total of 498 shipping containers were collected during this study including data from 252 radiopharmaceutical containers, 43 industrial source containers, 40 uranium containers ( $\mathrm{UF}_{6}$ or $\mathrm{U}_{3} \mathrm{O}_{8}$ ), 48 spent fuel casks, and 116 low-level waste drums. Both the beta-gamma and alpha removable surface contamination levels for radiopharmaceutical, industrial source, uranium, and low-level waste shipments were all less than $1 \%$ of the current DOT limits. Only the data for spent fuel casks gave a frequency distribution of average surface contamination levels in a range greater than $1 \%$ of the current limits.

Examples of the frequency distributions collected in this study are shown in Figures 2.2-4 and 2.2-5 for radiophasmaceuticals. These plots show the number of smears versus the removable surface contamination level in disintegrations per second per $\mathrm{cm}^{2}$ of surface area for alpha and beta-gamma contamination. All of the measured data in these example figures are significantly below the current DOT maximum permissible level. Similar figures for the other categories of containers and further details are found in Chapter 5.

From our data it appears that all categories of containers, except for spent fuel casks, further container decontamination will be quite rare if the reduction in limits does not go below $1 \%$ of the current limits. After surface decontamination, the removable surface contamination associated with a spent fuel cask may increase by a process known as sweating. Current information indicates that the problem has been reduced in newer generations of spent fuel casks and with administrative procedures. Because of the lack of quantitative data on sweating, we cannot predict the impacts associated with reduced surface contamination limits. 


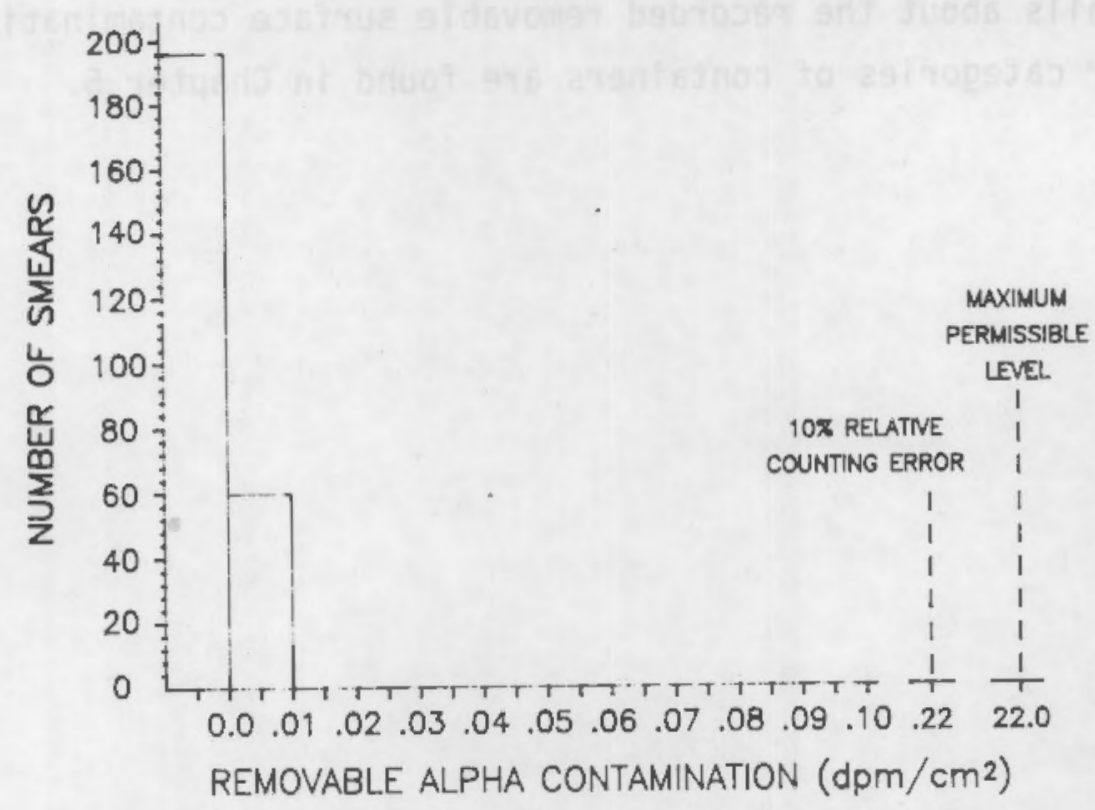

FIGURE 2.2-4. Frequency Distribution for Radiopharmaceuticals Alpha Contamination

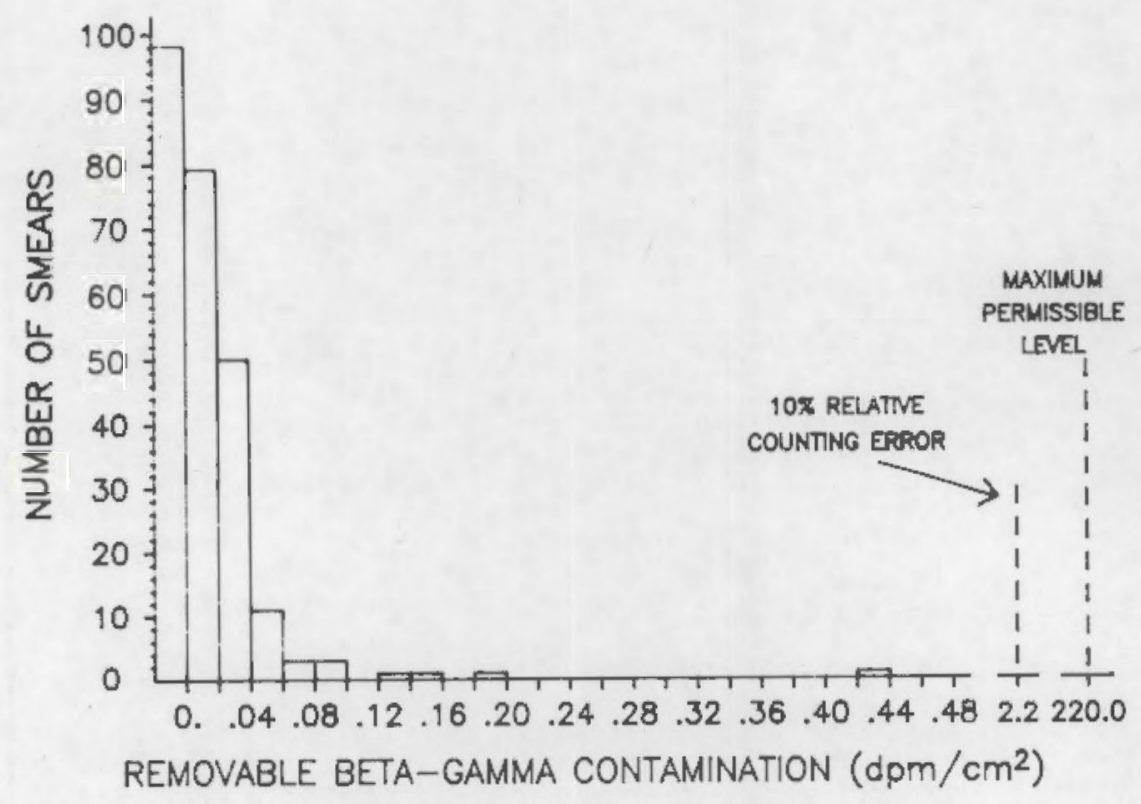

FIGURE 2.2-5. Frequency Distribution for Radiopharmaceuticals Beta-Gamma Contamination 
Further details about the recorded removable surface contamination levels for all four categories of containers are found in Chapter 5. 


\section{RADIATION DOSE EVALUATION}

This chapter contains a discussion of the pathways, models, scenarios and results obtained for the radiation dose evaluation of the radioactive surface contamination associated with containers used to transport radioactive materials. Radiation exposure pathways and dose scenarios are developed based on information obtained from the literature and from industry sources. Computer models used to calculate the radiation doses are described along with relevant information about the uptake and retention of radionuclides from the exposures pathways. Separate sections contain discussions of the radionuclides, exposure scenarios, calculated doses and summary of results for each category of transportation container considered in this study.

\subsection{Radiation Exposure Pathways and Dose Models}

To estimate the radiation exposure associated with removable surface contamination on containers used to transport radioactive materials, consideration is given to the pathways by which workers or the public may be exposed. The potentially significant radiation exposure pathways considered in this study are: ingestion, inhalation, and direct exposure. The radiation dosimetry models used for these pathways are based on the recommendations of the ICRP $(1959 ; 1966 ; 1966 a)$. These models are used in computer programs designed to simulate the environmental behavior of radionuclides and to calculate pathway-specific radiation doses. Each computer program used in this study has been separately documented and used in other studies conducted by Battelle (Schneider and Jenkins 1977; Oak et al. 1980; Murphy and Holter 1980). The computer programs access various standardized data libraries that contain pathway-specific data. Both first-year radiation dose equivalents and fifty-year committed radiation dose equivalents are calculated for this study using the computer programs referenced in Section 3.1 and the radiation dose scenarios outlined in Section 3.3. The organs of references, for which radiation doses are calculated for this study are: bone, lung, thyroid and weighted total body using the weighting factors 
defined by the ICRP (1977). In an attempt to obtain realistic yet conservative radiation dose estimates, we have defined "composite" workers, individuals, and population groups. The radiation doses to these persons are calculated by summing the doses over all exposure pathways and scenarios. This process results in a conservatively large dose, or composite dose, since different individuals may be exposed by each pathway. Also, we have weighted the calculated doses from optional exposure scenarios, such as incineration or release to the public of used container materials, to account for the disposition of empty containers by several alternative methods. Estimates of the total occupational dose are made by multiplying the dose to an individual worker by the size of the work force. The work force is defined to be four composite workers for each container category. By this method, we have assumed that all workers are equally exposed. This is done to obtain realistic averages of individual workers who may receive either larger or smaller doses. Estimates of the total number of people in a public population group are made for each exposure pathway and container category.

The following sections contain discussions of the assumptions made about each of these exposure pathways, the radiation dose models, and computer programs used to calculate radiation doses.

\subsubsection{Direct Ingestion}

Ingestion of radioactive surface contamination can occur when surface contamination is transferred from a surface to hands, foodstuffs, cigarettes, or other items that enter the mouth. Previous dose evaluations of the ingestion of surface contamination have been directed toward chronic occupational exposure situations. A review of previous work indicates that no quantitative data are available for relating surface contamination levels to the rate of ingestion. Because of the lack of data, previous studies have relied on assumed ingestion rates to perform radiation dose evaluations. The specific assumptions used in these previous dose evaluations are listed in Table 3.1-1. 


\section{TABLE 3.1-1. Reported Surface Contamination Ingestion Scenarios}

\begin{tabular}{|c|c|c|c|}
\hline $\begin{array}{l}\text { Author and } \\
\text { Reference }(a)\end{array}$ & Scenario & Ingestion Rate & Comments \\
\hline (Dunster 1962) & $\begin{array}{l}\text { Maximum permissible } \\
\text { levels of skin con- } \\
\text { tamination }\end{array}$ & $10^{-3} \mathrm{~m}^{2} /$ day & $\begin{array}{l}\text { Chronic ingestion of }(\mathrm{MPC})_{W} \text { values of } \\
226 \mathrm{Ra}, 90 \mathrm{Sr} \text {, and } 210 \mathrm{~Pb} \text { to derive } \\
\text { permissible levels of skin contamination }\end{array}$ \\
\hline $\begin{array}{l}\text { (Gibson and } \\
\text { Wrixon 1979) }\end{array}$ & $\begin{array}{l}\text { Derived working limits } \\
\text { for surface contami- } \\
\text { nation by low-toxicity } \\
\text { radionuclides }\end{array}$ & $10^{-3} \mathrm{~m}^{2} /$ day & $\begin{array}{l}\text { Chronic ingestion. No data available to } \\
\text { improve upon Dunster's model - }(\mathrm{MPC})_{W} \text { analys is }\end{array}$ \\
\hline (Healy 1971) & $\begin{array}{l}\text { Surface contamination } \\
\text { decision levels }\end{array}$ & $10^{-4} \mathrm{~m}^{2} / \mathrm{h}(8 \mathrm{~h})$ & $\begin{array}{l}\text { Chronic ingestion during } 8 \mathrm{hrs} \text { for workers, } \\
24 \mathrm{hrs} \text { for members of the public. These are } \\
\text { arbitrary assumptions in an effort to account } \\
\text { for presumed higher intake by children, i.e., } \\
2.4 \times 10^{-3} \mathrm{~m}^{2} / \text { day. }\end{array}$ \\
\hline
\end{tabular}

(a) References are listed at the end of this section. 
Dunster (1962, p. 3) stated that in practice it is convenient to measure contamination on each hand, and thus it is desirable to express limits for hand contamination in terms of the total activity per hand. He assumed that the average hand has an approximate surface area of $3.0 \times 10^{-2} \mathrm{~m}^{2}$ ( $\mathrm{palm}$ and back), and that about $3.0 \times 10^{-3} \mathrm{~m}^{2}$ could contain more concentrated radioactivity levels. This smaller area is approximately the area associated with the fingertips and edges of the palm. Dunster (p. 4) further assumed that $10^{-3} \mathrm{~m}^{2}$ of surface contamination could be ingested per day by the average worker.

Healy $(1971$, p. 23$)$ modified the ingestion model by assuming that $10^{-4} \mathrm{~m}^{2}$ of surface contamination could be taken into the mouth per hour. Thus, for workers $8.0 \times 10^{-4} \mathrm{~m}^{2} /$ day and for the public $2.4 \times 10^{-3} \mathrm{~m}^{2} /$ day of surface contamination were assumed to be ingested. The higher ingestion rate for the public is presumed to allow for higher intake by children.

Gibson and Wrixon (1979) discussed Dunster's method of calculating ingestion doses to workers. Dunster had considered only the most toxic radionuclides (e.g., ${ }^{90} \mathrm{Sr},{ }^{210} \mathrm{~Pb},{ }^{226} \mathrm{Ra}$, and ${ }^{239} \mathrm{Pu}$ )." Using Dunster's method and assumptions, Gibson and Wrixon calculated doses for some of the more commonly used low-toxicity radionuclides. They stated that for specialized uses of low-toxicity radionuclides, less restrictive surface contamination limits should apply.

Since these previous studies were designed to model chronic exposure resulting from contact with uniformly contaminated surfaces, and since the results of this study are calculated on a dose-per-container basis, modifications to the previous models are required. To calculate ingestion doses for the exposure scenarios of this study the following assumptions are made:

- For workers, a total of $5 \times 10^{-5} \mathrm{~m}^{2}$ of surface contamination is ingested per container per worker. This value compares to a 30

- minute exposure in the Healy $(1971$, p. 23) study. 
- For containers that are released to the public after the contents have been removed, $1.0 \times 10^{-3} \mathrm{~m}^{2}$ of total container surface contamination is assumed to be ingested by an individual in contact with the container. The ingestion by the public assumes an individual who handles the container 20 times more than a worker, and this compares to 10 hours of exposure in the Healy (1971) study. NOTE: This amount of ingestion also accounts for the contamination that may be transferred to a truck surface and ingested by an individual by a secondary transfer to items entering the mouth. Also, the amount of ingestion is less than the surface area of the finger tips of both hands as defined in the Dunster $(1962$, p. 3) study.

Dose factors for direct ingestion of surface contamination are calculated using the ARRRG computer program (Napier et. al. 1980). It was designed to calculate internal dose to specific organs from liquid releases of radionuclides to the environment. Modifications to the input of the ARRRG program permit calculation of ingestion dose factors relating to the ingestion scenarios defined in this study.

\subsubsection{Inhalation}

Inhalation of radioactive surface contamination can occur when there is a mechanism that creates an airborne concentration. For this study, three mechanisms of creating airborne contamination for inhalation are reviewed: resuspension from container surfaces, incineration of used container materials, and inhalation directly from hands. Inhalation dose factors are calculated using the DACRIN computer program (Houston, Strenge and Watson 1976) and these air concentrations. The DACRIN computer program is based on the Task Group on Lung Dynamics Model (ICRP 1966) for inhalation of radionuclides. Once radionuclides are transferred from the lung to the bloodstream, the dose to organs other than the lung is calculated using a single exponential retention function. 
Data on the physical and chemical characteristics of airborne contamination from transportation containers is currently unavailable. Thus, assumptions are made so that radiation dose estimates can be calculated. For this study, a particle size of $1 \mu \mathrm{m}$ activity median aerodynamic diameter (AMAD) is assumed. Radionuclides are also classified by the rate at which they are dissolved into body fluids in the lung after inhalation. Three classifications are generally used: Class D materials, with a maximum biological half-life of less than 1 day; Class $W$ material, with a maximum biological half-life ranging from a few days to a few months; and Class $Y$ materials, with a maximum biological halflife of from 6 months to a few years (ICRP 1966). For this study, soluble classifications (either $D$ or $W$ ) are assumed for all radionuclides and for all organs except for the lungs. Insoluble classifications (either $W$ or $Y$ ) are assumed for the lungs. The solubility classes for various elements are shown in Table 3.1-2 for all other body organs and for the lungs.

The following sections contain detailed discussions of the assumptions made in calculating air concentrations from resuspension, incineration, and inhalation directly from hands.

\subsubsection{Resuspension}

Air concentrations of radioactive particulates can be determined by balancing the effects of resuspension with redeposition and removal factors for specific situations. A literature review of data on resuspension indicates that resuspension factors or rates (summarized in Table 3.1-3) can vary over a wide range of measured values. This range strongly suggests that resuspension is a complex function of several condition-specific parameters. Since it is not within the scope of this study to perform actual resuspension measurements, resuspension rate assumptions are made based on these literature values. Healy (1971, p. 79) concluded that in reasonably well ventilated buildings redeposition forces are small compared to room ventilation for reducing the air concentration of respirable particles. Thus, the air concentration in a 
TABLE 3.1-2. Solubility Classes for Elements from Literature Sources

Solubility Class (a)

Element

(a11 other body organs/lungs)

Reference $^{(b)}$

Hydrogen $(H)$

$D / D$

ICRP $1966 \mathrm{a}$

Carbon (C)

$D / D$

ICRP 1966a

Phosphorus (P)

$D / W$

ICRP 1966 a

Chromium ( $\mathrm{Cr}$ )

$W / Y$

ICRP 1966a

Manganese (Nn)

$D / W$

Killoush 1978

Iron ( $\mathrm{Fe}$ )

$W / Y$

Killoush 1978

Cobalt (Co)

$W / Y$

Killoush 1978

Nickel (Ni)

$W / W$

ICRP 1966a

Zinc (Zn)

$W / Y$

ICRP 1966a

Strontium ( $\mathrm{Sr}$ )

$D / Y$

Killoush 1978

Yttrium ( $Y$ )

$D / Y$

Killoush 1978

Zirconium (Zr)

$W / Y$

Killoush 1978

Niobium (Nb)

$W / Y$

Killoush 1978

Technetium (Te)

$D / W$

Killoush 1978

Ruthenium (Ru)

$Y / Y$

Killoush 1978

Iodine (I)

$D / D$

Killoush 1978

Cesium (Cs)

$D / D$

Killoush 1978

Barium (Ba)

$D / W$

ICRP 1966a

Lanthanum ( $L a$ )

$W / Y$

ICRP 1966a

Cerium (Ce)

$W / Y$

ICRP 1966a

(a) Solubility classes are for use in the ICRP Task Group Lung Model. (b) References are shown at the end of this chapter.

room, $\mathrm{x}$ in $\mathrm{Ci} / \mathrm{m}^{3}$, can be expressed as a function of the resuspension rate and room ventilation rate by (Healy 1971, p. 80 ):

$$
x=\frac{f A \Omega}{V n}
$$




\section{TABLE 3.1-3. Reported Resuspension Information}

\begin{tabular}{|c|c|c|c|}
\hline $\begin{array}{l}\text { Condit ion, Authpr } \\
\text { and Reference }\end{array}$ & $\begin{array}{l}\text { Resuspended } \\
\text { Contaminant and Form }\end{array}$ & Factor or Rate Range & Coments \\
\hline \multicolumn{4}{|l|}{ Wind Stress on: } \\
\hline \multicolumn{4}{|l|}{ Bare Soil } \\
\hline (Stewart 1964) & 91Y Aqueous Cnloride & $8 \times 10^{-9}$ to $2 \times 10^{-11}\left(\mathrm{~m}^{-1}\right)$ & $\begin{array}{l}\text { Various particle sizes; various } \\
\text { surface areas }\end{array}$ \\
\hline (Steward 1964) & $210 p_{0}$ as $0 x$ ide & $1 \times 10^{-7}$ to $9 \times 10^{-8}\left(\mathrm{~m}^{-1}\right)$ & $\begin{array}{l}\text { Disturbed soil; various surface } \\
\text { concentrations }\end{array}$ \\
\hline (Stexard 1964) & $\mathrm{U}_{3} \mathrm{O}_{8}$ & $5 \times 10^{-7}$ to $9 \times 10^{-8}\left(\mathrm{~m}^{-1}\right)$ & Concrete paving stones \\
\hline $\begin{array}{l}\text { (Mishima and } \\
\text { Schwend iman 1972) }\end{array}$ & $\mathrm{VO}_{2}$ Powder & $1.6 \times 10^{-4}$ to $1.2 \times 10^{-4}\left(\mathrm{~h}^{-1}\right)$ & $\begin{array}{l}\text { Accidental fire conditions of } \\
\text { respirable size only; various wind } \\
\text { speed }\end{array}$ \\
\hline \multicolumn{4}{|l|}{ Vegetation } \\
\hline (Healy and Fuquay 1959) & Fluorescent Powder & $2.9 \times 10^{-8}$ to $6.0 \times 10^{-7}\left(\mathrm{~m}^{-1}\right)$ & $\begin{array}{l}\text { Various concentrations; various } \\
\text { wind speeds }\end{array}$ \\
\hline $\begin{array}{l}\text { (Mishima and } \\
\text { Schwend iman } 1972\end{array}$ & $\mathrm{UO}_{2}$ Powder & $5.9 \times 10^{-5}$ to $7.0 \times 10^{-7}\left(n^{-1}\right)$ & $\begin{array}{l}\text { Accidental fire conditions of } \\
\text { respirable size only; various wind } \\
\text { speeds }\end{array}$ \\
\hline (Sehmel and Lloyd 1976) & Calcium Molybdate & $110^{-8}$ to $1 \times 10^{-10}\left(\mathrm{sec}^{-1}\right)$ & As a function of wind speed \\
\hline (Steward 1964) & $\mathrm{U}_{3} \mathrm{O}_{8}$ & $5 \times 10^{-5}$ to $3 \times 10^{-8}\left(m^{-1}\right)$ & Coarse desert grass \\
\hline (Sehmel 1974) & $2 n s$ & $3.4 \times 10^{-8}\left(\sec ^{-1}\right)$ & Freshly deposited \\
\hline (Ansaugh 1974) & Pu & $2.7 \times 10^{-12}$ to $4.8 \times 10^{-10}\left(\mathrm{sec}^{-1}\right)$ & $\begin{array}{l}10 \pi \text { vegetation cover; various wind } \\
\text { speeds }\end{array}$ \\
\hline \multicolumn{4}{|l|}{ Mechanical Mixing: } \\
\hline Sţewart 1964) & Pu & $1.5 \times 10^{-6}$ to $3.0 \times 10^{-4}\left(\mathrm{~m}^{-1}\right)$ & Dust Created by Pedestrians \\
\hline (Sehme) 1976) & Zns & $1 \times 10^{-5}$ to $2 \times 10^{-4}$ (fraction per pass) & $\begin{array}{l}\text { Various truck speeds in cheatgrass } \\
\text { area }\end{array}$ \\
\hline (Sehmel 1974) & $2 \mathrm{~ns}$ & $4.8 \times 10^{-5} 1.1 \times 10^{-2}$ (fraction per pass) & $\begin{array}{l}\text { Yarious car speeds on asphalt } \\
\text { roads }\end{array}$ \\
\hline (Milham 1975) & Environmental $\mathrm{Pu}$ & $3 \times 10^{-9}$ to $1 \times 10^{-6}\left(\sec ^{-1}\right)$ & $\begin{array}{l}\text { From various farming activities at } \\
\text { Savannah River }\end{array}$ \\
\hline (Healy 1971) & $\mathrm{PuO}_{2}$ in Floors & $1 \times 10^{-6}$ to $5 \times 10^{-3}\left(\mathrm{~h}^{-1}\right)$ & $\begin{array}{l}\text { Quiet through vigorous activity on } \\
\text { various floor surfaces }\end{array}$ \\
\hline
\end{tabular}

(a) References are listed at the end of this section. 
where:

$f$ the resuspension rate, $h^{-1}$

A - the area of the package from which resuspension occurs, $m^{2}$

$\Omega$ - the surface contamination level, $\mathrm{Ci} / \mathrm{m}^{2}$

$v$ - the volume of air in the room, $\mathrm{m}^{3}$

$n$ - the rate of room air exchange, $h^{-1}$.

(Note: $\frac{X}{\Omega}=K$, the resuspension factor, $\mathrm{m}^{-1}$ )

To calculate air concentrations from resuspension for the inhalation dose scenarios of this study, the following assumptions are made:

- The average resuspension rate equals $3 \times 10^{-4} \mathrm{~h}^{-1}$ (Healy 1971, p. 32).

- The shipping or receiving room containing the transportation container is $10 \times 10 \times 2.4 \mathrm{~m}$ with a total air volume of $240 \mathrm{~m}^{3}$.

- The room ventilation rate is 2 air exchanges per hour respresenting a reasonably air-tight room with closed windows and doors.

- The dimensions of the reference closed transport vehicle are $12 \times 2.4 \times 2.4 \mathrm{~m}$ with a total volume of $69 \mathrm{~m}^{3}$ (Colton and Emerson 1979 , p. 3).

- The ventilation rate of the open truck during cargo loading or unloading operations is 5 air exchanges per hour.

- The workers are exposed for a total of 30 minutes per worker per container in both the shipping room and the closed transport vehicle (for consistency with the ingestion models of this study).

- The individual in the public is exposed to released container material 10 hours (for consistency with the ingestion models of this study).

- A room in a private family dwelling is assumed to be $5 \times 3 \times 2.4 \mathrm{~m}$ with a total air volume of $36 \mathrm{~m}^{3}$. 


\subsubsection{Incineration}

Disposable containers used to transport some types of radioactive materials, such as radiopharmaceuticals, could be incinerated after use. Incineration of used containers leads to a short-term airborne release of radioactive materials. The atmospheric diffusion model for calculating airborne concentrations downwind is discussed in Regulatory Guide 1.3 (U.S. Atomic Energy Commission 1974). For atmospheric diffusion from a ground-level point source release the air concentration is given by:

$$
x=\frac{Q^{\prime}}{\pi u \sigma_{y} \sigma_{z}}
$$

where:

$$
\begin{aligned}
& X \text { - the short-term average centerline ground-level air } \\
& \text { concentration, } \mathrm{C} i / \mathrm{m}
\end{aligned}
$$

(Note: $X / Q^{\prime}$ the diffusion factor, $\mathrm{sec} / \mathrm{m}^{3}$ )

Both $\sigma_{y}$ and $\sigma_{z}$ are found in a publication by Gifford (1961 p. 48). For short-term releases, less than $8 \mathrm{hr}$, Pasquill Type $\mathrm{F}$ conditions with $1 \mathrm{~m} / \mathrm{sec}$ windspeed in a uniform direction are used. Graphical solutions of the diffusion factor $X / Q^{\prime}$ value for the maximum-exposed individual are calculated using a building-wake model (Slade 1968). Assuming complete reflection of the plume by the ground plane, the ground level centerline air concentration from a ground-level release is calculated by the building-wake equation:

$$
X=Q^{\prime}\left(\pi \Sigma_{y} \Sigma_{z} \bar{u}\right)^{-1}
$$


where:

$x$ - the short-term average centerline ground-level air concentration, $\mathrm{Ci} / \mathrm{m}^{3}$

Q' - the rate of release from the source, corrected for decay during transit to the exposure point, $\mathrm{Ci} / \mathrm{sec}$

$\bar{u} \bullet$ the average ground-level wind speed in the direction of travel, $\mathrm{m} / \mathrm{s}$

$\Sigma_{y}, \Sigma_{z} \bullet$ the building-wake diffusion coefficients, in meters, calculated by:

$$
\begin{aligned}
& \Sigma_{y}=\left(C A / \pi+\sigma_{y}^{2}\right) 1 / 2 \\
& \Sigma_{z}=\left(C A / \pi+\sigma_{z}^{2}\right)^{1 / 2}
\end{aligned}
$$

where:

c - a factor estimating the relation of the cross-sectional area to pressure wakes ( 0.5 for this study)

$\sigma_{y} \bullet$ the crosswind lateral standard deviation of the cloud concentration, $m$

$\sigma_{z} \bullet$ the crosswind vertical standard deviation of the cloud concentration, m.

Note: The limit on $\Sigma_{y}$ and $\Sigma_{z}$ is: $\Sigma_{y} \Sigma_{z} \leq 3 \sigma_{y} \sigma_{z}$

Minimum values of $\sigma_{y}$ and $\sigma_{z}$ of $\sqrt{A / 6}$ are assumed for this study.

Using Equation 3.3, Pasquill Type $F$ centerline diffusion factors calculated for various distances and selected release source cross-sectional areas are shown in Figure 3.1-1. . At about $500 \mathrm{~m}$ downwind, the curves for $A \leq 50 \mathrm{~m}^{2}$ converge. At distances close to the release source, the dependence of the building-wake modifications is illustrated by the divergence of the area-dependent curves.

The solutions to this equation are at best only estimates of the actual diffusion factor, not exact solutions. Since it is unlikely that a person would intentionally stand in a smokey plume near the source, a 


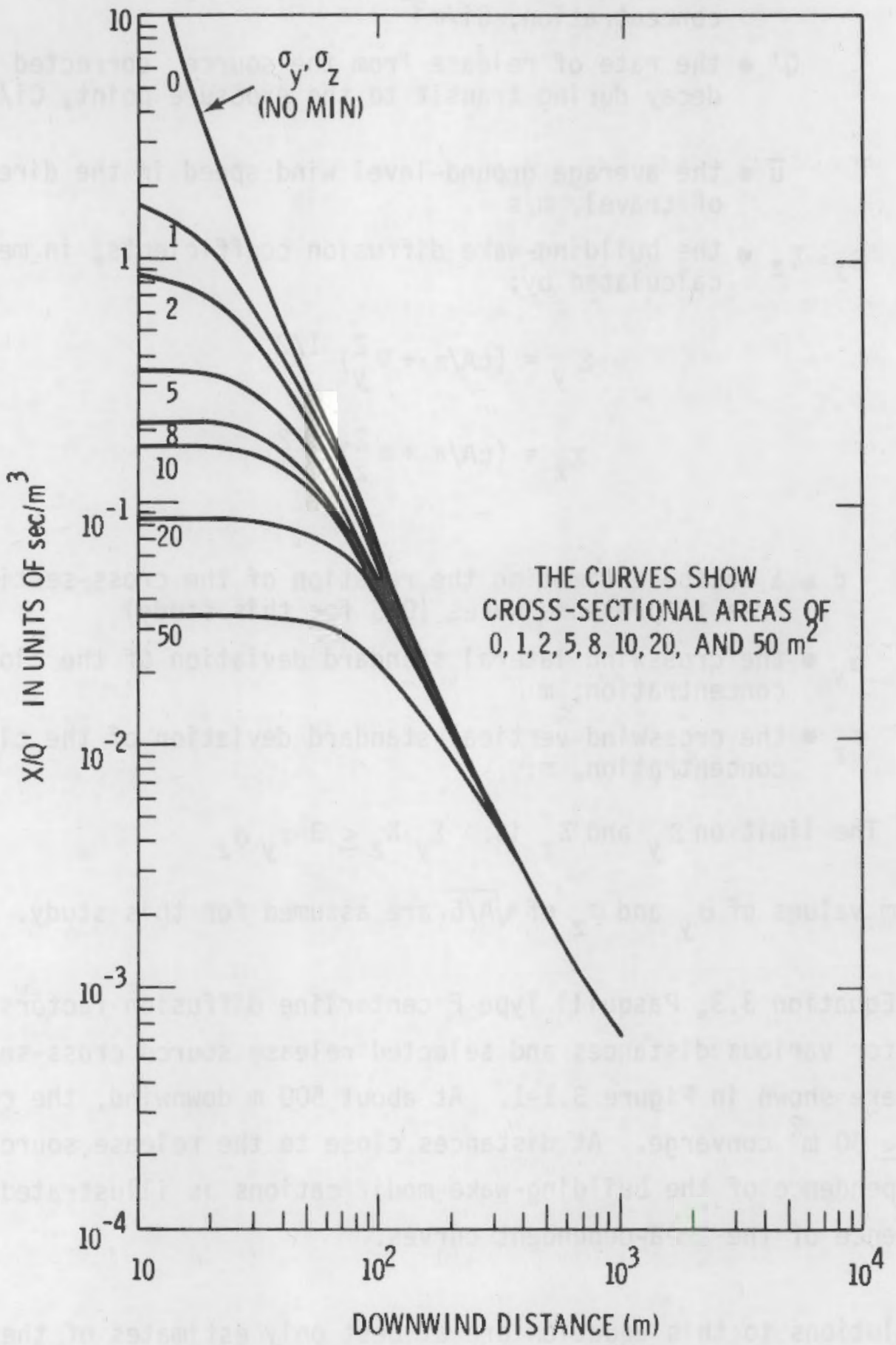

FIGURE 3.1-1 Pasquill Type $F$ Centerline $X / Q^{\prime}$ Values for BuildingWake Modification Factors Versus Downwind Distance 
distance of $100 \mathrm{~m}$ downwind is selected as the location of the maximumexposed individual. A value of $10^{-1} \mathrm{sec} / \mathrm{m}^{3}$ is selected at this location from Figure $3.1-1$ as being representative of the $X / Q^{\prime}$ values for various source cross-sectional areas.

Thus, inhalation doses for the incineration exposure scenarios of this study are based on the following assumptions:

- Air concentrations at distances greater than $200 \mathrm{~m}$ downwind (used for population dose scenarios) are found using the atmospheric diffusion factors given in Regulatory Guide 1.3 (USAEC 1974). The plume is assumed to travel uniformly within one downwind sector (22.5 degrees), and diffusion factors are found for ten distances out to $80 \mathrm{~km}$. The population density is assumed to be a constant 150 persons per square kilometer (0ak et al. 1980), with a total population of $1.9 \times 10^{5}$.

- The maximum-exposed individual is located at a distance of $100 \mathrm{~m}$ downwind with diffusion factor of $10^{-1} \mathrm{sec} / \mathrm{m}^{3}$.

- The release fraction from the fire is assumed to be similar to that measured from burning radioactive waste, $1.5 \times 10^{-4}$ (Mishima and Schwendiman 1973).

- Both the inside and outside of the transportation containers are assumed to have the same contamination level.

\subsubsection{Inhalation Directly from Hands}

In addition to inhalation from resuspension or incineration, inhalation of surface contamination transferred to the hands could occur. Breathing while rubbing the nose, changing clothes, or smoking cigarettes while surface contamination is present on the hands could produce a significant local airborne concentration in the vicinity of the nose and mouth. Available data comes from studies of airborne radioactive contamination while wearing or changing contaminated clothing. Healy (1971, pp. 21-23) gave a summary of previous studies and calculated decision levels based on the MPC in air for workers. The assumptions 
that Healy used were based on inhaling $10^{-4} \mathrm{~m}^{2}$ of surface contamination per day for all types of activities, including changing from contaminated clothing. Healy also stated that only continuous exposure was considered, and that no derivation for a single exposure was attempted since counter measures to such exposures are available. Dunster (1962, p. 4) indicated that the results of Bailey and Rohr (1953) showed that less than $0.1 \%$ of the contamination on the hands would be inhaled from a cigarette. Dunster further concluded that inhalation of radioactivity transferred from the skin would result in doses that are negligible by comparison to the dose received at the assumed rate of ingestion.

Again, like the ingestion and resuspension analyses for this study, modifications to the assumptions made in previous studies are required to calculate the dose-per-container received by workers and the public. Direct inhalation doses for the exposure scenarios of this study are calculated using the following assumptions:

- For workers, the equivalent of $5 \times 10^{-5} \mathrm{~m}^{2}$ of surface contamination is directly inhaled per container per worker. Th is value compares to a 30 minute ingestion exposure in the Healy (1971, p. 22) study.

- For containers released to the public after the contents have been removed, $1.0 \times 10^{-3} \mathrm{~m}^{2}$ of total container surface contamination is assumed to be inhaled by the maximum-exposed individual in the public. The inhalation by the maximum-exposed individual in the public assumes an individual who is near the container 20 times longer than a worker, and this compares to 10 hours of ingestion exposure in the Healy (1971) study.

\subsubsection{Direct Exposure}

Direct exposure from surface contamination can occur when an individual is in the vicinity of or in contact with containers used to transport radioactive materials. Three direct exposure cases for these containers are considered: 1) exposure to individuals from surface contamination (container contents not included), 2) exposure to individuals who 
acquire skin contamination from container surfaces, and 3) exposure to workers from the container contents during surface decontamination operations.

Radiation exposures are calculated by multiplying calculated dose rates by the exposure times for each container category. The dose rates are calculated using the ISOSHLD computer program (Engel et a T. 1966). The ISOSHLD program uses point kernel integrations and programed analytical solutions to calculate dose rates for various geometries. The following sections contain discussions of the three direct exposure pathways considered in this study.

\subsubsection{Surface Contamination}

The exposure to workers or individuals from surface contamination is calculated by multiplying the exposure rate for each scenario by the total time of exposure. The following assumptions are made to help define direct exposure from surface contamination:

- Each worker spends 30 minutes at an average distance of $1 \mathrm{~m}$ from each container.

- For containers released to the public, individuals spend 10 hours at an average distance of $1 \mathrm{~m}$ from each container.

\subsubsection{Skin Contamination}

Radioactive contamination may be transferred from the surface of containers to skin during handling. The skin area that will most probably be contaminated is the surface of the hands. The ICRP has set a maximum permissible dose of $75 \mathrm{rem} /$ year to the hands (ICRP 1966). Previous studies have defined permissible skin contamination by calculating the level of contamination that would deliver this dose rate to the basal layer of the skin (Gibson and Wrixon 1978; Dunster 1962). However, it is unrealistic to assume that skin contamination may be present continuously at the maximum permissible level. It is quite difficult to model the behavior of skin contamination on a per-container bas is since the 
skin area contaminated, contamination level, and duration of exposure are all subject to uncertainity. It is also difficult to relate skin contamination on the hands to total body dose since only isolated small areas of the body are involved. Thus, because of previous work and the uncertainties involved, no attempt is made in this study to calculate the dose to the hands from skin contamination. As shown in previous studies, the total body dose resulting from skin contamination is assumed to be negligible compared to the total body doses from ingestion and inhalation.

\subsubsection{Decontamination}

Additional decontamination to lower the levels of surface contamination is considered for some of the categories of containers defined in this study. For these containers, the additional occupational exposure received during decontamination should be weighed against the savings in occupational and public exposure resulting from lower surface contamination levels. The following assumptions are made to help define the occupational exposure received during decontamination:

- The direct exposure rates are controlled by the contents of the containers and are assumed not to exceed current DOT limits.

- Each worker is located at an average distance of $1 \mathrm{~m}$ from the container being decontaminated.

- The exposure rates and duration of operations are based on observations of industrial procedures as defined in the radiation exposure scenarios of this study.

\subsection{Radiopharmaceuticals}

Because of the many diagnostic and therapeutic uses of radiopharmaceuticals, it is impossible to select the radiopharmaceutical of most concern without first reviewing the most common ones in use today. Table 3.2-1 contains a listing of twenty common radiopharmaceuticals and their physical half-lives. Also included in this table are the maximum permissible concentrations in air, (MPC) $a$, for a continuous (168-hour per week) 
TABLE 3.2-1. Common Radiopharmaceuticals

\begin{tabular}{|c|c|c|}
\hline Radiopharmaceutical & $\begin{array}{l}\text { Physical } \\
\text { Half-Life } \\
\text { (Days) }\end{array}$ & $\begin{array}{c}(M P C)_{a}(a) \\
(\mathrm{Ci} / \mathrm{m})\end{array}$ \\
\hline${ }^{14} \mathrm{C}$ & $2.1 \times 10^{6}$ & $1 \times 10^{-7}$ \\
\hline $18_{F}$ & $7.6 \times 10^{-2}$ & $9 \times 10^{-8}$ \\
\hline${ }^{45} \mathrm{Ca}$ & $1.6 \times 10^{1}$ & $1 \times 10^{-9}$ \\
\hline${ }^{51} \mathrm{Cr}$ & $2.8 \times 10^{0}$ & $8 \times 10^{-8}$ \\
\hline${ }^{59} \mathrm{Fe}$ & $4.5 \times 10^{1}$ & $2 \times 10^{-9}$ \\
\hline${ }^{57} \mathrm{Co}$ & $2.7 \times 10^{2}$ & $6 \times 10^{-9}$ \\
\hline${ }^{64} \mathrm{Cu}$ & $5.4 \times 10^{-1}$ & $4 \times 10^{-8}$ \\
\hline${ }^{74} \mathrm{Se}$ & $1.8 \times 10^{1}$ & $4 \times 10^{-9}$ \\
\hline${ }^{75} \mathrm{Se}$ & $1.2 \times 10^{2}$ & $4 \times 10^{-9}$ \\
\hline${ }^{99 m} \mathrm{Tc}$ & $2.5 \times 10^{-1}$ & $5 \times 10^{-7}$ \\
\hline $113 \mathrm{~m}_{\mathrm{In}}$ & $7.1 \times 10^{-2}$ & $2 \times 10^{-7}$ \\
\hline $125_{I}$ & $6.0 \times 10^{1}$ & $8 \times 10^{-11}$ \\
\hline $131_{I}$ & $8.1 \times 10^{0}$ & $1 \times 10^{-10}$ \\
\hline $133 \mathrm{Xe}$ & $5.3 \times 10^{0}$ & $3 \times 10^{-7}$ \\
\hline${ }^{197} \mathrm{Hg}$ & $2.7 \times 10^{0}$ & $4 \times 10^{-8}$ \\
\hline${ }^{198}{ }_{\mathrm{Au}}$ & $2.7 \times 10^{0}$ & $8 \times 10^{-9}$ \\
\hline${ }^{201}$ & $3.0 \times 10^{0}$ & $3 \times 10^{-8}$ \\
\hline${ }^{203} \mathrm{Hg}$ & $4.6 \times 10^{1}$ & $2 \times 10^{-9}$ \\
\hline${ }^{203} \mathrm{pb}$ & $2.2 \times 10^{0}$ & $6 \times 10^{-8}$ \\
\hline${ }^{206} \mathrm{Bi}$ & $6.2 \times 10^{0}$ & $5 \times 10^{-9}$ \\
\hline
\end{tabular}

(a) The (MPC) a values are from Table II, Column 1 of 10 CFR 20, 1980, and are for the smallest value of either Soluble (S) or Insoluble (I) forms.

exposure (10 CFR 20). It should be remembered that the optimum radionuclide for a specific in vivo medical use is determined by considering both the types of radiation emitted and the chemical form used. Also, it is difficult to determine the relationship between the chemical form 
and the properties of the contamination on the surfaces of transportation containers. Therefore, the decision of which radiopharmaceutical to use in the radiation dose analysis is made based on the radiotoxicity as indicated by the (MPC) a from 10 CFR 20 . From the data listed in Table 3.3-1, ${ }^{125}$ I has the most restrictive (smallest) value of (MPC) $a$, and ${ }^{99 \mathrm{~m}} \mathrm{Tc}$ has the least restrictive (largest) value. As a comparison, radiation doses are calculated for both of these radiopharmaceuticals.

Radiation doses from surface contamination on containers used to transport radiopharmaceuticals are calculated and presented in the following sections. First, a reference radiopharmaceutical container design is defined. The reference container design is then used to help define the radiation exposure scenarios used in the dose calculations. Finally, the calculated doses are presented on a per-container bas is for a contamination level equal to current DOT limits.

\subsubsection{Reference Radiopharmaceutical Container}

A wide variety of containers are used to ship radiopharmaceuticals from the manufacturer to hospitals or research laboratories. Most of these containers are made of cardboard and their size varies among manufacturers for different radiopharmaceuticals. For this study, a reference container, similar to containers used to ship ${ }^{99 m} \mathrm{Tc}$ generators, is defined and used in the radiation dose scenarios. This container is defined to be cubic with side dimensions of $0.61 \mathrm{~m}$. The total surface area on the outside of the container is $2.2 \mathrm{~m}^{2}$. The reference container is selected as being representative of the containers used today, and no further attempt is made to model the specific differences found in container design.

\subsubsection{Radiopharmaceutical Radiation Exposure Scenarios}

Radiation exposure scenarios for radiopharmaceutical containers are defined in this section for each exposure pathway considered. These scenarios define the composite transportation worker, individual in the public, and population group for each radiopharmaceutical container. 
Total occupational doses are estimated by assuming that there are four individuals who are exposed equally at the same level as the composite individual transportation worker. For the public, three basic situations are considered: empty containers that are released to the public ( $5 \%$ of the tota 1), empty containers that are disposed of by the receiver by incineration (55\% of the total), and empty containers that are disposed of as low-level radioactive waste (40\% of the total). The following sections contain the radiopharmaceutical exposure scenarios for direct ingestion, inhalation, and direct exposure.

\subsubsection{Direct Ingestion}

Specific assumptions for direct ingestion are discussed in Section 3.1.1. Workers are assumed to ingest $5 \times 10^{-5} \mathrm{~m}^{2}$ of surface contamination from the container. An individual in the public is assumed to use an empty container at home and ingest the contamination from $1.0 \times 10^{-3} \mathrm{~m}^{2}$ of surface as defined in Section 3.1.1. Again, only $5 \%$ of the packages are assumed to be released to the public, and $55 \%$ are inc inerated with $40 \%$ disposed of as low-level radioactive waste. This amount of ingestion is assumed to account for all pathways from the container surface to the mouth including transfer from hands, foodstuffs, cigarettes, and truck surfaces with secondary transfer to items entering the mouth. The composite individual in the public is also assumed to be a member of the composite population group.

\subsubsection{Inhalation}

Specific assumptions for inhalation are discussed in Section 3.1.2. For resuspended material from the container surface, the local air concentrations (in $\mathrm{C} i$ per $\mathrm{m}^{3}$ ) are found using Equation 3.1. Where $\Omega$ equals the surface contamination level (in $\mathrm{C} i / \mathrm{m}^{2}$ ), the resulting air concentrations are calculated to be: $\left[1.4 \times 10^{-6} \cdot \Omega\right]$ in the shipping or receiving room, $\left[1.9 \times 10^{-6} \cdot \Omega\right]$ in the closed transport vehicle, and $\left[9.2 \times 10^{-6} \cdot \Omega\right]$ in a room at a private family dwelling. Again, it is assumed that only $5 \%$ of all containers are released to the public after their use. For incineration, it is assumed that it takes 3 minutes to 
burn the cardboard shipping container, and that the plume travels in a straight-line direction downwind at ground level in one sector (22.5 degrees). Atmospheric dispersion factors are found for the population at each of 10 downwind distances out to $80 \mathrm{~km}$ from Figures $3 \mathrm{~A}$ and $3 \mathrm{~B}$ in Reg. Guide 1.3. It is assumed that a constant population density of 150 people per $\mathrm{km}^{2}$ are exposed in the downwind sector, for a total population of $1.9 \times 10^{5}$. With these assumptions, integrated air concentrations are calculated. The resulting air concentrations (in people $\mathrm{Ci} / \mathrm{m}^{3}$ ) for incineration are: $\left[3.7 \times 10^{-7} \cdot \Omega\right]$ and $\left[1.5 \times 10^{-6} \cdot \Omega\right]$ for the individual (located $100 \mathrm{~m}$ downwind) in the public and the population group. Again, $\Omega$ is the surface contamination level (in $\mathrm{Ci} / \mathrm{m}^{2}$ ). No workers are assumed to be exposed during incineration, and only $55 \%$ of all containers are assumed to be incinerated. For direct inhalation from container surfaces, the assumptions are listed in Section 3.1.2.3. Workers are assumed to inhale the equivalent of $5.0 \times 10^{-5} \mathrm{~m}^{2}$ of surface contamination, and an individual in the public is assumed to inhale the equivalent of $1.0 \times 10^{-3} \mathrm{~m}^{2}$ of surface contamination. Only $5 \%$ of all containers are assumed to be released to the public. The individual who takes home the container is included as part of the composite population group.

\subsubsection{Direct Exposure}

The details of the direct exposure calculations are discussed in Section 3.1.3. Each transportation worker spends 30 minutes at an average distance of $1 \mathrm{~m}$ from the container, and the individuat in the public spends 10 hours at an average distance of $1 \mathrm{~m}$. No decontamination exposure is considered for this case.

\subsubsection{Radiation Doses from Radiopharmaceutical Transportation Containers}

The results of radiation dose calculations performed for the surface contamination exposure scenarios for radiopharmaceutical containers are presented in Tables 3.2-2 through 3.2-4. These doses are calculated 
TABLE 3.2-2. Individual and Collective Doses to Composite Workers from Surface Contamination - Radiopharmaceutical Transportation Containers (at $10^{-4} \mu \mathrm{Ci} / \mathrm{cm}^{2}$ )

\begin{tabular}{|c|c|c|c|c|c|c|c|c|}
\hline \multirow{2}{*}{ Radionuclide/Pathway } & \multicolumn{4}{|c|}{ First-Year Dose Equivalent (rem) } & \multicolumn{4}{|c|}{50 , Year Committed Dose Equivalent (rem) } \\
\hline & $\begin{array}{l}\text { Weighted } \\
\text { Total Body }\end{array}$ & Bone & Lung & Thyroid & $\begin{array}{l}\text { Weighted } \\
\text { Total Body }\end{array}$ & gone & Lung & Thyroid \\
\hline \multicolumn{9}{|l|}{$125_{I}$} \\
\hline $\begin{array}{l}\text { Inha lat ion } \\
\text { Loading; Un loading }\end{array}$ & $1.7 \times 10^{-8}$ & $--(b)$ & $2.1 \times 10^{-10}$ & $5.8 \times 10^{-7}$ & $1.7 \times 10^{-8}$ & $---(b)$ & $2.1 \times 10^{-10}$ & $5.8 \times 10^{-7}$ \\
\hline Closed Vehicle & $2.4 \times 10^{-8}$ & --- & $2.9 \times 10^{-10}$ & $7.9 \times 10^{-7}$ & $2.4 \times 10^{-8}$ & $\cdots$ & $2.9 \times 10-10$ & $7.9 \times 10^{-7}$ \\
\hline Direct From Hands & $3.6 \times 10^{-10}$ & --- & $4.2 \times 10^{-12}$ & $1.2 \times 10^{-8}$ & $3.6 \times 10^{-10}$ & $\cdots$ & $4.2 \times 10^{-12}$ & $1.2 \times 10^{-8}$ \\
\hline Ingestion & $2.4 \times 10^{-6}$ & $\cdots$ & $\cdots$ & $8.0 \times 10^{-5}$ & $2.4 \times 10^{-6}$ & -- & --- & $8.0 \times 10^{-5}$ \\
\hline $\begin{array}{l}\text { Total Composite } \\
\text { Worker }\end{array}$ & $2.4 \times 10^{-6}$ & --- & $5.0 \times 10^{-10}$ & $8.1 \times 10^{-5}$ & $2.4 \times 10^{-6}$ & --- & $5.0 \times 10^{-10}$ & $8.1 \times 10^{-5}$ \\
\hline $\begin{array}{l}\text { Total Occupational(c) } \\
\text { (man-rem) }\end{array}$ & $9.8 \times 10^{-6}$ & --- & $2.0 \times 10^{-9}$ & $3.3 \times 10^{-4}$ & $9.8 \times 10^{-6}$ & --- & $2.0 \times 10^{-9}$ & $3.3 \times 10^{-4}$ \\
\hline \multicolumn{9}{|l|}{$99 m_{T C}$} \\
\hline $\begin{array}{l}\text { Inhalation } \\
\text { Lodding/Unloading }\end{array}$ & $3.0 \times 10^{-10}$ & $8.0 \times 10^{-14}$ & $2.5 \times 10^{-9}$ & -- & $3.0 \times 10^{-10}$ & $8.0 \times 10^{-14}$ & $2.5 \times 10^{-9}$ & $\cdots$ \\
\hline Closed Vehicle & $4.1 \times 10^{-10}$ & $1.1 \times 10^{-13}$ & $3.4 \times 10^{-9}$ & -- & $4.1 \times 10^{-10}$ & $1.1 \times 10^{-13}$ & $3.4 \times 10^{-9}$ & $\cdots$ \\
\hline Direct From Hands & $6.0 \times 10^{-12}$ & $1.6 \times 10^{-15}$ & $5.0 \times 10^{-11}$ & $\cdots$ & $6.0 \times 10^{-12}$ & $1.6 \times 10^{-15}$ & $5.0 \times 10^{-11}$ & -- \\
\hline Ingestion & $1.4 \times 10^{-12}$ & $1.2 \times 10^{-11}$ & --- & -- & $1.4 \times 10^{-12}$ & $1.2 \times 10^{-11}$ & $\cdots$ & -- \\
\hline $\begin{array}{l}\text { Total Composite } \\
\text { Worker }\end{array}$ & $7.2 \times 10^{-10}$ & $1.2 \times 10^{-11}$ & $6.0 \times 10^{-9}$ & $\cdots$ & $7.2 \times 10^{-10}$ & $1.2 \times 10^{-11}$ & $6.0 \times 10^{-9}$ & -- \\
\hline $\begin{array}{l}\text { Total Occupational }(c) \\
\text { (man-rem) }\end{array}$ & $2.9 \times 10^{-9}$ & $4.9 \times 10^{-10}$ & $2.4 \times 10^{-8}$ & -- & $2.9 \times 10^{-9}$ & $4.9 \times 10^{-11}$ & $2.4 \times 10^{-8}$ & $\cdots$ \\
\hline
\end{tabular}


TABLE 3.2-3. Doses to the Composite Individual in the Public from Surface Contamination - Radiopharmaceutical Transportation Containers (at $10^{-4} \mu \mathrm{Ci} / \mathrm{cm}^{2}$ )

\begin{tabular}{|c|c|c|c|c|c|c|c|c|}
\hline \multirow[b]{2}{*}{ Radionuclide/Pathway } & \multicolumn{4}{|c|}{ Eirst-Year Dose Equivalent (rem) } & \multicolumn{4}{|c|}{50, Year Committed Dose Equivalent (rem) } \\
\hline & $\begin{array}{l}\text { Weighted } \\
\text { Total Body }\end{array}$ & Bone & Lung & Thyroid & $\begin{array}{l}\text { Weighted } \\
\text { Total Body }\end{array}$ & Bone & Lung. & Thyroid \\
\hline \multicolumn{9}{|l|}{$125_{I}$} \\
\hline $\begin{array}{l}\text { Intalation } \\
\text { Private Family } \\
\text { Dwelling }\end{array}$ & $1.2 \times 10^{-7}$ & $\ldots(b)$ & $1.4 \times 10^{-9}$ & $3.9 \times 10^{-6}$ & $1.2 \times 10^{-7}$ & $\ldots(b)$ & $1.4 \times 10^{-9}$ & $3.9 \times 10^{-6}$ \\
\hline Incineration & $2.4 \times 10^{-10}$ &.-- & $2.8 \times 10^{-12}$ & $8.0 \times 10^{-9}$ & $2.4 \times 10-10$ & --- & $2.8 \times 10^{-12}$ & $8.0 \times 10^{-9}$ \\
\hline Direct From Hands & $3.6 \times 10^{-10}$ & --- & $4.2 \times 10^{-12}$ & $1.2 \times 10^{-8}$ & $3.6 \times 10^{-10}$ & $\cdots$ & $4.2 \times 10^{-12}$ & $1.2 \times 10^{-8}$ \\
\hline Ingest ion & $2.7 \times 10^{-6}$ & $\cdots$ & $\cdots$ & $9.0 \times 10^{-5}$ & $2.7 \times 10^{-6}$ & $-\cdot-$ & --- & $9.0 \times 10^{-5}$ \\
\hline $\begin{array}{l}\text { Total Composite } \\
\text { Individuat }\end{array}$ & $2.8 \times 10^{-6}$ & --- & $1.4 \times 10^{-9}$ & $9.4 \times 10^{-5}$ & $2.8 \times 10^{-6}$ & --- & $1.4 \times 10^{-9}$ & $9.4 \times 10^{-5}$ \\
\hline \multicolumn{9}{|l|}{$99 \mathrm{mTC}$} \\
\hline $\begin{array}{l}\text { Inhalation } \\
\text { Private Family } \\
\text { Owelling. }\end{array}$ & $1.8 \times 10^{-9}$ & $5.5 \times 10^{-13}$ & $1.5 \times 10^{-8}$ &.- & $1.8 \times 10^{-9}$ & $5.5 \times 10^{-13}$ & $1.5 \times 10^{-8}$ & +- \\
\hline Incineration & $8.0 \times 10^{-12}$ & $2.1 \times 10^{-15}$ & $6.7 \times 10-11$ & -- & $8.0 \times 10^{-12}$ & $2.1 \times 10^{-15}$ & $6.7 \times 10^{-11}$ &.- \\
\hline Direct From Hands & $6.0 \times 10^{-12}$ & $1.6 \times 10-15$ & $5.0 \times 10^{-11}$ & --- & $6.0 \times 10^{-12}$ & $1.6 \times 10-15$ & $5.0 \times 10-11$ & -- \\
\hline Ingestion & $7.2 \times 10^{-12}$ & $6.0 \times 10^{-11}$ & -- & -- & $7.2 \times 10^{-12}$ & $6.0 \times 10^{-11}$ & $\cdots$ & $\cdots$ \\
\hline $\begin{array}{l}\text { Total Compossite } \\
\text { Individual }\end{array}$ & $1.8 \times 10^{-9}$ & $6.1 \times 10^{-11}$ & $1.5 \times 10^{-8}$ & -- & $1.8 \times 10^{-9}$ & $6.1 \times 10^{-11}$ & $1.5 \times 10^{-8}$ & --- \\
\hline
\end{tabular}


TABLE 3.2-4. Collective Dose to the Composite Population Group from Surface Contamination - Radiopharmaceutical Transportation Containers $(a)$ (at $10^{-4} \mathrm{\mu Ci} / \mathrm{cm}^{2}$ )

\section{First-Year Dose Equivalent (man-rem)}

Radionuc lide/Pathway Iotal Body $125 \mathrm{I}$

Inhalation
Private Family
Dwelling

Inc ineration

$1.2 \times 10^{-7}$

$1.0 \times 10^{-9}$

Direct From Hands

Ingest ion

Total Composite

Population

99m Tc

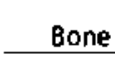
Lung

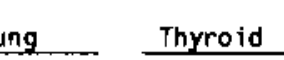

Thyroid $\frac{50+}{\text { Weighted }}$ 50 Ye Iotal Body. y Committed Dase Bone Lung Thyroid 
based on current DOT surface contamination limits for beta-gamma emitters $\left(1 \times 10^{-4} \mu \mathrm{Ci} / \mathrm{cm}^{2}\right)$. Table 3.2-2 contains the calculated doses to a composite worker. An estimate of the collective occupational dose from surface contamination is a]so listed in this table based on the assumption that the total occupational dose is four times larger than the dose calculated for the composite worker. This assumption appears to be cons istant with current industry estimates of labor requirements.

Radiation doses to members of the public are presented in Tables 3.2-3 and $3.2-4$. The radiation dose to a composite individual in the public is listed in Table 3.2-3, and the collective dose to the population group is listed in Table 3.2-4. The composite individual and population doses are controlled by the dose from the $5 \%$ of all empty containers that are released to the public. Incineration of $55 \%$ of the containers results in only a small increment of additional dose.

All of the doses reported in these tables are for the inhalation and ingestion dose pathways. A preliminary calculation indicated that the dose from direct exposure is about three orders of magnitude less than the dose from ingestion. Thus, the doses from direct exposure to radiopharmaceutical surface contamination are omitted from these tables.

The dose calculations are performed for both ${ }^{125}$ I and ${ }^{99 m}$ Tc to demonstrate the radionuclide dependence of the dose calculations. Specifically, the dose to thyroid from ${ }^{125} \mathrm{I}$ is about four orders of magnitude larger than the dose from ${ }^{99 m} \mathrm{Tc}$ to lung. The wighted total body doses for ${ }^{125}$ I are about three orders of magnitude larger than those from $99 \mathrm{~m} T \mathrm{~T}$.

\subsection{Industrial Sources}

A wide variety of radionuclides are used in industry for specific applications. These applications include use in gauges, static eliminators, and industrial radiographic devices. Table 3.3-1 contains a summary of the more common radionuclides used by industry and their physical halflives. Also included in this table are the MPC values in air from Table 
II, Column 1, of 10 CFR 20. Since most of the radionuclides used in industry are shipped as encapsulated sources, there appears to be a low potential for surface contamination unless the capsule is broken. From the data listed in Table 3.3-1, the following radionuclides are selected on the basis of their (MPC) for use in the dose calculations: ${ }^{241}$ An for alpha, ${ }^{90} \mathrm{Sr}$ for beta, and ${ }^{60}$ Co for garma-ray emitters. As a comparison, the dose calculations are also made for ${ }^{63} \mathrm{Ni}$, a less-toxic beta emitter.

TABLE 3.3-1. Common Industrial Source Radionuclides

\begin{tabular}{|c|c|c|c|c|c|}
\hline Radionuc lide & $\begin{array}{l}\text { Physical } \\
\text { Half-Life } \\
\text { (Years) }\end{array}$ & $\begin{array}{l}(\mathrm{MPC})_{\mathrm{a}}{ }^{(a)} \\
\left(\mu \mathrm{Ci} / \mathrm{m}^{\mathrm{m}}\right)\end{array}$ & Radionuclide & $\begin{array}{l}\text { Physical } \\
\text { Half-Life } \\
\text { (Years) }\end{array}$ & $\begin{array}{l}(M P C)^{(a)} \\
(\mu C i / m)\end{array}$ \\
\hline $3_{H}$ & $12 \times 10^{1}$ & $2 \times 10^{-7}$ & ${ }^{13} \mathrm{cs}$ & $3.0 \times 10^{1}$ & $5 \times 10^{-10}$ \\
\hline${ }^{22} \mathrm{Na}$ & $2.6 \times 10^{0}$ & $3 \times 10^{-10}$ & ${ }^{147} \mathrm{Pm}$ & $2.6 \times 10^{0}$ & $2 \times 10^{-9}$ \\
\hline${ }^{59} \mathrm{Fe}$ & $1.2 \times 10^{-1}$ & $2 \times 10^{-10}$ & ${ }^{192} \mathrm{Ir}$ & $2.0 \times 10^{-1}$ & $9 \times 10^{-10}$ \\
\hline${ }^{60} \mathrm{Co}$ & $5.3 \times 10^{0}$ & $3 \times 10^{-10}$ & ${ }^{210}$ Po & $3.8 \times 10^{-1}$ & $7 \times 10^{-12}$ \\
\hline${ }^{63} \mathrm{Ni}$ & $9.2 \times 10^{1}$ & $2 \times 10^{-9}$ & $210 \mathrm{pb}$ & $2.1 \times 10^{1}$ & $4 \times 10^{-12}$ \\
\hline${ }^{85} \mathrm{Kr}$ & $1.1 \times 10^{1}$ & $3 \times 10^{-7}$ & ${ }^{226} \mathrm{Ra}$ & $1.6 \times 10^{3}$ & $2 \times 10^{-12}$ \\
\hline${ }^{90} \mathrm{Sr}$ & $2.8 \times 10^{1}$ & $3 \times 10^{-11}$ & & $1.9 \times 10^{0}$ & $2 \times 10^{-13}$ \\
\hline${ }^{109} \mathrm{Cd}$ & $1.2 \times 10^{0}$ & $2 \times 10^{-9}$ & 241 & $4.3 \times 10^{2}$ & $2 \times 10^{-13}$ \\
\hline${ }^{134} \mathrm{Cs}$ & $2.1 \times 10^{0}$ & $4 \times 10^{-10}$ & & $1.8 \times 10^{1}$ & $3 \times 10^{-13}$ \\
\hline
\end{tabular}

(a) The (MPC) a values are from Table II, Column 1 of 10 CFR 20, 1980, and are for the smallest value of either soluble (S) or Insoluble (I) forms.

Radiation doses from surface contamination on containers used to transport industrial source materials are calculated and presented in the following sections. First, a reference transportation container design for industrial sources is defined. This container is used in radiation exposure scenarios to define radiation exposures to workers and the public. Finally, the calculated radiation doses are presented on a per-container basis for a contamination level equal to current OOT limits. 


\subsubsection{Reference Industrial Source Container}

A wide variety of containers are used to ship industrial source materials from manufacturers to users. A large fraction of the containers are made from cardboard and are similar to the containers used to ship radiopharmaceuticals. For this study, the reference container design is defined to be a cubic cardboard box with side dimensions of $0.61 \mathrm{~m}$, the same box defined for radiopharmaceuticals. The total surface area on the outside of the container is $2.2 \mathrm{~m}^{2}$. The reference container is selected as being representative of the majority of the containers used today, and no further attempt is made to model the specific differences found in container design.

\subsubsection{Industrial Source Radiation Exposure Scenarios}

Since the same reference container is defined for both radiopharmaceuticals and industrial sources, the radiation exposure scenarios are also the same. The only difference is the radionuclides considered on the container surfaces. The empty containers are also assumed to be disposed of in the same manner: $5 \%$ are released to the public, $55 \%$ are incinerated, and $40 \%$ are disposed of as low-level radioactive waste. Specific details for the exposure pathways are found in Section 3.2.2.1 for ingestion, Section 3.2.2.2 for inhalation, and Section 3.2.2.3 for direct exposure. No decontamination exposure is considered for this container category.

\subsubsection{Radiation Doses from Industrial Source Transportation Containers} The results of radiation dose calculations performed for the surface contamination exposure scenarios for industrial source material containers are presented in Tables 3.3-2 through 3.3-4. These doses are calculated based on current DOT surface contamination limits (i.e., $1 \times 10^{-5} \mu \mathrm{Ci} / \mathrm{cm}^{2}$ for alpha and $1.0 \times 10^{-4} \mu \mathrm{Ci} / \mathrm{cm}^{2}$ for beta-ganma emitters). Table 3.3-2 contains the calculated doses to a composite worker and an estimate of the total occupational dose. This total is found by assuming that it is four times larger than the dose to the composite 


\section{TABLE 3.3-2. Individual and Collective Doses to Composite Workers from Surface Contamination - Industrial Source Material Transportation Containers (at $10^{-5} \mu \mathrm{Ci} / \mathrm{cm}^{2}$ for $\alpha$ and $10^{-4} \mu \mathrm{C} i / \mathrm{cm}^{2}$ for $\beta-\gamma$ )}

\begin{tabular}{|c|c|c|c|c|c|c|c|c|}
\hline \multirow[b]{2}{*}{ Radianuc lide/Pathway } & \multicolumn{4}{|c|}{ fo first-Year Dose Equivalent (rem). } & \multicolumn{4}{|c|}{ 50, fear CMmitted Dose Equivalent (rem) } \\
\hline & $\begin{array}{l}\text { Weighted i } \\
\text { Iotal gody. }\end{array}$ & - Bone & Lung & Thyroid & $\begin{array}{l}\text { Wetightedt } \\
\text { Intal Body }\end{array}$ & Bone - & Lung ... & Thyroid \\
\hline \multicolumn{9}{|l|}{$241_{\mathrm{Am}}$} \\
\hline $\begin{array}{l}\text { Inhal at ion } \\
\text { Loading/Un losd ing }\end{array}$ & $2.5 \times 10^{-6}$ & $3.1 \times 20^{-6}$ & $1.8 \times 10^{-5}$ & $---(b)$ & $2.2 \times 10^{-5}$ & $1.4 \times 10^{-4}$ & $4.5 \times 10^{-5}$ & $\ldots\{b\}$ \\
\hline Closed vehicle & $3.5 \times 10^{-6}$ & $4.2 \times 10^{-6}$ & $2.5 \times 10^{-5}$ & $\cdots$ & $3.0 \times 10^{-5}$ & $1.9 \times 10^{-4}$ & $6.2 \times 10^{-5}$ & $\cdots$ \\
\hline Direct From Hands & $5.0 \times 10^{-8}$ & $6.1 \times 10^{-8}$ & $3.6 \times 10^{-7}$ & $\cdots$ & $4.4 \times 10^{-7}$ & $2.8 \times 10^{-6}$ & $9.0 \times 10^{-7}$ & $\cdots$ \\
\hline Ingestion & $2.0 \times 10^{-8}$ & $1.7 \times 10^{-7}$ & $\cdots$ & $\cdots$ & $2.4 \times 10^{-7}$ & $2.0 \times 10^{-6}$ & -- & --- \\
\hline $\begin{array}{l}\text { Total Composite } \\
\text { Worker }\end{array}$ & $6.1 \times 10^{-6}$ & $7.5 \times 10^{-6}$ & $4.3 \times 10^{-5}$ & --- & $5.3 \times 10^{-5}$ & $3.4 \times 10^{-4}$ & $1.1 \times 10^{-4}$ & $\cdots$ \\
\hline $\begin{array}{l}\text { Total Occupational(c) } \\
\text { (man-rem) }\end{array}$ & $2.9 \times 10^{-5}$ & $3.0 \times 10^{-5}$ & $1.7 \times 10^{-4}$ & $\cdots$ & $2.1 \times 10^{-4}$ & $1.9 \times 10^{-3}$ & $4.3 \times 10^{-4}$ & -- \\
\hline \multicolumn{9}{|l|}{$905 r-90 Y$} \\
\hline $\begin{array}{l}\text { Inhalation } \\
\text { Lodding/Un loading }\end{array}$ & $3.0 \times 10^{-7}$ & $5.1 \times 10^{-7}$ & $2.0 \times 10^{-6}$ & -- & $1.9 \times 10^{-6}$ & $1.1 \times 10^{-5}$ & $4.8 \times 10^{-6}$ & $\cdots$ \\
\hline Closed Yenicle & $4.0 \times 10^{-7}$ & $6.5 \times 10^{-7}$ & $2.7 \times 10^{-6}$ & -- & $2.6 \times 10^{-6}$ & $1.5 \times 10^{-5}$ & $6.5 \times 10^{-6}$ & --- \\
\hline Direct From Hands & $5.9 \times 10^{-9}$ & $9.5 \times 10^{-9}$ & $4.0 \times 10^{-8}$ & -- & $3.9 \times 10^{-8}$ & $2.2 \times 10^{-7}$ & $9.5 \times 10^{-8}$ & $\cdots$ \\
\hline Ingestion & $2.0 \times 10^{-5}$ & $1.7 \times 10^{-5}$ & $--\cdot$ & $\ldots$ & $2.3 \times 10^{-5}$ & $1.9 \times 10^{-4}$ & --- & --- \\
\hline $\begin{array}{l}\text { Total Composite } \\
\text { Worker }\end{array}$ & $2.7 \times 10^{-6}$ & $1.9 \times 10^{-5}$ & $4.7 \times 20^{-6}$ & $\cdots$ & $2.7 \times 10^{-5}$ & $7.2 \times 10^{-4}$ & $1.4 \times 10^{-5}$ & $\cdots$ \\
\hline $\begin{array}{l}\text { Total occupationalic\} } \\
\text { \{man-rem\} }\end{array}$ & $1.1 \times 10^{-5}$ & $7.3 \times 10-5$ & $1.9 \times 10^{-5}$ & $\cdots$ & $1.1 \times 10^{-4}$ & $9.6 \times 10^{-9}$ & $4.6 \times 10.5$ & --- \\
\hline \multicolumn{9}{|l|}{${ }^{60} \mathrm{CO}$} \\
\hline $\begin{array}{l}\text { Inhalation } \\
\text { Lodding/Unlodding }\end{array}$ & $1.4 \times 10^{-7}$ & $-\cdot-$ & $1.2 \times 10^{-6}$ & $\cdots$ & $3.1 \times 10^{-7}$ & $-\cdot$ & $2.6 \times 10^{-6}$ & $\cdots$ \\
\hline Closed Yehicle & $2.0 \times 10^{-7}$ & $\cdots$ & $\therefore .7 \times 10^{-6}$ & $\cdots$ & $4.2 \times 10^{-9}$ & $\cdots$ & $3.5 \times 10^{-6}$ & $\cdots$ \\
\hline Direct from Hands & $2.9 \times 10^{-9}$ & $-\cdot$ & $2.4 \times 10^{-5}$ & $\cdots$ & $6.7 \times 10^{-9}$ & $\cdots$ & $5.2 \times 10^{-8}$ & \\
\hline Ingestion & $5.3 \times 10^{.6}$ & -- & $\cdots$ & $\cdots$ & $1.1 \times 10^{-5}$ & $\cdots$ & $\cdots$ & -- \\
\hline $\begin{array}{l}\text { Total Composite } \\
\text { Horker }\end{array}$ & $5.7 \times 10^{-6}$ & $\cdots$ & $2.9 \times 10^{-6}$ & $\cdots$ & $1.1 \times 10^{-5}$ & $\cdots$ & $6.2 \times 10^{-6}$ & $\cdots$ \\
\hline $\begin{array}{l}\text { Total Occupational }{ }^{(c)} \\
\text { (man-ren!) }\end{array}$ & $2.3 \times 10^{-5}$ & $\cdots$ & $1.2 \times 10^{-5}$ & $\cdots$ & $4.5 \times 10^{-5}$ & $\cdots$ & $2.5 \times 10^{-5}$ & $\cdots$ \\
\hline \multicolumn{9}{|l|}{$63_{\mathrm{Ni}}$} \\
\hline $\begin{array}{l}\text { Inhelat ion } \\
\text { Load ing/Un looding }\end{array}$ & $4.4 \times 10^{-9}$ & $2.7 \times 10^{-8}$ & $9.5 \times 10^{-3}$ & $\cdots$ & $1.2 \times 30^{-8}$ & $1.0 \times 10^{-7}$ & $9.5 \times 10^{-9}$ & $\cdots$ \\
\hline Closed Vehicle & $6.0 \times 10^{-9}$ & $3.7 \times 10^{-8}$ & $1.3 \times 10^{-8}$ & $\cdots$ & $1.8 \times 10^{-8}$ & $1.4 \times 50^{-7}$ & $1.3 \times 10^{-8}$ & --- \\
\hline Direct From Hands & $2.9 \times 10^{-11}$ & $5.4 \times 10^{-10}$ & $1.9 \times 10^{-10}$ & $-\cdot$ & $7.6 \times 10^{-10}$ & $6.1 \times 10^{-9}$ & $1.9 \times 10^{-10}$ & $\cdots$ \\
\hline Ingest ion & $2.2 \times 10^{-7}$ & $1.8 \times 10^{-6}$ & $\cdots$ & $\cdots$ & $7.8 \times 10^{-7}$ & $6.5 \times 10^{-6}$ & --- & -- \\
\hline $\begin{array}{l}\text { Total Composite } \\
\text { Worker }\end{array}$ & $2.3 \times 10^{-7}$ & $1.8 \times 10^{-6}$ & $\cdots$ & $\ldots$ & $7.8 \times 10^{-7}$ & $6.5 \times 10^{-6}$ & $\cdots$ & -- \\
\hline $\begin{array}{l}\text { Total Occ.upational }(c) \\
\text { (man-rem) }\end{array}$ & $9.1 \times 10^{-7}$ & $7.5 \times 10^{-6}$ & $9.2 \times 10^{-B}$ & $\cdots$ & $3.2 \times 10.6$ & $2.7 \times 10^{-5}$ & $9.1 \times 10^{-8}$ & $\cdots$ \\
\hline
\end{tabular}


IABLE 3.3-3. Doses to the Composite Individual in the Public from Surface Contamination - Industrial Source Material Transportation Containers (at $10^{-5} \mu \mathrm{Ci} / \mathrm{cm}^{2}$ for $\alpha$ and $10^{-4} \mu \mathrm{Ci} / \mathrm{cm}^{2}$ for $\left.\beta-\gamma\right)$

\begin{tabular}{|c|c|c|c|c|c|c|c|c|}
\hline \multirow[b]{2}{*}{ Radionuclide/Pathway } & \multicolumn{4}{|c|}{ Efrst-Year Dose Equivalent (ren) } & \multicolumn{4}{|c|}{ 50 Year Comitted Dose Equivalent (rem) } \\
\hline & $\begin{array}{l}\text { We ighted } \\
\text { Total Body }\end{array}$ & Bone & Lung ___ & Thyroid & $\begin{array}{l}\text { Weighted } \\
\text { total Body }\end{array}$ & Bone & Lung & Thyro if \\
\hline \multicolumn{9}{|l|}{$241_{\text {Am }}$} \\
\hline $\begin{array}{l}\text { Inhalation } \\
\text { Private Family } \\
\text { Dwelling }\end{array}$ & $1.7 \times 10^{-5}$ & $2.1 \times 10.5$ & $1.2 \times 10^{-4}$ & $\ldots(b)$ & $1.5 \times 10^{-4}$ & $9.4 \times 10^{-4}$ & $3.1 \times 10^{-4}$ & $\ldots$ (b) \\
\hline Incineration & $3.8 \times 10^{-8}$ & $4.5 \times 10^{-8}$ & $2.7 \times 10^{-7}$ & $\cdots$ & $3.2 \times 10^{-7}$ & $2.0 \times 10^{-6}$ & $6.7 \times 10^{-7}$ & -- \\
\hline Direct From Hands & $5.1 \times 10-8$ & $6.1 \times 10^{-8}$ & $3.6 \times 10^{-7}$ & -- & $4.4 \times 10^{-7}$ & $2.8 \times 10^{-6}$ & $9.0 \times 10^{-7}$ & $\cdots$ \\
\hline ingest ion & $2,3 \times 10^{-8}$ & $1.9 \times 10^{-7}$ & $\cdots$ & $\cdots$ & $9.0 \times 10^{-7}$ & $7.5 \times 10^{-6}$ & $\cdots$ & $\cdots$ \\
\hline $\begin{array}{l}\text { Tatal Composite } \\
\text { Individual }\end{array}$ & $1.7 \times 10^{-5}$ & $2.1 \times 10^{-5}$ & $1.2 \times 10^{-4}$ & --- & $1.5 \times 10^{-4}$ & $9.5 \times 10^{-4}$ & $3.1 \times 10^{-4}$ & $\cdots$ \\
\hline \multicolumn{9}{|l|}{$9_{S r}-90_{Y}$} \\
\hline $\begin{array}{l}\text { Ingalation } \\
\text { Private Fanily } \\
\text { Drelling }\end{array}$ & $1.9 \times 10^{-6}$ & $3.2 \times 10^{-6}$ & $1.3 \times 10^{-5}$ & -- & $1.2 \times 10^{-5}$ & $7.0 \times 10^{-5}$ & $3.2 \times 10^{-5}$ & $\cdots$ \\
\hline Incineration & $3.9 \times 10^{-9}$ & $6.3 \times 10-9$ & $2.6 \times 10^{-8}$ & $\cdots$ & $2.4 \times 10^{-8}$ & $1.4 \times 10^{-7}$ & $6.3 \times 10^{-8}$ & 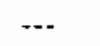 \\
\hline Direct from Hands & $5.9 \times 10^{-9}$ & $9.5 \times 10^{-9}$ & $4.0 \times 10-8$ & $-\cdots$ & $3.8 \times 10^{-8}$ & $2.2 \times 10^{-7}$ & $9.5 \times 10^{-8}$ & --- \\
\hline ingestion & $2.2 \times 10^{-6}$ & $1.8 \times 10^{-5}$ & --- & -- & $2.5 \times 10-5$ & $2.1 \times 10^{-4}$ & $\cdots$ & $\cdots$ \\
\hline $\begin{array}{l}\text { Total Composite } \\
\text { Individual }\end{array}$ & $4.1 \times 10^{-6}$ & $2.1 \times 10^{-5}$ & $1.3 \times 10^{-5}$ & $\cdots$ & $3.7 \times 10^{-5}$ & $2.8 \times 10^{-4}$ & $3.2 \times 10^{-5}$ & $\cdots$ \\
\hline \multicolumn{9}{|l|}{60 Co } \\
\hline $\begin{array}{l}\text { Imaldtion } \\
\text { Private family } \\
\text { Owelling }\end{array}$ & $9.6 \times 10=7$ & -- & $8.0 \times 10^{-6}$ & $\cdots$ & $2.0 \times 10^{-6}$ & -- & $1.7 \times 10-5$ & --- \\
\hline Inc ineration & $1.9 \times 10^{-9}$ & --- & $1.6 \times 10^{-8}$ & $\cdots$ & $4.1 \times 10^{-9}$ & $\cdots$ & $3.4 \times 10^{-8}$ & $\ldots$ \\
\hline Direct From Hands & $2.9 \times 10^{-9}$ & $\cdots$ & $2.4 \times 10^{-3}$ & $\cdots$ & $8.2 \times 10^{-9}$ & -- & $6.8 \times 10^{-8}$ & -- \\
\hline Ingest ion & $1.0 \times 10^{-5}$ & $\cdots$ & $\cdots$ & $\cdots$ & $1.0 \times 10^{-5}$ & -- & $\cdots$ & $\cdots$ \\
\hline $\begin{array}{l}\text { Total Composite } \\
\text { Ind iviofual }\end{array}$ & $1.1 \times 10^{-5}$ & $\cdots$ & $3.0 \times 10^{-6}$ & $\cdots$ & $1.2 \times 10^{-5}$ & $\cdots$ & $1.7 \times 10^{-5}$ & $\cdots$ \\
\hline \multicolumn{9}{|l|}{$63{ }_{\mathrm{Ni}}$} \\
\hline $\begin{array}{l}\text { Inhalation } \\
\text { Private Family } \\
\text { Wrelling }\end{array}$ & $2.9 \times 10^{-8}$ & $1.8 \times 10^{-7}$ & $6.0 \times 10^{-8}$ & $\cdots$ & $9.1 \times 10^{-8}$ & $7.0 \times 10^{-7}$ & $6.0 \times 10-8$ & $\cdots$ \\
\hline Incineration & $5.6 \times 10^{-11}$ & $3.5 \times 10^{-1[1}$ & $1.2 \times 10^{-10}$ & $\cdots$ & $1.8 \times 10^{.10}$ & $1.4 \times 10^{-9}$ & $1.2 \times 10^{-10}$ & $\cdots$ \\
\hline Direct from hands & $2.7 \times 10^{-11}$ & $3.6 \times 10^{-11}$ & $3.9 \times 10^{-10}$ & $\cdots$ & $2 . B \times 10^{-10}$ & $2.1 \times 10^{-9}$ & $1.9 \times 10^{-10}$ & $\cdots$ \\
\hline Ingestion & $2.4 \times 10^{-7}$ & $2.0 \times 10^{-6}$ & $\cdots$ & -- & $8.4 \times 10^{-?}$ & $7.0 \times 10^{-6}$ & $\cdots$ & $\cdots$ \\
\hline Total Composite & $2.7 \times 10^{-7}$ & $2.2 \times 10.6$ & $6.0 \times 10-8$ & $\cdots$ & $9.3 \times 10^{-7}$ & $7.7 \times 10^{-6}$ & $6.0 \times 10^{-8}$ & -- \\
\hline
\end{tabular}




\section{TABLE 3.3-4. Collective Dose to the Composite Population Group from Surface Contamination - Industrial Source Material Transportation Containers (a) (at $10^{-5} \mu \mathrm{Ci} / \mathrm{cm}^{2}$ for $\alpha$ and $10^{-4} \mu \mathrm{Ci} / \mathrm{cm}^{2}$ for $\left.\beta-\gamma\right)$}

\begin{tabular}{|c|c|c|c|c|c|c|c|c|}
\hline \multirow[b]{2}{*}{ Radionuclide/Pathway } & \multicolumn{4}{|c|}{ Fjoft-Year Dose Equivalent (man-rem) } & \multicolumn{4}{|c|}{$\frac{50-Y e a r}{\text { Weighted Comnitted Dose Equivalent (man-ren) }}$} \\
\hline & \multirow[t]{2}{*}{$\begin{array}{l}\text { Weighted } \\
\text { Total Body }\end{array}$} & \multirow[t]{2}{*}{ Bone } & \multirow[t]{2}{*}{ Lung } & \multirow[t]{2}{*}{ Thyroid } & \multirow[t]{2}{*}{$\begin{array}{l}\text { Weighted } \\
\text { Total Body }\end{array}$} & \multirow[t]{2}{*}{ Bone } & \multirow[t]{2}{*}{ Lung } & \multirow[t]{2}{*}{ Thyroid } \\
\hline $241 \mathrm{Am}$ & & & & & & & & \\
\hline $\begin{array}{l}\text { Inhalation } \\
\text { Private Family } \\
\text { Dwelling }\end{array}$ & $1.7 \times 10^{-5}$ & $2.2 \times 10^{-5}$ & $1.2 \times 10^{-4}$ & $--(c)$ & $3.7 \times 10^{-5}$ & $9.4 \times 10^{-4}$ & $3.1 \times 10^{-4}$ & $---(c)$ \\
\hline Inc ineration & $1.5 \times 10-7$ & $1.8 \times 10^{-7}$ & $1.1 \times 30-6$ & $\cdots$ & $1.3 \times 10^{-6}$ & $8.3 \times 10^{-6}$ & $2.7 \times 10^{-6}$ & $\ldots$ \\
\hline Direct from Hands & $5.0 \times 10^{-8}$ & $6.1 \times 10^{-7}$ & $3.6 \times 10^{-7}$ & $\cdots$ & $4.4 \times 10^{-7}$ & $2.8 \times 10^{-6}$ & $9.0 \times 10^{-7}$ & --- \\
\hline Ingest ion & $2.3 \times 10^{-8}$ & $1.9 \times 10^{-7}$ & ... & $\cdots$ & $9.0 \times 10^{-7}$ & $7.5 \times 10^{-6}$ & $\cdots$ & $\cdots$ \\
\hline $\begin{array}{l}\text { Total Composite } \\
\text { Population }\end{array}$ & $1.7 \times 10^{-5}$ & $2.1 \times 10^{-5}$ & $1.2 \times 10^{-4}$ & --- & $4.0 \times 10^{-5}$ & $9.6 \times 10^{-4}$ & $3.1 \times 10^{-4}$ & --- \\
\hline \multicolumn{9}{|l|}{$90 S r-90_{Y}$} \\
\hline $\begin{array}{l}\text { Inhalation } \\
\text { Private Family } \\
\text { Duelling }\end{array}$ & $1.6 \times 10^{-6}$ & $3.2 \times 10^{-6}$ & $1.3 \times 10^{-5}$ & $\cdots$ & $1,2 \times 10^{-5}$ & $7.0 \times 10^{-5}$ & $3.2 \times 10^{-5}$ & $-\cdots$ \\
\hline Incineration & $1.8 \times 10^{-8}$ & $2.8 \times 10^{-8}$ & $1.2 \times 10^{-7}$ & -- & $1.1 \times 10^{-7}$ & $6.5 \times 10^{-7}$ & $2.9 \times 10^{-7}$ & $\cdots$ \\
\hline Direct from Hands & $5.9 \times 10^{-9}$ & $9.5 \times 10^{-9}$ & $4.0 \times 10^{-8}$ & $\cdots$ & $3.8 \times 10^{-8}$ & $2.2 \times 10^{-7}$ & $9.5 \times 10^{-8}$ & $\cdots$ \\
\hline Ingest ion & $2.2 \times 10-6$ & $1.8 \times 10^{-5}$ & $\cdots$ & $\ldots$ & $2.5 \times 10^{-5}$ & $2.1 \times 10^{-4}$ & -- & -- \\
\hline $\begin{array}{l}\text { Tota' Composise } \\
\text { Population }\end{array}$ & $3.8 \times 10^{-6}$ & $2.1 \times 10^{-5}$ & $1.3 \times 10^{-5}$ & $\cdots$ & $3.7 \times 10^{-5}$ & $2.8 \times 10^{-4}$ & $3.2 \times 10^{-5}$ & -- \\
\hline \multicolumn{9}{|l|}{${ }^{60} \mathrm{Co}_{0}$} \\
\hline $\begin{array}{l}\text { Inhalation } \\
\text { Private } \mathbf{F a m i l y} \\
\text { Derelling }\end{array}$ & $9.6 \times 10^{-7}$ & --- & $8.0 \times 10^{-6}$ & $\cdots$ & $2.0 \times 10^{-6}$ & $\cdots$ & $1.7 \times 10^{-5}$ & --- \\
\hline Incineration & $8.9 \times 10-9$ & -- & $7.4 \times 10^{-8}$ & -- & $1.9 \times 10^{-8}$ & $\cdots$ & $1.6 \times 10^{-7}$ & $\cdots$ \\
\hline Direct from Hands & $2.9 \times 10.9$ & -- & $2.4 \times 10^{-8}$ & $\cdots$ & $8.2 \times 10^{-9}$ & $\cdots$ & $6.8 \times 10^{-8}$ & $\cdots$ \\
\hline Ingestion & $1.0 \times 10^{-5}$ & --- & -- & -- & $1.0 \times 10^{-5}$ & -- & $\cdots$ & $\cdots$ \\
\hline $\begin{array}{l}\text { Total Composite } \\
\text { Population }\end{array}$ & $1.1 \times 10^{-5}$ & $\cdots$ & $8.1 \times 10-6$ & -- & $1.2 \times 10^{-5}$ & --- & $1.7 \times 10^{-5}$ & -- \\
\hline \multicolumn{9}{|l|}{$63^{\mathrm{Ni}}$} \\
\hline \multicolumn{9}{|l|}{ Inhalation } \\
\hline $\begin{array}{l}\text { Priyate Fanily } \\
\text { Dwelling }\end{array}$ & $2.9 \times 10-8$ & $1.8 \times 10^{-7}$ & $6.0 \times 10-8$ & --- & $9.1 \times 10-8$ & $7.0 \times 10-7$ & $6.0 \times 10-8$ & --- \\
\hline Incineration & $2.6 \times 10^{-i c}$ & $1.6 \times 10^{-9}$ & $5.8 \times 10^{-10}$ & $-\cdot$ & $8.1 \times 10^{-10}$ & $6.2 \times 10^{-9}$ & $5.8 \times 10^{-10}$ & --- \\
\hline Direct from Hands & $2.7 \times 10^{-11}$ & $3.6 \times 10^{-11}$ & $1.9 \times 0^{-10}$ & $\cdots$ & $2.8 \times 10^{-10}$ & $2.1 \times 10^{-9}$ & $1.9 \times 10^{-10}$ & $\cdots$ \\
\hline Ingest inr: & $2.4 \times 10^{-7}$ & $2.0 \times 10-6$ & $\ldots$ & $\cdots$ & $8.4 \times 10^{-7}$ & $7.0 \times 10^{-6}$ & $\cdots$ & +- \\
\hline $\begin{array}{l}\text { Total Composite } \\
\text { Populdtion }\end{array}$ & $2.7 \times 10^{-1}$ & $2.2 \times 10^{-6}$ & $6.1 \times 10-8$ & -- & $9.3 \times 1.07$ & $7.7 \times 10-6$ & $6.1 \times 10^{-8}$ & $\cdots$ \\
\hline \multicolumn{9}{|c|}{ 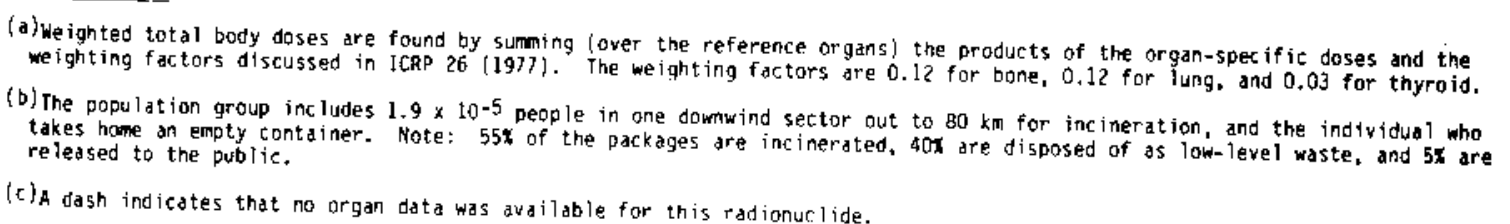 } \\
\hline
\end{tabular}


worker. Radiation doses to members of the public are listed in Tables 3.3-3 and 3.3-4. The calculated radiation dose to a composite individual in the public is listed in Table 3.3-3, and the dose to the exposed population group is listed in Table 3.3-4. The radiation doses to the public are controlled by the dose from the $5 \%$ of the empty containers that are assumed to be released to the public. By comparison, only a small fraction of the total population dose comes from the $55 \%$ of the containers that are assumed to be incinerated.

A preliminary calculation for ${ }^{60} \mathrm{Co}_{0}$ indicated that the dose from direct exposure defined in the exposure scenarios is about three orders of magnitude lower than the doses from inhalation and ingestion for all of the radionuclides considered. Thus, the doses from direct exposure to industrial source surface contamination are omitted from these tables.

The dose calculations are performed for ${ }^{241} \mathrm{Am},{ }^{90} \mathrm{Sr}$, and ${ }^{60} \mathrm{Co}$ to demonstrate the dose relationships for alpha, beta, and gamma emitters, respectively. As a comparison, the dose from ${ }^{63} \mathrm{Ni}$ is calculated to show the dose response of a less-toxic beta emitter. As shown by the data in Tables 3.3-2 through 3.3-4, the doses from ${ }^{63} \mathrm{Ni}$ are about an order of magnitude less than those from ${ }^{90} \mathrm{Sr}$.

\subsection{Nuclear Fuel Cycle Materials}

Transportation of nuclear fuel cycle materials includes the shipment of $\mathrm{U}_{3} \mathrm{O}_{8}, \mathrm{UF}_{6}$, fresh fuel, and spent fuel. The radionuclides of concern in the fuel cycle range from the isotopes of uranium in fresh fuel to a complex mixture of fission products and transuranics found in spent fuel. A listing of typical radionuclides found in nuclear fuel cycle materials is given in Table 3.4-1 (Oak, et al. 1980; Schnejder and Jenkins 1977). This table also contains the physical half-life for each radionuclide. It is difficult to determine the exact physical or chemical form of the radionuclides found on the surface of containers used to ship fuel cycle material. For $\mathrm{U}_{3} \mathrm{O}_{8}, \mathrm{UF}_{6}$, and fresh fuel shipments, 
the surface contamination is assumed to be ${ }^{238} \mathrm{U}$ since the fuel is only slightly ( 3 to 4 percent) enriched. For spent fuel, we have based the dose calculations on the representative mixture of radionuclides shown in Table 3.4-1. The fractional contribution of each radionuclide to the total mixture is also shown. The mixture is divided into two groups for the dose calculations: beta-gamma emitters and alpha emitters. This

TABLE 3.4-1. Common Nuclear Fuel Cycle Radionuclides(a)

\begin{tabular}{|c|c|c|c|c|c|}
\hline Radionuclide & $\begin{array}{l}\text { Physical } \\
\text { Half-Life } \\
\text { (Years) }\end{array}$ & $\begin{array}{l}\text { Fraction } \\
\text { Activity }\end{array}$ & Radionuclide & $\begin{array}{l}\text { Physical } \\
\text { Half-Life } \\
\text { (Years) }\end{array}$ & $\begin{array}{l}\text { Fraction } \\
\text { Activity } \\
\end{array}$ \\
\hline $3_{H}$ & $1.2 \times 10^{1}$ & $\ldots(c)$ & ${ }^{129 m_{\mathrm{Te}}}$ & $9.3 \times 10^{-2}$ & $3.0 \times 10^{-3}$ \\
\hline $32 p$ & $3.8 \times 10^{-2}$ & $1.5 \times 10^{-2}$ & $131_{I}$ & $2.2 \times 10^{-2}$ & $3.8 \times 10^{-1}$ \\
\hline${ }^{51} \mathrm{Cr}$ & $7.6 \times 10^{-2}$ & $3.8 \times 10^{-1}$ & ${ }^{134} \mathrm{Cs}$ & $2.0 \times 10^{0}$ & $2.2 \times 10^{-3}$ \\
\hline${ }^{54} \mathrm{Mn}$ & $8.3 \times 10^{-1}$ & $4.5 \times 10^{-3}$ & ${ }^{136} \mathrm{Cs}$ & $3.8 \times 10^{-2}$ & $1.5 \times 10^{-5}$ \\
\hline${ }^{55} \mathrm{Fe}$ & $2.6 \times 10^{0}$ & $7.5 \times 10^{-2}$ & ${ }^{137} \mathrm{Cs}$ & $3.0 \times 10^{1}$ & $5.2 \times 10^{-3}$ \\
\hline${ }^{59} \mathrm{Fe}$ & $1.2 \times 10^{-1}$ & $2.2 \times 10^{-3}$ & $140_{\mathrm{Ba}}$ & $3.6 \times 10^{-2}$ & $3.0 \times 10^{-2}$ \\
\hline${ }^{58} \mathrm{Co}$ & $2.0 \times 10^{-1}$ & $1.5 \times 10^{-2}$ & ${ }^{140} \mathrm{La}(b)$ & $4.6 \times 10^{-3}$ & $3.0 \times 10^{-2}$ \\
\hline${ }^{60} \mathrm{Co}$ & $5.3 \times 10^{0}$ & $3.0 \times 10^{-2}$ & ${ }^{141} \mathrm{Ce}$ & $8.8 \times 10^{-2}$ & $2.2 \times 10^{-3}$ \\
\hline${ }^{63} \mathrm{Ni}$ & $9.2 \times 10^{\top}$ & $7.5 \times 10^{-5}$ & ${ }^{144} \mathrm{Ce}$ & $7.7 \times 10^{-1}$ & $3.0 \times 10^{-3}$ \\
\hline${ }^{65} \mathrm{Zn}$ & $6.7 \times 10^{-1}$ & $1.5 \times 10^{-2}$ & ${ }^{143} \mathrm{Pr}$ & $3.8 \times 10^{-2}$ & $3.0 \times 10^{-3}$ \\
\hline${ }^{89} \mathrm{Sr}$ & $1.4 \times 10^{-1}$ & $7.5 \times 10^{-3}$ & ${ }^{147} \mathrm{Nd}$ & $3.0 \times 10^{-2}$ & $2.2 \times 10^{-4}$ \\
\hline${ }^{90} \mathrm{Sr}$ & $2.8 \times 10^{1}$ & $4.5 \times 10^{-4}$ & $235 \mathrm{U}$ & $7.1 \times 10^{8}$ & $\ldots$ (d) \\
\hline $90_{Y}(b)$ & $7.3 \times 10^{-3}$ & $4.5 \times 10^{-4}$ & $238_{U}$ & $4.5 \times 10^{9}$ & - (d) \\
\hline $91_{Y}$ & $1.6 \times 10^{-1}$ & $3.0 \times 10^{-3}$ & ${ }^{238} \mathrm{Pu}$ & $8.6 \times 10^{1}$ & $\ldots$ (d) \\
\hline${ }^{95} \mathrm{Zr}$ & $1.8 \times 10^{-1}$ & $5.2 \times 10^{-4}$ & ${ }^{239} \mathrm{Pu}$ & $2.4 \times 10^{4}$ & $-{ }_{-}(d)$ \\
\hline${ }^{103} \mathrm{Ru}$ & $1.1 \times 10^{-1}$ & $1.5 \times 10^{-3}$ & ${ }^{241} \mathrm{Pu}$ & $1.3 \times 10^{1}$ & $\ldots$ (d) \\
\hline${ }^{106} \mathrm{Ru}$ & $1.0 \times 10^{0}$ & $2.2 \times 10^{-4}$ & ${ }^{241_{A m}}$ & $4.6 \times 10^{2}$ & $\ldots$ (d) \\
\hline $110 \mathrm{~m}_{\mathrm{Ag}}$ & $6.8 \times 10^{-1}$ & $7.5 \times 10^{-5}$ & ${ }^{244} \mathrm{Cm}$ & $1.8 \times 10^{1}$ & $\ldots$ (d) \\
\hline
\end{tabular}

(a) Based on the radionuclides 1 isted in Table 5.2-8 from 0ak et al. 1980, and selected radionuclides from Table 5.1-1 from Schneider and Jenkins 1977.

(b) Short-lived daughter of parent with same mass number.

(c) ${ }^{3} H$ is not included in the total.

(d) This radionuclide is present in reactor fuel, but it is not found in measurable quantities in reactor coolant water. The alpha mixture considered in the dose calculations is $90 \% 238 \mathrm{U}$ and $10 \% 239 \mathrm{Pu}$. 
is done so that representative doses will result for spent fuel shipments. Thus, the doses are not based on the most toxic radionuclides, but rather they are based on a reference mixture. Radiation doses from surface contamination on nuclear fuel cycle materials containers are calculated in the following sections. First, reference containers are defined for $\mathrm{U}_{3} \mathrm{O}_{8}, \mathrm{UF}_{6}$, fresh fuel, and spent fuel. Using these reference containers, radiation exposure scenarios are developed and radiation doses are calculated in the following sections.

\subsubsection{Reference Nuclear Fuel Cycle Materials Containers}

An overview of the types of containers used to transport nuclear fue 1 cycle materials is given in a document by Rhoads (1977). Uranium ore concentrate in the form of $U_{3} 0_{8}$ classifies as Low Specific Activity (LSA) material requiring only strong, tight, industrial packaging in exclusive use vehicles. A standard steel drum is defined to be the reference $\mathrm{U}_{3} \mathrm{O}_{8}$ container with a volume of $0.21 \mathrm{~m}^{3}$ (55 gallons) and a surface area on about $2.3 \mathrm{~m}^{2}$. Uranium hexafluoride (UF ${ }_{6}$ ) is shipped from conversion plants to the gaseous diffusion plant for enrichment, then enriched UF ${ }_{6}$ is shipped to fuel fabrication plants. Natural UF 6 is classified as LSA material, and the reference container is defined to be a 9-metric ton cylindrical container with an approximate surface area of $11 \mathrm{~m}^{2}\left(120 \mathrm{ft}^{2}\right)$. Enriched $\mathrm{UF}_{6}$ is classified as fissile material and is shipped in quantities that require Type B containers. The reference 9metric ton container used for natural $U_{6}$ is also assumed to be used for enriched $U_{6}$ with the addition of an overpack. Fresh fuel elements are assumed to be shipped in protective Type $B$ outer containers. These containers are cylindrical in shape with an approximate surface area of $15 \mathrm{~m}^{2}\left(160 \mathrm{ft}^{2}\right)$. Spent nuclear fuel contains residual ${ }^{235} \mathrm{U}$ (about $0.9 \%$ ), ${ }^{238} \mathrm{U}$, plutonium isotopes, and highly radioactive fission products. Spent fuel casks are large and very massive since they must provide shielding from both gamma-rays and neutrons, and heat removal. These casks are classified as Type B containers and weigh about 22 
metric tons empty. The surface area of the reference cask is approximately $26 \mathrm{~m}^{2}\left(280 \mathrm{ft}^{2}\right)$. These reference containers are selected as being representative of the containers used in industry today, and no further effort is made to model the specific differences found in container design.

\subsubsection{Nuclear Fuel Cycle Materials Radiation Exposure Scenarios} Radiation exposure scenarios are defined in this section for nuclear fuel cycle materials. Since the containers used in the nuclear fuel cycle are recycled, that is they are not released for public use, no public exposure pathways involving contact with the containers exist. Also, exclusive use shipments exclude contact by members of the pubtic. However, a limited population group is assumed to contact the vehicle after the shipment, and they ingest a small fraction of contamination on the vehicle. Total occupational dose is estimated by multiplying the dose to composite individual worker by four, assuming that four workers are equally exposed. This is done to account for the possibility that more than four workers may be exposed, but that they receive less dose than the composite individual worker defined in this study. The following sections contain the radiation exposure scenarios used in dose calculations for nuclear fuel cycle materials.

\subsubsection{Direct Ingestion}

Transportation workers are assumed to ingest surface contamination from $5 \times 10^{-5} \mathrm{~m}^{2}$ of surface for each container. No direct ingestion by members of the public occurs since all of the containers are recycled and materials are shipped as exclusive use, but secondary ingestion could occur if food products or people come in contact with a truck surface after it has been in contact with a container. The dose to a limited population group (10 people for each category of container) is calculated assuming that they ingest the contamination from a total surface area of: $2.4 \times 10^{-3} \mathrm{~m}^{2}$ for $\mathrm{U}_{3} 0_{8}$ stee 1 drums, $1.1 \times 10^{-2} \mathrm{~m}^{2}$ for $\mathrm{UF}_{6}$ shipments, $1.5 \times 10^{-2} \mathrm{~m}^{2}$ for fresh fuel shipments, and $2.6 \times 10^{-2} \mathrm{~m}^{2}$ for 
spent fuel shipments. These numbers are for possible secondary pathways and are found by multiplying the surface area of each container by $1 \times 10^{-3} \mathrm{~m}^{2}$ per $\mathrm{m}^{2}$ of surface. It is assumed that the containers for all shipments, except for spent fuel shipments, are double stacked, and thus only $50 \%$ are in contact with truck surfaces.

\subsubsection{Inhalation}

The local air concentrations for workers are found for each container using Equation 3.1. Where $\Omega$ equals the surface contamination level (in $\left.\mathrm{Ci} / \mathrm{m}^{2}\right)$, the resulting air concentrations in the shipping or receiving room are calculated to be: $\left[1.4 \times 10^{-6} \cdot \Omega\right]$ for $\mathrm{U}_{3} \mathrm{O}_{8}$ drums, $\left[6.9 \times 10^{-6} \cdot \Omega\right]$ for $\mathrm{UF}_{6}$ containers, $\left[9.4 \times 10^{-6} \cdot \Omega\right]$ for fresh fue $]$ containers, and $\left[1.6 \times 10^{-5} \cdot \Omega\right]$ for spent fuel containers. The calculated air concentration inside a closed transport vehicle for $\mathrm{U}_{3} \mathrm{O}_{8}$ drums is $\left[2 \times 10^{-6} \cdot \Omega\right]$. Since all of these containers are recycled, that is none are released to the public, there is no inhalation exposure to members of the public. For direct inhalation from hands, workers are the only ones in contact with the containers, and they are assumed to inhale the equivalent of $5 \times 10^{-5} \mathrm{~m}^{2}$ of surface contamination.

\subsubsection{Direct Exposure}

Since none of the nuclear fuel cycle materials containers considered in this study are released for public use, only transportation workers are exposed. Dose to workers from surface contamination is calculated assuming that each worker spends 30 minutes at an average of $1 \mathrm{~m}$ from each type of container.

\subsubsection{Radiation Doses from Nuclear Fuel Cycle Materials Transportation Containers}

The results of radiation dose calculations performed for the surface contamination scenarios defined for nuclear fuel cycle materials transportation containers are presented in Tables 3.4-2 through 3.4-5. These doses are calculated based on current DOT contamination limits (i.e. 
$1 \times 10^{-4} \mu \mathrm{Ci} / \mathrm{Cm}^{2}$ for beta-gamma emitting radionuclides, and $1 \times 10^{-5} \mu \mathrm{Ci} / \mathrm{Cm}^{2}$ for alpha emitting radionuclides). The doses in Tables 3.4-2 through 3.4-5 are calculated for ingestion and inhalation only. A preliminary calculation for the direct exposure pathway resulted in doses that were about three orders of magnitude less than the doses from inhalation or ingestion for all radionucides. Therefore, they have been omitted from all of the dose tables for fuel cycle materials.

Tables 3.4-2 and 3.4-3 contain the doses calculated for shipments that contain uranium in either natural or enriched forms. The doses are calculated using ${ }^{238} U$ for $U_{3} 0_{8}$, UF 6 , and fresh fuel shipments. Table 3.4-2 contains the dose to a composite worker and an estimate of the composite collective occupational dose based on the assumption that the total is four times larger than the dose to a composite worker. This assumption is made based on current information from industry, and accounts for the dose to a greater number of workers who receive less dose than the composite worker.

Since none of the transportation containers are released after their use and most shipments are exclusive use, no exposure pathways to a composite individual in the public are defined. The dose to a limited population group exposed after the shipment by contact with the vehicle is calculated by assuming that 10 people ingest a small fraction of the surface contamination that is transferred to truck surfaces. This is done to account for all secondary ingestion pathways that could involve members of the public. The doses obtained by this analys is may be conservatively large, but they should provide a basis for comparison with other doses in this study.

As a spent fuel cask drys after decontamination, the surface contamination level may increase by a process known as sweating. Such behavior is a complex function of many conditions including the specific cask 


\section{TABLE 3.4-2. Individual and Collective Doses to Composite Workers from Surface Contamination - Nuclear Fuel Cycle Materials Transportation Containers - $238 \mathrm{U}$ (at $10^{-4} \mu \mathrm{Ci} / \mathrm{cm}^{2}$ for $235 \mathrm{U}$ Natural and $10^{-5} \mu \mathrm{Cj} / \mathrm{cm}^{2}$ for Fresh Fuel)}

\begin{tabular}{|c|c|c|c|c|c|c|c|c|}
\hline \multirow[b]{2}{*}{ Radionuclide/Pathway } & \multicolumn{4}{|c|}{ First-Year Dose Equivalent (rem) } & \multicolumn{4}{|c|}{ 50y fear Committed Dose Equivalent (rem) } \\
\hline & $\begin{array}{l}\text { Welghted } \\
\text { Iotd Body }\end{array}$ & Bone & Lung & Thyroid & $\begin{array}{l}\text { Welohted } \\
\text { Total Body }\end{array}$ & Bone & Lung & Thyroid \\
\hline \multicolumn{9}{|l|}{$238_{u}-v_{3} 0_{g}$} \\
\hline $\begin{array}{l}\text { Inhalation } \\
\text { Load ing/ Un loading }\end{array}$ & $1.7 \times 10^{-5}$ & $4.2 \times 10^{-6}$ & $1.4 \times 10^{-4}$ & $\ldots(b)$ & $4.2 \times 10^{-5}$ & $8.1 \times 10^{-6}$ & $3.4 \times 10^{-4}$ & $\ldots(a)$ \\
\hline Closed Vehicle & $2.4 \times 10^{-5}$ & $6.1 \times 10^{-6}$ & $2.0 \times 10^{-4}$ & $\cdots$ & $6.0 \times 10^{-5}$ & $1.2 \times 10^{-5}$ & $4.9 \times 10^{-4}$ & $\cdots$ \\
\hline Direct from Hands & $3.2 \times 10^{-7}$ & $8.5 \times 10^{-8}$ & $2.7 \times 10^{-6}$ & $\cdots$ & $8.4 \times 10^{-7}$ & $1.6 \times 10^{-7}$ & $6.8 \times 10^{-6}$ & -- \\
\hline ingestion & $2.6 \times 10^{-6}$ & $2.2 \times 10^{-5}$ & -- & -- & $4.6 \times 10^{-6}$ & $3.8 \times 10^{-5}$ & -- & $\cdots$ \\
\hline $\begin{array}{l}\text { Total Composite } \\
\text { Worker }\end{array}$ & $4.4 \times 10^{-5}$ & $3.2 \times 10-5$ & $3.4 \times 10^{-4}$ & $\cdots$ & $1.1 \times 10^{-4}$ & $5.8 \times 10^{-5}$ & $8.4 \times 10^{-4}$ & $\cdots$ \\
\hline $\begin{array}{l}\text { Total Occupational(b) } \\
(\text { man-rem) }\end{array}$ & $1.8 \times 10^{-4}$ & $1.3 \times 10^{-4}$ & $1.4 \times 10^{-4}$ & $-\cdot$ & $4.3 \times 10^{-4}$ & $2.3 \times 10^{-4}$ & $3.6 \times 10^{-3}$ & -- \\
\hline \multicolumn{9}{|l|}{$238_{U}$-Natura 1 UF $_{6}$} \\
\hline \multicolumn{9}{|l|}{ Inmalation } \\
\hline Loading/Unloading & $8.8 \times 10^{-5}$ & $2.2 \times 10^{-5}$ & $7.1 \times 10^{-4}$ & $\cdots$ & $1.0 \times 10^{-5}$ & $4.2 \times 10^{-5}$ & $1.8 \times 10^{-3}$ & $\cdots$ \\
\hline Direct from Hands & $3.3 \times 10^{-7}$ & $8.5 \times 10^{-8}$ & $2.7 \times 10^{-6}$ & $\cdots$ & $8.4 \times 10^{-7}$ & $1.6 \times 10^{-7}$ & $6.8 \times 10^{-6}$ & $+\cdots$ \\
\hline Ingestion & $2.6 \times 10^{-6}$ & $2.2 \times 10^{-5}$ & --- & $\cdots$ & $4.6 \times 10^{-6}$ & $3.8 \times 10^{-5}$ & $\cdots$ & $\cdots$ \\
\hline $\begin{array}{l}\text { Iotal Compos ite } \\
\text { Worker }\end{array}$ & $9.1 \times 10^{-5}$ & $4.4 \times 10^{-5}$ & $7.1 \times 10^{-4}$ & $\cdots$ & $1.5 \times 10^{-5}$ & $8.0 \times 10^{-5}$ & $1.8 \times 10^{-3}$ & $\cdots$ \\
\hline $\begin{array}{l}\text { Total Occupationaif }(b] \\
(\text { man-rem) }\end{array}$ & $3.6 \times 12^{-4}$ & $1.8 \times 10^{-4}$ & $2.8 \times 10^{-3}$ & $\cdots$ & $6.2 \times 10^{-5}$ & $3.2 \times 10^{-4}$ & $7.2 \times 10^{-3}$ & $\cdots$ \\
\hline \multicolumn{9}{|l|}{$238_{U}$-Enriched $U F_{6}$} \\
\hline \multicolumn{9}{|l|}{ Inhalation } \\
\hline Loading/Un loading & $8.8 \times 10^{-6}$ & $2.2 \times 10^{-6}$ & $7.1 \times 10^{-5}$ & --- & $1.0 \times 10^{-6}$ & $4.2 \times 10^{-6}$ & $1.8 \times 10^{-4}$ & $\cdots$ \\
\hline Direct from Mands & $3.3 \times 10^{-8}$ & $8.5 \times 10^{-9}$ & $2.7 \times 10^{-7}$ & $-\cdots$ & $8.4 \times 10^{-8}$ & $1.6 \times 10^{-8}$ & $6.8 \times 10^{-7}$ & --- \\
\hline Ingest ion & $2.6 \times 10^{-7}$ & $2.2 \times 10^{-6}$ & -- & $\cdots$ & $4.6 \times 10^{-7}$ & $3.8 \times 10^{-6}$ & --- & $\ldots$ \\
\hline $\begin{array}{l}\text { Total Composite } \\
\text { Worker }\end{array}$ & $9.1 \times 10^{-6}$ & $4.4 \times 10^{-6}$ & $7.1 \times 10^{-5}$ & $\cdots$ & $1.5 \times 10^{-6}$ & $8.0 \times 10^{-6}$ & $1.8 \times 10^{-4}$ & -- \\
\hline $\begin{array}{l}\text { Total occupat iona } \mathrm{r}^{(b)} \\
(\text { man-rem) }\end{array}$ & $3.6 \times 10^{-5}$ & $1.8 \times 10^{-5}$ & $2.8 \times 10^{-4}$ & $\cdots$ & $6.2 \times 10^{-6}$ & $3.2 \times 10^{-5}$ & $7.2 \times 10^{-4}$ & $\cdots$ \\
\hline \multicolumn{9}{|l|}{$238_{\text {U-Fresh Fue } 1}$} \\
\hline $\begin{array}{l}\text { Inhalation } \\
\text { Loadingfun loading }\end{array}$ & $1.2 \times 10^{-5}$ & $2.9 \times 10^{-6}$ & $9.3 \times 10^{-5}$ & $\cdots$ & $2.8 \times 10^{-5}$ & $5.6 \times 10^{-6}$ & $2.3 \times 10^{-4}$ & $\cdots$ \\
\hline Direct from Hands & $3.3 \times 10^{-8}$ & $8.5 \times 10^{-9}$ & $2.7 \times 10^{-7}$ & $-\cdots$ & $8.4 \times 10^{-8}$ & $1.6 \times 10^{-8}$ & $6.8 \times 10^{-7}$ & $\cdots$ \\
\hline Jngestion & $2.6 \times 10^{-7}$ & $2.2 \times 10^{-6}$ & $\cdots$ & $\cdots$ & $4.6 \times 10^{-7}$ & $3.8 \times 10^{-6}$ & $\cdots$ & -- \\
\hline $\begin{array}{l}\text { Total Composite } \\
\text { Worker }\end{array}$ & $1.2 \times 10^{-5}$ & $5.1 \times 10^{-6}$ & $9.3 \times 10^{-5}$ & -- & $2.8 \times 10^{-5}$ & $9.4 \times 10^{-6}$ & $2.3 \times 10^{-4}$ & $\ldots$ \\
\hline $\begin{array}{l}\text { Total Oecupationa }(0) \\
\text { (man-rem) }\end{array}$ & $4.9 \times 10^{-5}$ & $2.0 \times 10^{-6}$ & $3.7 \times 10^{-4}$ & $\cdots$ & $1.1 \times 10^{-4}$ & $3.8 \times 10^{-5}$ & $9.2 \times 10^{-4}$ & $\cdots$ \\
\hline
\end{tabular}


TABLE 3.4-3. Collective Dose to the Composite Population Group from Surface Contamination - Nyclear Fuel Cycle Mąterials Transportation
Containers - $238 \mathrm{U}$ (a) (at $10^{-4} \mathrm{\mu C} / \mathrm{cm}^{2}$ for $238 \mathrm{U}$ Natural and $10^{-5}$ $\mu \mathrm{Ci} / \mathrm{cm}^{2}$ for fresh fuel)

\section{Weighted fot -Year Dose Equivalent (man-rem)}

Material Form
$\mathrm{U}_{3} 0_{8}$
Uf $_{6}$-Natura?

\section{Total Booy}

$1.6 \times 10^{-4}$

$7.2 \times 10^{-4}$

$7.2 \times 10^{-5}$

$9.6 \times 10^{-5}$

Bone

$1.3 \times 10^{-3}$

$6.0 \times 10^{-3}$

$6.0 \times 10^{-4}$

8. $0 \times 10^{-4}$

\begin{tabular}{l} 
Lung \\
\hline$\ldots(c)$ \\
$\ldots$ \\
$\ldots$ \\
$\ldots$
\end{tabular}

Thyroid

50-Ygar Committed Dose Equivalent (man-rem) Weighted (t) Tota] Body

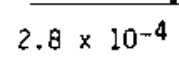

Bone

$-.-(c)$

$1.3 \times 10^{-3}$

$2.3 \times 10^{-3}$

L. Lung Thyroid

Fresh Fue 1

$$
9.6 \times 10-5
$$

(a) The composite population group consists of 10 people who ingest a total of $1.2 \times 10^{-2} \mathrm{~m}^{2}$ of surface contamination that is transferred to truck surfaces. Note: the containers are double stacked, thus only $50 \%$ are in contact with truck surfaces.

(b) Weighted total body doses are found by summing (over the reference organs) the products of the organ-specific doses and the weighting factors discussed in ICRP $26(1977)$. The weighting factors used are 0.12 for bone, 0.12 for lung, and 0.03 for thyroid

$(c)_{A}$ dash indicates that no organ data are available for this radionuclide. 
TABLE 3.4-4. Individual and Collective Doses to Composite Workers from Surface Contamination - Nuclear Fuel Cycle Materials

Transportation Containers - Spent Fuel (a) (at $10^{-5} \mu \mathrm{Ci} / \mathrm{cm}^{2}$

$\alpha$ and $10^{-4}{ }_{\mu C} \mathrm{i} / \mathrm{cm}^{2}$ for $\left.\beta-\gamma\right)$

\begin{tabular}{|c|c|c|c|c|c|c|c|c|}
\hline \multirow[b]{2}{*}{$\begin{array}{l}\text { Radionuc Tide Type } \\
\text { Pathway. }\end{array}$} & \multicolumn{4}{|c|}{ (Ejrst-Year Dose Equivalent (rem) } & \multicolumn{4}{|c|}{ 50-year Committed Dose Equivalent (rem) } \\
\hline & $\begin{array}{l}\text { Weighted } \\
\text { Total Body }\end{array}$ & Bone & Lung & Thyroid & $\begin{array}{l}\text { Weighted } \\
\text { Iotal Body }\end{array}$ & Bone & Lung & Thyroid \\
\hline \multicolumn{9}{|l|}{ Beta-Gama } \\
\hline $\begin{array}{l}\text { Inhalation } \\
\text { Loading/Un Toading }\end{array}$ & $7.5 \times 10^{-7}$ & $8.7 \times 10^{-7}$ & $5.0 \times 10^{-6}$ & $1.4 \times 10^{-6}$ & $4.1 \times 10^{-6}$ & $1.9 \times 10^{-5}$ & $1.2 \times 10^{-5}$ & $1.4 \times 10^{-6}$ \\
\hline Direct from Hands & $1.3 \times 10^{-9}$ & $1.4 \times 10^{-9}$ & $8.9 \times 10^{-9}$ & $2.3 \times 10^{-9}$ & $6.3 \times 10^{-9}$ & $3.2 \times 10^{-8}$ & $2.0 \times 10^{-8}$ & $2.3 \times 10^{-9}$ \\
\hline Ingestion & $2.6 \times 10^{-6}$ & $3.0 \times 10^{-6}$ & $--(c)$ & $7.4 \times 10^{-5}$ & $6.2 \times 10^{-6}$ & $3.2 \times 10^{-5}$ & $--(c)$ & $7.9 \times 10^{-5}$ \\
\hline $\begin{array}{l}\text { Total Composite } \\
\text { Worker }\end{array}$ & $3.4 \times 10^{-6}$ & $3.9 \times 10^{-6}$ & $5.0 \times 10^{-6}$ & $7.5 \times 10^{-5}$ & $1.0 \times 10^{-5}$ & $5.1 \times 10^{-5}$ & $1.2 \times 10^{-5}$ & $8.0 \times 10^{-5}$ \\
\hline $\begin{array}{l}\text { Total Occupational (d) } \\
\text { (man-rem) }\end{array}$ & $1.3 \times 10^{-5}$ & $1.6 \times 10^{-5}$ & $2.0 \times 10^{-5}$ & $3.0 \times 10^{-4}$ & $4.1 \times 10^{-5}$ & $2.0 \times 10^{-4}$ & $4.8 \times 10^{-5}$ & $3.2 \times 10^{-4}$ \\
\hline \multicolumn{9}{|l|}{ Alpha } \\
\hline $\begin{array}{l}\text { Inhalation } \\
\text { Loading/Un loading }\end{array}$ & $1.9 \times 10^{-5}$ & $6.1 \times 10^{-6}$ & $1.5 \times 10^{-4}$ & -- & $5.6 \times 10^{-5}$ & $8.8 \times 10^{-5}$ & $3.8 \times 10^{-4}$ & $\cdots$ \\
\hline Direct from Hands & $3.4 \times 10^{-8}$ & $1.1 \times 10^{-8}$ & $2.7 \times 10^{-7}$ & $-\cdots$ & $9.4 \times 10^{-8}$ & $1.5 \times 10^{-7}$ & $6.3 \times 10^{-7}$ & $\cdots$ \\
\hline Ingestion & $2.6 \times 10^{-7}$ & $2.6 \times 10^{-6}$ & -- & -- & $4.7 \times 10^{-7}$ & $3.9 \times 10^{-6}$ & $\cdots$ & $\cdots$ \\
\hline $\begin{array}{l}\text { Total Composite } \\
\text { Worker }\end{array}$ & $1.9 \times 10^{-5}$ & $8.7 \times 10^{-6}$ & $1.5 \times 10^{-4}$ & $\cdots$ & $5.6 \times 10^{-5}$ & $9.2 \times 10^{-5}$ & $3.8 \times 10^{-4}$ & $\cdots$ \\
\hline $\begin{array}{l}\text { Total Occupationa } 1(d) \\
(\text { man-rem) }\end{array}$ & $7.7 \times 10^{-5}$ & $3.5 \times 10^{-5}$ & $6.0 \times 10^{-4}$ & $+\cdots$ & $2.2 \times 10^{-4}$ & $3.7 \times 10^{-4}$ & $1.5 \times 10^{-3}$ & -- \\
\hline
\end{tabular}
(a) The doses shown are based on the beta-garma radionuclide mixture shown in Table 3.4-1. For alpha, a mixture of $95 \% 238 \mathrm{y}$ and $5 \%$
$2399_{\mathrm{p}}$ was assumed.

(b) Weighted total body doses are found by suming (over the reference organs) the products of the organ-specific doses and the weight ing $f$ actors are 0.12 for bone, 0.12 for lung, and 0.03 for thyroid.

(c) A dash indicates that no organ data was available for this radionuclide.

(d) Based on the assumption that the total occupational dose is four times larger than the composite worker's dose. 
TABLE 3.4-5. Collective Dose to the Composite Population Group from Surface Contamination - Nuclear Fuel Cycle Materials Transportation Containers - Spent Fuel (a) (at $10^{-5} \mu \mathrm{Ci} / \mathrm{cm}^{2}$ for $\alpha$ and $10^{-4}$ $\mu \mathrm{Ci} / \mathrm{cm}^{2}$ for $\left.\beta-\gamma\right)$ Weightedic

First-Year Dose Equivalent (man-rem) Total Body $1.2 \times 10^{-3}$

Bone

$1.2 \times 10^{-4}$

$$
\text { - }
$$$$
\frac{\text { Lung }}{\text { (d) }}
$$

Radionuclide
Type

Beta-Ganma

Alpha

(a) The composite population group consists of a group of 10 people who could ingest a total of $2.6 \times 10^{-2} \mathrm{~m}^{2}$ of surface contamination that is transferred to truck surfaces.

(b) The doses shown are based on the beta-gamma radionuclide mixture shown in Table 3.4-1. For alpha, a mixture of $95 \% 238 \mathrm{U}$ and $5 \times 239 p u$ was assumed.

(c) Weighted total body doses are found by suming (over the reference organs) the products of the organ-specific doses and the weighting factors discussed in ICRP 26 (1977). The weighting factors used are 0.12 for bone, 0.12 for lung, and 0.03 for thyroid.

(d) A dash indicates that no organ data was available for this radionuclide. 
surface design, the chemical form of the radioactive material involved, and the decontamination technique used. No attempt is made in the dose calculations to account for a possible increase in surface contamination on spent fuel casks after decontamination; since all surfaces are assumed to be at the current limits.

\subsubsection{Spent Fuel Cask Decontamination}

The impact on total collective radiation dose from decontaminating spent fuel shipping casks is discussed in this section. The following factors that influence the analysis of total collective radiation doses are considered: the total time spent decontaminating at a constant decontamination rate, the exposure rate to workers from the contents of the spent fuel cask, the reduction in population dose resulting from reduced surface contamination levels, and the decontamination factor associated with the technique used. The relative impacts of these factors on the total 50-year committed dose equivalents are shown in Figure 3.4-1 through 3.4-3. These figures contain graphs of the total 50-year committed dose equivalent (population dose plus occupational dose from decontamination) versus decontamination time. The population dose is considered to be the same as that calculated by the dose scenarios described in the previous section reduced as a function of the assumed decontamination factor and time. The occupational dose is found by assuming that two workers are exposed at an average distance of $1 \mathrm{~m}$ away from the spent fuel cask they are decontaminating.

Records from industry of spent fuel cask decontaminations are used as a basis for estimating decontamination methods, factors, and costs in Section 4.3 of this report. The records reviewed indicate that all casks are routinely decontaminated before any surface contamination levels are recorded. This initial decontamination takes about two hours, and subsequent decontamination of "hot" spots takes about 30 minutes each. From the data on multiple decontamination of spent fue casks (shown in Figures 4.3-1 and 4.3-2 of Chapter 4) average decontamination factors are estimated to range between 2 and 15 per 30 minutes of 


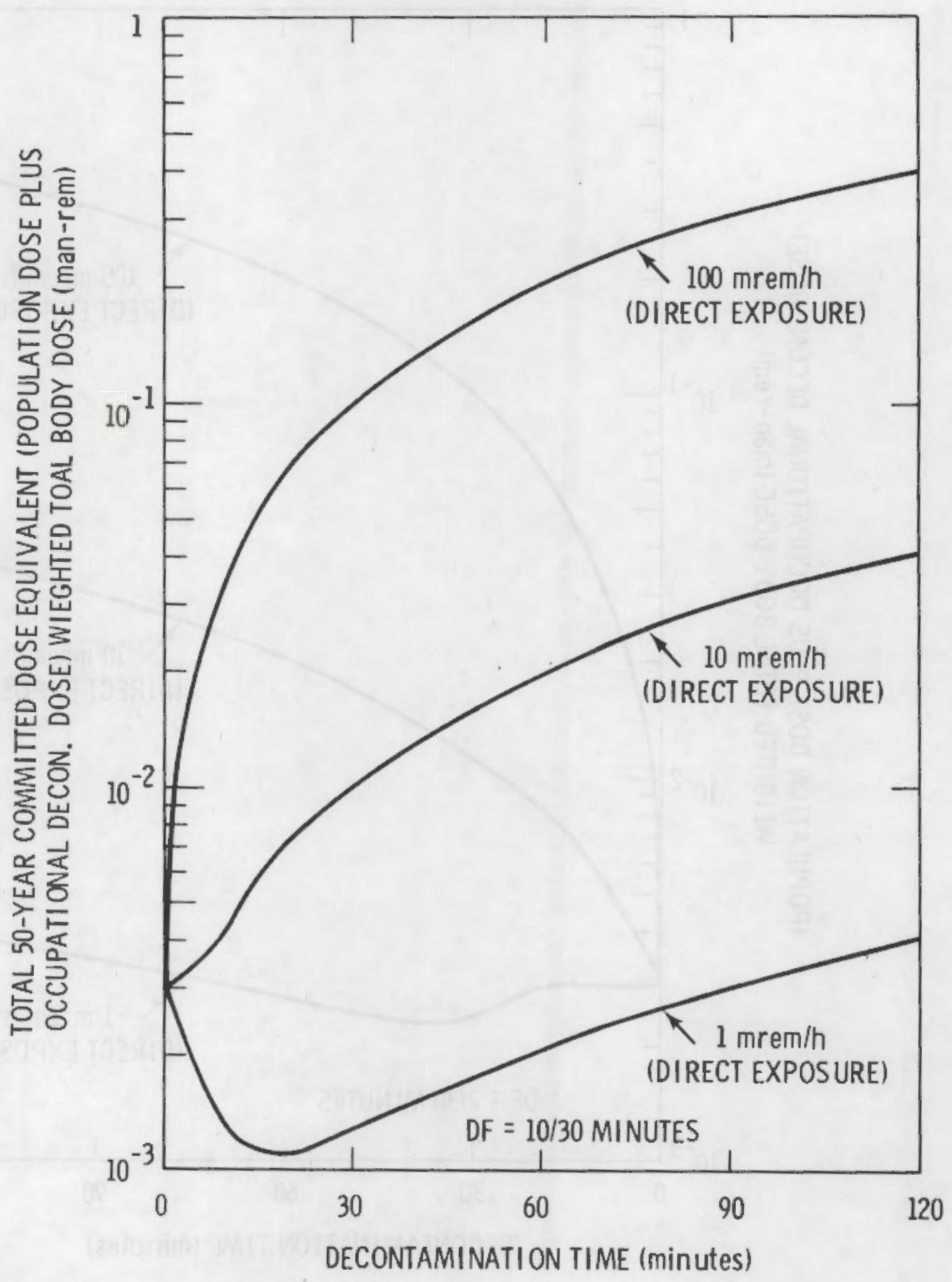

FIGURE 3.4-1 Total Dose Versus Decontamination Time for Spent Fuel Beta-Ganma Mixture - Starting at a Level of $10^{-4} \mu \mathrm{Ci} / \mathrm{cm}^{2}-\mathrm{DF}=10 / 30$ Minutes 


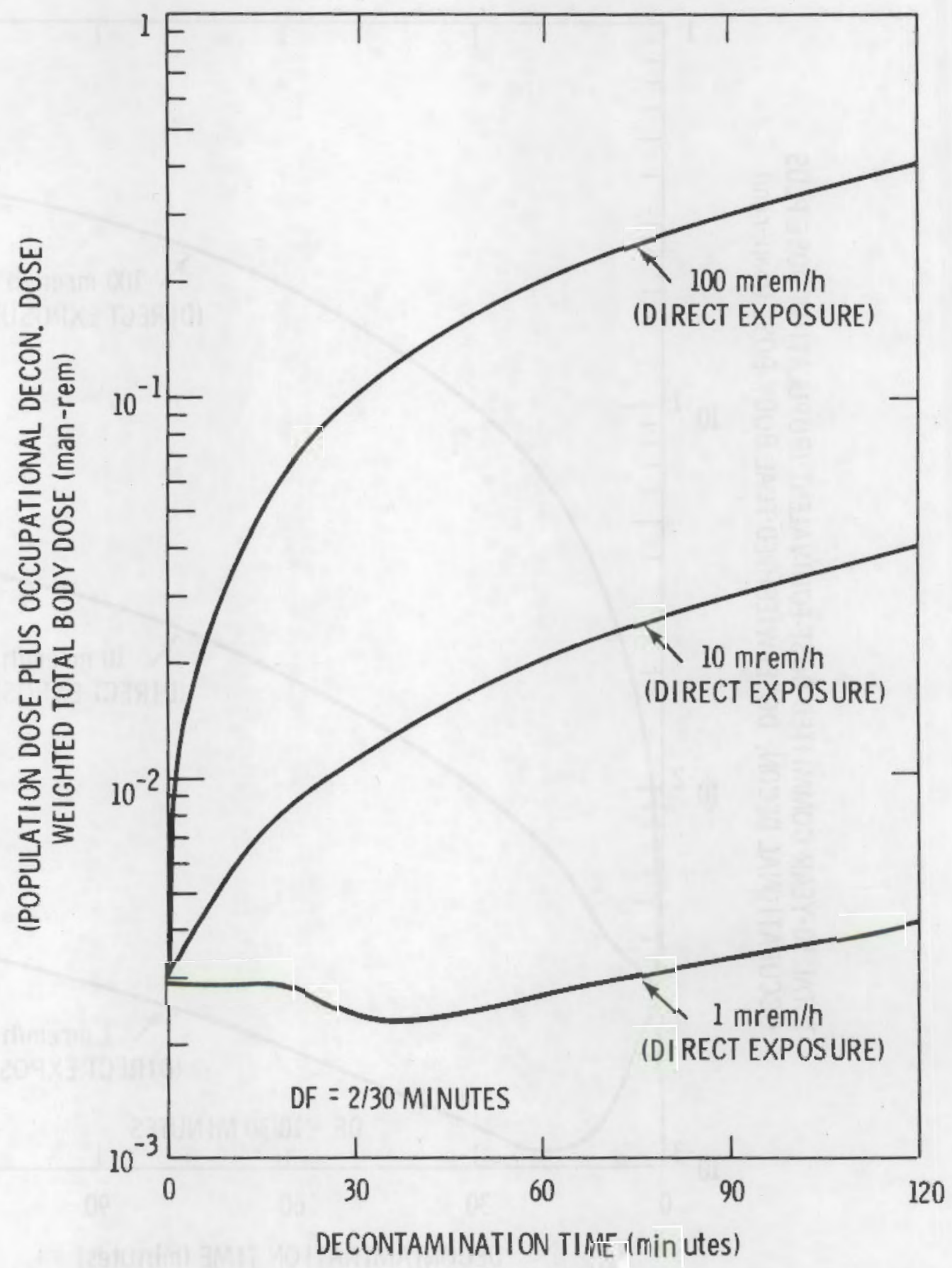

FIGURE 3.4-2 Total Dose Versus Decontamination Time for Spent Fuel Beta-Gamma Mixture - Starting at a Level of $10^{-4} \mu \mathrm{Ci} / \mathrm{cm}^{2}-D F=2 / 30$ Minutes 


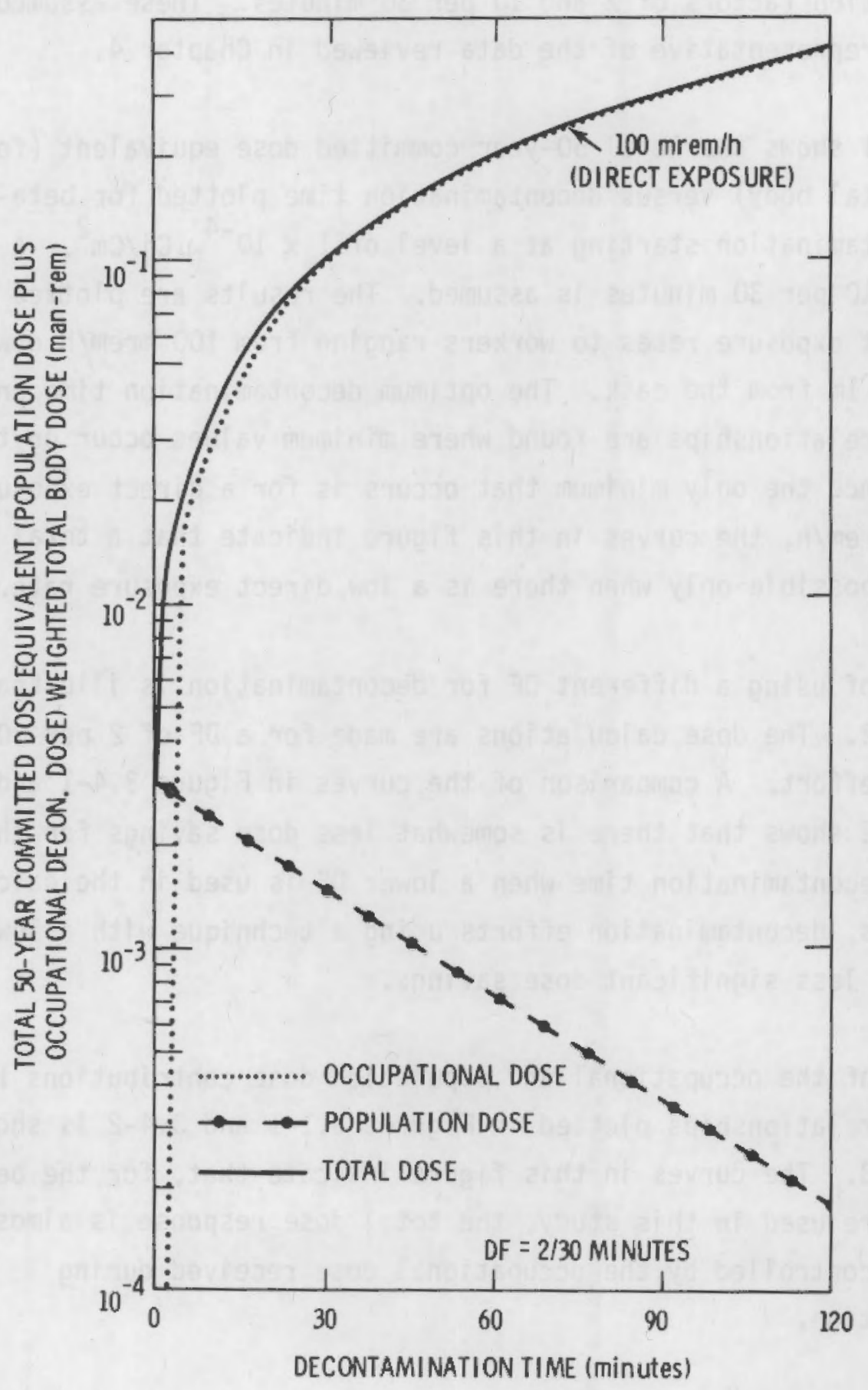

FIGURE 3.4-3 Population and Occupational Dose Comparison For Spent Fuel Cask Decontamination 
effort. The dose comparisons in this section are made by assuming decontamination factors of 2 and 10 per 30 minutes. These assumed DF values are representative of the data reviewed in Chapter 4.

Figure 3.4-1 shows the tota1 50-year committed dose equivalent (for weighted total body) versus decontamination time plotted for beta-garma surface contamination starting at a level of $1 \times 10^{-4} \mu \mathrm{Ci} / \mathrm{Cm}^{2}$. A uniform DF of 10 per 30 minutes is assumed. The results are plotted for three direct exposure rates to workers ranging from $100 \mathrm{mrem} / \mathrm{h}$ down to $1 \mathrm{mrem} / \mathrm{h}$ at $1 \mathrm{~m}$ from the cask. The optimum decontamination time and total dose relationships are found where minimum values occur on these curves. Since the only minimum that occurs is for a direct exposure rate of $1 \mathrm{mrem} / \mathrm{h}$, the curves in this figure indicate that a total dose savings is possible only when there is a low direct exposure rate.

The impact of using a different DF for decontamination is illustrated in Figure 3.4-2. The dose calculations are made for a DF of 2 per 30 minutes of effort. A comparison of the curves in Figure 3.4-1 and Figure 3.4-2 shows that there is somewhat less dose savings for the same amount of decontamination time when a lower DF is used in the calculations. Thus, decontamination efforts using a technique with a low DF result in a less significant dose savings.

An example of the occupational and population dose contributions to the total dose relationships plotted in Figures 3.1-1 and 3.4-2 is shown in Figure 3.4-3. The curves in this figure indicate that, for the betagamma mixture used in this study, the total dose response is almost completely controlled by the occupational dose received during decontamination.

\subsection{Low-Level Radioactive Waste}

Because of the many types of radioactive waste, it is first important to establish the radionuclides of concern in this study. Table 3.5-1 contains a listing of the more common radionuclides found in waste 

TABLE 3.5-1. Representative Radionyc] ides in Low-
Level Waste Shipments

\begin{tabular}{|c|c|c|c|c|c|}
\hline Radionuclide & $\begin{array}{l}\text { Physical } \\
\text { Half-Life } \\
\text { (Years) }\end{array}$ & $\begin{array}{c}(\mathrm{MPC})_{\mathrm{a}}^{(\mathrm{b})} \\
(\mathrm{Ci/m}) \\
\end{array}$ & Radionuclide & $\begin{array}{c}\text { Physical } \\
\text { Half-Life } \\
\text { (Years) }\end{array}$ & $\begin{array}{c}(M P C)_{a}^{(b)} \\
(\mathrm{Ci} / \mathrm{m})\end{array}$ \\
\hline $3_{H}$ & $1.2 \times 10^{1}$ & $2 \times 10^{-7}$ & ${ }^{135} \mathrm{Cs}$ & $3.0 \times 10^{6}$ & $3 \times 10^{-9}$ \\
\hline${ }^{14} \mathrm{C}$ & $5.7 \times 10^{3}$ & $1 \times 10^{-7}$ & ${ }^{137} \mathrm{Cs}_{\mathrm{s}}$ & $3.0 \times 10^{1}$ & $5 \times 10^{-10}$ \\
\hline${ }^{51} \mathrm{Cr}$ & $7.6 \times 10$ & $8 \times 10^{-8}$ & ${ }^{144} \mathrm{Ce}$ & $7.8 \times 10^{-1}$ & $2 \times 10^{-10}$ \\
\hline $54 M n$ & $8.3 \times 10^{-1}$ & $1 \times 10^{-9}$ & $222_{R n}(d)$ & $1.0 \times 10^{-2}$ & $3 \times 10^{-9}$ \\
\hline $55 \mathrm{Fe}$ & $2.6 \times 10^{0}$ & $3 \times 10^{-8}$ & $226_{\mathrm{Ra}}$ & $1.6 \times 10^{3}$ & $2 \times 10^{-12}$ \\
\hline${ }^{58} \mathrm{Co}$ & $2.0 \times 10^{-1}$ & $2 \times 10^{-9}$ & ${ }^{230} \mathrm{Th}$ & $8.0 \times 10^{4}$ & $8 \times 10^{-4}$ \\
\hline${ }^{60} \mathrm{Co}$ & $5.3 \times 10^{0}$ & $3 \times 10^{-10}$ & $232 \mathrm{Th}$ & $1.4 \times 10^{10}$ & $1 \times 10^{-12}$ \\
\hline${ }^{59} \mathrm{Ni}$ & $8.0 \times 10^{4}$ & $3 \times 10^{-8}$ & $235 u$ & $7.1 \times 10^{8}$ & $4 \times 10^{-12}$ \\
\hline${ }^{63} \mathrm{Ni}$ & $9.2 \times 10^{1}$ & $2 \times 10^{-9}$ & $238 v$ & $4.5 \times 10^{9}$ & $3 \times 10^{-12}$ \\
\hline $65 \mathrm{Zn}$ & $6.7 \times 10^{-1}$ & $2 \times 10^{-9}$ & $237_{N p}$ & $2.1 \times 10^{6}$ & $1 \times 10^{-13}$ \\
\hline $90 \mathrm{Sr}$ & $2.8 \times 10^{1}$ & $3 \times 10^{-11}$ & $238 p_{u}$ & $8.6 \times 10^{1}$ & $7 \times 10^{-14}$ \\
\hline $90 Y(c)$ & $7.3 \times 10^{-3}$ & $3 \times 10^{-9}$ & ${ }^{239} \mathrm{pu}$ & $2.4 \times 10^{4}$ & $6 \times 10^{-14}$ \\
\hline $95 \mathrm{Zr}$ & $1.8 \times 10^{-1}$ & $1 \times 10^{-9}$ & $240 \mathrm{pu}$ & $6.6 \times 10^{3}$ & $6 \times 10^{-14}$ \\
\hline${ }^{99} \mathrm{Tc}$ & $2.1 \times 10^{5}$ & $2 \times 10^{-9}$ & $241 p_{u}$ & $1.3 \times 10^{1}$ & $3 \times 10^{-12}$ \\
\hline${ }^{106} \mathrm{Ru}$ & $1.0 \times 10^{0}$ & $2 \times 10^{-10}$ & $242 p_{u}$ & $3.8 \times 10^{5}$ & $6 \times 10^{-14}$ \\
\hline $124 \mathrm{Sb}$ & $1.6 \times 10^{-1}$ & $7 \times 10^{-10}$ & $241_{A m}$ & $4.6 \times 10^{2}$ & $2 \times 10^{-13}$ \\
\hline $125 \mathrm{Sb}$ & $2.7 \times 10^{0}$ & $9 \times 10^{-10}$ & $243 \mathrm{Am}$ & $8.0 \times 10^{3}$ & $2 \times 10^{-13}$ \\
\hline${ }^{129} \mathrm{I}$ & $1.7 \times 10^{7}$ & $2 \times 10^{-11}$ & ${ }^{242} \mathrm{Cm}$ & $4.4 \times 10^{1}$ & $4 \times 10^{-12}$ \\
\hline${ }^{134} \mathrm{Cs}$ & $2.0 \times 10^{0}$ & $4 \times 10^{-10}$ & ${ }^{244} \mathrm{Cm}$ & $1.8 \times 10^{1}$ & $3 \times 10^{-13}$ \\
\hline
\end{tabular}

(a) Based on the radionuclides listed in Table 7.3-3 from Murphy and Holter, 1980.

(b) The (MPC) a are from Tabie II, Column 1 of 10CFR20, 1980, and are for the smallest value of either Soluble (S) or Insoluble (I) forms.

(c) Short-lived daughter of parent with same mass number.

(d) Short-lived daughter of $226 \mathrm{Ra}$. 
shipments. The physical half-life and (MPC) for each radionuclide are also 1 isted. It should be remembered that waste containers in a shipment rarely contain only one radionuclide, but rather they contain an assorted mixture of many different radionuclides. This is especially true for wastes coming from operating nuclear reactor power stations, where a complex mixture of fission products can originate.

It is difficult to determine the most hazardous radionuclides present in low-level radioactive waste shipments since many physical and chemical forms may be present. In this study we will consider three groups of radionuclides in the dose calculations: alpha, beta, and gamma-ray emitters. From the data in Table 3.5-1, the most restrictive (smallest) value of (MPC) $a$ is found for ${ }^{239} \mathrm{Pu}$ and other isotopes of plutonium. This radionuclide is used in the dose calculations for alpha emitters. The most restrictive beta emitters based on the (MPC) values listed in Table $3.5-1$ are ${ }^{129} \mathrm{I}$ and ${ }^{90} \mathrm{Sr}$. These radionuclides are used in the dose calculations to determine the most restrictive beta emitter. For common gamma emitters, ${ }^{60} C_{0}$ has the most restrictive value of (MPC) $a$, and is used in the dose calculations.

Radiation doses from surface contamination on low-level radioactive waste containers are calculated in the following sections. First, a reference low-level waste container is defined. The design of this reference container is then used to help define radiation exposure scenarios. The exposure scenarios define a composite transportation worker, individual in the public, and population group. The doses from several pathways and scenarios are combined to create these composite individuals or groups.

\subsubsection{Reference Low-Level Waste Container}

Standard containers that are commonly used to transport low-level radioactive waste are listed in Table 3.5-2. The most common types of containers encountered are: steel cask liners, plywood boxes, and standard 
TABLE 3.5-2 Standard Low-Level Radioactive Waste Shipping Containers(a)

\begin{tabular}{|c|c|c|c|}
\hline Description & Volume $\left(\mathrm{m}^{3}\right)$ & Application & Unit Cost $(\$)^{(b)}$ \\
\hline $\begin{array}{l}\text { Steel Cask Liner } \\
0.63 \mathrm{~m} 0.0 \text {. x } 1.02 \mathrm{~m} \\
\text { high, } 150 \mathrm{~kg} \text { empty }\end{array}$ & 0.33 & $\begin{array}{l}\text { Shallow-Land Burial of } \\
\text { Activated Reactor Com- } \\
\text { ponents }\end{array}$ & 450 \\
\hline $\begin{array}{l}\text { Steel Box } \\
\text { Specially Fabricated }\end{array}$ & Variable & $\begin{array}{l}\text { Shallow-Land Burial of } \\
\text { Large or Odd-Shaped } \\
\text { Activated Reactor Com- } \\
\text { ponents }\end{array}$ & 6,000 \\
\hline $\begin{array}{l}\text { Fiberglassed Plywood } \\
\text { Box, } 1.2 \mathrm{~m} \times 1.2 \mathrm{~m} \mathrm{x} \\
2.4 \mathrm{~m}, 175 \mathrm{~kg} \text { empty }\end{array}$ & 3.64 & $\begin{array}{l}\text { Low Specific Activity } \\
\text { Materials - Piping, } \\
\text { Concrete, Contaminated } \\
\text { Components }\end{array}$ & 400 \\
\hline $\begin{array}{l}\text { Fiberglassed Plywood } \\
\text { Box, Specially Fabri- } \\
\text { cated }\end{array}$ & Variable & $\begin{array}{l}\text { Low Specific Activity } \\
\text { Material, Over-Sized or } \\
\text { Extra Heavy }\end{array}$ & of surface \\
\hline $\begin{array}{l}\text { Steel Cask Liner } \\
1.38 \mathrm{~m} 0.0 \mathrm{D} \times 1.9 \mathrm{~m} \\
\text { high, } 680 \mathrm{~kg} \text { empty }\end{array}$ & 2.84 & $\begin{array}{l}\text { Solidified Wet Solid } \\
\text { Wastes }\end{array}$ & .550 \\
\hline $\begin{array}{l}\text { Standard Steel Drum } \\
0.21 \mathrm{~m}^{3}, 23 \mathrm{~kg} \text { empty }\end{array}$ & 0.21 & $\begin{array}{l}\text { Compacted Dry Solid } \\
\text { Wastes/Radio- } \\
\text { pharmaceuticals }\end{array}$ & 20 \\
\hline
\end{tabular}

steel drums. For this study, the reference low-level waste container is defined to be a standard steel drum. The volume of this drum is 0.21 $\mathrm{m}^{3}$ (55 gallons), and the estimated surface area is $2.3 \mathrm{~m}^{2}$. This reference container is selected as being representative of containers used today, and no further attempt is made to model the specific differences found in container design.

\subsubsection{Low-Level Waste Radiation Exposure Scenarios}

Radiation exposure scenarios are defined in this section for low-level waste shipments. Three exposure pathways (ingestion, inhalation, and direct exposure) are considered to define the composite transportation 
worker, individual in the public, and population group. Since the containers used for shipment of low-level radioactive waste are disposed of in the burial grounds, none are assumed to be released to the public. Total occupational dose is estimated by multiplying the individual worker dose by four, assuming that four workers are equally exposed. This is done to account for all workers who may receive less dose than the composite individual worker defined in this study. The following sections contain the radiation dose scenarios for the exposure pathways considered. A special section is included to discuss the accumulated total dose to the public and to workers during decontamination of waste drums.

\subsubsection{Direct Ingestion}

Transportation workers are assumed to ingest surface contamination from $5.0 \times 10^{-5} \mathrm{~m}^{2}$ of surface. Since none of the waste containers are released to the public and since exclusive use shipments are common, no direct ingestion by an individual in the public could occur from contact with a container surface. Secondary ingestion could occur if food products or people are in contact with a truck surface after contact with a container surface. The dose to a limited population group is calculated assuming that $2.3 \times 10^{-3} \mathrm{~m}^{2}$ of surface contamination $\left(1 \times 10^{-3}\right.$ $\mathrm{m}^{2}$ per $\mathrm{m}^{2}$ of container surface times $2.3 \mathrm{~m}^{2}$ of container surface) is ingested. A total of 10 people are assumed to be in the population group and they are assumed to ingest equal amounts of this surface contamination. The waste drums are assumed to be double stacked in the closed transport vehicle, and thus $50 \%$ of them do not have contact with truck surfaces.

\subsubsection{Inhalation}

For the resuspension of material from waste container surfaces, the local air concentrations (in $\mathrm{Ci} / \mathrm{m}^{3}$ ) are found using Equation 3.1. Where $\Omega$ equals the surface contamination level (in $\mathrm{Ci} / \mathrm{m}^{2}$ ), the resulting air concentrations are calculated to be: $\left[1.4 \times 10^{-6} \cdot \Omega\right]$ in the shipping or receiving room, and $\left[1.9 \times 10^{-6} \cdot \Omega\right]$ in the closed transport vehicle. Since the shipment of low-level waste is usually done in exclusive use 
closed transport vehicles, and since no containers are released to the public, there is no inhalation exposure to either the individual or a population group other than transport workers. There is also no incineration of empty containers, and thus no dose calculations are required. For direct inhalation, workers are the only ones that are in contact with the containers, and they are assumed to inhale the equivalent of $5 \times 10^{-5} \mathrm{~m}^{2}$ of surface contamination.

\subsubsection{Direct Exposure}

Since none of the low-level waste containers are released to the public, only transportation workers are exposed. The dose component associated with surface contamination on the outside of the reference drum is calculated assuming that each transportation worker spends 30 minutes at an average of $1 \mathrm{~m}$ from the container.

\subsubsection{Radiation Doses from Low-Level Radioactive Waste Transportation} Containers

The results of radiation dose calculations performed for the surface contamination scenarios for low-level radioactive waste transportation containers are presented in Tables 3.5-3 and 3.5-4. All of these doses are calculated based on current DOT contamination limits (i.e. $10^{-4}$ $\mu \mathrm{Ci} / \mathrm{cm}^{2}$ for beta-garma emitting radionuclides, and $10^{-5} \mu \mathrm{Ci} / \mathrm{cm}^{2}$ for all alpha emitting radionuclides except for natural or depleted uranium or thorium). The doses in Tables 3.5-3 and 3.5-4 are calculated for ingestion and inhalation doses only. A preliminary calculation for the direct exposure pathway indicated that the doses were about three orders of magnitude less than the doses from inhalation or ingestion. They have been omitted from further consideration for the low-level radioactive waste category on this basis.

Table 3.5-3 contains the calculated dose to a composite worker and an estimate of the collective occupational dose based on the assumption that this total is four times larger than the dose to the composite 


\section{TABLE 3.5-3. Individual and Collective Doses to Composite Workers from Surface Contamination - Low-Level Radioactive Waste Transportation Containers (at $10^{-5} \mu \mathrm{Ci} / \mathrm{cm}^{2} \alpha$ and $\left.10^{-4} \mu \mathrm{Ci} / \mathrm{cm}^{2} \beta-\gamma\right)$}

\begin{tabular}{|c|c|c|c|c|c|c|c|c|}
\hline \multirow[b]{2}{*}{ Redionuclide/Pathway } & \multicolumn{4}{|c|}{ Jirst-Year Dose Equivalent (rem) } & \multicolumn{4}{|c|}{$\mathrm{SO}_{f}$ (gar comitted Dose Equivalent (rew) } \\
\hline & Iothi lody & Cone & Luns & Thyroid & Total body & sone & Luns _ - & Mirrold \\
\hline \multicolumn{9}{|l|}{$239 p_{p u}$} \\
\hline $\begin{array}{l}\text { Imalate ion } \\
\text { Lomding In londing }\end{array}$ & $2.4 \times 10^{-6}$ & $3.0 \times 10^{-6}$ & $1.7 \times 10^{-5}$ & $\ldots$ (b) & $2.2 \times 10^{-5}$ & $1.4 \times 10^{-4}$ & $4.2 \times 10^{-5}$ & $\ldots(b)$ \\
\hline Closed venficle & $3.2 \times 10^{-6}$ & $4.0 \times 10-6$ & $2.3 \times 10^{-5}$ & $\cdots$ & $2.4 \times 10^{-5}$ & $1.4 \times 10^{-4}$ & $5.8 \times 10^{-5}$ & $\cdots$ \\
\hline Oirect from Kands & $4.8 \times 10^{-8}$ & $5.9 \times 10^{-8}$ & $3.4 \times 10^{-7}$ & $\ldots$ & $4.4 \times 10^{-7}$ & $2.8 \times 10^{-6}$ & $8.4 \times 10^{-7}$ & $\cdots$ \\
\hline Ingestion & $5.8 \times 10^{-9}$ & $4.8 \times 10^{-8}$ & $\cdots$ & $\cdots$ & $2.4 \times 10^{-7}$ & $2.0 \times 10^{-6}$ & $\cdots$ & -- \\
\hline $\begin{array}{l}\text { Total Caposite } \\
\text { Worker }\end{array}$ & $5.6 \times 10^{-6}$ & $7.1 \times 10^{-6}$ & $4.0 \times 10^{-5}$ & $\cdots$ & $4.7 \times 10^{-5}$ & $2.8 \times 10^{-4}$ & $1.0 \times 10^{-4}$ & ... \\
\hline $\begin{array}{l}\text { Total accupational(c) } \\
\text { (an-ren) }\end{array}$ & $2.3 \times 10.5$ & $2.8 \times 10^{-5}$ & $1.6 \times 10^{-4}$ & -. & $1.9 \times 10^{-4}$ & $1.1 \times 10^{-3}$ & $4.0 \times 10^{-4}$ & $\cdots$ \\
\hline \multicolumn{9}{|l|}{$129 !$} \\
\hline $\begin{array}{l}\text { Imalation } \\
\text { Lodeding/Unloading }\end{array}$ & $1.4 \times 10^{-7}$ & $1.6 \times 10^{-10}$ & $6.2 \times 10^{-10}$ & $4.5 \times 10^{-6}$ & $1.6 \times 10^{-7}$ & $1.6 \times 10^{-9}$ & $6.2 \times 10^{-10}$ & $5.5 \times 10^{-6}$ \\
\hline Closed renicle & $1.8 \times 10^{-7}$ & $2.2 \times 10-10$ & $8.5 \times 10^{-10}$ & $6.1 \times 10^{-6}$ & $2.2 \times 10^{-7}$ & $2.2 \times 10^{-10}$ & $8.5 \times 10^{-10}$ & $7.5 \times 10^{-6}$ \\
\hline Direct from Hands & $2.7 \times 10^{-9}$ & $3.2 \times 10^{-10}$ & $1.2 \times 10.11$ & $9.0 \times 10^{-8}$ & $3.3 \times 10^{-9}$ & $3.2 \times 10^{-12}$ & $1.2 \times 10^{-11}$ & $1.1 \times 10^{-7}$ \\
\hline Ingest ion & $1.0 \times 10^{-5}$ & $1.6 \times 10^{-4}$ & $\ldots$ & $3.4 \times 10^{-4}$ & $1.1 \times 10^{-5}$ & $1.6 \times 10^{-7}$ & $\cdots$ & $3.6 \times 10^{-4}$ \\
\hline $\begin{array}{l}\text { Total Caepesite } \\
\text { Worker }\end{array}$ & $1.0 \times 10^{-5}$ & $1.6 \times 10^{-7}$ & $1.5 \times 10-9$ & $3.5 \times 10^{-4}$ & $1.1 \times 10^{-5}$ & $1.6 \times 10^{-9}$ & $1.5 \times 10^{-9}$ & $3.7 \times 10^{-4}$ \\
\hline $\begin{array}{l}\text { Total decupationolic) } \\
\text { (man-rea) }\end{array}$ & $4.1 \times 10^{-5}$ & $8.6 \times 10^{-7}$ & $5.9 \times 10^{-9}$ & $1.4 \times 10^{-3}$ & $4.5 \times 10^{-5}$ & $6.6 \times 10^{-7}$ & $5.9 \times 10^{-9}$ & $1.5 \times 10^{-3}$ \\
\hline \multicolumn{9}{|l|}{50 Sr-90Y } \\
\hline $\begin{array}{l}\text { Inhalation } \\
\text { Load ing/Unloading }\end{array}$ & $3.0 \times 10^{-7}$ & $4.8 \times 10^{-7}$ & $2.0 \times 10^{-6}$ & $\cdots$ & $1.9 \times 10^{-6}$ & $1.1 \times 10^{-5}$ & $4.8 \times 10^{-6}$ & $\cdots$ \\
\hline Closed Venicle & $4.0 \times 10^{-7}$ & $6.5 \times 10^{-7}$ & $2.7 \times 10^{-6}$ & $\cdots$ & $9.6 \times 10^{-7}$ & $1.5 \times 10^{-5}$ & $6.5 \times 10^{-6}$ & $\cdots$ \\
\hline Direct from kands & $5.9 \times 10^{-9}$ & $9.5 \times 10^{-9}$ & $4.0 \times 10^{-8}$ & $\cdots$ & $3.8 \times 10^{-8}$ & $2.2 \times 10^{-7}$ & $9.5 \times 10^{-8}$ & $\cdots$ \\
\hline Ingest ion & $2.0 \times 10^{-6}$ & $1.7 \times 10^{-5}$ & $\cdots$ & $\cdots$ & $2.3 \times 10^{-5}$ & $1.9 \times 10^{-4}$ & --- & $\cdots$ \\
\hline $\begin{array}{l}\text { Total Camposite } \\
\text { Worker }\end{array}$ & $2.7 \times 10^{-6}$ & $1.8 \times 10^{-5}$ & $4.7 \times 10^{-6}$ & $\cdots$ & $2.6 \times 10^{-5}$ & $2.2 \times 10^{-4}$ & $1.1 \times 10^{-5}$ & \\
\hline $\begin{array}{l}\text { Total Occupational(c) } \\
\text { (men-ren) }\end{array}$ & $1.1 \times 10^{-5}$ & $7.0 \times 10^{-5}$ & $1.9 \times 10^{-5}$ & -- & $1.0 \times 20^{-4}$ & $8.6 \times 10^{-4}$ & $4.5 \times 10^{-5}$ & \\
\hline \multicolumn{9}{|l|}{${ }^{60} \mathrm{CO}_{\mathrm{O}}$} \\
\hline \multicolumn{9}{|l|}{ Intulation } \\
\hline Looding/un looding & $1.4 \times 10^{-7}$ & $\cdots$ & $1.2 \times 10^{-6}$ & $\cdots$ & $3.1 \times 10^{-7}$ & $\cdots$ & $2.6 \times 10^{-6}$ & $\cdots$ \\
\hline Closed Vehicle & $2.0 \times 10^{-7}$ & $\cdots$ & $1.7 \times 10^{-6}$ & $\cdots$ & $4.2 \times 10^{-7}$ & $\cdots$ & $3.5 \times 10^{-6}$ & $\cdots$ \\
\hline Direct from Hands & $2.9 \times 10^{-9}$ & $\cdots$ & $2.4 \times 10^{-8}$ & $\cdots$ & $6.2 \times 10^{-9}$ & $\cdots$ & $5.2 \times 10^{-8}$ & $\cdots$ \\
\hline Ingest ion & $5.2 \times 10^{-7}$ & $\cdots$ & $\cdots$ & $\cdots$ & $5.2 \times 10^{-7}$ & $\cdots$ & $\cdots$ & $\cdots$ \\
\hline $\begin{array}{l}\text { Total Casposite } \\
\text { Morker }\end{array}$ & $8.6 \times 10^{-7}$ & $\cdots$ & $2.9 \times 10^{-6}$ & $\cdots$ & $1.2 \times 10^{-6}$ & -- & $6.2 \times 10^{-6}$ & ... \\
\hline $\begin{array}{l}\text { Total occupat ional(b) } \\
\text { (nen-ron) }\end{array}$ & $3.4 \times 10^{-6}$ & ... & $1.2 \times 10^{-5}$ & -- & $5.0 \times 10^{-6}$ & $\cdots$ & $2.5 \times 10^{-5}$ & $\ldots$ \\
\hline
\end{tabular}

(a) Weighted total body doses are found by suming (over the reference organs) the products of the organ-specific doses and the wighting factors discussed in ICRP 26 (1977). The wighting factors used are 0.12 for bone, 0.12 for lung, and 0.03 for thyroid. (b) A dash indicates that no organ data was available for this redionuclide.

(c) Based on the assumption that the total occupational dose is four times larger than the composite worker's base. 


\section{TABLE 3.5-4. Collective Dose to the Composite Population Group from Surface Contaminatjon - Low-Level Radioactive Waste Transportation Containers (a) (at $10^{-5} \mu \mathrm{Ci} / \mathrm{cm}^{2} \alpha$ and $10^{-4} \mathrm{Ci} / \mathrm{cm}^{2} \quad \beta-\gamma$ )}

Fjrst-Year Dose Equivalent (man-rem)

$\begin{array}{ll} & \frac{\text { Radionuclide }}{239 p_{\mathrm{u}}} \\ & 129 \mathrm{I} \\ \omega & 90 \mathrm{Sr}-90 \mathrm{Y} \\ \text { in } & 60 \mathrm{Co}\end{array}$

\section{Weighted
Total Body Bone Lung}

$\begin{array}{ll}1.4 \times 10^{-7} & 1.2 \times 10^{-6} \\ 2.4 \times 10^{-4} & 4.0 \times 10^{-6} \\ 4.8 \times 10^{-5} & 4.0 \times 10^{-4} \\ 5.4 \times 10^{-5} & \cdots\end{array}$

50-Year Committed Dose Equivalent (man-rem) Weighted gof Bone Lung Thyroid

\begin{tabular}{|c|c|}
\hline Lung & Thyroid \\
\hline$\ldots$ (c) & $\cdots$ \\
\hline -.. & $8.0 \times 10^{-3}$ \\
\hline -.. & --- \\
\hline.-- & $\cdots$ \\
\hline
\end{tabular}

$6.0 \times 10^{-6} \quad 5.0 \times 10^{-5}$

$2.6 \times 10^{-4}$

$5.5 \times 10^{-4}$

$5.4 \times 10^{-6}$

(a) The population group consists of 10 people who ingest a total of $2.3 \times 10^{-3} \mathrm{~m}^{2}$ of surface contamination that is transferred to truck surfaces. Note: only 50\% of the waste containers are in contact with the truck since they are assumed to be double stacked.

(b) Weighted total body doses are found by summing (over the reference organs) the products of the organ-specific doses and the weighting factors discussed in ICRP $26(1977)$. The weighting factors used are 0.12 for bone, 0.12 for lung, and 0.03 for thyroid.

(c) A dash indicates that no organ data was available for this radionuclide. 
worker. This assumption is made based on current information from industry, and it is assumed to account for a greater number of workers who receive less dose than the composite worker.

Since none of the transportation containers are released after their use and since exclusive use shipments are common, no public exposure pathways that involve direct contact with the containers exist. Thus, the dose to a composite individual in the public is not calculated, but rather the dose to a limited population group is calculated and listed in Table 3.5-4. The people in this population group are assumed to ingest a fraction of the surface contamination from each container that remains on truck surfaces. The doses obtained by this anlys is may be conservatively large, but they should provide a bas is for comparison with the other doses calculated in this study.

\subsubsection{Low-Level Radioactive Waste Container Decontamination}

The impact on total collective radiation dose (in man-rem) from decontamination of low-level radioactive waste containers is discussed in this section. Several factors influence the analys is of decontamination radiation exposures including the exposure rate to workers from the waste container contents, the radionuclides considered in the surface contamination dose calculations, the surface contamination level at the start of decontamination, and the decontamination factor associated with the technique used. The relative impacts of these factors are shown in Figures 3.5-1 through 3.5-3, and are discussed in the following paragraphs. All of these figures contain graphs of the total 50-year committed dose equivalent (population dose plus occupational dose from decontamination) versus decontamination time. The collective population dose is considered to be the same as that calculated in the previous section, and it is reduced as a function of decontamination factor and time. The occupational dose is found assuming that two workers are exposed at an average distance of $1 \mathrm{~m}$ away from the container that they are decontaminating. In practice, several waste drums are decontaminated at the same time prior to shipment as discussed in Section 4.3.3 of Chapter 4. 


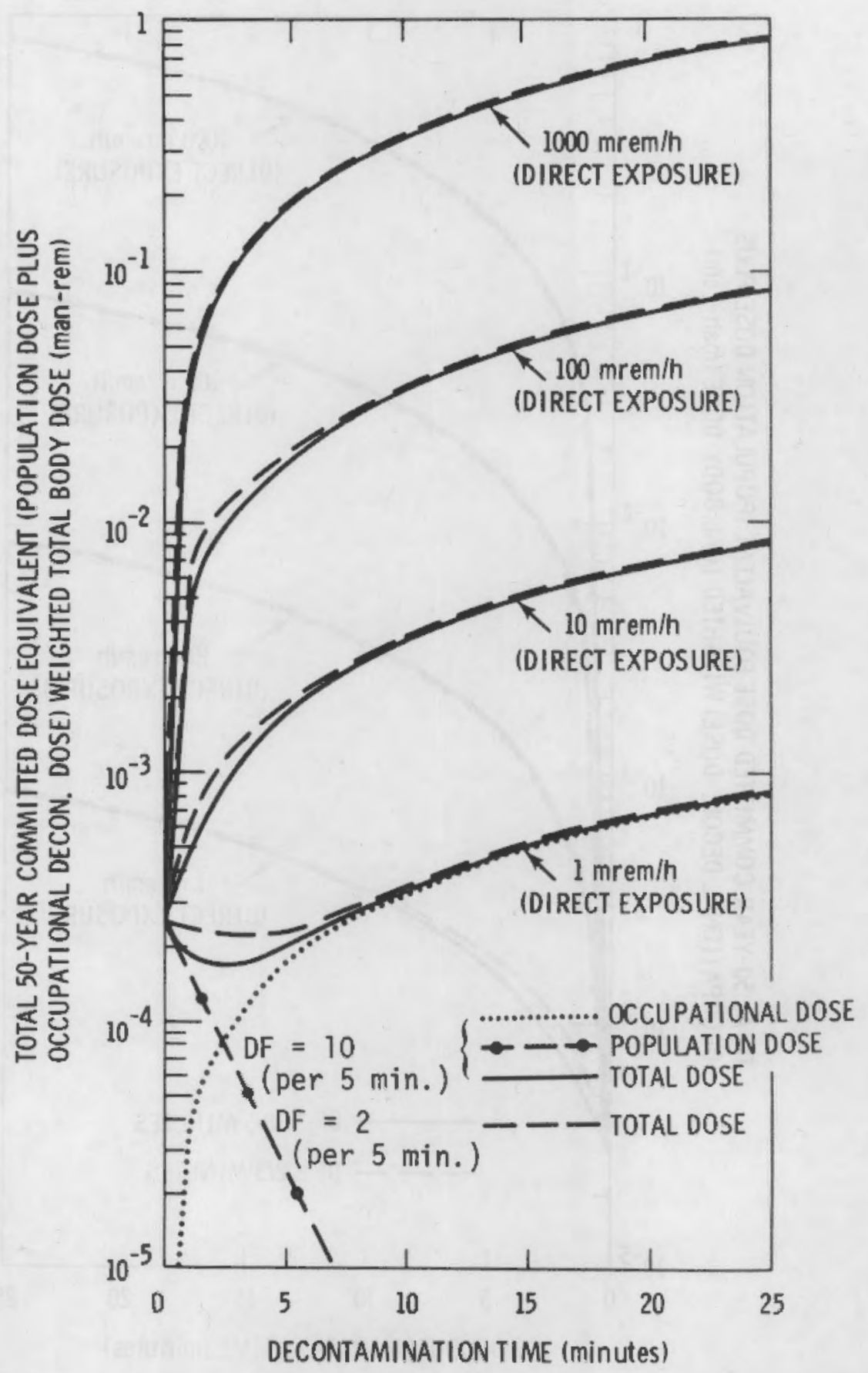

FIGURE 3.5-1 Total Dose Versus Decontamination Time for ${ }^{129}$ I Starting at a Level of $10^{-4} \mu \mathrm{Ci} / \mathrm{cm}^{2}$ 


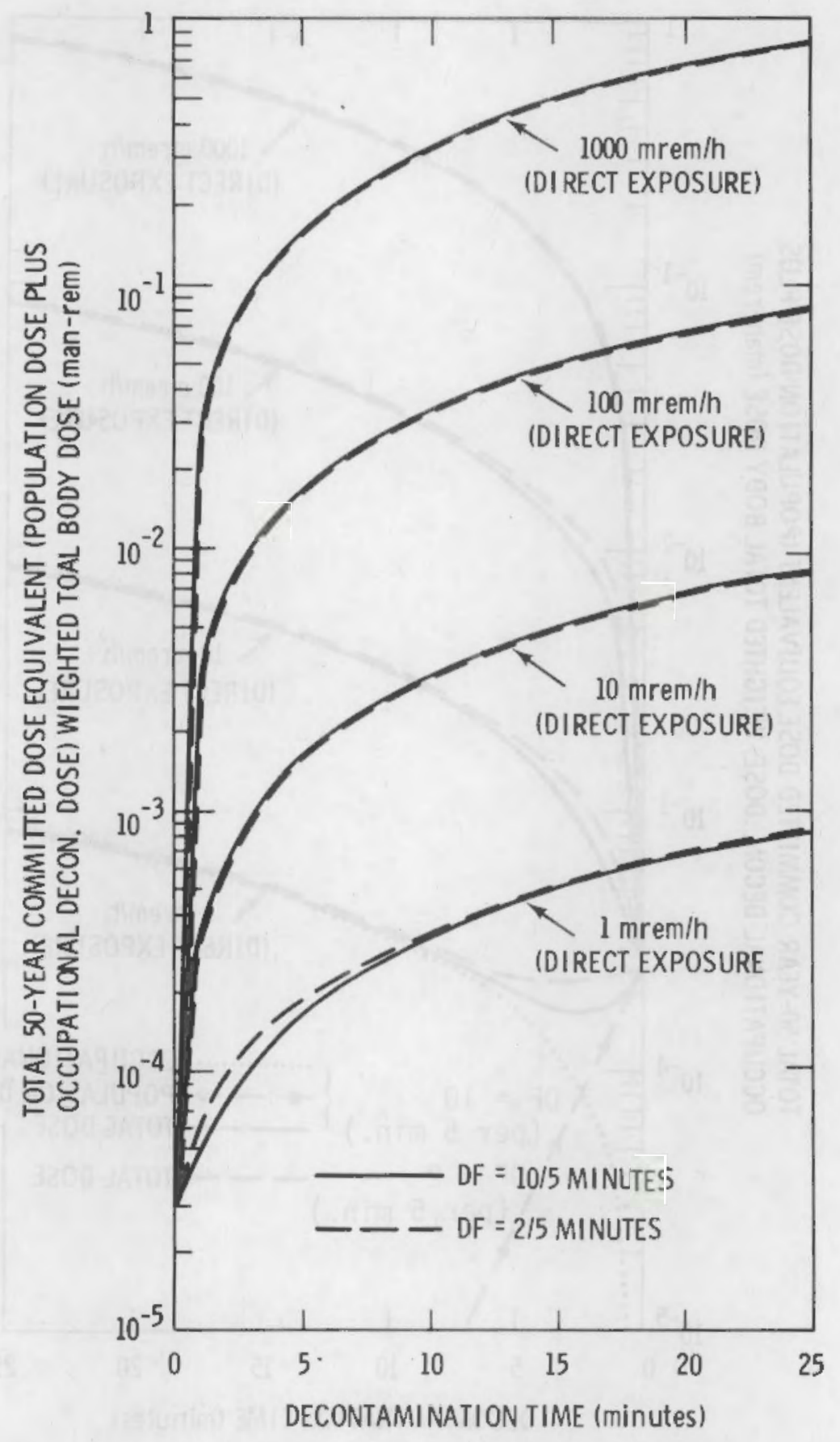

FIGURE 3.5-2 Total Dose Versus Decontamination Time for Low-Level Waste Drums - 129 I Starting at a Level of $10^{-5} \mu \mathrm{Ci} / \mathrm{cm}^{2}$ 


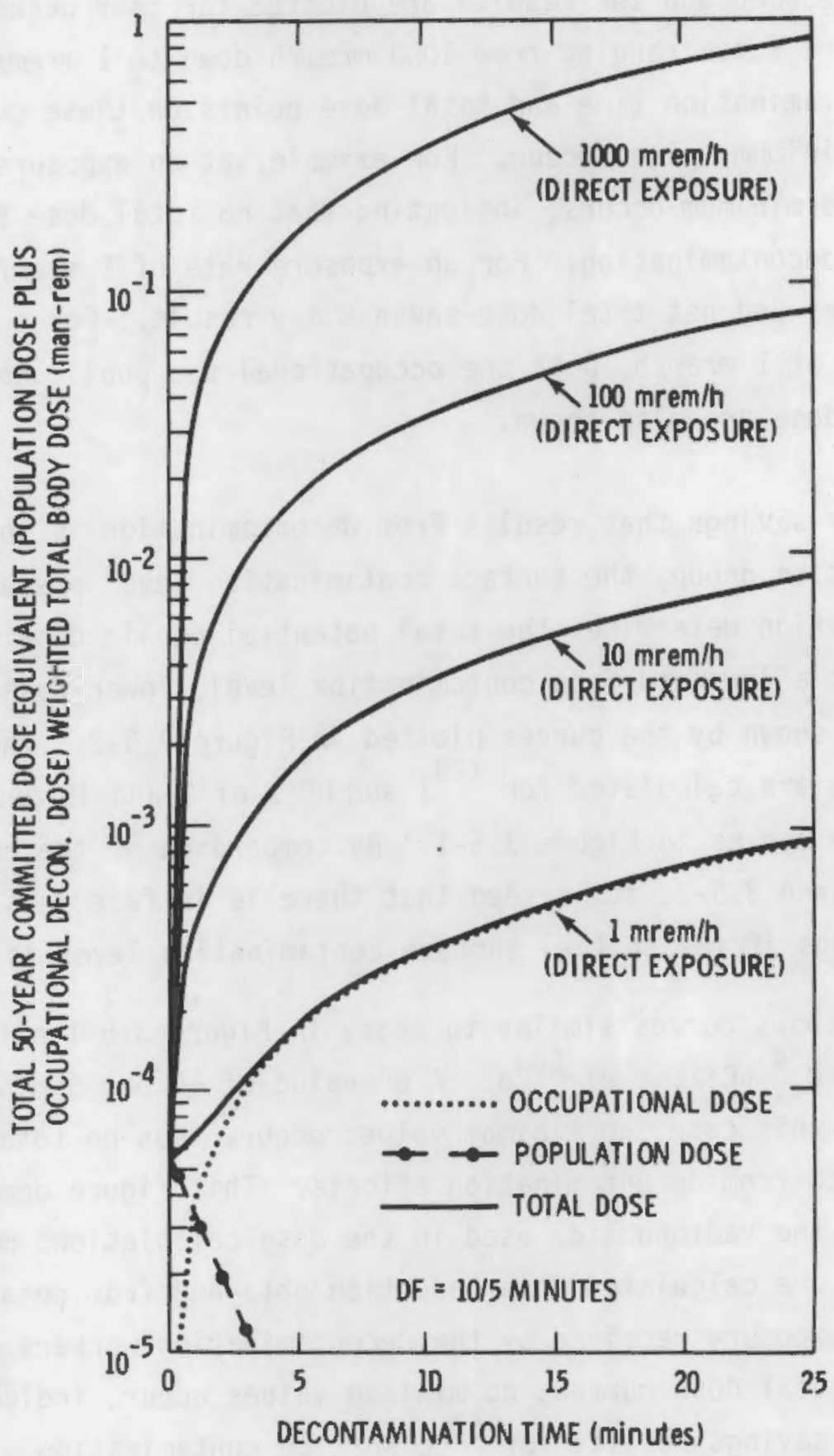

FIGURE 3.5-3 Total Dose Versus Decontamination Time for Low-Leve 7 Waste Drums $-60 \mathrm{Co}$ Starting at a Level of $10^{-4} \mu \mathrm{Ci} / \mathrm{cm}^{2}$ 
Figure 3.5-1 shows the total dose versus decontamination time plotted for ${ }^{129}$ I surface contamination at a starting level of $1 \times 10^{-4} \mu \mathrm{Ci} / \mathrm{Cm}^{2}$. Uniform decontamination factors (DF's) of 10 per 5 minutes and 2 per 5 minutes are assumed and the results are plotted for four occupational direct exposure rates ranging from $1000 \mathrm{mrem} / \mathrm{h}$ down to $1 \mathrm{mrem} / \mathrm{h}$. The optimum decontamination time and total dose points on these curves are found where minimum values occur. For example, at an exposure rate of $1000 \mathrm{mrem} / \mathrm{h}$ no minimum occurs, indicating that no total dose savings results from decontamination. For an exposure rate of $1 \mathrm{mrem} / \mathrm{h}$ a $\mathrm{mini}$ mum does occur, and net total dose savings may result. For a direct exposure rate of $1 \mathrm{mrem} / \mathrm{h}$, both the occupational and public components to the total dose are also shown.

Since the dose savings that results from decontamination is to the composite population group, the surface contamination level present prior to decontamination determines the total potential public dose savings. By starting at a lower surface contamination level, lower dose savings may result as shown by the curves plotted in Figure 3.5-2. The curves in this figure are calculated for ${ }^{129}{ }_{1}$ and $D F ' s$ of 2 and 10 per 5 minutes, similar to the curves in Figure 3.5-1. By comparison of the curves in Figures 3.5-1 and 3.5-2, it is seen that there is in fact less potential for dose savings if the initial surface contamination level is lower.

Figure 3.5-3 shows curves similar to those in Figure $3.5-1$ calculated based on $1 \times 10^{-4} \mu \mathrm{Ci} / \mathrm{cm}^{2}$ of ${ }^{60} \mathrm{Co}$. A DF value of 10 per 5 minutes is assumed. For this case, no minimum values occur, thus no total dose savings results from decontamination efforts. This figure demonstrates the fact that the radionuclide used in the dose calculations makes a difference in the calculated dose reduction obtained from decontamination. Since direct exposure received by the decontamination workers controls the shape of the total dose curves, no minimum values occur, indicating that no total dose savings results for ${ }^{60}$ Co surface contamination. 
As the curves in Figures 3.5-1 through 3.5-3 demonstrate, the dose response associated with decontamintion of low-level radioactive waste drums is a complex function of several important factors. It is therefore difficult to present a meaningful discussion that represents the current status of the decontamination techniques in use today. The data presented and discussed in this section does appear to demonstrate the nature of the factors that need to be considered, however.

\subsection{Radiation Dose Evaluation Summary}

The calculated radiation dose relationships for each of the radioactive materials categories are graphically summarized in Figures 3.6-1 through 3.6-5. The weighted total body collective 50-year committed dose equivalents (in man-rem) are shown in these figures to both workers and members of the public. The doses are shown over a range of several orders of magnitude of surface contamination level (in $\mu \mathrm{Ci} / \mathrm{Cm}^{2}$ ) so that an analys is of specific changes in limits can be made.

For radiopharmaceuticals, the doses to workers and members of the public are shown in Figure 3.6-1. Dose relationships are shown for both ${ }^{125} I$ and ${ }^{99 m_{T}} \mathrm{Tc}$ to illustrate the radionuclide dependence of the dose calculations. The weighted total body dose from ${ }^{125} \mathrm{I}$ is about 3.5 orders of magnitude larger than the dose from ${ }^{99 m}$ T.

The calculated dose relationships for industrial source materials transportation containers are shown in Figure 3.6-2. The dose relationships for ${ }^{241} \mathrm{Am},{ }^{90} \mathrm{Sr},{ }^{60} \mathrm{Co}$ and ${ }^{63} \mathrm{Ni}$ are shown. Two beta emitters $\left({ }^{90} \mathrm{Sr}\right.$ and ${ }^{63} \mathrm{Ni}$ ) are considered to show a range of doses depending upon radiotoxicity. Here the doses vary over three to four orders of magnitude depending upon the radionuclide considered in the dose calculations.

Figures 3.6-3 and 3.6-4 show the calculated dose relationships for various nuclear fuel cycle material transportation containers. Two basic types of containers for nuclear fuel cycle materials are considered: first, containers that are used to transport natural or enriched uranium, and second, spent fuel casks. Figure 3.6-3 shows both collective 


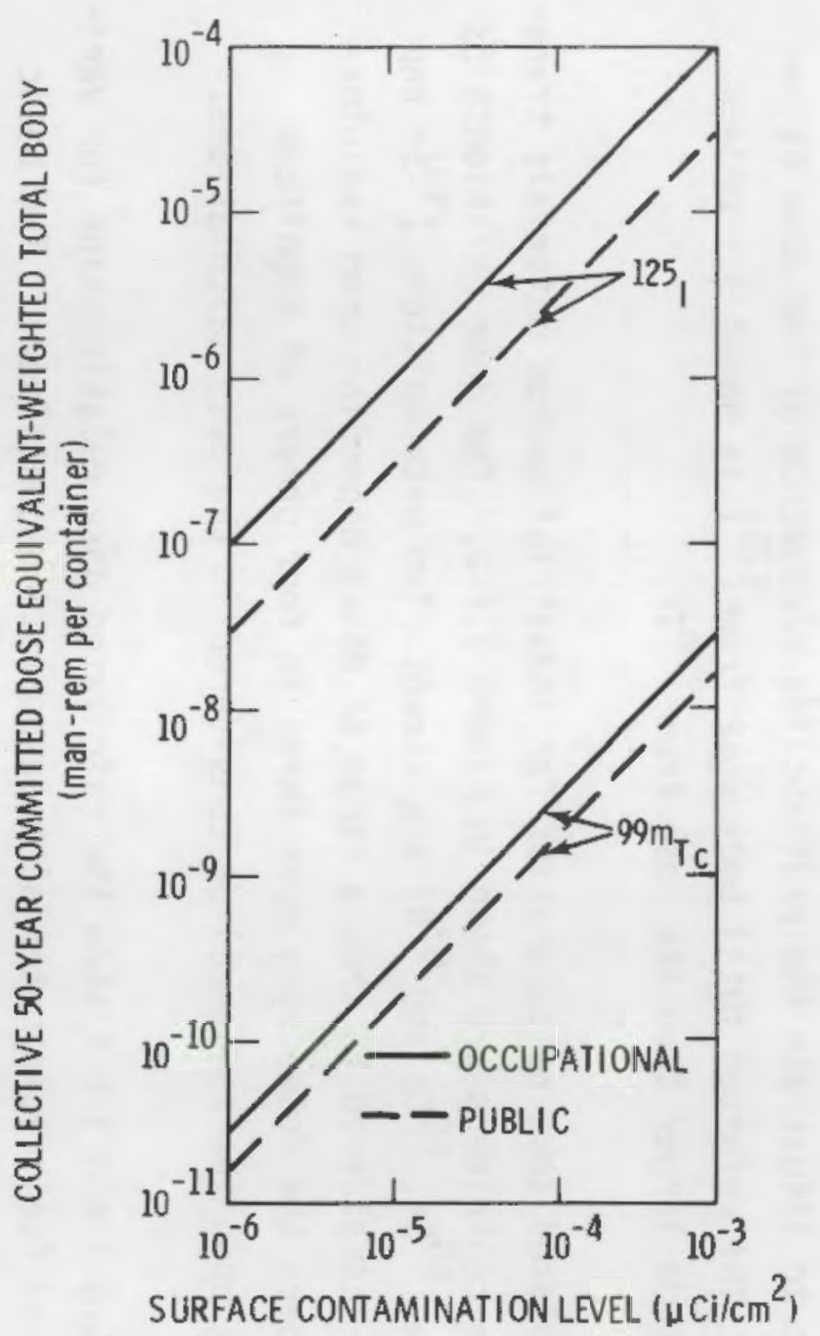

FIGURE 3.6-1 Collective Doses from Surface Contamination on Radiopharmaceutical Transportation Containers

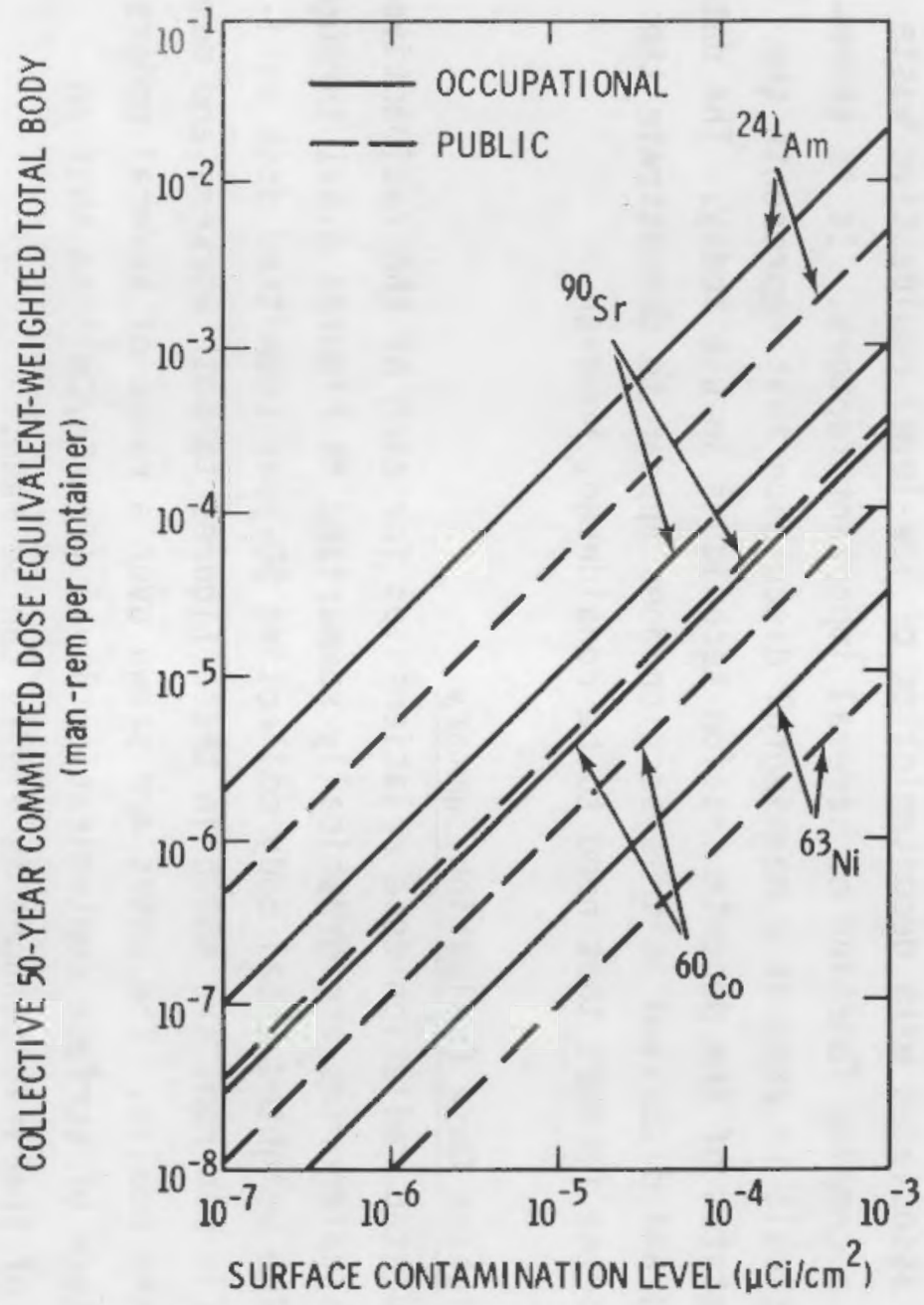

FIGURE 3.6-2 Collective Doses from Surface Contamination on Industrial Source Materials Transportation Containers 


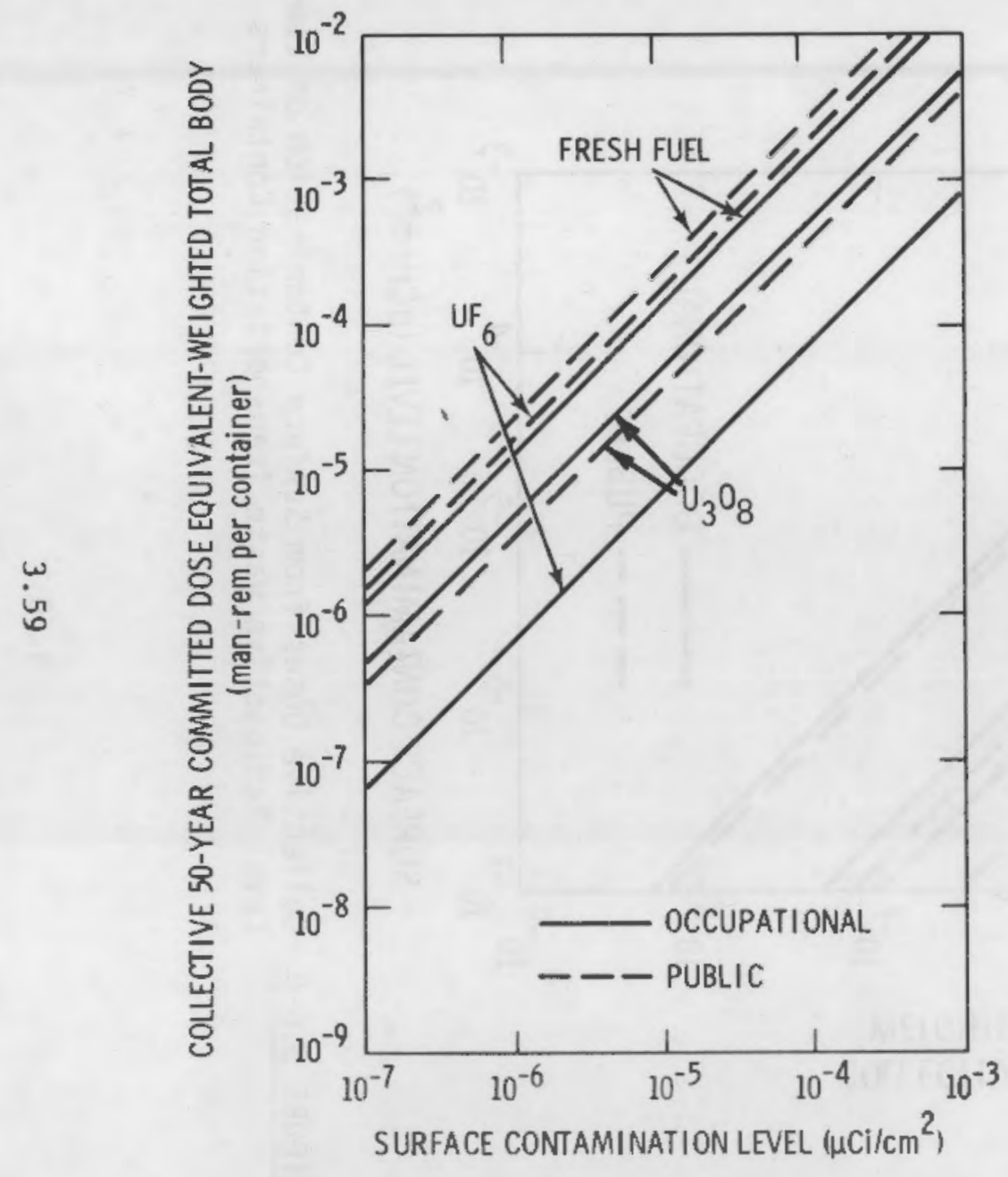

FIGURE 3.6-3 Collective Doses from Surface Contamination on Nuclear Fuel Cycle Transportation Containers

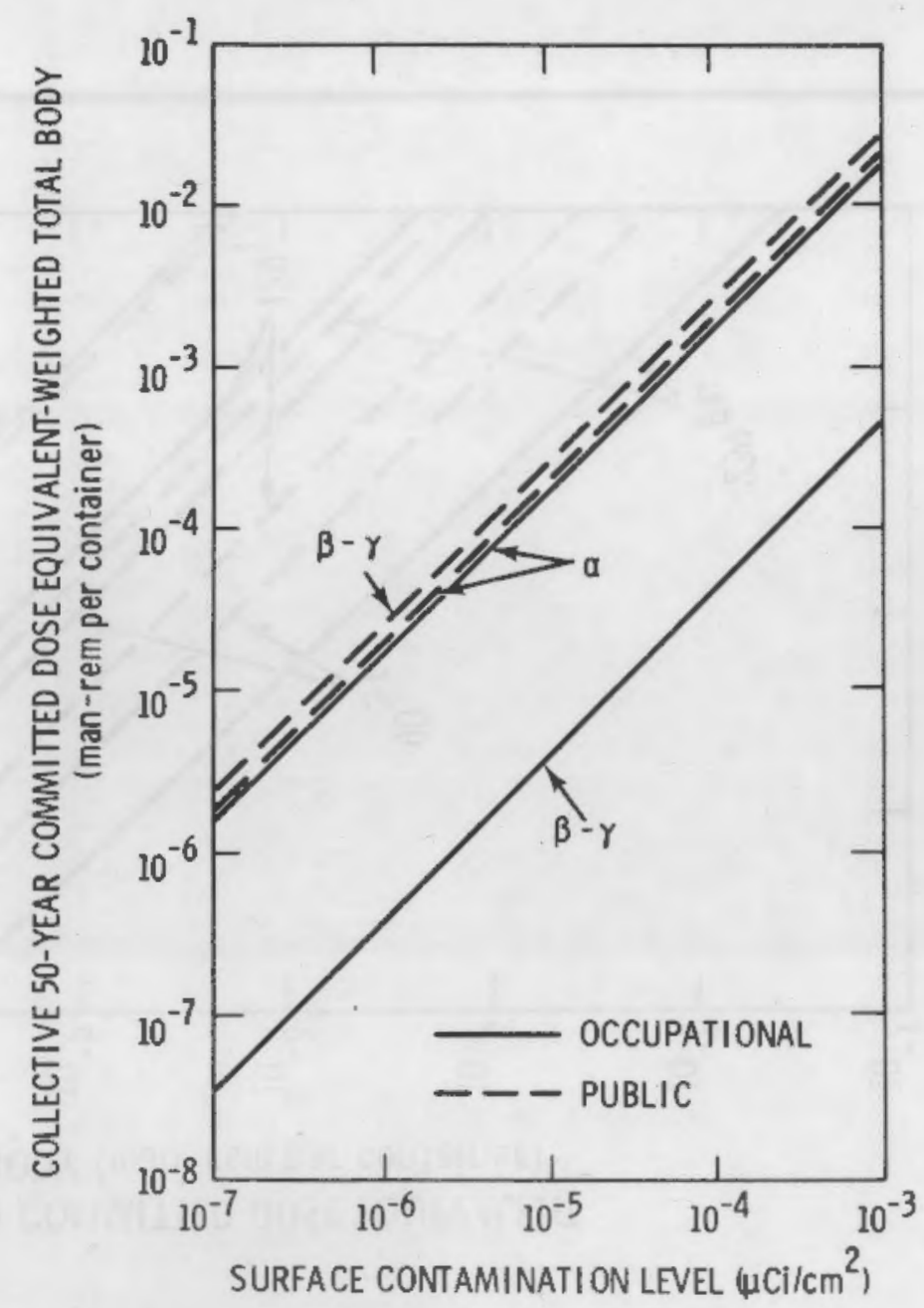

FIGURE 3.6-4 Collective Doses from Surface Contamination on Spent Fuel Transportation Containers 


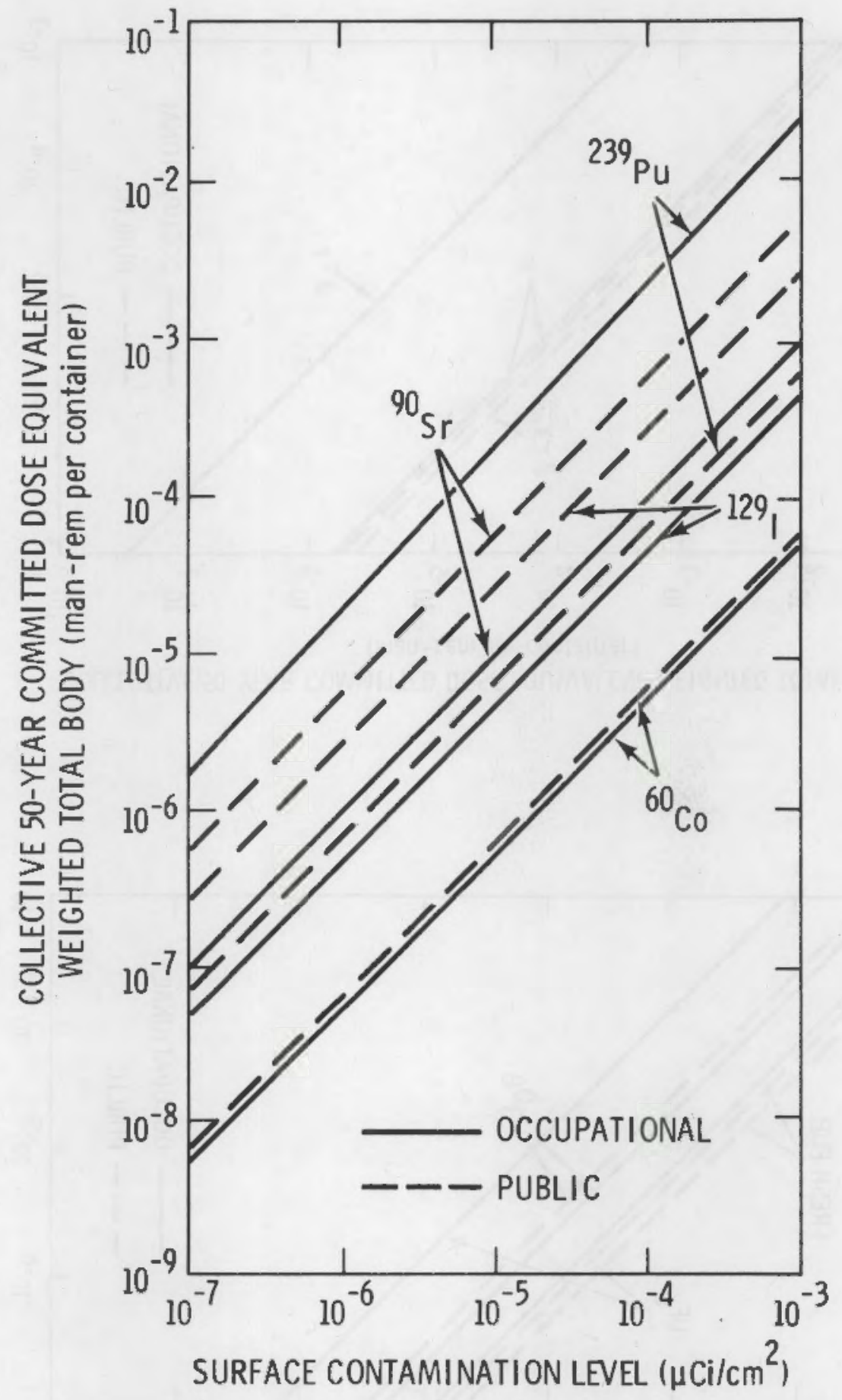

FIGURE 3.6-5 Collective Doses from Surface Contamination on LowLevel Radioactive Waste Transportation Containers 
occupational and collective public doses for $\mathrm{U}_{3} \mathrm{O}_{8}, \mathrm{UF}_{6}$ (natural or enriched), and fresh fuel containers. The differences in these doses are due to the different surface areas of the reference containers defined for each material, and how these areas are used in the dose scenarios. For spent fuel shipments, the calculated doses are based on defined reference mixtures of beta-gamma and alpha emitters. The pathway dependence of the dose calculations can be seen in Figure 3.6-4 by the difference in the behavior of collective public doses between betagamma and alpha emitters. For beta-gamma radionuclides, the dominate exposure pathway is ingestion, which results in large public doses compared to occupational doses. For alpha radionuclides, inhalation is the dominant pathway, and since only ingestion by the public is considered, the public doses are not much larger than the occupational doses.

For low-level radioactive waste shipments, the calculated dose relationships are shown in figure 3.6-5. The dose relationships for ${ }^{239} \mathrm{Pu},{ }^{90} \mathrm{Sr}$, ${ }^{129} \mathrm{I}$, and ${ }^{60} \mathrm{CO}$ are shown to demonstrate a range of radionuclidedependent doses. For comparison, the doses from ${ }^{90} \mathrm{Sr}$ and ${ }^{129} \mathrm{I}$ are calculated. The weighted total body occupational and public doses for ${ }^{90} \mathrm{Sr}$ are both larger than the corresponding doses from ${ }^{129} \mathrm{I}$. 


\section{REFERENCES}

Anspaugh, L. R. et. al. 1974. "Experimental Studies on the Resuspension of Plutonium from Aged Sources at the Nevada Test Site." AtmoSphere-Suface Exchanges of Particulate and Gaseous Pollutants, pp. 727-732, CONF-740921.

Bailey, J. C. and R. C. Rohr. 1953. The Inhalation of Radioactive Materials as Related to Hand Contamination. Report K-1-71. Dak Ridge, TN.

Colton, J. D., and R. E. Emerson. 1979. Study of the Mechanics of a Transportation Accident Involving Natural Uranium Concentrate. NUREG/CR-D558, Poulter Laboratory, SRI Internationa T, MenTo Park, CA. *

Dunster, H. J. 1962. Maximum Permissible Levels of Skin Contamination. AHSB (RP)R 28, United Kingdom Atomic Energy Authority, Authority Health and Safety Branch Report, Harwel1, Didcot, Berkshire.

Enge 1, R. L., J. Greenborg, and M. M. Hendrickson. 1966. ISDSHLD - A Computer Code for General Purpose I sotope Shielding Analys is. BNWL-236, Pac if ic Northwest Laboratory, Richland, WA.

Gibson, J. A. 8., and A. D. Wrixon. 1979. "Methods for the Calculation of Derived Working Limits for Surface Contamination by Low-Toxicity Radionuclides." Health Physics 36(3): 311-321.

Gifford, F. A. Jr., 1961. "Use of Routine Meteorological Observations for Est imating Atmospheric Dispersion." Nuclear Safety 2(4):48.

Healy, J. W., J. J. Fuquay, 1959. "Wind Pickup of Radioactive Particles from the Ground, "Progress in Nuclear Energy, series XII, Health Physics Vol. I, Pergamon Press, pp. 433-436.

Healy, J. W., 1971. Surface Contamination: Dec is ion Levels. LA-4558-MS, Los Alamos Scientific Laboratory, Los Alamos, New Mexico.

Houston, J. R., D. L. Strenge and E. C. Watson. 1976. DACRIN - A Computer Program for Calculating Organ Doses frm Acute or Chronic Radionuclide Inhatation. BNWL-B-389, Pacific Northwest Laboratory, Richland, WA.

Internationa? Commission on Radiological Protection (ICRP). 1959. Recommendations of the International Commission on Radiological Protection. ICRP Publication 2, Pergamon Press, NY.

International Commission on Radiological Protection (ICRP). 1966. Recommendations of the International Commission on Radiological ProtecEion. ICRP Publication 9, Pergamon Press, NY. 
Internationa1 Commission on Radiological Protection (ICRP). 1966 a. Deposition and Retention Models for Internal Dosimetry of the Human Respiratory Tract. Heaith Phys. 12:173-207.

Internation Commission on Radiological Protection (ICRP). 1977. Recomendations of the International Commission on Radiological Protection. ICRP Publication 26, Pergamon Press, NY.

Killoash, G. G., D. E. Dunning, Jr., S. R. Bernard, and J. C. Pleasant. 1978. Estimates of Internal Dose Equivalent to 22 Target Organs for Radionuclides Occurring in Routine Releases from Nuc lear Fuel-Cycle Facilities. NUREG/CR-0150, report prepared for the NRC by Oak Ridge National Laboratory, Oak Ridge, TN. **

Milham, R. C., et. al., 1975. "Measured Plutonium Resuspension and Resulting Dose from Agricultural Operations on an 01d Field at the Savannah River Plant in the Southeastern United States." IAEA/USERDA International Symposium on Transuranic Nuclides in the Environment. IAEA-SM-199/83.

Mishima, J. and J. C. Schwendiman, 1972. "Airborne Release of Plutonium and Its Compounds During Overheating Accidents." In Pacif ic Northwest Laboratory Annual Report for the DOE Ass istant Secretary for the Environment, Part I, Biology and Medicine, Pp. 82-87, BNWL-1651, Pacif ic Northwest Laboratory, Rich land, WA.

Mishima, J. and L. C. Schwendiman, 1973. Fractional Airborne Release of Uranium (Representing Plutonium) During the Burning of Contaminated Waste. BNWL-1730, Pacific Northwest Laboratory, Richland, WA.

Murphy, E. S., and G. M. Holter. 1980. Technology, Safety and Costs of Decormissioning a Reference Low-Level Waste Burial Ground. NUREG/ CR-0570, Vols. 1 and 2, report prepared for the NRC by Pac if ic Northwest Laboratory, Richland, WA. *

Napier, B. A., R. L. Roswe 11, W. E. Kennedy, Jr., and D. L. Strenge. 1980. ARRRG and FOOD - Computer Programs for Calculating Radiation Dose to Man from Radionuclides in the Environment. PNL-3180, Pacific Northwest Laboratory, RichTand, WA.

Oak, H. D., G. M. Holter, W. E. Kennedy, Jr., and G. J. Konzek. 1980. Technology, Safety and Costs of Decommissioning a Reference Boiling Water Reactor Power Station. NUREG/CR-0672, Vols. I and 2, report prepared for the NRC by Pacific Northwest Laboratory, Richland, WA. *

Rhoads, R. E. 1977. An Overview of Transportation in the Nuclear Fuel Cycle. BNWL-2066, Pacific Northwest Laboratory, Richland, WA. 
Schneider, K. J. and C. E. Jenkins. 1977. Technology, Safety and Costs of Decommissioning a Reference Nuclear Fuel Reprocessing Plant.

NUREG-0278, Vols. 1 and 2 , report prepared for the NRC by Pacif ic Northwest Laboratory, Richland, WA. $\star \star$

Sehme 1, G. A. 1974. "Particle Resuspension from an Asphalt Road," Atmosphere-Surface Exchange of Particulate and Gaseous Pollutants. CONF-740921.

Sehme1, G. A. 1976. "Particle Resuspension from Truck Traffic in a Cheat Grass Area." In Pacific Northwest Laboratory Annual Report for 1975 to the DOE Assistant Secretary for the Environment, Part 3, Atmospheric Sciences, pp. 96-98, BNWL-2000, Pacific Northwest Laboratory, Richland, WA.

Sehme 1, G. A. and F. D. Lloyd. 1976. "Resuspension Rates from a Circular Field Source." In Pacific Northwest Annual Report for 1975 to DOE Assistant Secretary for the Environment, Part 3, Atmospher ic Sciences, pp. 92-93, BNWL-2000, Battelle, Pac if ic Northwest Laboratory, Richland, WA.

Slade, D. H., ed. 1968. Meteorology and Atomic Energy. U.S. AEC, Division of Technical Information.

Stewart, K. 1964. "The Resuspension of Particulate Material from Surfaces." Proceedings of the Surface Contamination Symposium, pp. 63-74, Gatlinburg, TN.

10CFR 20. 1980. U.S. Code of Federal Regulations. Title 10, Part 20, "Standards for Protection Against Radiation," Government Printing Office, Washington, DC.

U.S. Atomic Energy Commission. 1974. Assumptions Used for Evaluating the Potential Radiological Consequences of a Loss of Coolant Accident for Boiling Water Reactors. Regulatory Guide 1.3, Revision 2, USAEC.

*Available for purchase from the NRC/GPO Sales Progran, U.S. Nuclear Regulatory Commission, Washington, $O C$ 20555, and/or the National Technical Information Service, Springfield, VA 22161.

$\star \star A v a i l a b l e$ for purchase from the National Technical Information Service. 


\section{ECONOMIC COST ANALYSIS}

Cost-benefit analys is is a technique which is beginning to find increasing use in many areas of scientific research, including health systems analysis (Klarman 1973). The problem of analyzing removable surface contamination levels for radioactive materials transportation containers is a type of health systems problem, in that the primary reasons for establishing maximum contamination limits are health protection for workers and the general public and prevention of the spread of radioactive contamination. In applying cost-benefit analys is to this problem, the costs of reducing allowable removable surface contamination levels should be weighed against the health benefits to be gained from this reduction.

The health benefits to be gained from reducing removable surface contamination limits are not measured in an economic sense in this study. Attaching a dollar value to health benefits is a complex problem involving bidding schemes and other techniques which are beyond the scope of this study. The health impacts in terms of radiation doses of reducing the limits were considered in Chapter 3 . The purpose of this Chapter is to provide information on the economic costs of reducing removable surface contamination limits, so that at least a genera? comparison between economic costs and health benefits is possible.

The direct economic costs of reducing removable surface contamination limits are divided into three distinct categories: monitoring time costs to demonstrate compliance with new 1 imits, monitoring instrumentation capital costs for demonstrating compliance, and decontamination costs. Direct cost measurements are done on the bas is of information obtained from industrial representatives and theoretical cost modeling. 
Detailed questions were asked of industry representatives to obtain quantitative information that would be useful in measuring direct costs. Thus, all cost information given in this chapter is based on constant 1980 dollars. All assumptions made in the cost calculations are clearly stated. Direct costs are measured quantitatively for both containers and vehicles. While the indirect costs of reducing contamination limits (including production delays, etc.) were not quantified, some qualitative statements on these indirect costs are included at the end of this chapter.

\subsection{Monitoring Time Costs}

It is believed that monitoring time costs to demonstrate compliance will constitute a substantial proportion of the direct economic costs of reducing removable surface contamination limits. While some containers may have to be decontaminated as a result of modified limits, theoretically every container will have to be monitored more closely to demonstrate compliance with the new limits. Some writers have taken the position that modifying the limits would have little impact on the labor costs of monitoring, as with slight modification of smearing techniques, current instruments would be able to detect levels 100 times below the current levels with few problems (Nickols 1978). Nickols advocates limits that are as low as "reasonably achievable". What is reasonably achievable, however, depends to a great degree on the amount of money a firm spends for monitoring time and instrumentation. Clark (1975) states that the costs of maintaining ALARA conditions may be quite large, especially when indirects costs are included.

Dickson et al. (1980) reported that the costs of performing a radiation survey increase with decreasing dose limits and that the cost can be very high for a survey near the state-of-the-art detection limits. His study also reports that there is a dose limit so low that no amount of expenditure could produce a satisfactory confirmation that the radiation levels are below this limit. 
A primary cost component of monitoring costs is the amount of time spent in taking and counting the removable surface contamination smear. While the amount of time spent taking the smear does not vary much with the allowable levels for removable contamination, the amount of time spent counting the smear to verify compliance with the levels may vary a great dea?.

Several factors influence the ability to detect the levels of radiation required to demonstrate compliance with removable surface contamination limits. These factors include the level of background radiation, the specific activity of the radiation source, the types and energies of the radiation emitted from the source, the source-detector geometry, the instrument time constant, the speed at which the detector probe is moved across the source, and the detection efficiency of the instrument used. Recent studies have addressed the problem of measuring radioactive contamination with common field instrumentation (Bush and Handal 1971; Sommers 1975; I les et al. 1977). In general these studies have reported that special problems arise when low-energy emitting radionuclides are present in the mixtures.

The counting time required to achieve a given counting error can be derived from the basic equations for a Poisson distribution. For a Poisson distribution, the mean value equals the variance $\left(m \simeq \sigma^{2} \simeq n\right.$, , and if $n$ is the number of counts recorded by an instrument over time $t$ the counting rate is $r=n / t$. The count rate \pm its standard deviation is:

$$
r \pm \sigma_{r}=\frac{n}{t} \pm\left(\frac{n}{t}\right)^{1 / 2}=r \pm\left(\frac{r}{t}\right)^{1 / 2}
$$

In terms of percentage error:

$$
r \pm \frac{100}{(r t)^{1 / 2^{2}}} \%=r \pm \frac{100}{n^{1 / 2}} \%
$$


Thus, the percentage error of a counting measurement is determined by the total number of counts accumulated (Price 1964).

When several independent quantities are combined by addition or subtraction, the standard deviation is:

$$
\sigma_{s}=\left(\sigma_{1}^{2}+\sigma_{2}^{2}+\ldots \sigma_{n}^{2}\right)^{1 / 2} \text {. }
$$

Thus, for a background counting rate of $r_{b} \pm \sigma_{b}$ and a total counting rate (source plus background) of $r_{T} \pm \sigma_{T}$, the source counting rate is:

$$
r_{S} \pm \sigma_{S}=\left(r_{T}-r_{b}\right) \pm\left(\sigma_{b}^{2}+\sigma_{T}{ }^{2}\right)^{1 / 2} \text {. }
$$

By substitution from Equation 4.1 into Equation 4.3:

$$
\sigma_{S}=\left(\frac{r_{b}}{t_{b}}+\frac{r_{T}}{t_{T}}\right)^{1 / 2} \text {. }
$$

To determine the optimum use of counting time, Equation 4.5 is differentiated with respect to time, and solved for minimum error $\left(\mathrm{d} \sigma_{\mathrm{s}} / \mathrm{dt}=0\right)$ assuming a constant time $\left(t_{b}+t_{T}=a\right.$ constant) (Price 1964). The result is:

$$
\frac{t_{b}}{t_{T}}=\left(\frac{r_{b}}{r_{T}}\right)^{1 / 2} \text {. }
$$

The relative counting error, $d$, is found by:

$$
d=\frac{\sigma s}{r_{s}}=\frac{\sigma s}{\left(r_{T}-r_{b}\right)}=\frac{\left(r_{b} / t_{b}+r_{T} / t_{T}\right)^{1 / 2}}{\left(r_{T}-r_{b}\right)} .
$$

Solving this equation for the sample counting time, $t_{T}$, using Equation 4.6 gives: 


$$
t_{T}=\frac{\left[1+\left(\frac{r_{b}}{r_{T}}\right)^{1 / 2}\right]}{r_{T} d^{2}\left(1-\frac{r_{b}}{r_{T}}\right)^{2}}
$$

Thus, the required counting time associated with various levels of contamination for given relative counting error, $d$, can be estimated. However, in the field it is difficult to maintain a constant sourcedetector geometry that matches the time constant of the instrument used when long counting times are required. Detector response can be improved by lowering the background count rate, but this usually means that a laboratory with a shielded counting volume is required. The selection of a more sensitive detector can also improve detection ability and reduce the time required to achieve the necessary detection level.

Because of uncertainty and variation in the parameters of the counting time equation, a scenario approach is followed in this study. Monitoring time cost calculations are estimated for five scenarios involving assumptions concerning the detection efficiency of the detection instrument, the background radiation count rate at the time the sample radiation count is undertaken $\left(r_{b}\right)$, the smearing technique used, the mix of beta and gamma radiation in the sample, the costs per hour for monitoring, and the acceptable relative counting error of the counting measurement $(d)$.

So far as possible, each scenario is constructed on the basis of instruments and techniques that are currently being used or are currently available for use in the industry. A summary of data used in the five monitoring time scenarios considered in this study is shown in Table 4.1-1. Each of the assumptions and how they are arrived at will be described in detail in the following sections. 
TABLE 4.1-1. Summary of the Data Used in the Monitoring Time Scenarios

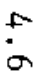

\begin{tabular}{|c|c|c|c|c|}
\hline \multicolumn{3}{|c|}{ Beta-Ganma } & \multicolumn{2}{|c|}{ Alpha } \\
\hline Background (CPM) & $\begin{array}{l}\text { 4" Beta Detection } \\
\text { Efficiency (:) }\end{array}$ & $\begin{array}{l}\text { 4r-Ganma Detection } \\
\text { Efficiency }(\%) \\
\end{array}$ & Background (CPM) & $\begin{array}{l}\text { 4r Alpha Detection } \\
\text { Efficiency }(x)\end{array}$ \\
\hline 25 & 50 & 0.3 & 2 & 50 \\
\hline 120 & 32 & 0.2 & 4 & 32 \\
\hline 30 & 18 & 0.15 & 3 & 18 \\
\hline 200 & 17 & 0.12 & 7 & 18 \\
\hline 250 & 17 & 0.08 & 8 & 15 \\
\hline
\end{tabular}

Fully-Burdened Costs (a)
(Dollars per hour)
$\begin{array}{ccc}\text { Low } & \text { Middle } & \text { High } \\ 22 & 30 & 39 \\ 22 & 30 & 39 \\ 21 & 29 & 37 \\ 20 & 27 & 35 \\ 20 & 27 & 35\end{array}$

(a)All casts are based on 1980 dollars. 


\subsubsection{Detection Efficiency}

Assumptions regarding the detection efficiency of radiation detection instruments are constructed on the bas is of information gathered from conversations with industrial radiation safety personnel and from instrument manufacturers' specifications.

Detection efficiencies vary according to whether the counting is done under laboratory conditions or with portable instruments in the field. Detection efficiencies also vary with the amount of radioactive energy emitted from the isotope that is being sampled. Most detection efficiencies are measured and listed for the isotope ${ }^{90} \mathrm{Sr}$. Because this isotope is a cormon one, the detection efficiencies for it were used as basis for the efficiencies defined for use in the scenarios. However, the scenario estimates were lowered slightly to reflect the fact that ${ }^{90} \mathrm{Sr}$ has a relatively high energy leve1, causing its detection efficiencies to be higher than those of other isotopes.

According to instrument specification information sheets obtained from industrial contancts, a $4 \pi$ counting geometry efficiency of 50 to 55 percent is about the highest efficiency obtainable from commonly used stationary laboratory instruments. The lower bound on this estimate is used as the counting efficiency in Scenario 1 for both beta and alpha radiation.

Manufacturer's specifications indicated that the highest efficiency obtainable from a semi-portable detector is between 32 and 39 percent. These detectors are of the same type as those used in determining frequency distributions in Chapter 5. The lower bound on the above estimate is used as the counting efficiency for both beta and alpha radiation in Scenario 2 .

The primary advantage of a shielded detector is the reduction of background radiation. The efficiency of portable shielded detectors is 
reported to be between 15 and 20 percent which is not much higher than that obtainable from most handheld probes. Thus, a detection efficiency of 18 percent was chosen for Scenario 3 for both beta and alpha radiation.

The final two scenarios involved obtaining efficiencies for simple handheld field instruments. On the bas is of manufacturer's specifications, efficiencies of 17 percent for beta detection and 18 to 15 percent for alpha detection were chosen for these scenarios.

The counting efficiency for gamma radiation is generally much lower than the counting efficiency for beta and alpha radiation. According to industrial sources the highest gamma detection efficiency that can be expected from a detector which may also be used for beta radiation detection is about 0.3 percent. Higher efficiencies may be obtained from sophisticated counting systems using sodium iodide or lithium drifted germanium diode detectors with single or multi-channel analyzers, but such instruments are normally found only at facilities which handle large amounts of gamma sources, and these instruments are rarely used for contamination detection. This is because it is rare that a facility uses or transports pure gamma-emitters, and most facilities rely on detecting the beta components in a given surface contamination mixture. Thus, 0.3 percent is selected as the ganma detection efficiency for Scenario 1 , and efficiencies of $0.2,0.15$, and 0.12 and 0.08 percent are chosen for the other scenarios.

\subsubsection{Background Radiation}

In uncontrolled environments, the background radiation count will vary according to counting site location, the day the count is taken, and even the $t$ ime of day the count is taken. Thus, all background counts described below are simply "typical average" background counts. 
The background count for beta-gamma radiation in a field situation, according to our industrial sources, normally varies from 120 counts per minute to $250 \mathrm{cpm}$. Because all scenarios except Scenario 1 are field situations, the assumed background counts are $120 \mathrm{cpm}$ for Scenario 2, and 200 and $250 \mathrm{cpm}$ for Scenarios 4 and 5. Because Scenario 3 assumes a portable shielded detector is used, a background count of $30 \mathrm{cpm}$ is used for this scenario. Scenario 1 (the laboratory situation) assumes a background count of $25 \mathrm{cpm}$.

Information on alpha radiation background counts was difficult to obtain, since at most facilities alpha background is assumed to be so low that it is not normally measured. For scenario construction, alpha background counts varying between 2 and $8 \mathrm{cpm}$, are selected for the five scenarios.

\subsubsection{Smearing Technique}

Smearing techniques may vary tremendously depending on the type of container being analyzed, company policy, and even the individual taking the smear. For purposes of this study, however, the assumed smearing techn ique used is based on 49 CFR 173.389(f) and 173.397(a). These regulations stipulate the amount of allowable radiation in terms of a $300 \mathrm{~cm}^{2}$ area and thus this study assumes that a smear is taken over only this amount of surface area. The allowable limits of 66,000 disintegrations per minute for beta-garma radiation and $6600 \mathrm{dpm}$ for alpha radiation on each smear covering $300 \mathrm{~cm}^{2}$ are assumed. Counting times are estimated down to $66 \mathrm{dpm}$ with a $10 \%$ relative counting error for the various scenarios, using Equation 4.8. No analysis was attempted to describe smear collection efficiencies.

\subsubsection{Mix of Beta-Ganma Radiation}

Current regulations are stated in terms of beta-garma removable contamination levels, but the characteristics and counting efficiencies for beta radiation and ganma radiation are markedly different. In 
practice, what is usually done in measuring smearable contamination on transported containers is to concentrate on beta radiation and place less emphasis on determining the amount of gamma radiation that may be present. Thus, an arbitrary mix of 95 percent beta radiation and 5 percent gamma radiation was assumed for all scenarios. Aggregate counting efficiencies were computed for beta-gamma radiation, but assuming only 5 percent gamma radiation caused these aggregate efficiencies to differ little from the beta radiation efficiencies listed previously. A higher percentage of gamma radiation than what is assumed will lower the counting efficiencies and raise the counting times above the equation estimates. However, in practice mixtures of beta emitters are far more common sources of surface contamination than pure gamma emitters.

\subsubsection{Monitoring Costs Per Hour}

In an effort to ascertain the true costs of monitoring time, a concept known as the "fully burdened" cost is utilized. Fully burdened costs reflect the total costs of business operation including taxes, overhead, and maintenance of equipment, as well as labor wage costs. In essence, the fully burdened cost of monitoring assumed in this study reflect the total costs of radiation monitoring to the firm, except for the capital costs of the radiation detection instruments. All fully burdened costs are estimated based on 1980 dollars.

Some of the firms contacted could not provide any information on their fully burdened costs of monitoring. Of those that could provide this information, the costs of monitoring ranged from $\$ 25$ an hour to $\$ 40$ an hour. All firms contacted were able to provide their labor wage costs for monitoring. Comparison of the labor wage costs for the firms that were able to provide a fully burdened cost figure to those that were not revealed that labor wage costs were generally lower for those firms that were not able to provide a fully burdened cost figure. Thus, fully burdened costs in the scenarios are lowered slightly from what the 
respondents reported to reflect the results of this comparison. The five cost scenarios are estimated for base fully burdened costs of $\$ 20, \$ 27$, and $\$ 35$ per hour, modified for instrument technical complexity.

In addition, it was felt by many (though not all) of the industrial respondents that hourly costs rise as the technical complexity of the detection operation is increased. To reflect this assertion, the fully burdened base costs listed above are raised by approximately 10 percent for Scenarios 1 and 2 and by approximately 6 percent for Scenario 3 since the technical complexity of the instruments is somewhat higher for these scenarios.

\subsubsection{Relative Counting Error of the Counting Measurement}

An arbitrary relative counting error of $5 \%$ is assumed for all scenarios. While this level of error maybe high for most laboratory testing, it is probably low relative to most field testing. The assumed level is thought to be an appropriate average.

\subsubsection{Monitoring Cost Results}

The monitoring time and monitoring costs per smear for the five scenarios and three cost cases for the various levels of removable contamination are presented in Tables 4.1-2 through 4.1-5.

The data in these tables indicate that the monitoring costs per smear for counting time are quite low under the current regulations. The highest costs per smear calculated under the current regulations for beta-garma (Table 4.1-2) and for alpha (Table 4.1-3) given the scenario assumptions, are $\$ 0.03$ and $\$ 0.26$ (Scenario $5-\$ 35$ Cost).

Decreasing the current limits for beta-ganma by 10 times (Table 4.1-3) allows the costs per smear to remain fairly low at $\$ 0.39$ per smear in the worst case (Scenario 5 - $\$ 35$ Cost). The counting time is still below 1 minute, and thus this surface contamination level could be detectable with handheld field instruments. 
TABLE 4.1-2. Counting Times and Counting Costs Per Sample at Current DOT Beta-Ganma Limits $\left(10^{-4} \mu \mathrm{Cj} / \mathrm{cm}^{2}\right)$

\begin{tabular}{|c|c|c|c|c|c|}
\hline Beta-Gamma & $\begin{array}{c}\text { Scenario } \\
1 \\
\end{array}$ & $\begin{array}{l}\text { Scenario } \\
? \\
\end{array}$ & $\begin{array}{c}\text { Scenario } \\
-3 \\
\end{array}$ & $\begin{array}{c}\text { Scenario } \\
4\end{array}$ & $\begin{array}{c}\text { Scenario } \\
5 \\
\end{array}$ \\
\hline Counting Time & $0.8 \mathrm{sec}$ & $1.3 \mathrm{sec}$ & $2.24 \mathrm{sec}$ & $2.6 \mathrm{sec}$ & $2.65 \mathrm{sec}$ \\
\hline $\begin{array}{l}\text { Costs Per Sample } \\
(\$ 20 \text { Base Cost) }\end{array}$ & $\$ 0.01$ & $\$ 0.01$ & $\$ 0.01$ & $\$ 0.01$ & $\$ 0.01$ \\
\hline $\begin{array}{l}\text { Costs Per Sample } \\
(\$ 27 \text { Base Cost) }\end{array}$ & $\$ 0.01$ & $\$ 0.01$ & $\$ 0.02$ & $\$ 0.02$ & $\$ 0.02$ \\
\hline $\begin{array}{l}\text { Costs Per Sample } \\
\text { ( } \$ 35 \text { Base Cost) }\end{array}$ & $\$ 0.01$ & $\$ 0.01$ & $\$ 0.02$ & $\$ 0.03$ & $\$ 0.03$ \\
\hline \multicolumn{6}{|l|}{ Alpha (a) } \\
\hline Counting Time & $0.7 \mathrm{sec}$ & $1.2 \mathrm{sec}$ & $1.85 \mathrm{sec}$ & $2.1 \mathrm{sec}$ & $2.5 \mathrm{sec}$ \\
\hline $\begin{array}{l}\text { Costs Per Sample } \\
(\$ 20 \text { Base Cost })\end{array}$ & $\$ 0.01$ & $\$ 0.01$ & $\$ 0.01$ & $\$ 0.01$ & $\$ 0.01$ \\
\hline $\begin{array}{l}\text { Costs Per Sample } \\
(\$ 27 \text { Base Cost })\end{array}$ & $\$ 0.01$ & $\$ 0.01$ & $\$ 0.01$ & $\$ 0.02$ & $\$ 0.02$ \\
\hline $\begin{array}{l}\text { Costs Per Sample } \\
\text { ( } \$ 35 \text { Base Cost) }\end{array}$ & $\$ 0.01$ & $\$ 0.01$ & $\$ 0.02$ & $\$ 0.03$ & $\$ 0.03$ \\
\hline
\end{tabular}

(a) These values are for a factor of 10 times higher than the current DOT alpha limits.

TABLE 4.1-3. Counting Times and Counting Costs Per Sample at Levels 10 Times Below Current DOT Beta-Gamma Limits $\left(10^{-5} \mu \mathrm{Ci} / \mathrm{cm}^{2}\right)$

\begin{tabular}{|c|c|c|c|c|c|}
\hline Beta-Garma & $\begin{array}{c}\text { Scenario } \\
1 \\
\end{array}$ & $\begin{array}{c}\text { Scenario } \\
2 \\
\end{array}$ & $\begin{array}{c}\text { Scenario } \\
3 \\
\end{array}$ & $\begin{array}{l}\text { Scenario } \\
4 \\
\end{array}$ & $\begin{array}{c}\text { Scenario } \\
5 \\
\end{array}$ \\
\hline Counting Time & $8.4 \mathrm{sec}$ & $15.7 \mathrm{sec}$ & $25.3 \mathrm{sec}$ & $37.4 \mathrm{sec}$ & $39.9 \mathrm{sec}$ \\
\hline $\begin{array}{l}\text { Costs Per Sample } \\
(\$ 20 \text { Base Cost })\end{array}$ & $\$ 0.05$ & $\$ 0.10$ & $\$ 0.15$ & $\$ 0.21$ & $\$ 0.22$ \\
\hline $\begin{array}{l}\text { Costs Per Sample } \\
\text { ( } \$ 27 \text { Base Cost) }\end{array}$ & $\$ 0.07$ & $\$ 0.13$ & $\$ 0.20$ & $\$ 0.28$ & $\$ 0.30$ \\
\hline $\begin{array}{l}\text { Costs Per Sample } \\
(\$ 35 \text { Base Cost) }\end{array}$ & $\$ 0.09$ & $\$ 0.17$ & $\$ 0.26$ & $\$ 0.36$ & $\$ 0.39$ \\
\hline \multicolumn{6}{|l|}{ Alphata } \\
\hline Count ing Time & $7.5 \mathrm{sec}$ & $11.9 \mathrm{sec}$ & $19.1 \mathrm{sec}$ & $21.9 \mathrm{sec}$ & $26.6 \mathrm{sec}$ \\
\hline $\begin{array}{l}\text { Costs Per Sample } \\
(\$ 20 \text { Base Cost) }\end{array}$ & $\$ 0.05$ & $\$ 0.07$ & $\$ 0.11$ & $\$ 0.12$ & $\$ 0.15$ \\
\hline $\begin{array}{l}\text { Costs Per Sampie } \\
(\$ 27 \text { Base Cost })\end{array}$ & $\$ 0.06$ & $\$ 0.10$ & $\$ 0.15$ & $\$ 0.16$ & $\$ 0.20$ \\
\hline $\begin{array}{l}\text { Costs Per Sample } \\
\text { ( } \$ 35 \text { Base Cost) }\end{array}$ & $\$ 0.08$ & $\$ 0.13$ & $\$ 0.20$ & $\$ 0.21$ & $\$ 0.26$ \\
\hline
\end{tabular}


IABLE 4.1-4. Counting Times and Counting Costs Per Sample at Levels 100 Times Below Current DOT Beta-Ganma Limits $\left(10^{-6} \mathrm{uCi} / \mathrm{cm}^{2}\right)$

\begin{tabular}{|c|c|c|c|c|c|}
\hline Beta-Ganma & $\begin{array}{c}\text { Scenario } \\
1 \\
\end{array}$ & $\begin{array}{c}\text { Scenario } \\
2 \\
\end{array}$ & $\begin{array}{c}\text { Scenario } \\
3\end{array}$ & $\begin{array}{c}\text { Scenario } \\
4\end{array}$ & $\begin{array}{c}\text { Scenario } \\
5\end{array}$ \\
\hline Counting Time & $1.75 \mathrm{~min}$ & $5.13 \mathrm{~min}$ & $6.54 \mathrm{~min}$ & 19.5 min & $23.1 \mathrm{~min}$ \\
\hline $\begin{array}{l}\text { Costs Per Sample } \\
(\$ 20 \text { Base Cost })\end{array}$ & $\$ 0.64$ & $\$ 1.88$ & $\$ 2.29$ & $\$ 6.50$ & $\$ 7.69$ \\
\hline $\begin{array}{l}\text { Costs Per Sample } \\
(\$ 27 \text { Base Cost })\end{array}$ & $\$ 0.88$ & $\$ 2.57$ & $\$ 3.16$ & $\$ 8.77$ & $\$ 10.38$ \\
\hline $\begin{array}{l}\text { Costs Per Sample } \\
(\$ 35 \text { Base Cost) }\end{array}$ & $\$ 1.14$ & $\$ 3.34$ & $\$ 4.03$ & $\$ 11.37$ & $\$ 13.45$ \\
\hline
\end{tabular}

$\begin{array}{lccccc}\text { Alpha(a) } & & & & & \\ \text { Counting Time } & 1.31 \mathrm{~min} & 2.19 \mathrm{~min} & 3.56 \mathrm{~min} & 4.41 \mathrm{~min} & 5.56 \mathrm{~min} \\ \begin{array}{l}\text { Costs Per Sample } \\ (\$ 20 \text { Base Cost) }\end{array} & \$ 0.48 & \$ 0.80 & \$ 1.25 & \$ 1.47 & \$ 1.85 \\ \begin{array}{l}\text { Costs Per Sample } \\ (\$ 27 \text { Base Cost) }\end{array} & \$ 0.66 & \$ 1.10 & \$ 1.72 & \$ 1.98 & \$ 2.50 \\ \begin{array}{l}\text { Costs Per Sample } \\ (\$ 35 \text { Base Cost) }\end{array} & \$ 0.85 & \$ 1.43 & \$ 2.20 & \$ 2.57 & \$ 3.24\end{array}$

(a) These values are for a factor of 10 below current Dot aipha limits.

TABLE 4.7-5. Counting Times and Counting Costs Per Sample at Levels 1000 Times Below Current DOT Beta-Gamma Limits $\left(10^{-7} \mu \mathrm{C} . \mathrm{i} / \mathrm{cm}^{2}\right)$

\begin{tabular}{|c|c|c|c|c|c|}
\hline Beta-Ganma & $\begin{array}{c}\text { Scenario } \\
1 \\
\end{array}$ & $\begin{array}{l}\text { Scenario } \\
\quad 2 \\
\end{array}$ & $\begin{array}{c}\text { Scenario } \\
-3\end{array}$ & $\begin{array}{c}\text { Scenario } \\
4\end{array}$ & $\begin{array}{c}\text { Scenario } \\
\quad 5 \\
\end{array}$ \\
\hline Counting Time & $38.19 \mathrm{~min}$ & $4.46 \mathrm{hr}$ & $4 \mathrm{hr}$ & $24.4 \mathrm{hr}$ & $75.6 \mathrm{hr}$ \\
\hline $\begin{array}{l}\text { Costs Per Sample } \\
(\$ 20 \text { Base Cost) }\end{array}$ & $\$ 14.00$ & $\$ 98.20$ & $\$ 83.99$ & $\$ 487.75$ & $\$ 605.18$ \\
\hline $\begin{array}{l}\text { Costs Per Sample } \\
(\$ 27 \text { Base Cost })\end{array}$ & $\$ 19.10$ & $\$ 133.91$ & $\$ 115.99$ & $\$ 658.46$ & $\$ 817$ \\
\hline $\begin{array}{l}\text { Costs Per Sample } \\
(\$ 35 \text { Base Cost) }\end{array}$ & $\$ 24.82$ & $\$ 174.09$ & $\$ 147.99$ & $\$ 853.56$ & $\$ 1059.07$ \\
\hline \multicolumn{6}{|l|}{ Alpha (a) } \\
\hline Counting Time & $15.93 \mathrm{~min}$ & $31.52 \mathrm{~min}$ & $53.19 \mathrm{~min}$ & $1.43 \mathrm{hr}$ & $2.03 \mathrm{hr}$ \\
\hline $\begin{array}{l}\text { Costs Per Sample } \\
(\$ 27 \text { Base Cost) }\end{array}$ & $\$ 5.84$ & $\$ 11.56$ & $\$ 18.62$ & $\$ 28.70$ & $\$ 40.63$ \\
\hline Costs Per Sample & $\$ 10.35$ & $\$ 20.49$ & $\$ 32.80$ & $\$ 50.22$ & $\$ 71.10$ \\
\hline
\end{tabular}

(a) These values are for a factor of 100 below current DOT aipha limits. 
If the limits for alpha are lowered to 10 times below the current limits, however, the counting times would increase to a point where handheld probes would no longer be a valid means of counting. Holding a sample over a handheld probe for more than a minute would probably not be feasible because of cost and accuracy considerations. Thus, we assume that for levels requiring counting times longer than 1 minute, a firm would require more complex instruments than simple handheld probes. In addition, for any counts longer than 1 minute, we assume a scaler would be necessary to accurately verify beta-gamma and alpha levels for every scenario except Scenario 1, where the complexity of the counting instrument would negate the need for an additional scaler instrument. With the above criteria, counters in Scenarios 1, 2 and 3 remain valid detection methods because they do not involve the used of handheld probes, while Scenarios 4 and 5 are eliminated. The lowest possible cost per sample for alpha at 10 times below current levels (Table 4.1-4) are $\$ 0.48$ (Scenario $1-\$ 22 \operatorname{Cos} t$ ), which is greater than the highest calculated cost for beta-gama in moving to 10 times below current limits.

Moving to 100 times below the current limits would cause substantial monitoring time cost increases for both beta-gamma (Table 4.1-4) and alpha radiation (Table 4.1-5). The lowest possible costs in moving to these limits for beta-gamma are \$0.64 per sample for the highly complex detection instruments assumed in Scenario 1. The lowest possible costs for alpha are $\$ 5.84$ per sample. The cost impacts of verifying compliance to 1000 times below the current limits are shown only for betagamma and they would be very substantial. It is also questionable whether detection of this level of radiation would even be technically feasible for any of the assumed scenarios except Scenario 1, given counting times of 4 hours or more.

Converting the time of counting per smear to a time of counting per container is not straightforward. Different firms use different 
sampling techniques and may take one or many smears from an individual container. In addition, not every container in an individual shipment is always smeared, but randomized checking procedure may be used.

A simplifying assumption for this problem is to assume that one smear is taken on every container shipped for all types of containers, except spent fuel casks. While this assumption might underestimate the time needed to monitor an individual container (because more than one smear is often taken) it would probably overestimate the amount of containers smeared (because not al1 containers are always smeared). Spent fuel casks, however, are a special case. The possibility of contamination on these shipments is higher than for other shipments and thus, they are monitored extensively. The average number of smears taken on spent fue] casks shipped and received is found to be 89 . In this study, we assume that 50 additional smears are taken at the reactor site where the cask shipment originated.

The monitoring time cost impacts of reducing the current limits on a per smear bas is are presented in Table 4.1-6. To estimate the total monitoring cost impacts utilizing the above assumptions, the number of containers shipped in all categories except spent fuel casks should be multiplied by the costs shown in Table 4.1-6. For spent fuel casks, the number of shipments should be multiplied by 139 (the average number of smears taken on a spent fuel cask) and then multiplied by the costs shown in Table 4.1-6.

A problem arises in determining total impacts because it is difficult to predict which scenario is most likely to occur. While monitoring time costs decrease from Scenario 5 to Scenario 1 because of increased detection efficiency and reduced background, the capital costs necessary to purchase the instruments which provide these conditions increase. Thus, there appears to be a tradeoff between higher capital costs necessary to purchase technically complex detection instruments and the lower 


\section{TABLE 4.1-6. Suggested Monitoring Cost Impacts per Smear of Lowering Removable Contamination Levels for Alpha and Beta-Gamma to 10 and 100 Times Below Current Limits}

Monitoring Costs at Levels 10 Times Below Current Limits (1980 Dollars)

\begin{tabular}{|c|c|c|c|c|c|c|c|}
\hline Cost & Changes Per & Sample & Scenario 1 & Scenario? & Scenario 3 & Scenario 4 & Scenario 5 \\
\hline $\begin{array}{l}\text { Cost } \\
1 \$ 20\end{array}$ & $\begin{array}{l}\text { Changes Per } \\
\text { Base Cost) }\end{array}$ & Sample & $\$ 0.05$ & $\$ 0.09$ & $\$ 0.14$ & $\$ 0.20$ & $\$ 0.20$ \\
\hline $\begin{array}{l}\text { Cost } \\
(\$ 27\end{array}$ & $\begin{array}{l}\text { Changes Per } \\
\text { Base Cost) }\end{array}$ & Sample & $\$ 0.06$ & $\$ 0.12$ & $\$ 0.18$ & $\$ 0.26$ & $\$ 0.28$ \\
\hline \multirow[t]{2}{*}{$\begin{array}{l}\text { Cost } \\
(\$ 35\end{array}$} & $\begin{array}{l}\text { Changes Per } \\
\text { Base Cost) }\end{array}$ & Samp le & $\$ 0.08$ & $\$ 0.16$ & $\$ 0.24$ & $\$ 0.33$ & $\$ 0.36$ \\
\hline & Alpha & & & & & & \\
\hline $\begin{array}{l}\text { Cost } \\
(\$ 20\end{array}$ & $\begin{array}{l}\text { Changes Per } \\
\text { Base Cost) }\end{array}$ & Sample & $\$ 0.43$ & $\$ 0.72$ & $\$ 1.14$ & Not Feasible(a) & Not Feasible(a) \\
\hline $\begin{array}{l}\operatorname{Cos} t \\
(\$ 27\end{array}$ & $\begin{array}{l}\text { Changes Per } \\
\text { Base Cost) }\end{array}$ & Samp le & $\$ 0.60$ & $\$ 1.00$ & $\$ 1.57$ & Not Feasible(a) & Not Feasible(a) \\
\hline \multirow[t]{2}{*}{$\begin{array}{l}\operatorname{Cos} t \\
1 \$ 35\end{array}$} & $\begin{array}{l}\text { Changes Per } \\
\text { Base Cost) }\end{array}$ & Samp le & $\$ 0.77$ & $\$ 1.30$ & $\$ 2.00$ & Not Feasible(a) & Not Feasible(a) \\
\hline & & Monitor & Costs at & els $100 \mathrm{~T}$ & s Belaw Cu & nt Limits $(1980$ & $\operatorname{lars})$ \\
\hline
\end{tabular}

\begin{tabular}{|c|c|c|c|c|c|}
\hline \multicolumn{6}{|l|}{ Beta-Gamma } \\
\hline $\begin{array}{l}\text { Cost Changęs Per Sample } \\
(\$ 20 \text { Base Cost }\end{array}$ & $\$ 0.64$ & $\$ 1.87$ & $\$ 2.28$ & Not Feasible(a) & Not Feasible(a) \\
\hline $\begin{array}{l}\text { Cost Changes Per Sample } \\
\text { ( } \$ 27 \text { Base Cost) }\end{array}$ & $\$ 0.87$ & $\$ 2.56$ & $\$ 3.14$ & Not Feasible(a) & Not Feasible(a) \\
\hline $\begin{array}{l}\text { Cost Changes Per Sample } \\
(\$ 35 \text { Base Cost) }\end{array}$ & $\$ 1.13$ & $\$ 3.33$ & $\$ 4.01$ & Not Feasible(a) & Not Feasible(a) \\
\hline \multicolumn{6}{|l|}{ Alpha } \\
\hline $\begin{array}{l}\text { Cost Changes Per Sample } \\
\text { (\$20 Base Cost) }\end{array}$ & $\$ 5.79$ & $\$ 11.49$ & $\$ 18.51$ & Not Feasible(a) & Not FeasibTe(a) \\
\hline $\begin{array}{l}\text { Cost Changes Per Sample } \\
\text { ( } \$ 27 \text { Base Cost) }\end{array}$ & $\$ 7.91$ & $\$ 15.66$ & $\$ 22.74$ & Not Feasible(a) & Not Feasible(a) \\
\hline $\begin{array}{l}\text { Cost Changes Per Sample } \\
\text { ( } \$ 35 \text { Base Cost) }\end{array}$ & $\$ 10.27$ & $\$ 20.33$ & $\$ 32.60$ & Not Feasible $(a)$ & Not Feasible(a) \\
\hline
\end{tabular}

(a) Not feasible with handheld probes because of counting time $>1$ minute. 
monitoring time costs incurred in using these instruments. How firms wi 31 operate given this tradeoff depends on the relative costs of monitoring time and instrumentation at a given contamination level.

\subsection{Instrumentation Costs}

The capital costs for the various instruments that may be used for detection of removable surface contamination vary significantiy. According to the industrial sources contacted, laboratory detectors of the complexity of those assumed in Scenario 1 may cost as much as $\$ 25,000$. Simple handheld detectors and probes of the type assumed in Scenarios 4 and 5 may cost as little as $\$ 500$ for both detector and probe.

A first step in determining the instrumentation costs as a result of reduced limits is to determine what instruments are currently being used for radiation detection and how many of these instruments are necessary to monitor a given number of containers. It is feit that the best source of answers to these questions are obtained through contacts with industrial representatives.

Currently, most industrial sites contacted employ a mix of portable and laboratory instruments. The detection instruments used, the approximate number of containers monitored anually, and estimates of the number of containers monitored per instrument for the industrial sites contacted are presented in Table 4.2-1. Note that Table 4.2-1 contains information for each category of container considered in this study (i.e., shippers of radiopharmaceuticals, industrial sources, nuclear fuel cycle materials, and low-level radioactive wastes).

The measurements of the number of containers handled per instrument are obviously very rough approximations. The number of containers a given instrument may monitor is theoretically very large, but repair time and other considerations will reduce this number in practice. Most firms 
TABLE 4.2-1. Detection Instruments Currently in Use at Representative Industrial Sites

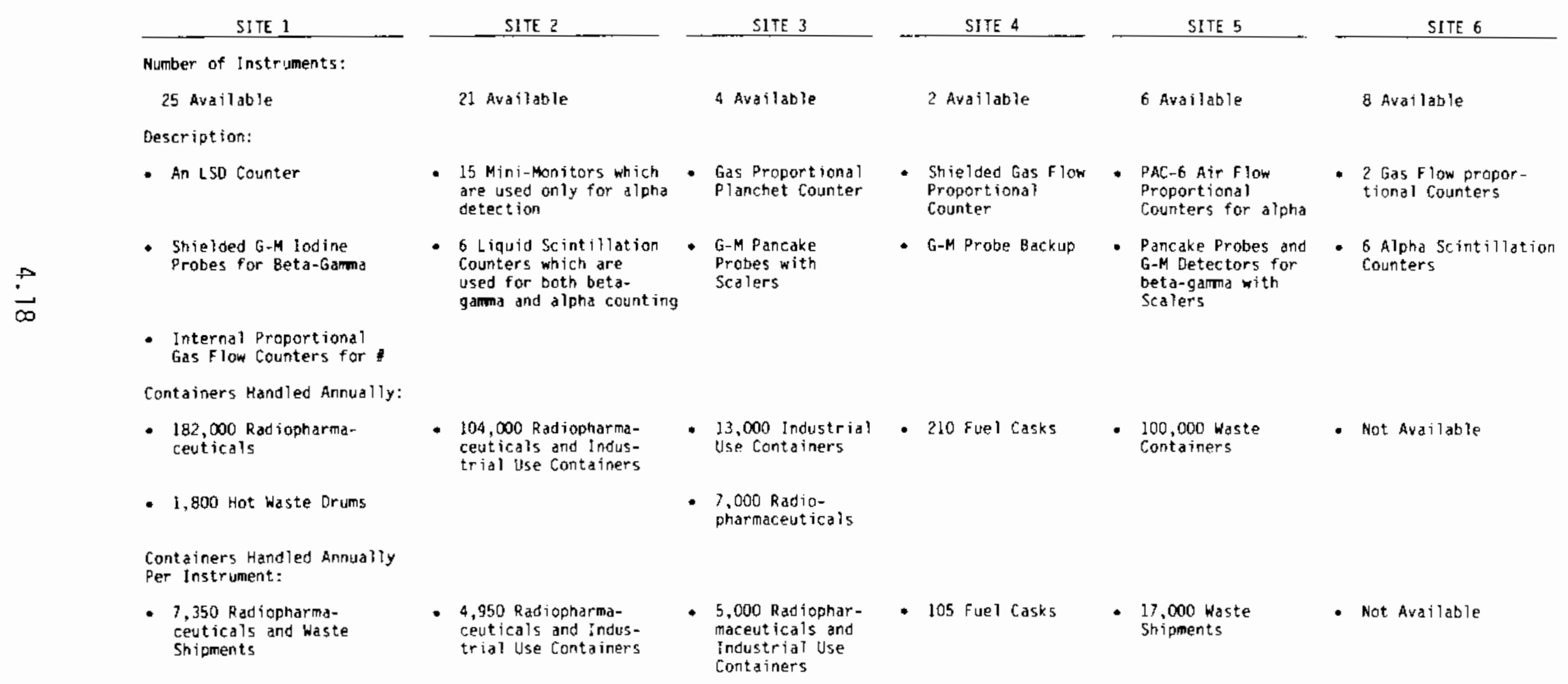


generally have a pool of instruments to draw from so that they will have an adequate number of instruments in peak shipping periods or if some of the ir instruments should break down. Differences in sampling techniques and the radioactivity associated with different types of containers will also cause the frequency of use for detection instruments to vary significantly from one facility to another.

However, in order to estimate the capital costs for monitoring on a per container basis, it is necessary to approximate the number of containers monitored by a typical instrument. The numbers presented in Table 4.2-1 are based in the assumption that every container handled by a firm is monitored with an instrument. While these numbers are only rough estimates, they are based on industry experiences.

In the monitoring time cost calculations, it is assumed that all containers except spent fuel casks are smeared once over a $300 \mathrm{~cm}^{2}$ area, as stated in the current regulations. To maintain consistency with this approach, the frequency of instrument use is assumed to be equal for all types of containers except spent fuel casks. This assumption allows for an averaging of the numbers presented in Table 4.2-1 to yield an average number of approximately 8600 containers (excepting spent fuel casks) monitored per instrument per year. For spent fuel casks, an average number of 105 per year is obtained from reported industrial data.

The useful life of a detection instrument is also a very difficult problem to assess. Varjation in the frequency of use and maintenance practices causes the useful life of a detection instrument to vary from one facility to another. On the basis of information gathered from instrument manufacturers the useful life of a field instrument is assumed to be five years and the useful life of a laboratory instrument is assumed to be seven years. 
Information on the useful life of the instrument may be combined with the annual number of containers monitored by a typical instrument to yield the total number of containers monitored over the useful life of the instrument. In this study, these numbers are 735 spent fuel casks or 60,200 containers of other categories for a laboratory instrument, and 525 spent fuel casks or 43,000 containers in other categories for less complex field instruments.

Using the above numbers, the per container capital costs for the instrumentation assumed in the five scenarios are presented in Table 4.2-2, along with the approximate total capital costs. The numbers in Table 4.2-2 are combined with the numbers in Table 4.1-6 to obtain an idea of how firms would be likely to act given the tradeoffs between the increased capital costs of deciding to use a more complex detection instrument and the reduced monitoring time costs of such a decision.

In reducing the limits to 10 times below the current beta-gamma limits, Scenario 2 would be the least-cost choice for a firm to make. At these limits, scalers are not assumed to be necessary to detect the allowable surface contamination levels. The total cost impacts of reaching this level under Scenario 2 would vary between $\$ 14.31$ and $\$ 24.04$ per container for spent fuel casks (assuming 139 smears) and between $\$ 0.11$ and $\$ 0.18$ per container for all other container categories, the lowest of any of the scenarios (see Table 4.2-3).

In reducing the limits to 10 times below current limits for alpha, Scenario 1 would be the least-cost choice for spent fuel casks, with total cost impacts varying between $\$ 86.98$ and $\$ 134.24$ per cask. For other containers the least-cost choice would depend on the monitoring costs of the firm. At a $\$ 20$ cost of monitoring, Scenarios 1 and 2 would be equal in cost impact at $\$ 0.76$ per container (this assumes a scaler would be necessary to utilize the instrument assumed in Scenario 2). At higher time costs, Scenario 1 would be the least-cost choice. 


\section{IABLE 4.2-2. Approximate Capital Costs for Typical Laboratory and Field}

Radiation Detection Instruments (a)

\begin{tabular}{|c|c|c|c|c|c|c|c|c|}
\hline & $\begin{array}{l}\text { Liguid Scintillation } \\
\text { and other State-of- } \\
\text { the-Art Counters } \\
\text { (7-Year Life) } \\
\end{array}$ & $\begin{array}{c}\text { Unshielded } \\
\text { Chamber } \\
\text { Counters } \\
\text { (betd Crystal) } \\
\text { (7-Year Life) } \\
\end{array}$ & $\begin{array}{l}\text { Unshielded } \\
\text { Chamber } \\
\text { Courters } \\
\text { (Alpha Crystal) } \\
\text { (7-Year Life) }\end{array}$ & $\begin{array}{l}\text { Shielded } \\
\text { Beta-Gamma } \\
\text { Counters } \\
\text { (7-Year Life) }\end{array}$ & $\begin{array}{c}\text { Gas } \\
\text { Proportional } \\
\text { Alpha-Counters } \\
\text { (7-Year Life } \\
\end{array}$ & $\begin{array}{c}\text { Portable } \\
\text { Scalers } \\
\text { (7-Year Life) }\end{array}$ & $\begin{array}{c}\text { Beta-Ganma } \\
\text { Handheld } \\
\text { Detectors } \\
\text { (5-Year Life) } \\
\end{array}$ & $\begin{array}{l}\text { Air } \\
\text { Proportional } \\
\text { Alpho Counters } \\
\text { (5-Year Life) }\end{array}$ \\
\hline $\begin{array}{l}\text { Approx imate } \\
\text { Capital Cost }\end{array}$ & $\$ 20,000$ & $\$ 1,325$ & $\$ 1,325$ & $\$ 1,750$ & 51,200 & $\$ 1,300$ & $\$ 500$ & $\$ 650$ \\
\hline \multicolumn{9}{|c|}{$\begin{array}{l}\text { Costs per Con- } \\
\text { tainer Over the } \\
\text { tife of the } \\
\text { Instrument: }\end{array}$} \\
\hline Fuel Casks & $\$ 27.21$ & $\$ 1.80$ & $\$ 1.80$ & $\$ 2.38$ & $\$ 1.63$ & $\$ 1.77$ & so. 95 & $\$ 1.24$ \\
\hline All others & 50.33 & $\$ 0.02$ & 50.03 & 50.02 & $\$ 0.02$ & $\$ 0.02$ & $\$ 0.02$ & \\
\hline
\end{tabular}

(a) The instrument life for laboratory instruments is defined to be 735 spent fuel casks or 60,200 shipping containers. For field instruments, the instrument life is defined to be 525 spent fuel casks or 43,000 shipping containers. All cost estimates are based on constant 1980 do 7 ars. 
Scenario 1 would be the least-cost choice in reducing the limits to 100 times below current limits for both beta-ganma and aipha. The higher capital costs involved in purchasing instruments of the complexity assumed in Scenario 1 are more than compensated for by the reduced monitoring time costs of using these instruments.

The least-cost amounts for reaching levels 10 and 100 times below the current limits are presented in Tables 4.2-3 and 4.2-4. It is obvious from the results presented in Tables 4.2-3 and 4.2-4 that lower contamination limits would provide significant incentive for a firm to purchase detection instruments with higher detection efficiencies. The differences in monitoring time costs between low and high efficiency instruments clearly outweigh the capital cost differences between the two types. In fact, there is evidence that firms in the industry are already beginning to purchase and use more complex instruments, because of license requirements and other factors not directly related to DOT regulations.

\subsection{Decontamination Costs}

At a first glance, decontamination costs would appear to be a substantial part of the costs of reducing removable surface contamination 1 imits. When a problem is detected related to removable surface contamination, it would seem that the costs of alleviating the problem would be significant. However, under the current limits very few instances of such problems have been discovered and for some types of containers, the direct costs of decontamination are relatively small.

\subsubsection{Radiopharmaceutical and Industrial Source Containers}

Recent surveys indicate that the frequency of decontamination for radiopharmaceuticals and industrial use shipments under the current limits is very low. One survey taken in eight states and New York City found only 2 of 2593 radioactive containers had detectable surface contamination 
TABLE 4.2-3. Least Cost per Container for Reaching Leve1s 10 Times Below Current Limits

Least Cost to Attain Levels 10 Times Below Current Limits (1980 Dollars)

\begin{tabular}{|c|c|c|c|c|}
\hline Beta-Gamma & $\begin{array}{l}\text { Least Cost } \\
\text { Scenario } \\
\text { Number } \\
\end{array}$ & $\begin{array}{l}\text { Monitoring } \\
\text { Time Cost } \\
\text { Impact }\end{array}$ & $\begin{array}{l}\text { Instrumentation } \\
\text { Cost Impact } \\
\end{array}$ & $\begin{array}{l}\text { Total Cost } \\
\text { Impact } \\
\end{array}$ \\
\hline $\begin{array}{l}\text { Fue I Casks } \\
\text { ( } \$ 20 \text { Base Time Cost) }\end{array}$ & 2 & $\$ 12.51$ & $\$ 1.80$ & $\$ 14.31$ \\
\hline $\begin{array}{l}\text { Al] 0thers } \\
\text { ( } \$ 20 \text { Base Time Cost) }\end{array}$ & 2 & $\$ 0.09$ & $\$ 0.02$ & $\$ 0.11$ \\
\hline $\begin{array}{l}\text { Fue } 1 \text { Casks } \\
\text { ( } \$ 27 \text { Base Time Cost) }\end{array}$ & 2 & $\$ 16.68$ & $\$ 1.80$ & $\$ 18.48$ \\
\hline $\begin{array}{l}\text { A11 Others } \\
\text { ( } \$ 27 \text { Base Time Cost) }\end{array}$ & 2 & $\$ 0.12$ & $\$ 0.02$ & $\$ 0.14$ \\
\hline $\begin{array}{l}\text { Fuel Casks } \\
\text { ( } \$ 35 \text { Base Time Cost) }\end{array}$ & 2 & $\$ 22.24$ & $\$ 1.80$ & $\$ 24.04$ \\
\hline $\begin{array}{l}\text { All 0thers } \\
\text { ( } \$ 35 \text { Base Time Cost) }\end{array}$ & 2 & $\$ 0.16$ & $\$ 0.02$ & $\$ 0.18$ \\
\hline
\end{tabular}

Alpha

$\begin{array}{llccr}\begin{array}{c}\text { Fue } 1 \text { Casks } \\ (\$ 20 \text { Base Time Cost) }\end{array} & 1 & \$ 59.77 & \$ 27.21 & \$ 86.98 \\ \begin{array}{l}\text { A11 0thers } \\ (\$ 20 \text { Base Time Cost) }\end{array} & 1 \text { or } 2 & \begin{array}{c}\$ 0.43 \\ \$ 0.72\end{array} & \begin{array}{l}\$ 0.33 \\ \$ 0.04\end{array} & \$ 0.76 \\ \begin{array}{l}\text { Fue } 1 \text { Casks } \\ (\$ 27 \text { Base Time Cost) }\end{array} & 1 & \$ 83.40 & \$ 27.21 & \$ 110.61 \\ \text { A11 Others } & 1 & \$ 0.60 & \$ 0.33 & \$ 0.93 \\ (\$ 27 \text { Base Time Cost) } & & & & \\ \text { Fue } 1 \text { Casks } & 1 & \$ 107.03 & \$ 27.21 & \$ 134.24 \\ (\$ 35 \text { Base Time Cost) } & & & \$ 0.33 & \\ \text { A11 Others } & 1 & \$ 0.77 & \end{array}$


TABLE 4.2-4. Least Cost per Container for Reaching Levels 100 Times Below Current Limits

Least Cost to Atta in Levels 100 Times Be low Current Limits (1980 Dollars)

\begin{tabular}{|c|c|c|c|c|}
\hline Beta-Gamina & $\begin{array}{c}\text { Least Cost } \\
\text { Scenario } \\
\text { Number } \\
\end{array}$ & $\begin{array}{l}\text { Monitoring } \\
\text { Time Cost } \\
\text { Impact } \\
\end{array}$ & $\begin{array}{l}\text { Instrumentation } \\
\text { Cost Impact } \\
\end{array}$ & $\begin{array}{l}\text { Total cost } \\
\text { Impact } \\
\end{array}$ \\
\hline $\begin{array}{l}\text { Fue } 1 \text { Casks } \\
(\$ 20 \text { Base Time Cost) }\end{array}$ & 1 & $\$ 88.96$ & $\$ 27.21$ & $\$ 116.17$ \\
\hline $\begin{array}{l}\text { A1] Others } \\
(\$ 20 \text { Base Time } \cos t)\end{array}$ & 1 & $\$ 0.64$ & $\$ 0.33$ & $\$ 0.97$ \\
\hline $\begin{array}{l}\text { Fue } 1 \text { Casks } \\
(\$ 27 \text { Base Time Cost) }\end{array}$ & 1 & $\$ 120.96$ & $\$ 27.21$ & $\$ 148.14$ \\
\hline $\begin{array}{l}\text { A1) Others } \\
\text { (\$27 Base Time Cost) }\end{array}$ & 1 & $\$ 0.87$ & $\$ 0.33$ & $\$ 1.20$ \\
\hline $\begin{array}{l}\text { Fue T Casks } \\
(\$ 35 \text { Base Time Cost })\end{array}$ & 1 & $\$ 157.07$ & $\$ 27.21$ & $\$ 184.28$ \\
\hline $\begin{array}{l}\text { A1l Others } \\
(\$ 35 \text { Base Time Cost })\end{array}$ & 1 & $\$ 1.13$ & $\$ 0.33$ & $\$ 1.46$ \\
\hline \multicolumn{5}{|l|}{ Alpha } \\
\hline $\begin{array}{l}\text { Fue } 1 \text { Casks } \\
(\$ 20 \text { Base Time Cost }\rangle\end{array}$ & 1 & $\$ 804.81$ & $\$ 27.21$ & $\$ 832.02$ \\
\hline $\begin{array}{l}\text { Al1 0thers } \\
(\$ 20 \text { Base Time Cost })\end{array}$ & 1 & $\$ 5.79$ & $\$ 0.33$ & $\$ 6.12$ \\
\hline $\begin{array}{l}\text { Fue } 1 \text { Casks } \\
\text { ( } \$ 27 \text { Base Time Cost) }\end{array}$ & 1 & $\$ 1099.49$ & $\$ 27.21$ & $\$ 1126.70$ \\
\hline $\begin{array}{l}\text { Al1 Others } \\
(\$ 27 \text { Base Time Cost })\end{array}$ & 1 & $\$ 7.91$ & $\$ 0.33$ & $\$ 8.24$ \\
\hline $\begin{array}{l}\text { Fue } 1 \text { Casks } \\
\text { ( } \$ 35 \text { Base Time Cost) }\end{array}$ & 1 & $\$ 1427.53$ & $\$ 27.21$ & $\$ 1454.74$ \\
\hline $\begin{array}{l}\text { All others } \\
(\$ 35 \text { Base Time Cost) }\end{array}$ & 1 & $\$ 10.27$ & $\$ 0.33$ & $\$ 10.60$ \\
\hline
\end{tabular}


greater than current DOT limits (Los Alamos 1978). Another study in Illinois (I1lino is Department of Public Health 1980) found no detectable surface contamination on 51 containers wiped and a study in South Carolina discovered no excessive contamination on 80 radiopharmaceutical containers (South Carolina 1978). The results of other studies (South Carolina 1980; Carter et al. 1980), pointed to the same conclusion that the incidence of contamination in excess of current limits is very low. Two of the industrial representatives contacted cited the frequency of decontamination for radiopharmaceuticals and industrial use shipments at their facilities at about 1 in 15 million containers.

In addition, the procedures for dealing with contamination in excess of the current limits are relatively simple for many of the types of containers being examined in this study. If excess contamination is found on radiopharmaceuticals or on most industrial use shipments, the normal procedure would be to open the container, examine its contents for leaks and, if this examination were satisfactory, repackage the material. The direct costs of such procedures, in terms of labor and materials are expected to be quite low (for example, the material cost of replacing a large radiopharmaceutical container is only about $\$ 1.15$ ).

Thus, because the frequency of decontamination is so low and because the costs of decontamination are also low, the total direct cost impacts for decontamination of radiopharmaceuticals and industrial source shipments limits is assumed, for purposes of this study, to be negligible.

\subsubsection{Spent Fuel Casks}

For spent fue 1 casks and waste drums, the containers (i.e., the casks and the drums) appear to have a significant economic value. Thus, when contamination is found on a container, it would be decontaminated rather than replaced. For spent fuel casks in particular, decontamination is a normal procedure and a major cost element of cask shipping (Anderson et al. 1978). Designs which facilitate easier decontamination are given significant weight in cask design (Rhoads 1977). 
The materials costs for decontaminating metal containers are quite low. Normally, simple alcohol or soap solutions are used to wash down the casks or drums. Thus, the primary cost of decontamination is labor time.

Our industrial contacts indicated that the costs per hour for decontamination of spent fuel casks and waste drums are normally the same as the costs per hour for monitoring such containers. The same workers are usually involved in both operations and radiation monitoring is performed after each decontamination to insure that the decontamination was successful in getting the container surface contamination below required levels. Thus, $\$ 30$ an hour was chosen as an average fully burdened cost per hour for decontamination.

To determine the decontamination cost impacts of reduced limits for removable contamination, the frequency of decontamination under the current regulations must first be estimated. Once this is done, an additional problem is to determine the reduction in contamination level each time a decontamination is performed (i.e., the decontamination factor).

Industrial records on spent fuel cask decontamination are used as a bas is for estimating decontamination factors and costs. These records included approximately 77 observations on spent fuel cask shipments made between March, 1979 and August, 1980. Contamination levels were recorded for every area of the cask and transporting vehicle by taking smear samples after decontamination. These records are quite extensive, and an average of 89 smears were normaliy taken from the surface of the cask and transporting trailer after initial decontamination. Note that all of the numbers and records discussed in the remainder of this decontamination analys is are for beta-gamma radiation oniy. The records of alpha radiation indicated that the levels found on spent fuel casks are very low or nondetectable. 
No records are available on contamination levels prior to decontamination, since all casks are routinely decontaminated once before the contamination levels are measured. In addition, a policy that requires removable contamination levels that are 10 times below the current nonexciusive use levels is often used in the industry. This is done to insure that any "sweating" of the cask surface during transport will not result in surface contamination levels that are in excess of current DOT limits.

To reach surface contamination levels equal to or less than the current DOT limits, initial decontamination of the cask usually requires about two hours of labor time for two men. This leads to a base cask decontamination cost of $\$ 120$ per cask, assuming an hourly fully burdened cost of $\$ 30$. Only 4 of the 77 casks were found to have contamination levels in excess of the current limits after one decontamination. This means that only about 5 percent of the casks would require further decontamination under current regulations after the initial washdown. Further decontamination is estimated to require two men and 30 minutes of effort, for an additional cost of $\$ 30$. Thus, assuming that one tota 1 washdown would always be necessary, the average cost of reaching the current levels is calculated as follows for nonexclusive use shipments:

$$
\begin{gathered}
\left(\begin{array}{l}
\text { Base Cask } \\
\text { Decontami- } \\
\text { nation Cost }
\end{array}\right)+\left(\begin{array}{l}
\text { Frequency } \\
\text { of Further } \\
\text { Decontami- } \\
\text { nation }
\end{array}\right) \cdot\left(\begin{array}{l}
\text { Cost of } \\
\text { Further } \\
\text { Decontami- } \\
\text { nation }
\end{array}\right)=\left(\begin{array}{l}
\text { Total } \\
\text { Costs to } \\
\text { reach } \\
\text { current } \\
\text { limits }
\end{array}\right) \\
\text { or: } \$ 120+(0.05) \cdot(\$ 30)=\$ 121.50
\end{gathered}
$$

To reach surface contamination levels 10 times below current DOT limits, spent fue 1 casks require another spot decontamination of certain areas about 90 percent of the time. Because only certain areas require a second decontamination, the time required averages about 30 minutes for two men, leading to an additional cost of $\$ 30$ per cask. Infrequentiy 
(about 12 percent of the time), a third spot decontamination is required, which also requires about 30 minutes for two men and another cost of $\$ 30$. Thus, in reaching levels 10 times below the current limits the average cost of decontamination per cask is calculated as follows:

$$
\begin{aligned}
\left(\begin{array}{l}
\text { Base Case } \\
\text { Decontami- } \\
\text { nation Cost }
\end{array}\right)+\left(\begin{array}{l}
\text { Frequency of } \\
\text { Second Decon- } \\
\text { tamination }
\end{array}\right) \cdot\left(\begin{array}{l}
\text { Cost of } \\
\text { Second } \\
\text { Decontam- } \\
\text { ination }
\end{array}\right)+\left(\begin{array}{l}
\text { Frequency } \\
\text { of Third } \\
\text { Decontami- } \\
\text { nat ion }
\end{array}\right) \cdot\left(\begin{array}{l}
\text { Cost of } \\
\text { Th ird } \\
\text { Decontam- } \\
\text { inat ion }
\end{array}\right) \\
=\left(\begin{array}{l}
\text { Total Costs } \\
\text { to Reach 10 } \\
\text { Times Less } \\
\text { Than Current } \\
\text { Limits }
\end{array}\right) \\
\text { or: } \$ 120+(0.90) \cdot(\$ 30)+(0.12) \cdot(\$ 30)=\$ 151 \text { per cask }
\end{aligned}
$$

The average contamination levels after one, two and three decontaminations are illustrated in Figures 4.3-1 and 4.3-2. A bar graph representation is used since the post-decontamination levels shown are for averaged cases. The dotted lines connecting the costs on these figures are added to show the trend of the data, and they should not be used to estimate costs to achieve intermediate levels of decontamination, since the costs of reaching levels 100 times below the current limits are calculated on the basis of extrapolated decontamination factors.

Note that Figures 4.3-1 and 4.3-2 present information for two separate cases: the case where two decontaminations are required to get below required levels and the case where three decontaminations are required. This is done since combining the two cases gives the distorted picture that contamination levels after three decontaminations are greater than contamination levels after two decontaminations. This occurs because those cases where three decontaminations are necessary appear to be cases where the contamination was not easily reduced, rather than cases 


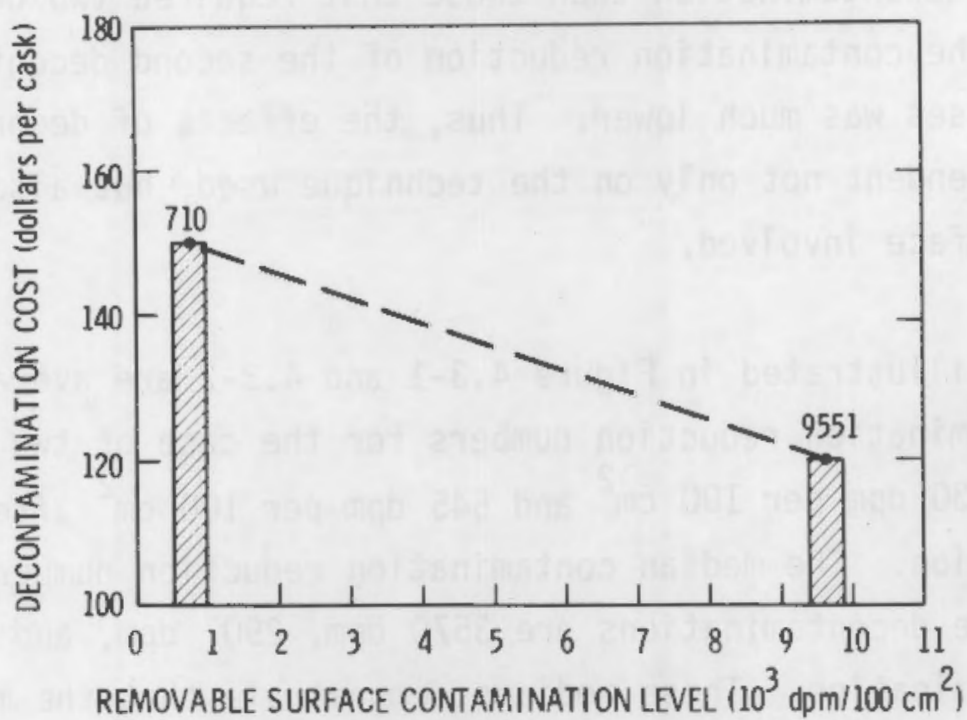

FIGURE 4.3-1 Cost-Contamination Relationship for Spent Fuel Casks with Two Decontaminations

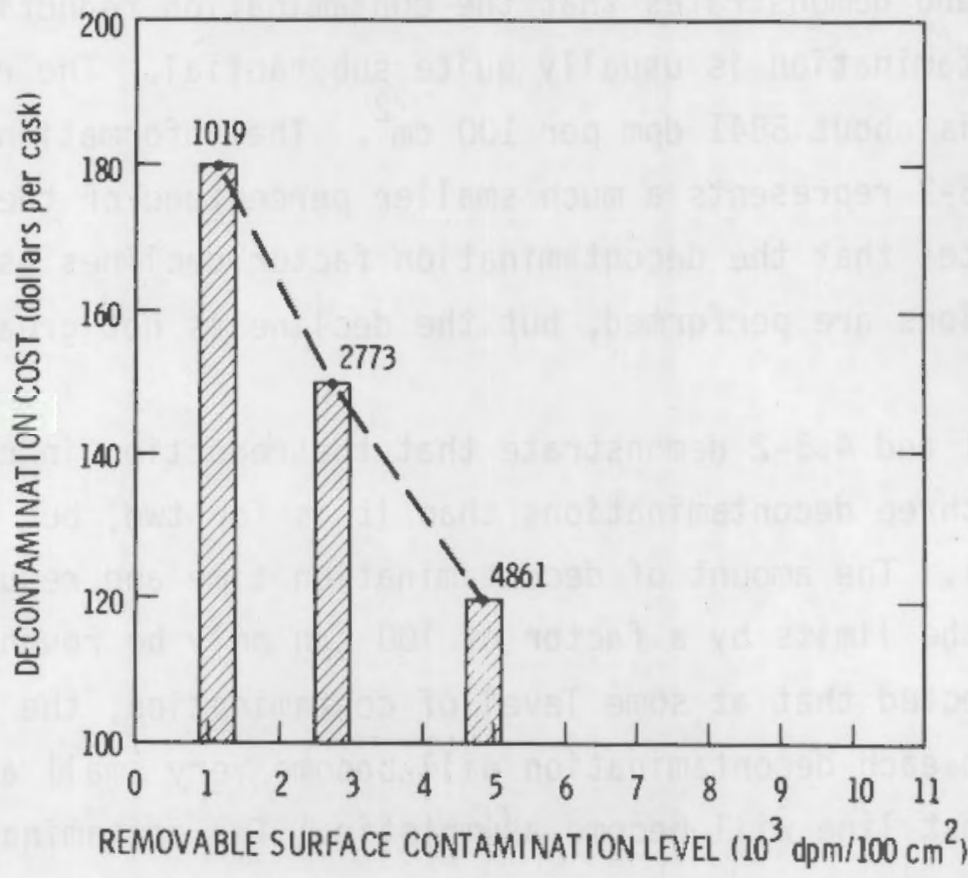

FIGURE 4.3-2 Cost-Contamination Relationship for Spent Fuel Casks with Three Decontaminations 
where contamination was abnormally high. Those cases that required three decontaminations actually had a lower contamination level after the initial decontamination than those that required two decontaminations, but the contamination reduction of the second decontamination for these cases was much lower. Thus, the effects of decontamination are very dependent not only on the technique used, but also on the specific surface involved.

The numbers illustrated in Figure 4.3-1 and 4.3-2 are averages. The median contamination reduction numbers for the case of two decontaminations are $3030 \mathrm{dpm}$ per $100 \mathrm{~cm}^{2}$ and $545 \mathrm{dpm}$ per $100 \mathrm{~cm}^{2}$ after each decontamination. The median contamination reduction numbers for the case of three decontaminations are $3570 \mathrm{dpm}, 2907 \mathrm{dpm}$, and $930 \mathrm{dpm}$ after each decontamination. These medians demonstrate that the majority of shipments are below the average numbers illustrated in Figures 4.3-1 and 4.3-2 for each decontamination.

The cases illustrated in Figure 4.3-1 represent a large majority of the total cases and demonstrates that the contamination reduction from a second decontamination is usually quite substantial. The reduction in these cases is about $8841 \mathrm{dpm}$ per $100 \mathrm{~cm}^{2}$. The information presented in Figure 4.3-2 represents a much smaller percentage of the total cases and illustrates that the decontamination factor declines as more decontaminations are performed, but the decline is not great.

Figures 4.3-1 and 4.3-2 demonstrate that the reduction in contamination is less for three decontaminations than it is for two, but the difference is small. The amount of decontamination time and resulting costs of reducing the limits by a factor of 100 can only be roughly estimated, as it is expected that at some level of contamination, the reduction achieved from each decontamination will become very small and the contamination-cost line will become asymptotic. The contamination level 
where this will occur is unknown, but the information presented in Figures 4.3-1 and 4.3-2 demonstrates that it is not happening at the levels reported in our available data.

From the curves in Figures 4.3-1 and 4.3-2 it appears that one extra decontamination would be enough to get the surface levels on the casks to $220 \mathrm{dpm}$ per $100 \mathrm{~cm}^{2}$. The cost of this extra decontamination is assumed to be $\$ 30$ and, $\$ 30$ was added to the cost of decontamination for the 90 percent requiring two decontaminations and the 12 percent requiring three. Thus, the costs of reaching levels 100 times below the current levels is approximated as follows:

$$
\begin{aligned}
\left(\begin{array}{l}
\text { Base Case } \\
\text { Decontami- } \\
\text { nation Cost }
\end{array}\right)+\left(\begin{array}{l}
\text { Frequency } \\
\text { of Second } \\
\text { Decontami- } \\
\text { nation }
\end{array}\right) \cdot\left(\begin{array}{l}
\text { Cost of } \\
\text { Second } \\
\text { Decontam- } \\
\text { ination }
\end{array}\right)+\left(\begin{array}{l}
\text { Frequency } \\
\text { of Th ird } \\
\text { Decontami- } \\
\text { nation }
\end{array}\right) \cdot\left(\begin{array}{l}
\text { Cost of } \\
\text { Th ird } \\
\text { Decontam- } \\
\text { ination }
\end{array}\right) \\
= \\
\\
=\left(\begin{array}{l}
\text { Total Costs } \\
\text { To Reach 100 } \\
\text { Times Less } \\
\text { Than Current } \\
\text { Limits }
\end{array}\right) \\
\$ 120+(0.90) \cdot(\$ 60)+(0.12) \cdot(\$ 60)=\$ 181
\end{aligned}
$$

This cost estimate is developed from the information collected from industry contacts in 1980 dollars. According to this information about 90 percent of all shipments must be decontaminated twice to reach levels 10 times below the current allowable levels and 12 percent of total shipments must be decontaminated three times. From the information presented in Figures $4.3-1$ and 4.3-2 an extra decontamination would be all that is necessary to reach levels 100 times below the current limits.

\subsubsection{Low-Level Waste Drums}

The data on decontamination of waste drums is not as readily available as that for spent fuel casks. Only one waste shipper provided 
information on decontamination costs under current conditions. They estimate that it requires two laborers about two hours for an initial decontamination of a shipment of waste drums and the average shipment is about 70 drums. In addition to the initial decontamination, about 5 percent of the drums require further decontamination to get below current limits and this usually requires about 10 minutes per drum for two men. Thus, using a fully burdened charge of $\$ 30$ per hour the costs of decontaminating waste drums under the current levels is calculated as follows:

$$
\begin{gathered}
\left.\left[\begin{array}{l}
\text { Base Case } \\
\text { Decontam- } \\
\text { inat ion } \\
\text { Cost for } \\
\text { all drums }
\end{array}\right)+\left(\begin{array}{l}
\text { Frequency } \\
\text { of Second } \\
\text { Decontami- } \\
\text { nat ion }
\end{array}\right) \cdot\left(\begin{array}{l}
\text { Number } \\
\text { of } \\
\text { Drums }
\end{array}\right) \cdot\left(\begin{array}{l}
\text { Cost } \\
\text { per } \\
\text { Drum }
\end{array}\right)\right]=\begin{array}{l}
\text { Total Costs to } \\
\text { Reach Current } \\
\text { Limits }
\end{array} \\
\text { Number of Drums } \frac{\$ 120+(0.05) \cdot(70) \cdot(\$ 10)}{70}=\$ 2.21 \text { per drum }
\end{gathered}
$$

Since that no decontamination factors are available for waste drums, the costs of decontaminating to levels lower than the current limits can only be roughly estimated by extrapolating from the information on spent fuel casks. For spent fuel casks, the costs increased by 25 percent for levels 10 times below the current limits and 49 percent for levels 100 times below the current limits. Extrapolating these percentages to drums results in a decontamination cost of $\$ 2.76$ per drum at 10 times below the current limits and $\$ 3.29$ per drum at 100 times below the current limits.

\subsection{Total Direct Cost Impacts of Reducing the Limits for Removable Contamination}

The total direct cost impacts per container of reducing the limits for removable surface contamination are summarized in Table 4.4-1 for a monitoring base cost of $\$ 27$ per hour and decontamination time cost of 
TABLE 4.4-1. Total Direct Cost Impacts per Container for Monitoring, Instrumentation, and Decontamination of Each Container Category(a)

Total Direct Costs To Attain Levels 10 Times Below Current Limits (1980 Dollars)

\begin{tabular}{|c|c|c|c|c|}
\hline $\begin{array}{l}\text { Type of } \\
\text { Package } \\
\end{array}$ & $\begin{array}{l}\text { Monitoring } \\
\text { Cost }\end{array}$ & $\begin{array}{l}\text { Instrumentation } \\
\text { Cost }\end{array}$ & $\begin{array}{c}\text { Decontamination } \\
\text { Cost }\end{array}$ & $\begin{array}{l}\text { Total } \\
\text { Cost } \\
\end{array}$ \\
\hline $\begin{array}{l}\text { Radiophar- } \\
\text { maceuticals }\end{array}$ & so.12 & $\$ 0.02$ & -- & \$0.14 \\
\hline $\begin{array}{l}\text { Industrial } \\
\text { Source } \\
\text { Shipments }\end{array}$ & $\$ 0.12$ & $\$ 0.02$ & -- & $\$ 0.14$ \\
\hline $\begin{array}{l}\text { Waste } \\
\text { Shipments }\end{array}$ & $\$ 0.12$ & $\$ 0.02$ & $\$ 0.54$ & $\$ 0.68$ \\
\hline Fuel Casks & $\$ 16.68$ & $\$ 1.80$ & $\$ 29.50$ & $\$ 47.98$ \\
\hline \multicolumn{5}{|c|}{ Alpha Radiation } \\
\hline $\begin{array}{l}\text { Radiophar- } \\
\text { maceuticals }\end{array}$ & $\$ 0.60$ & $\$ 0.33$ & -- & $\$ 0.93$ \\
\hline $\begin{array}{l}\text { Industrial } \\
\text { Source } \\
\text { Shipments }\end{array}$ & $\$ 0.60$ & $\$ 0.33$ & - & $\$ 0.93$ \\
\hline $\begin{array}{l}\text { Waste } \\
\text { Shipments }\end{array}$ & $\$ 0.60$ & $\$ 0.33$ & -- & $\$ 0.93$ \\
\hline Fuel Casks & $\$ 83.40$ & $\$ 27.21$ & -- & $\$ 110.61$ \\
\hline
\end{tabular}

Total Direct Costs to Attain Levels 100 Times Below current Limits (1980 Collars)

Beta-Gamma Radiation

\begin{tabular}{|c|c|c|c|c|}
\hline $\begin{array}{l}\text { Radiophar- } \\
\text { maceuticals }\end{array}$ & \$o. 87 & $\$ 0.33$ & $\cdots$ & $\$ 1.20$ \\
\hline $\begin{array}{l}\text { Industrial } \\
\text { Source } \\
\text { Shipments }\end{array}$ & 50.87 & $\$ 0.33$ & -- & $\$ 1.20$ \\
\hline $\begin{array}{l}\text { Waste } \\
\text { Shipments }\end{array}$ & $\$ 0.87$ & $\$ 0.33$ & $\$ 1.06$ & $\$ 2.26$ \\
\hline Fuel Casks & $\$ 120.93$ & $\$ 27.21$ & $\$ 59.50$ & $\$ 207.64$ \\
\hline \multicolumn{5}{|c|}{ Alpha Radiation } \\
\hline $\begin{array}{l}\text { Radiophar- } \\
\text { maceuticals }\end{array}$ & $\$ 7.91$ & $\$ 0.33$ & $\cdots$ & $\$ 8.24$ \\
\hline $\begin{array}{l}\text { Industrial } \\
\text { Source } \\
\text { Shipments }\end{array}$ & $\$ 7.91$ & $\$ 0.33$ & -- & $\$ 8.24$ \\
\hline $\begin{array}{l}\text { Waste } \\
\text { Shipments }\end{array}$ & $\$ 7.91$ & $\$ 0.33$ & $\cdots$ & $\$ 8.24$ \\
\hline Fue 1 Casks & $\$ 1099.49$ & $\$ 27.21$ & -- & $\$ 1126.70$ \\
\hline
\end{tabular}

(a) Based on monitoring costs of $\$ 27$ per hour per worker and decontamination costs of $\$ 30$ per hour per worker. 
$\$ 30$ per hour. Note that these estimates assume that a firm would persue a least-cost policy in relation to monitoring for reduced limits of contamination.

From the information presented in Table 4.4-1 it can be seen that the cost of verifying radiation levels below the current limits would be the largest single cost element in most cases. The total costs of modifying the current limits for alpha are greater than that for beta-gamma primarily because the current limits for alpha are 10 times below those for beta-gamma. Lowering these limits further would make detection increasingly difficult and raise monitoring time costs substantially.

The data presented in Table 4.4-1 represent the direct costs of reducing removable contamination limits on a per container basis. Additional costs would be incurred in the areas of vehicle monitoring and decontamination and the indirect costs of reduced surface contamination limits. These cost elements are discussed in the next sections.

\subsection{Vehicle Contamination}

The monitoring cost impacts of vehicle contamination at levels 10 and 100 times below current limits should be expected to be the same as that for containers on a per smear basis. However, the number of smears taken from a vehicle appears to be more variable than for containers since the vehicles have a larger surface area. To calculate the total impact on vehicle monitoring costs of lowered surface contamination limits, the number of smears taken per vehicle must be calculated or assumed.

Industrial shippers contacted indicated that the number of smears taken from a transporting vehicle depends on the type of container being transported. For radiopharmaceutical and industrial source shipments, the number of smears taken from the transporting vehicle is relatively small. One shipper of radiopharmaceuticals and industrial use shipments stated that they did not routinely monitor vehicle contamination. 
The number of smears taken from vehicles transporting spent fuel casks and industrial use shipments is appreciably higher. One shipper normally takes 28 smears from an incoming spent fuel cask transporting vehicle and 36 smears on an outgoing trailer. In addition, 30 smears are assumed to be taken at the other end of the fuel cask vehicle's trip. At one low-level waste site 11 smears are routinely taken from the inside and outside of a vehicle transporting waste shipments. Thus, by using the numbers from Tables 4.2-3 and 4.2-4 and assuming that 5 smears would be taken per transporting vehicle for radiopharmaceutical and industrial source shipments, 11 smears at each end for waste shipments, and 94 smears taken per vehicle for spent fuel casks, the monitoring cost impacts per shipment (not per container) are calculated. Adding monitoring and instrumentation costs as listed in Tables 4.2-3 and 4.2-4 for a $\$ 27$ base time cost and multiplying by the above number of smears yields total cost impacts for vehicle monitoring for all types of shipments except spent fuel casks. For spent fuel casks, the numbers listed in Tables 4.2-3 and 4.2-4 should be divided by 139 (the number of smears taken on a cask) and then multiplied by 94 . Estimated vehicle monitoring cost impacts are presented in Table 4.5-1.

The frequency of vehicle contamination in excess of current limits also depends on the type of container being transported. The frequency for radiopharmaceutical and industrial use shipments is very low. One shipper reported that in the last 10 years only three instances of vehicle contamination in excess of the current limits have been discovered.

The frequency of vehicle contamination levels above current limits is higher for spent fuel casks and waste shipments. About 6 percent of these trailers are currently reported by industry records to be in excess of current limits. Assuming that one decontamination would reduce the surface contamination levels below current limits, the decontamination costs (assuming labor costs of $\$ 30$ per hour per worker and 30 minutes per trailer for 2 workers) are: 
TABLE 4.5-1. Total Estimated Impacts on the Cost of Vehicle Monitoring per Shipment for Reduced Surface

Contamination Limit(a)

\begin{tabular}{|c|c|c|c|c|}
\hline Beta-Ganma & $\begin{array}{l}\text { Radiophar- } \\
\text { macuticals }\end{array}$ & $\begin{array}{l}\text { Industrial } \\
\text { Use } \\
\text { Shipments } \\
\end{array}$ & $\begin{array}{l}\text { Waste } \\
\text { Shipments }\end{array}$ & $\begin{array}{l}\text { Fue } 1 \\
\text { Casks } \\
\end{array}$ \\
\hline $\begin{array}{l}\text { Levels } 10 \text { Times Below } \\
\text { Current Allowable Limits }\end{array}$ & $\$ 0.70$ & $\$ 0.70$ & $\$ 3.08$ & $\$ 12.50$ \\
\hline $\begin{array}{l}\text { Levels } 100 \text { Times Below } \\
\text { Current Allowable Limits }\end{array}$ & $\$ 6.00$ & $\$ 6.00$ & $\$ 26.40$ & $\$ 100.18$ \\
\hline Alpha & & & & \\
\hline $\begin{array}{l}\text { Levels } 10 \text { Times Below } \\
\text { Current Allowable Limits }\end{array}$ & $\$ 4.65$ & $\$ 4.65$ & $\$ 20.46$ & $\$ 74.80$ \\
\hline $\begin{array}{l}\text { Levels } 100 \text { Times Below } \\
\text { Current A1lowable Limits }\end{array}$ & $\$ 41.20$ & $\$ 41.20$ & $\$ 181.28$ & $\$ 761.94$ \\
\hline
\end{tabular}

(a) Based on 1980 dollars.

$$
\begin{gathered}
\left(\begin{array}{l}
\text { Decontami- } \\
\text { nation Costs }
\end{array}\right)\left(\begin{array}{l}
\text { Frequency } \\
\text { of Decon- } \\
\text { tamination }
\end{array}\right)=\left(\begin{array}{l}
\text { Total Costs } \\
\text { per Shipment } \\
\text { to Reach } \\
\text { Current Limits }
\end{array}\right) \\
\text { or: }(\$ 30) \cdot(0.06)=\$ 1.80 \text { per shipment }
\end{gathered}
$$

The frequency of vehicle trailer contamination from spent fuel casks in excess of 10 times below current limits was reported in records obtained from industry to be 88 percent. Because detailed records are available on spent fuel cask trailer vehicle contamination, the decontamination costs for these vehicles under reduced limits could be estimated in the same manner as for the casks. It is estimated that it requires about 30 minutes for two people to decontaminate a cask hauling vehicle. Thus, at a cost of $\$ 30$ per hour, an 88 percent frequency of occurrence 
for one decontamination, and a 12 percent frequency of occurrence for a second decontamination, the decontamination costs of reaching levels 10 times below the current limits are calculated as follows:

$$
\begin{gathered}
\left(\begin{array}{l}
\text { Decontam- } \\
\text { ination } \\
\text { Costs }
\end{array}\right) \cdot\left(\begin{array}{l}
\text { Frequency } \\
\text { of First } \\
\text { Decontami- } \\
\text { nation }
\end{array}\right)+\left(\begin{array}{l}
\text { Decontam- } \\
\text { ination } \\
\text { Costs }
\end{array}\right) \cdot\left(\begin{array}{l}
\text { Frequency } \\
\text { of Second } \\
\text { Decontam- } \\
\text { ination }
\end{array}\right)=\left(\begin{array}{l}
\text { Total Costs } \\
\text { To Reach 10 } \\
\text { Times Less } \\
\text { Than Current } \\
\text { Limits } \\
\text { (Trailers) }
\end{array}\right) \\
\text { or: }(\$ 30) \cdot(0.88)+(\$ 30) \cdot(0.12)=\$ 30 \text { per shipment }
\end{gathered}
$$

The decontamination costs at levels 100 times below current limits can be extrapolated from records of contamination levels in the same manner as was performed for spent fuel casks. The cost-contamination relationships for cask transporting trailers are illustrated in Figures 4.5-1 and 4.5-2. Again, a bar graph representation is used in these figures for the contamination levels. The dotted lines connecting the points on these figures are added to show the trend of the data; and they should not be used to estimate costs to achieve intermediate levels of decontamination. Figure $4.5-1$, which represents the vast majority of cases, illustrates that one decontamination is normally enough to obtain removable surface contamination levels that are quite low. The median contamination level on trailers for this case was $475 \mathrm{dpm}$ per $100 \mathrm{~cm}^{2}$ with one decontamination, indicating that the majority of shipments had even lower radiation levels than the $640 \mathrm{dpm}$ average number.

Figure 4.5-2 demonstrates that removal of contamination becomes more difficult with each decontamination. The median contamination for this case after the second decontamination was $550 \mathrm{dpm}$. The generally low contamination levels after decontamination illustrate that levels of 100 times below current limits would probably be achievable with one extra decontamination. Thus, the average decontamination costs at these levels for vehicles hauling spent fuel casks are approximately $\$ 60$. 


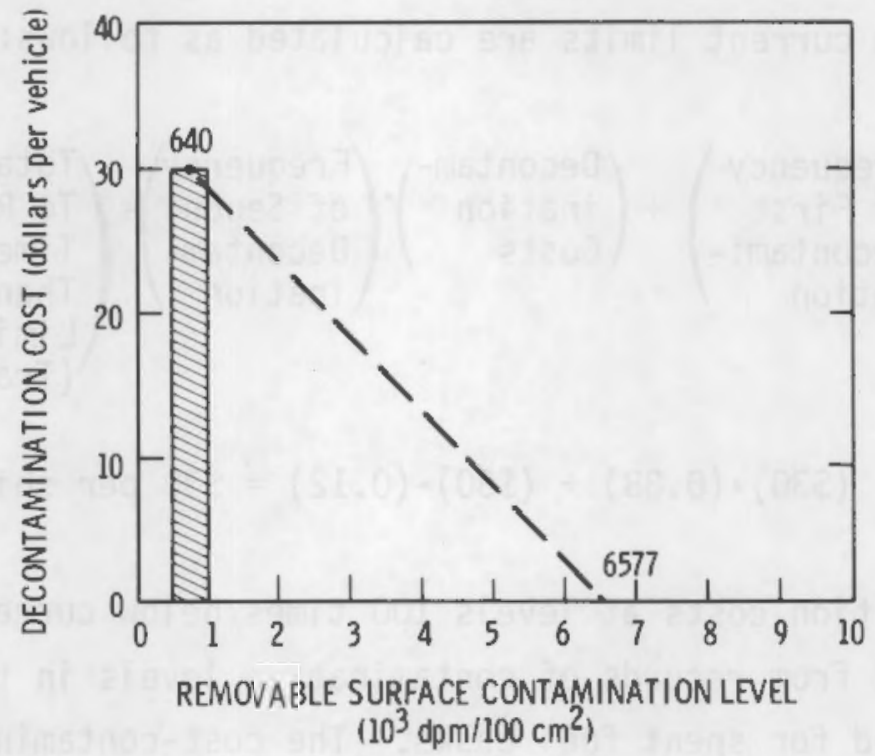

FIGURE 4.5-1 Cost-Contamination Relationship for Vehicles with One Decontamination

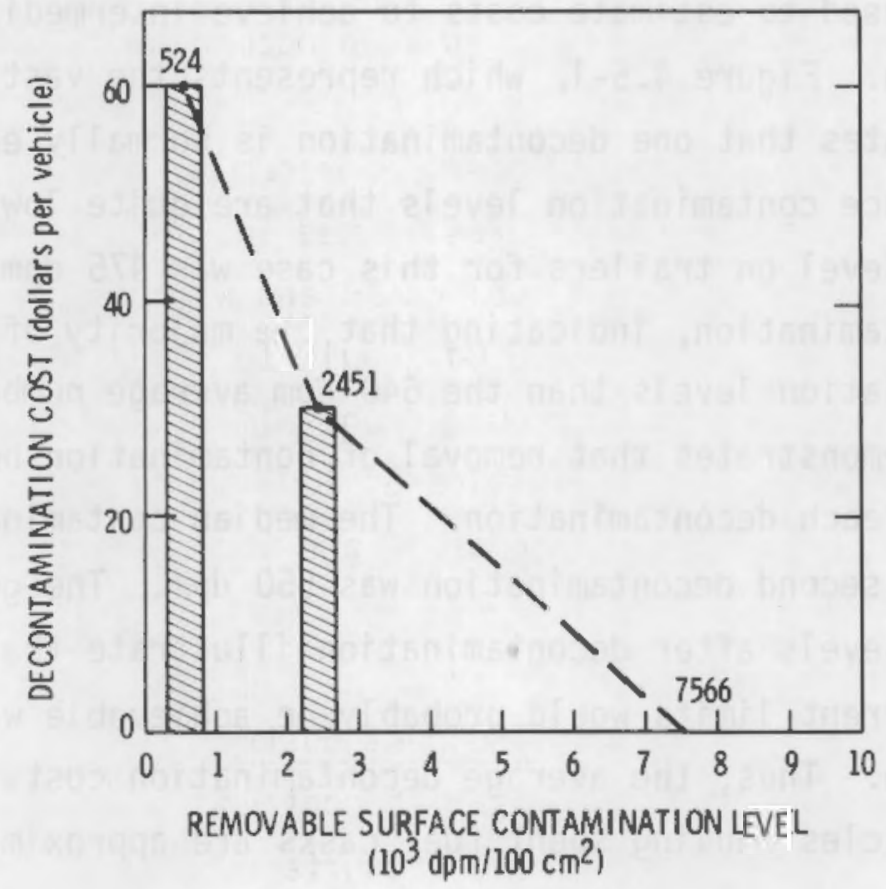

FIGURE 4.5-2 Cost Contamination Relationship for Vehicles with Two Decontaminations 
Several waste sites have encountered instances of vehicle contamination on vehicles hauling waste shipments. The cause of part of the problem with waste shipments is that wooden truckbeds, which can absorb contamination, are often used. Continuous hauling of shipments can cause a buildup of contamination in the wooden truckbed, causing contamination levels to exceed current limits at some point.

The costs of decontamination for vehicles hauling waste shipments are difficult to assess. Our contact stated that the time spent decontaminating a vehicle under the current limits may vary from a few minutes up to about 40 hours. This occurs because decontamination may require simple cleaning of a localized area or complete replacement of the truckbed. The time required to decontaminate depends on how much contamination has been absorbed into the vehicle surfaces.

The decontamination cost impacts from reducing current limits are difficult to predict, but they are probably not substantial, because lower limits would simply mean that decontamination would have to be performed before significant contamination buildup occurred.

Thus, the total impacts per shipment of reducing surface contamination limits are estimated in the figures listed in Table 4.5-1 except for beta-gamma radiation on spent fuel casks and waste shipments. For spent fuel casks, an extra cost of $\$ 28.00$ should be added for beta-gamma decontamination at 10 times below current limits and $\$ 58.20$ should be added for beta-gamma decontamination at 100 times below limits. For waste shipments, an extra charge of $\$ 1$ and $\$ 5$ would probably be adequate.

\subsection{Comments from Industry on Indirect Costs}

Almost every industrial representative contacted felt that the indirect costs of reduced limits for removable surface contamination would be higher than the direct costs. These indirect costs are difficult or impossible to quantify but they can be discussed in qualitative terms. 
The principle indirect cost, according to the sources contacted, is delays in production and distribution schedules caused by increased monitoring and decontamination time. These delays can be particularly crucial for radiopharmaceutical, because many radioactive isotopes have short half-lifes, causing their economic value to be based partially on how fast they are delivered from producer to customer. Thus, if every container required additional monitoring time, the loss in the economic value of the container contents caused by these delays could be substantial.

Another indirect cost caused by delay is increased transit costs. Most radioactive shipments are contracted to a specialized transit firm for delivery. The lost time incurred by these transit firms because of longer waits for radiation monitoring and decontamination work would have to be paid for.

A change from portable field detection instruments to more sophisticated detection instrumentation would involve additional monitoring costs besides the increased capital costs already referred to. Using these instruments to monitor samples would increase total monitoring costs because of the extra time necessary to transport smears to the laboratory facilities from the sampling area where they were taken. In addition, the costs of building new facilities to house the instrumentation could be significant.

If a container or vehicle is found to be in noncompliance with required contamination levels, the indirect costs of dealing with the problem can be substantial. One estimate of the indirect costs resulting from one container being found in noncompliance was $\$ 7000$, while the direct costs of decontaminating the container were estimated to be only $\$ 360$, meaning that indirect costs were over 19 times as great as direct cost. These indirect costs were primarily composed of the costs of site visits, report preparation, meetings with regulatory agencies and other 
administrative costs associated with providing information to regulatory agencies on the problem and how it was being corrected. An additional cost was the impounding of the hauling vehicle until it could be verified that the contamination problem had been corrected.

\subsection{Economic Cost Analysis Surmary}

The direct economic cost of reducing removable surface contamination Timits were divided into three categories for analysis in this chapter:

1) monitoring time costs, 2) instrumentation capital costs, and 3) decontamination costs. All direct cost estimates were made on the basis of constant 1980 dollars, information obtained from industrial representatives, and from theoretical cost modeling.

Based on a least-cost analys is of the 5 scenarios defined in Section 4.1, the monitoring-cost impacts of verifying compliance for levels 10 times below current limits were found to vary (depending on the cost of monitoring time) between $\$ 14.31$ and $\$ 24.04$ per cask for beta-gama monitoring of fuel casks and between $\$ 0.11$ and $\$ 0.18$ per container for other types of container. The costs for monitoring at levels 100 times below current limits were found to vary between $\$ 11.17$ and $\$ 184.28$ per spent fuel cask and $\$ 0.97$ and $\$ 1.46$ per container, for a 11 other types of containers.

The costs of monitoring alpha contamination levels for these reduced limits would be substantially higher, primarily because current limits for alpha are 10 times below those for beta-ganma. At 10 times below current limits for alpha, the estimated cost impacts are between $\$ 86.98$ and $\$ 134.24$ for spent fue] casks and between $\$ 40.76$ and $\$ 1.10$ per container for all other types of containers. At 100 times below current limits, these impacts increase to between $\$ 832.02$ and $\$ 1454.74$ per spent fue 1 cask and between $\$ 6.12$ and $\$ 10.60$ for a 11 other types of containers. 
The costs of decontaminating spent fuel casks and waste drums were analyzed. Based on the information obtained, decontamination costs for radiopharmaceutical and industrial-use shipments were assumed to be negligible. Decontamination costs for spent fuel casks were a significant cost component. Detailed records of contamination levels after decontamination were used to estimate the costs of decontamination if the current limits were reduced. The decontamination cost impacts of attaining levels 10 and 100 times below current limits were estimated to be $\$ 29.50$ and $\$ 59.50$ additional cost per spent fuel cask.

Information on the decontamination of waste drums was limited, but costs under current limits were estimated to be $\$ 2.21$ per drum. The decontamination records for fuel casks were used to extrapolate decontamination costs impacts on waste shipments for lower limits. These additional costs were estimated to be $\$ 0.54$ per drum at 10 times below current limits and $\$ 1.06$ per drum at 100 times below current limits.

Decontamination costs were added to monitoring costs to determine the total cost impacts of reducing removable surface contamination limits. When the cost impacts for beta-gamma and alpha contamination are summed and a base monitoring cost of $\$ 27$ per hour is assumed, the total cost impacts resulting from levels 10 times below current 1 imits are $\$ 1.07$ per container for radiopharmaceutical and industrial source shipments, $\$ 1.61$ per drum for waste shipments, and $\$ 158.59$ per cask for spent fuel casks. The total cost impacts at 100 times below current limits are $\$ 9.44$ per container for radiopharmaceuticals and industrial use shipments, $\$ 10.50$ per drum for low-level waste shipments, and $\$ 1334.34$ per cask for spent fuel casks. The largest cost element in these totals is the cost of alpha radiation monitoring. 
The effects of reduced limits on vehicle monitoring and decontamination costs were also estimated. At $\$ 30$ per hour for monitoring and decontamination, the total cost impact estimates at 10 times below current limits would be $\$ 5.35$ per shipment for radiopharmaceuticals and industrial use shipments, $\$ 24.54$ per shipment for waste shipments and $\$ 115.30$ per shipment for spent fuel casks. At 100 times below current limits, the cost estimates are $\$ 47.20$ per shipment for radiopharmaceuticals and industrial use shipments, $\$ 212.68$ per shipment for waste shipments and $\$ 920.32$ per shipment for spent fuel casks.

All of the industrial representatives contacted believed that the indirect costs of reduced contamination limits would probably exceed the direct costs. Some of the indirect costs would include delays in production and distribution schedules, increased transit costs because of longer waits for monitoring and decontamination, and increased administrative costs because of additional regulatory actions. 


\section{REFERENCES}

Anderson, R. J., J. B. Maier, M. Young and P. F. Highberger. 1978. Topical Report on the Operational Assessment of the Transnuclear TN-8/TN-9 Spent Fuel Cask. Allied-General Nuclear Services, Barnwe1?, South Carolina.

Bush, D., and R. C. Handa1. 1971. "Difficulties in Measuring the Maximum Permissible Levels of Surface Contamination for Radionuclides that Decay Primarily by Electron Capture." Health Physics. 21:651-655.

Carter, M. W., J. T. Gasper and B. Kahn. 1979. Transportation of Radioactive Material in Georgia. Office of Interdisciplinary Programs, Georgia Institute of Technology, Atlanta, Georgia.

Clark, R. L. 1975. Consideration on the Applicability of "As Low As Reasonably Achievable" Analys is to the Regulations of Radioactive Materials Transport. Office of Radiation Programs, U.S. Environmental Protection Agency, Washington, D.C.

Dickenson, H. W., P. M. Lantz and C. F. Holoway. 1980. Progress Report on Monitoring for Compliance with Decommissioning Criteria. Appendix A, ORNL/HASRD-78, Prepared for the NRC by 0ak Ridge Nationa 1 Laboratory, Oak Ridge, Tennessee. (Available in the NRC Public Document Room for inspection and copying for a fee.)

Iles, W. J., P. H. Purgess and D. F. White. 1977. Measurement of Activity of Surfaces Contaminated by Beta-Emitting Nucides and Electron Capture NucTides. NRPB-R60, National Radiation Protection Board, Harwe 11, England.

Klarman, H. E. 1973. "Application of Cost-Benefit Analys is to Health System Technology." Technology and Health Care Systems in the $1980^{\prime} \mathrm{s}$. M. F. Collen, Ed., DHEH Pub. (ASM) 73-3016, USPGPO.

Los Alamos Scientific Laboratory. 197B. Summary Report of the State Surveillance Program on the Transportation of Radioactive Materials. NUREG-0393, report prepared for the NRC by the LoS ATamos Scientific Laboratory, Los Alamos, New Mexico.*

Nichols, C. E. 1978. "Radiological Surveys of Radioactive Shipment, Are They Adequate " In Proceedings of the Fifth International Symposium on Packaging and Transportation of Radioactive Materials. pp. 537-539, Las Vegas, Nevada.

Price, w. J. 1964. Nuclear Radiation Detection - Second Edition. McGraw Hill Publishers, pp. 59-62, New York, New York. 
Rhoads, R. E. 1977. An Overview of Transportation in the Nuclear Fuel Cycle. BNWL-2066, Pacif ic Northwest Laboratory, Richland, Washington.

Sommers, J. F. 1975. "Sensitivity of G-M and Ion Chamber Beta-Ganma Survey Instruments." Health Physics. 28:755-761.

State of Illinois, Department of Public Health. 1980. Transportation of Radioactive Material in I11inois. NUREG/CR-0756, prepared for the NRC by the Division of Radiological Health of the State ofIllino is, Springfjeld, IIlinois. **

State of South Carolina. 1978. Transportation of Radioactive Material in South Carolina. NUREG/CR-0266, report prepared for the NRC by the South Carolina Bureau of Radiological Health, Department of Health and Environmental Control, Columbia, South Carolina.*

State of South Carolina. 1980. Transportation of Low-Leve T Radioactive Waste into South Carolina. NUREGTCR-1434, report prepared for the NRC by the South Carolina Bureau of Radiological Health, Department of

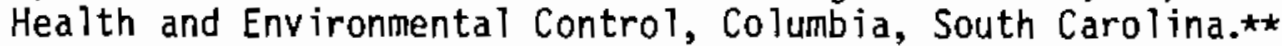

U.S. Code of Federal Regulations. 1980. Title 49, Part 173.389(f), "Radioactive Materials; Definitions." Government Printing office, Washington, D.C.

U.S. Code of Federal Regulations. 1980. Tit le 49, Part 173.397(a), "Contamination Control." Government Printing Office, Washington, D.C.

*Avaitable for purchase from the National Technical Information Service, Springfield, VA 22161.

**Available for purchase from the NRC/GPO Sales Program, U.S. Nuclear Regulatory Comrnission, Washington, DC 20555, and/or the National Technical Information Service. 



\section{CONTAMINATION FREQUENCY DISTRIBUTIONS}

The purpose of this chapter is to quantify the present levels of removable surface contamination associated with the shipment of radioactive materials. To accomplish this purpose, field trips were required to collect information from industries representing each category of transportation container considered in this study. Information was collected during these trips from both industry shipping records and from actual measurements of smears taken from container surfaces. Both aipha and beta-gamma data were collected and used to develop contamination frequency distributions that relate the number of smears to the observed or reported contamination level. This chapter contains sections that discuss the instrumentation, procedures, and results for the four categories of radioactive shipments: radiopharmaceuticals, industrial sources, nuclear fuel cycle materials, and low-level radioactive waste.

\subsection{Instrumentation}

The radiation detection instruments used to determine the activity on the smear samples collected for this project were selected based on several criteria. First, in order to quantify the amount of radiation detected over a given amount of time it was necessary to use a scaler instead of a rate meter. A scaler records the activity as a given number of counts per total time while a rate meter only gives the instantaneous activity which fluctuates over time. A second criterion was that the active area of the alpha detector and the beta-gama detector be similar in size so the same smear could be counted on both detectors. Finally, it was necessary to select semiportable instruments that could be transported between sites.

A detection system that fulfulled these requirements was the Eberline smear counting system consisting of two model MS-2 miniscalers and two model RD-13 scintillation detectors. One detector contained an alphatype scintillation crystal and the other contained a beta-type 
scintillation crystal. Both detectors had an active detector diameter of $4.3 \mathrm{~cm}$, thereby, allowing for standardization of smear size and geometry. This enabled the operator to analyze both alpha and beta-ganma radiation using the same smear sample.

The MS-2 miniscalers used were single channel pulse height analyzers. The six decade scaler allowed the sample to be counted for a set length of time. Automatic timing could be used for specific count times between 0.1 and 50 minutes. The threshold setting on both miniscalers was 500 volts. No window was set on either miniscaler, thereby allowing a full range of alpha and beta energies to be detected. The high voltage for the alpha detector was set at 450 volts, and for the beta-ganma detector it was set at 500 volts.

The instruments were initially calibrated with eight different sources. The counting efficiencies that were determined are given in Table 5.1-1. A ${ }^{137} \mathrm{Cs}\left(2.16 \times 10^{-3} \mu \mathrm{C} i\right)$ source manufactured by Westinghouse and a ${ }^{230} \mathrm{Th}\left(1.96 \times 10^{-2} \mu \mathrm{C} i\right)$ source from Eberline were used to verify that the instruments were operating at the efficiencies previously determined.

\subsection{Procedures}

The smear samples were taken using whatman No. 5 filter paper which has a diameter of $4.25 \mathrm{~cm}$. The area smeared was approximately $300 \mathrm{~cm}^{2}$ which is equivalent to that prescribed by the Department of Transportation regulations in $49 \mathrm{CFR}$ 173. The smears were numbered consecutively and placed separately in correspondingly numbered envelopes inmediately after each smear was taken.

The activity on each smear was counted for 5 minutes which allowed the detection of $0.22 \mathrm{dpm} / \mathrm{cm}^{2}$ aipha and $2.2 \mathrm{dpm} / \mathrm{cm}^{2}$ beta-gamma (from a smear covering 300 square centimeters of surface) with a relative counting counting error of less than $10 \%$ (based on calculations made 
TABLE 5.1-1 Calibration of the Eberline MS-2 Miniscaler with the Eberline Alpha RD-13 and Beta RD-13 External Probes Probes

$\begin{aligned} & \text { Calibration of Eberline MS-2 Miniscaler and Eberline } \\ & \text { Alpha RD-13 External Detector }\end{aligned}$
$\begin{array}{rlr}\text { Nuclide } & \text { Energy (MeV) } & \text { Counting Efficiency } \% \\ 239 \mathrm{Pu} & 5.15 & 41.7 \% \\ 230_{\text {Th }} & 4.68 & 42.3 \%\end{array}$

Calibration of TberTine MS-2 Miniscaler and Eberline Beta RD-13 Externa] Detector

$\begin{array}{ccc}\text { Nuclide } & \text { Energy (MeV) } & \text { Counting Efficiency } \% \\ & 0.155 & 10 . \% \\ { }^{14} \mathrm{C} & 0.290 & 24 . \% \\ { }^{99} \mathrm{TC} & 0.714 & 44.5 \% \\ { }^{36} \mathrm{Cl} & 1.17 & 36 . \% \\ { }^{210} \mathrm{Bi} & 2.32 & 16 . \% \\ { }^{234} \mathrm{~Pa} & 0.56-2.27 & 54 . \% \\ { }^{90} \mathrm{Sr}-\mathrm{Y} & & \end{array}$

using Equation 4.8 from Chapter 4). The current maximum permissible leve 1 for removable radioactive contamination is $2200 \mathrm{dpm} / \mathrm{cm}^{2}$ betaganma and $220 \mathrm{dpm} / \mathrm{cm}^{2}$ alpha for natural or depleted uranium and natural thorium. Therefore, a factor of 1000 exists between detection level of the instruments (with less than $10 \%$ relative counting error) and the current contamination limits. For all other beta-gamma emitting radionuclides the maximum permissible level is $220 \mathrm{dpm} / \mathrm{cm}^{2}$ and for all other alpha enitting radionuclides it is $22 \mathrm{dpm} / \mathrm{cm}^{2}$. Both measurements are a factor of 100 above the detection level of the system (with $10 \%$ relative counting error). Background counts were calculated by averaging over a 20 minute period prior to each use of the instruments. 
The gross counts per minute were converted into net $\mathrm{dpm} / \mathrm{cm}^{2}$ using the efficiency of ${ }^{90} \mathrm{Sr}-{ }^{90} \mathrm{Y}$ for beta-gamma radiation and ${ }^{239} \mathrm{Pu}$ for alpha radiation since the actual isotopes present on the smear were unknown.

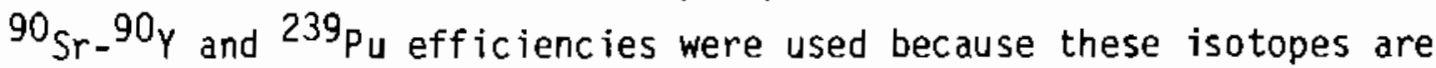
considered "worst case isotopes" due to their relative toxicity and radiobiological damage potential. The counting efficiency of the beta detector is higher for ${ }^{90} \mathrm{Sr}-{ }^{90} \mathrm{Y}$ than for other isotopes and thus the reading was a lower estimate of the amount of beta-ganma contamination on the smear. Since the energies of most alpha emitting isotopes are within a narrow range, the measurements made were good estimates of the amount of alpha contamination present on the smear independent of the actual isotope present.

A limited gamma-spectra analysis using a Ge-Li detector was conducted on the low-level waste smear which contained a detectable amount of contamination $\left(1.23 \mathrm{dpm} / \mathrm{cm}^{2}\right)$. The results showed very small amounts of ${ }^{137} \mathrm{Cs},{ }^{58} \mathrm{Co},{ }^{54} \mathrm{Mn}$ and ${ }^{60} \mathrm{Co}$ barely measurable above background. No further spectra analyses were conducted since only one smear sample contained activity significant enough to analyze.

\subsection{Radiopharmaceuticals}

Removable surface contamination frequency distribution data for removable surface contamination on 142 radiopharmaceutical shipping containers is listed in Table 5.3-1. Containers from three different sites were examined. These containers consisted of cardboard boxes and metal cans. All measurements were below the statistical detection limit of the instrumentation for a $10 \%$ relative counting error, and most betagarma data points were at least three orders of magnitude below the current DOT limits. The level of a ipha contamination was also we 11 below the current DOT limits. An additional 110 data points were obtained from seven sites during a related study being conducted for the NRC by Reynolds Electric and Engineering Co. Inc. (REECO), on radiation exposures to workers during transportation of radiopharmaceuticals. These data points are included at the end of Table 5.3-1 with REECO listed in place of the sample number. 
TABLE 5.3-1 Frequency Distribution Data for Radiopharmaceuticals

\begin{tabular}{|c|c|c|c|c|}
\hline $\begin{array}{l}\text { Samp le } \\
\text { Number }\end{array}$ & $\begin{array}{l}\text { Package } \\
\text { Type } \\
\end{array}$ & $\begin{array}{l}\text { Labeled } \\
\text { Contents }\end{array}$ & $\begin{array}{l}\text { Beta-Ganma } \\
\left(\mathrm{dpm} / \mathrm{cm}^{2}\right)\end{array}$ & $\begin{array}{l}\text { A lpha } \\
\left(\mathrm{dpm} / \mathrm{cm}^{2}\right)\end{array}$ \\
\hline 120 & Cardboard & $125_{\mathrm{I}}$ & Bkgrd (a) & Bkgrd $(b)$ \\
\hline 121 & " & -- & $"$ & $"$ \\
\hline 127 & " & 99Mо & .14 & " \\
\hline 128 & $"$ & " & .09 & $"$ \\
\hline 129 & $n$ & ${ }^{169} \mathrm{Yb}(25 \mathrm{mC} i)$ & .19 & $"$ \\
\hline 130 & $"$ & " & .44 & $"$ \\
\hline 131 & $"$ & $"$ & .15 & $"$ \\
\hline 132 & $"$ & $"$ & Bkgrd & $"$ \\
\hline 133 & $"$ & $"$ & $n$ & $"$ \\
\hline 134 & $"$ & $"$ & $"$ & $"$ \\
\hline 135 & $"$ & $"$ & $"$ & $"$ \\
\hline 136 & $"$ & $"$ & $"$ & $"$ \\
\hline 137 & $"$ & " & $"$ & $"$ \\
\hline 138 & $"$ & ${ }^{125} \mathrm{I}(31 \mathrm{mC} \mathrm{i})$ & $"$ & $"$ \\
\hline 139 & " & $"(.065 C i)$ & .02 & $"$ \\
\hline 140 & $"$ & $"(.168 \mathrm{C} i)$ & Bkgrd & $"$ \\
\hline 141 & $"$ & $"(.305 \mathrm{Ci})$ & 11 & $"$ \\
\hline 159 & $"$ & ${ }^{85} \mathrm{Sr}(.5 \mu \mathrm{C} i)$ & $"$ & .01 \\
\hline \multirow[t]{4}{*}{160} & $"$ & ${ }^{85} \operatorname{Sr}(2 \mu E i)$ & $"$ & $"$ \\
\hline & & ${ }^{141} \mathrm{Ce}(2 \mu \mathrm{Ci})$ & $"$ & $"$ \\
\hline & & ${ }^{125} \mathrm{I}(\mathrm{\mu} \mathrm{Ci})$ & $"$ & $"$ \\
\hline & & ${ }^{46} \mathrm{Sc}(1 \mu C i)$ & & \\
\hline 161 & $"$ & -- & .02 & Bkgrd \\
\hline 162 & $"$ &.- & .02 & 1 \\
\hline 163 & $"$ & $\ldots$ & .03 & 11 \\
\hline 164 & $"$ &.- & .02 & $"$ \\
\hline 165 & $"$ & -- & .02 & $"$ \\
\hline 166 & $"$ & $\cdots$ & .01 & " \\
\hline
\end{tabular}


TABLE 5.3-1 (Cont'd)

\begin{tabular}{|c|c|c|c|c|}
\hline $\begin{array}{l}\text { Sample } \\
\text { Number }\end{array}$ & $\begin{array}{c}\text { Package } \\
\text { Type } \\
\end{array}$ & $\begin{array}{l}\text { Labeled } \\
\text { Contents }\end{array}$ & $\begin{array}{l}\text { Beta-Ganmma } \\
\left(\mathrm{dpm} / \mathrm{cm}^{2}\right)\end{array}$ & $\begin{array}{l}\text { Alpha } \\
\left(\mathrm{dpm} / \mathrm{cm}^{2}\right)\end{array}$ \\
\hline 167 & Cardboard &.- & Bkgrd & $"$ \\
\hline 168 & $"$ & ${ }^{131_{I}}$ & .01 & $"$ \\
\hline 169 & $"$ & ${ }^{125} \mathrm{I}(1.54 \mathrm{mC})$ & Bkgrd & $"$ \\
\hline 170 & " & ${ }^{125} \mathrm{I}(.1 \mathrm{mC} i)$ & .02 & $"$ \\
\hline 171 & $"$ & " & Bkgrd & $"$ \\
\hline 172 & $"$ & ${ }^{125} \mathrm{I}(.02 \mathrm{mC} i)$ & .01 & $"$ \\
\hline 173 & $"$ & -- & .01 & $"$ \\
\hline 174 & $"$ & $\begin{array}{l}{ }^{32} P(\mu C i) \\
131_{I(2 \mu C i)}\end{array}$ & Bkgrd & $"$ \\
\hline 175 & $"$ & ${ }^{125} \mathrm{I}(.02 \mathrm{mC} \mathrm{i})$ & $"$ & $"$ \\
\hline 176 & $"$ & ${ }^{125} \mathrm{I}(.04 \mathrm{mCi})$ & $"$ & $"$ \\
\hline 177 & $"$ & ${ }^{125} \mathrm{I}(.02 \mathrm{mC} i)$ & .02 & .01 \\
\hline 178 & $"$ & ${ }^{125} \mathrm{I}(10 \mathrm{mC} i)$ & Bkgrd & Bkgrd \\
\hline 179 & $"$ & ${ }^{125} \mathrm{I}(5 \mathrm{mC} \mathrm{i})$ & " & " \\
\hline 180 & $"$ & $125 \mathrm{I}(2 \mathrm{~m} C \mathrm{i})$ & .03 & $"$ \\
\hline 181 & $"$ & $125 \mathrm{I}(20 \mathrm{mC} \mathrm{i})$ & Bkgrd & $"$ \\
\hline 182 & $"$ & ${ }^{131}$ I $(5 \mathrm{mC} i)$ & .01 & $"$ \\
\hline 183 & $"$ & ${ }^{14} c(1 \mathrm{mC})$ & .06 & $"$ \\
\hline 184 & $"$ & ${ }^{14} c(50 m C i)$ & Bkgrd & $"$ \\
\hline 185 & " & ${ }^{3} \mathrm{H}(10 \mathrm{mCi})$ & " & $"$ \\
\hline 186 & $"$ & ${ }^{125} \mathrm{I}(.02 \mathrm{mCi})$ & .06 & $"$ \\
\hline 187 & $"$ & ${ }^{3} \mathrm{H}(5 \mathrm{mC} i)$ & Bkgrd & " \\
\hline 188 & $"$ & ${ }^{125} \mathrm{I}(10 \mathrm{mC} i)$ & " & $"$ \\
\hline 189 & $"$ & 125 I & $"$ & $"$ \\
\hline 190 & $"$ & $"$ & .06 & $"$ \\
\hline 191 & $"$ & $"$ & .01 & $"$ \\
\hline 192 & $"$ & ${ }^{14} \mathrm{C}$ & .02 & $"$ \\
\hline 193 & $"$ & $"$ & Bkgrd & $"$ \\
\hline 194 & $"$ & $125_{I}$ & .01 & $"$ \\
\hline 195 & $"$ & $"$ & .01 & $"$ \\
\hline 196 & $"$ & ${ }^{14} \mathrm{C}(.05 \mathrm{mC} i)$ & Bkgrd & $"$ \\
\hline & & 5.6 & & \\
\hline
\end{tabular}


TABLE 5.3-1 (Cont'd)

\begin{tabular}{|c|c|c|c|c|}
\hline $\begin{array}{l}\text { Sample } \\
\text { Number }\end{array}$ & $\begin{array}{c}\text { Pack age } \\
\text { Type }\end{array}$ & $\begin{array}{l}\text { Labeled } \\
\text { Contents }\end{array}$ & $\begin{array}{l}\text { Beta-Gastma } \\
\left(\mathrm{dpm} / \mathrm{cm}^{2}\right)\end{array}$ & $\begin{array}{c}\text { Alpha } \\
\left(\mathrm{dpm} / \mathrm{cm}^{2}\right) \\
\end{array}$ \\
\hline 197 & $"$ & ${ }^{3} \mathrm{H}(\operatorname{lmC} i)$ & $"$ & $"$ \\
\hline 198 & $"$ & ${ }^{125} \mathrm{I}$ & .01 & .01 \\
\hline $\begin{array}{l}199 \\
200\end{array}$ & " & $\begin{array}{l}57 \mathrm{Co}(.01 \mathrm{mC} \mathrm{i}) \\
1255_{\mathrm{I}}\end{array}$ & $\begin{array}{l}\text { Bkgrd } \\
.01\end{array}$ & $\begin{array}{c}\text { Bkgrd } \\
"\end{array}$ \\
\hline 201 & $"$ & ${ }^{14} \mathrm{C}(.05 \mathrm{mCi})$ & .03 & $"$ \\
\hline 202 & $"$ & ${ }^{51} \mathrm{Cr}(2 \mathrm{mC} i)$ & Bkgrd & $"$ \\
\hline 203 & $"$ & ${ }^{125} \mathrm{I}$ & .01 & $"$ \\
\hline 204 & $"$ & ${ }^{125} \mathrm{I}(1 \mathrm{mC} i)$ & Bkgrd & $"$ \\
\hline 205 & $"$ & $125 \mathrm{I}$ & " & $"$ \\
\hline 206 & $"$ & $125 \mathrm{I}(.005 \mathrm{mC} i)$ & $"$ & 4 \\
\hline 207 & $"$ & ${ }^{125}{ }_{I}$ & .01 & $"$ \\
\hline 208 & $"$ & $"$ & .01 & $"$ \\
\hline 209 & $"$ & $"$ & Bkgrd & $"$ \\
\hline 210 & $"$ & $"$ & $"$ & $"$ \\
\hline 211 & $"$ & $"$ & $"$ & $"$ \\
\hline 212 & $"$ & " & $"$ & $"$ \\
\hline 213 & " & ${ }^{51} \mathrm{Cr}(5 \mathrm{mCi})$ & .01 & $"$ \\
\hline 214 & $"$ & $\begin{array}{l}{ }^{14} \mathrm{C}(6 \mathrm{mC} \mathrm{i}), \\
{ }^{3} \mathrm{H}(255 \mathrm{mC} i)\end{array}$ & Bkgrd & $"$ \\
\hline 215 & $"$ & ${ }^{125} \mathrm{I}(.275 \mathrm{mC} \mathrm{C})$ & Bkgrd & Bkgrd \\
\hline 216 & $"$ & ${ }^{125} \mathrm{I}(80 \mathrm{mC} \mathrm{i})$ & $"$ & $"$ \\
\hline 217 & $"$ & ${ }^{125} \mathrm{I}(160 \mathrm{mC} \mathrm{i})$ & $"$ " & $"$ \\
\hline 218 & $n$ & ${ }^{125} \mathrm{I}(180 \mathrm{mC} \mathrm{i})$ & $"$ & $"$ \\
\hline 219 & $"$ & $\begin{array}{l}{ }^{133_{\mathrm{Ba}}},{ }^{14} \mathrm{C} \\
241_{\mathrm{Am}}\end{array}$ & $"$ & .01 \\
\hline 220 & $"$ & ${ }^{51} \mathrm{Cr}(175.11 \mathrm{mCj})$ & $"$ & Bkgrd \\
\hline 221 & Can & ${ }^{226} \mathrm{Ra}(5 \mathrm{mC} \mathrm{i})$ & $"$ & $"$ \\
\hline 222 & Cardboard & ${ }^{32} p(63.82 \mathrm{mC} i)$ & $"$ & $"$ \\
\hline 223 & $"$ & ${ }^{3} \mathrm{H}(4 \mathrm{mCi})$ & .06 & $"$ \\
\hline 224 & $"$ & $\cdots$ & Bkgrd & $"$ \\
\hline
\end{tabular}


TABLE 5.3-1 (Cont'd)

\begin{tabular}{|c|c|c|c|c|}
\hline $\begin{array}{l}\text { Sample } \\
\text { Number }\end{array}$ & $\begin{array}{l}\text { Pack age } \\
\text { Type }\end{array}$ & $\begin{array}{l}\text { Labeled } \\
\text { Contents }\end{array}$ & $\begin{array}{l}\text { Beta-Gamma } \\
\left(\mathrm{dpm} / \mathrm{cm}^{2}\right)\end{array}$ & $\begin{array}{c}\text { Alpha } \\
\left(\mathrm{dpm} / \mathrm{cm}^{2}\right)\end{array}$ \\
\hline 225 & Cardboard & ${ }^{3} \mathrm{H}(10 \mathrm{mC} i)$ & " & $"$ \\
\hline 226 & Can & ${ }^{3} \mathrm{H}(373 \mathrm{mCi})$ & $"$ & $"$ \\
\hline 227 & $"$ & ${ }^{3} \mathrm{H}(21.75 \mu \mathrm{Ci})$ & .05 & $"$ \\
\hline 228 & Cardboard & ${ }^{125} \mathrm{I}(.02 \mathrm{mC} i)$ & Bkgrd & $"$ \\
\hline 229 & " = & ${ }^{125} I$ & " & $"$ \\
\hline 230 & $"$ & $"$ & .01 & $"$ \\
\hline 231 & $"$ & " & Bkgrd & " \\
\hline 232 & $"$ & $"$ & $"$ & $"$ \\
\hline 233 & $"$ & $"$ & $"$ & $"$ \\
\hline 234 & $"$ & $"$ & .02 & $"$ \\
\hline 235 & $"$ & $"$ & .03 & $"$ \\
\hline 236 & $"$ & ${ }^{67} \mathrm{Ga}(.093 \mathrm{C} i)$ & .01 & $"$ \\
\hline 237 & $"$ & ${ }^{99} \mathrm{Mo}(1.35 \mathrm{C} i)$ & .02 & $"$ \\
\hline 238 & $"$ & ${ }^{67} \mathrm{Ga}(.046 \mathrm{C} i)$ & $"$ & $"$ \\
\hline 239 & $"$ & ${ }^{133} \mathrm{Xe}(.270 \mathrm{Ci})$ & .04 & $"$ \\
\hline 240 & $"$ & ${ }^{201} \mathrm{TT}(.058 \mathrm{C} i)$ & .01 & $"$ \\
\hline 241 & $"$ & ${ }^{57} \mathrm{Co}(2 \mathrm{mC} i)$ & Bkgrd & $"$ \\
\hline 242 & $"$ & ${ }^{137} \operatorname{Cs}(2 \mu C i)$ & .04 & $"$ \\
\hline 243 & $"$ & ${ }^{151_{S m(200 m C i}}$ & .06 & $"$ \\
\hline 244 & $"$ & ${ }^{57} \mathrm{Co}(5 \mathrm{mC} i)$ & .06 & $"$ \\
\hline 245 & $"$ & ${ }^{125} \mathrm{I}(120 \mathrm{mC} \mathrm{i})$ & .09 & $"$ \\
\hline 246 & $n$ & ${ }^{99} \mathrm{Mo}(2.7 \mathrm{Ci})$ & .02 & $"$ \\
\hline 247 & $"$ & ${ }^{99} \mathrm{Mo}(1.35 \mathrm{Ci})$ & .03 & $"$ \\
\hline 248 & $"$ & ${ }^{99} \mathrm{Mo}(2.25 \mathrm{Ci})$ & .08 & $"$ \\
\hline 249 & $"$ & ${ }^{99} \mathrm{Mo}(1.35 \mathrm{Ci})$ & .09 & " \\
\hline 250 & " & ${ }^{99} \mathrm{Mo}_{0}(2.7 \mathrm{Ci})$ & .07 & $"$ \\
\hline 251 & " & ${ }^{99} \mathrm{Mo}(1.35 \mathrm{Ci})$ & .03 & $"$ \\
\hline 252 & $"$ & ${ }^{99} \mathrm{Mo}(2.25 \mathrm{Ci})$ & .04 & $"$ \\
\hline 253 & $"$ & ${ }^{99} \mathrm{Mo}(.45 \mathrm{Ci})$ & .06 & $"$ \\
\hline 254 & $"$ & ${ }^{99} \mathrm{Mo}(.45 \mathrm{C} i)$ & .01 & $"$ \\
\hline 255 & $"$ & ${ }^{99} \mathrm{Mo}(.45 \mathrm{Ci})$ & .02 & 11 \\
\hline & & 5.8 & & \\
\hline
\end{tabular}


TABLE 5.3-1 (Cont' $d$ )

\begin{tabular}{|c|c|c|c|c|}
\hline $\begin{array}{l}\text { Sample } \\
\text { Number }\end{array}$ & $\begin{array}{c}\text { Pack age } \\
\text { Type }\end{array}$ & $\begin{array}{l}\text { Labeled } \\
\text { Contents }\end{array}$ & $\begin{array}{l}\text { Beta-Gamma } \\
\left(\mathrm{dpm} / \mathrm{cm}^{2}\right)\end{array}$ & $\begin{array}{l}\text { ATpha } \\
\left(\mathrm{dpm} / \mathrm{cm}^{2}\right)\end{array}$ \\
\hline 256 & Cardboard & ${ }^{99} \mathrm{Mo}(.9 \mathrm{Ci})$ & Bkgrd & Bkgrd \\
\hline 257 & $"$ & ${ }^{99} \mathrm{Mo}(.675 \mathrm{C} i)$ & .04 & $"$ \\
\hline 258 & $"$ & ${ }^{99} \mathrm{Mo}(.9 \mathrm{Ci})$ & .04 & $"$ \\
\hline 259 & $"$ & ${ }^{133} \mathrm{Xe}(.05 \mathrm{C} i)$ & Bkgrd & $n$ \\
\hline 260 & $"$ & ${ }^{133} \mathrm{Xe}(.040 \mathrm{C} i)$ & .06 & $"$ \\
\hline 261 & $"$ & ${ }^{133} \mathrm{Xe}(.1 \mathrm{Ci})$ & .06 & $a$ \\
\hline 262 & $"$ & ${ }^{67} \mathrm{Ga}(.009 \mathrm{Ci})$ & .07 & $"$ \\
\hline 263 & $"$ & ${ }^{67} \mathrm{Ga}(.003 \mathrm{Ci})$ & .01 & $"$ \\
\hline 264 & $"$ & ${ }^{133} \times e(.04 C i)$ & Bkgrd & $"$ \\
\hline 265 & $"$ & ${ }^{99} \mathrm{Mo}(.45 \mathrm{Ci})$ & .05 & .01 \\
\hline 266 & $"$ & " & Bkgrd & Bkgrd \\
\hline 267 & $"$ & ${ }^{99} \mathrm{Mo}(1.35 \mathrm{Ci})$ & .04 & .01 \\
\hline 268 & $"$ & " & .01 & Bkgrd \\
\hline 269 & $"$ & ${ }^{99} \mathrm{Mo}(1.35 \mathrm{C} i)$ & .02 & " \\
\hline 274 & $"$ & ${ }^{206} \mathrm{~T} 1(.002 \mathrm{C})$ & Bkgrd & $"$ \\
\hline 275 & $"$ & $"$ & " & " \\
\hline 276 & $"$ & $"$ & $"$ & $"$ \\
\hline 277 & $"$ & $"$ & $"$ & $"$ \\
\hline 278 & $"$ & $"$ & $"$ & $"$ \\
\hline 279 & $"$ & $n$ & $"$ & $n$ \\
\hline 280 & $"$ & $"$ & $"$ & $"$ \\
\hline 281 & $"$ & $"$ & $"$ & $"$ \\
\hline 282 & $"$ & ${ }^{57} \mathrm{Co}(.002 \mathrm{Ci})$ & " & $"$ \\
\hline 283 & $"$ & ${ }^{3} H(.01 C i)$ & $n$ & $"$ \\
\hline 284 & $"$ & ${ }^{35} S(.0012 C i)$ & $"$ & $"$ \\
\hline 285 & $"$ & ${ }^{35} \mathrm{~S}(.0048 \mathrm{C} i)$ & $"$ & $"$ \\
\hline 286 & $"$ & Exempt Quantity & $"$ & $"$ \\
\hline 287 & $"$ & ${ }^{35} S(.0012 C i)$ & $"$ & $"$ \\
\hline
\end{tabular}


TABLE 5.3-1 (Cont'd)

\begin{tabular}{|c|c|c|c|c|}
\hline $\begin{array}{l}\text { Sample } \\
\text { Number }\end{array}$ & $\begin{array}{l}\text { Pack age } \\
\text { Type }\end{array}$ & $\begin{array}{l}\text { Labeled } \\
\text { Contents }\end{array}$ & $\begin{array}{l}\text { Beta-Gamma } \\
\left(\mathrm{dpm} / \mathrm{cm}^{2}\right) \\
\end{array}$ & $\begin{array}{c}\text { Alpha } \\
\left(\mathrm{dpm} / \mathrm{cm}^{2}\right) \\
\end{array}$ \\
\hline $\operatorname{REECO}(\mathrm{c})$ & Cardboard & ${ }^{99} \mathrm{Mo}_{\mathrm{O}}$ & Bkgrd & Bkgrd \\
\hline 11 & " & $"$ & $1 "$ & " \\
\hline$"$ & $"$ & $\because$ & $"$ & $"$ \\
\hline$"$ & $n$ & $"$ & $"$ & $"$ \\
\hline$"$ & $"$ & $"$ & $"$ & $"$ \\
\hline$"$ & $"$ & $"$ & $"$ & $"$ \\
\hline$"$ & $"$ & $"$ & $"$ & $"$ \\
\hline$"$ & $"$ & $"$ & $"$ & $"$ \\
\hline$"$ & $"$ & 11 & $"$ & $"$ \\
\hline$"$ & $"$ & $"$ & $"$ & $"$ \\
\hline$"$ & $"$ & $"$ & $"$ & $"$ \\
\hline$"$ & $"$ & $"$ & $"$ & $"$ \\
\hline$"$ & $"$ & ॥ & $"$ & $"$ \\
\hline$"$ & $"$ & ${ }^{131} \mathrm{I}$ & $"$ & $"$ \\
\hline$"$ & $"$ & $131_{\mathrm{I}}$ & $"$ & $"$ \\
\hline$"$ & $"$ & $67_{\mathrm{Ga}}$ & $"$ & $"$ \\
\hline$"$ & $"$ & $99_{\mathrm{Mo}}$ & $"$ & $"$ \\
\hline$"$ & $"$ & $"$ & $"$ & $"$ \\
\hline$"$ & $"$ & $"$ & " & $"$ \\
\hline$"$ & $"$ & $"$ & $"$ & $"$ \\
\hline$"$ & $"$ & $"$ & $"$ & 4 \\
\hline$"$ & $"$ & $"$ & $"$ & $"$ \\
\hline$"$ & $"$ & $"$ & $"$ & $"$ \\
\hline$"$ & $"$ & $"$ & $"$ & $"$ \\
\hline$"$ & $"$ & ॥ & $"$ & $"$ \\
\hline$"$ & $"$ & ${ }^{131}$ & $"$ & $"$ \\
\hline$"$ & $"$ & $"$ & " & $"$ \\
\hline$"$ & $"$ & $"$ & $"$ & $"$ \\
\hline " & u & " & $"$ & $"$ \\
\hline
\end{tabular}


TABLE 5.3-1 (Cont'd)

\begin{tabular}{|c|c|c|c|c|}
\hline $\begin{array}{l}\text { Sample } \\
\text { Number }\end{array}$ & $\begin{array}{c}\text { Package } \\
\text { Type }\end{array}$ & $\begin{array}{l}\text { Labe led } \\
\text { Contents }\end{array}$ & $\begin{array}{l}\text { Beta-Gamma } \\
\left(\mathrm{dpm} / \mathrm{cm}^{2}\right)\end{array}$ & $\begin{array}{c}\text { Alpha } \\
\left(\mathrm{dpm} / \mathrm{cm}^{2}\right)\end{array}$ \\
\hline REECO $(\mathrm{c})$ & Cardboard & ${ }^{99} \mathrm{Mo}_{\mathrm{O}}$ & Bkgrd & Bkgrd \\
\hline " & " & " & " & $"$ \\
\hline$"$ & $"$ & $"$ & 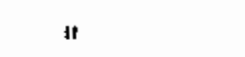 & $"$ \\
\hline$"$ & $"$ & $"$ & $"$ & $"$ \\
\hline$"$ & $"$ & $"$ & $"$ & $"$ \\
\hline$"$ & $"$ & $"$ & $"$ & $"$ \\
\hline$"$ & $"$ & $"$ & $"$ & $"$ \\
\hline$"$ & $"$ & $"$ & $"$ & $"$ \\
\hline$"$ & $"$ & " & $n$ & $"$ \\
\hline 1 & $"$ & $131_{1}$ & " & $"$ \\
\hline$"$ & $"$ & $"$ & $"$ & $"$ \\
\hline$"$ & $"$ & ${ }^{3} \mathrm{H}$ & $"$ & $"$ \\
\hline$"$ & $"$ & ${ }^{67} \mathrm{Ga}$ & $"$ & $"$ \\
\hline " & $"$ & ${ }^{133} \mathrm{Xe}$ & $"$ & $"$ \\
\hline$n$ & $"$ & ${ }^{99} \mathrm{Mo}_{\mathrm{O}}$ & $"$ & $"$ \\
\hline$"$ & $"$ & $"$ & " & $"$ \\
\hline$"$ & $"$ & $"$ & $n$ & $"$ \\
\hline 14 & $"$ & " & $"$ & $"$ \\
\hline$"$ & $"$ & ${ }^{51}{ }_{C r}$ & $"$ & $"$ \\
\hline$"$ & $"$ & $1^{11} 1_{\text {In }}$ & $"$ & $"$ \\
\hline$"$ & $"$ & n & $"$ & $"$ \\
\hline$"$ & $"$ & ${ }^{133} \times \mathrm{e}$ & $"$ & $"$ \\
\hline$"$ & $"$ & " & $"$ & $"$ \\
\hline$"$ & $"$ & " & $"$ & "t \\
\hline " & $"$ & $99_{\mathrm{MO}}$ & $"$ & " \\
\hline$"$ & $"$ & " & 4 & $"$ \\
\hline$"$ & $n$ & $"$ & $"$ & $"$ \\
\hline$"$ & $"$ & $"$ & $"$ & $"$ \\
\hline w & $w$ & $"$ & $"$ & $"$ \\
\hline$"$ & $"$ & " & $"$ & $"$ \\
\hline$"$ & $"$ & $"$ & $n$ & $"$ \\
\hline
\end{tabular}


TABLE 5.3-1 (Cont'd)

\begin{tabular}{|c|c|c|c|c|}
\hline $\begin{array}{l}\text { Sample } \\
\text { Number }\end{array}$ & $\begin{array}{c}\text { Package } \\
\text { Type }\end{array}$ & $\begin{array}{l}\text { Labeled } \\
\text { Contents }\end{array}$ & $\begin{array}{l}\text { Beta-Gamma } \\
\left(\mathrm{dpm} / \mathrm{cm}^{2}\right)\end{array}$ & $\begin{array}{l}\text { Alpha } \\
\left(\mathrm{dpm} / \mathrm{cm}^{2}\right)\end{array}$ \\
\hline $\operatorname{REECO}^{(c)}$ & Cardboard & ${ }^{99} \mathrm{MO}_{\mathrm{O}}$ & Bkgrd & Bkgrd \\
\hline " & " & $n$ & 11 & 11 \\
\hline$"$ & $n$ & $" 1$ & " & " \\
\hline " & 11 & " & $n$ & $"$ \\
\hline$"$ & 11 & $67 \mathrm{Ga}$ & " & 11 \\
\hline$"$ & $"$ & ${ }^{131}$ I & 11 & " \\
\hline 11 & " & 11 & $"$ & $n$ \\
\hline 11 & " & ${ }^{99} M_{0}$ & $"$ & "I \\
\hline$"$ & $"$ & I & II & $"$ \\
\hline 1 & " & $n$ & $"$ & 11 \\
\hline 11 & $" 1$ & $" 1$ & 11 & $"$ \\
\hline " & II & "I & i3 & 11 \\
\hline 11 & 11 & " & $"$ & $"$ \\
\hline$"$ & 11 & " & $"$ & u \\
\hline$\|$ & "1 & $"$ & " & 11 \\
\hline " & " & " & 11 & " \\
\hline$" 1$ & " & " & $"$ & $"$ \\
\hline$"$ & "1 & ${ }^{131_{I}}$ & " & $" \prime$ \\
\hline$"$ & $"$ & 1 & 11 & "t \\
\hline $1 "$ & $n$ & ${ }^{51} \mathrm{Cr}$ & 11 & $n$ \\
\hline $\mathbf{4}$ & " & ${ }^{67} \mathrm{Ga}$ & "I & " \\
\hline$"$ & $"$ & $99_{\mathrm{Mo}}$ & " & 11 \\
\hline$"$ & 11 & $n$ & 11 & $"$ \\
\hline 11 & 4 & 11 & $u$ & $"$ \\
\hline$"$ & 1 & 11 & $"$ & " \\
\hline$"$ & $"$ & $\|$ & 11 & it \\
\hline 11 & " & $"$ & " & " \\
\hline " & " & " & $" 1$ & " \\
\hline " & $"$ & " & " & " \\
\hline " & $"$ & " & $n$ & " \\
\hline 11 & " & $\|$ & " & 11 \\
\hline
\end{tabular}


TABLE 5.3-1 (Cont'd)

\begin{tabular}{|c|c|c|c|c|}
\hline $\begin{array}{l}\text { Sample } \\
\text { Number }\end{array}$ & $\begin{array}{c}\text { Package } \\
\text { Type }\end{array}$ & $\begin{array}{l}\text { Labeled } \\
\text { Contents } \\
\end{array}$ & $\begin{array}{l}\text { Beta-Gamma } \\
\left(\mathrm{dpm} / \mathrm{cm}^{2}\right)\end{array}$ & $\begin{array}{l}\text { Alpha } \\
\left(\mathrm{dpm} / \mathrm{cm}^{2}\right)\end{array}$ \\
\hline $\operatorname{REECO}^{(\mathrm{c})}$ & Cardboard & ${ }^{51} \mathrm{Cr}$ & Bkgrd & Bkgrd \\
\hline " & " & ${ }^{67} \mathrm{Ga}$ & " & $"$ \\
\hline$"$ & $"$ & ${ }^{131_{I}}$ & $"$ & $"$ \\
\hline$"$ & 11 & $131_{I}$ & " & " \\
\hline$"$ & $"$ & ${ }^{99} \mathrm{Mo}_{\mathrm{O}}$ & " & $"$ \\
\hline$"$ & $"$ & $n$ & $"$ & " \\
\hline$"$ & $"$ & $"$ & $"$ & $"$ \\
\hline$"$ & 1 & $"$ & $"$ & $n$ \\
\hline$"$ & $"$ & $"$ & $"$ & $"$ \\
\hline$"$ & $"$ & $"$ & $"$ & $"$ \\
\hline$"$ & $"$ & $"$ & $"$ & $"$ \\
\hline$"$ & $"$ & $"$ & $"$ & 11 \\
\hline$"$ & $"$ & $"$ & $"$ & $"$ \\
\hline$"$ & $"$ & " & $"$ & $"$ \\
\hline$"$ & $"$ & ${ }^{67} \mathrm{Ga}$ & $"$ & " \\
\hline$n$ & $"$ & " & $1 "$ & $"$ \\
\hline$\|$ & $"$ & ${ }^{111_{\text {In }}}$ & $"$ & $"$ \\
\hline$"$ & $"$ & ${ }^{131} 1_{I}$ & $"$ & $"$ \\
\hline$"$ & ." & $"$ & " & $"$ \\
\hline$"$ & $n$ & $"$ & $"$ & $"$ \\
\hline
\end{tabular}

(a) The average background (Bkgrd) count rate for beta-gamma measurements of radiopharmaceuticals was $122 \mathrm{cpm}$.

(b) The average background (Bkgrd) count rate for alpha measurements of radiopharmaceuticals was $1 \mathrm{cpm}$.

(c) REECO indicates data obtained from the Reynolds Electric Engineering Co. Inc. during a paraliel study for the NRC. 


\subsection{Industrial Sources}

Table 5.4-1 lists the 43 removable surface contamination data points which were obtained from industrial source shipping containers. The data was from container smears taken at three different sites. Twentynine of the data points were collected from containers just prior to shipping, while the other 14 were collected from containers being received.

Analys is of the smears from all of the containers revealed beta-ganma contamination levels that were below the amount which could be measured at the $10 \%$ counting accuracy level. In order for the highest of the measurements $\left(0.14 \mathrm{dpm} / \mathrm{cm}^{2}\right)$ to have been considered significant with a $10 \%$ relative counting error, the counting time would have to have been 50 minutes (based on calculations made using Equation 4.8 from Chapter 4). This measurement, although it was the highest recorded, was a factor of about 1500 times less than the DOT limits.

None of the smears contained alpha contamination that was detectable at the $10 \%$ relative counting error limitation set for the instruments. The smear containing the greatest amount of alpha contamination $\left(0.01 \mathrm{dpm} / \mathrm{cm}^{2}\right)$ was a factor of about 2000 times less than the current DOT limits.

\subsection{Nuclear Fuel Cycle Materials}

The amount of removable surface contamination present on nuclear fuel cycle materials shipping containers was examined for two types of nuclear fuel cycle shipments; uranium shipments $\left(U_{3} \mathrm{D}_{8}\right.$ and $\left.\mathrm{UF}_{6}\right)$, and spent fuel shipments. Differences in the data collection methods and the results require that these two types of shipments be discussed separately.

\subsubsection{Uranium Shipments}

Forty data points were collected from the surface of shipping containers at a uranium conversion plant. The types of containers examined included 55 gallon drums containing yellowcake shipped from a uranium 
TABLE 5.4-1. Frequency Distribution Data for Industria] Sources

\begin{tabular}{|c|c|c|c|c|}
\hline $\begin{array}{l}\text { Samp le } \\
\text { Number }\end{array}$ & Package Type & Labeled Contents & $\begin{array}{r}\text { Beta-Gamma } \\
\left(\mathrm{dpm} / \mathrm{cm}^{2}\right)\end{array}$ & $\begin{array}{r}\text { Alpha } \\
\left(\mathrm{dpm} / \mathrm{cm}^{2}\right) \\
\end{array}$ \\
\hline 95 & Cardboard box & ${ }^{85} \mathrm{Kr}(.1 \mathrm{Ci})$ & Bkgrd (a) & Bkgrd (b) \\
\hline 96 & " & " & .07 & .01 \\
\hline 97 & $"$ & $"$ & .09 & Bkgrd) \\
\hline 122 & $"$ & ${ }^{210} \mathrm{Po}$ & .04 & $"$ \\
\hline 123 & $"$ & 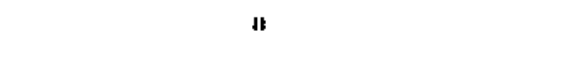 & Bkgrd & " \\
\hline 124 & $"$ & $"$ & .11 & $"$ \\
\hline 125 & $"$ & $"$ & .10 & $"$ \\
\hline 126 & $"$ & " & .14 & $"$ \\
\hline 142 & $"$ & ${ }^{210} \mathrm{Po}(.01 \mathrm{Ci})$ & Bkgrd & $"$ \\
\hline 143 & $"$ & $"$ & .01 & .01 \\
\hline 144 & $"$ & $"$ & .02 & Bkgrd \\
\hline 145 & $"$ & " & Bkgrd & .01 \\
\hline 146 & $"$ & ${ }^{210}$ Po $(.02 \mathrm{Ci})$ & $"$ & Bkgrd \\
\hline 147 & $"$ & ${ }^{210} \mathrm{Po}(.04 \mathrm{Ci})$ & .04 & " \\
\hline 148 & $"$ & ${ }^{210} \mathrm{Po}(.01 \mathrm{Ci})$ & Bkgrd & $n$ \\
\hline 149 & $"$ & ${ }^{210}$ Po $(.01 \mathrm{Ci})$ & $"$ & .01 \\
\hline 150 & $"$ & " & $"$ & Bkgrd \\
\hline 151 & $"$ & $"$ & $"$ & $"$ \\
\hline 152 & $"$ & $"$ & Bkgrd & $"$ \\
\hline 153 & $"$ & $"$ & $"$ & $"$ \\
\hline 154 & $"$ & $"$ & $"$ & .01 \\
\hline 155 & $"$ & $"$ & .03 & Bkgrd \\
\hline 156 & $"$ & $"$ & .04 & $"$ \\
\hline 157 & $"$ & 1 & .03 & $"$ \\
\hline 158 & $"$ & ${ }^{210} \mathrm{Po}(.12 \mathrm{Ci})$ & Bkgrd & $"$ \\
\hline 270 & $"$ & ${ }^{57} \mathrm{Co}(.48 \mathrm{mCi})$ & $"$ & $"$ \\
\hline 271 & $"$ & ${ }^{195} \mathrm{Au}(1.53 \mathrm{mCi})$ & $"$ & $"$ \\
\hline 272 & $"$ & ${ }^{57} \mathrm{Co}(5 \mathrm{mCi})$ & $"$ & $"$ \\
\hline 273 & $"$ & ${ }^{60} \mathrm{Co},{ }^{137} \mathrm{Cs},{ }^{57} \mathrm{Co}(5.25 \mathrm{mCi})$ & $"$ & $"$ \\
\hline
\end{tabular}


TABLE $5.4-1 . \quad$ (Cont'd)

\begin{tabular}{|c|c|c|c|c|}
\hline $\begin{array}{l}\text { Sample } \\
\text { Number }\end{array}$ & Package Type & Labeled Contents & $\begin{array}{r}\text { Beta-Gamma } \\
\left(\mathrm{dpm} / \mathrm{cm}^{2}\right)\end{array}$ & $\begin{array}{c}\text { Alpha } \\
\left(\mathrm{dpm} / \mathrm{cm}^{2}\right)\end{array}$ \\
\hline 288 & $"$ & ${ }^{32} \mathrm{p}(19 \mathrm{Ci})$ & & Bkgrd \\
\hline 289 & $"$ & ${ }^{32} p(19 \mathrm{Ci})$ & $"$ & $"$ \\
\hline 290 & $"$ & ${ }^{125} \mathrm{I}(.004 \mathrm{Ci})$ & " & $"$ \\
\hline 291 & $"$ & ${ }^{35} S(.005 C i)$ & .06 & $"$ \\
\hline 292 & $"$ & ${ }^{32} \mathrm{p}(.01 \mathrm{Ci})$ & .03 & $"$ \\
\hline 293 & $"$ & ${ }^{51} \mathrm{Cr}(.01 \mathrm{Cj})$ & .04 & $"$ \\
\hline 294 & $"$ & ${ }^{32} p(.05 \mathrm{Ci})$ & .07 & $"$ \\
\hline 295 & Cardboard box & ${ }^{32} \mathrm{p}(.01 \mathrm{Ci})$ & Bkgrd & Bkgrd \\
\hline 296 & " & ${ }^{45} \mathrm{Ca}(.001 \mathrm{Ci})$ & $"$ & $"$ \\
\hline 297 & $"$ & ${ }^{32} \mathrm{p}(.002 \mathrm{Ci})$ & .02 & $"$ \\
\hline 298 & $"$ & ${ }^{125} \mathrm{I}(.01 \mathrm{Ci})$ & .06 & $"$ \\
\hline 299 & $"$ & ${ }^{125} \mathrm{I}(.001 \mathrm{Ci})$ & Bkgrd & $"$ \\
\hline 300 & $"$ & ${ }^{125}$ I $(.001 \mathrm{Ci})$ & $"$ & $"$ \\
\hline 301 & $"$ & ${ }^{33} \mathrm{p}(.001 \mathrm{Ci})$ & $"$ & $"$ \\
\hline
\end{tabular}

(a) The average background (Bkgrd) count rate for beta-gamma measurements of industrial sources was $114 \mathrm{cpm}$.

(b) The average background (Bkgrd) count rate for alpha measurements of industrial sources was $1 \mathrm{cpm}$. 
mi11, three sizes of cylinders (2.5 tons, 10 tons and 14 tons) containing uranium hexafluoride being sent offsite, and the same cylinders returning to the plant empty. The frequency distribution data points obtained are listed in Table 5.5-1. These data points are based on a smear covering an average area of $100 \mathrm{~cm}^{2}$. All smears were detected to have beta-gamma activities less than $4.40 \mathrm{dpm} / \mathrm{cm}^{2}$ which is about a factor of 500 less than the Department of Transportation (DOT) limits.

Sixty-eight percent $(68 \%)$ of the smears tested for alpha contamination are below the $10 \%$ relative counting error limit of the instruments using a five minute count time. As the data illustrates, all of the smearable contamination measurements were below the DOT limits by about a factor of 60 .

\subsubsection{Spent Fuel Shipments}

Although spent fuel casks were not available for actual surface contamination measurement, it was possible to acquire some shipping records for the last two years from industrial records. The site data reviewed reported about 37 smear samples from incoming, loaded spent fuel casks and about 52 smears from outgoing, empty casks. Filter paper, $4.7 \mathrm{~cm}$ in diameter, was used to smear an area of $100 \mathrm{~cm}^{2}$. The smears were counted on a Beckman shielded gas flow proportional counter for 20 seconds. The efficiency of the counter was $50 \%$ for beta-gamma radiation and $33 \%$ for alpha radiation in a $2 \pi$ geometry. The background was $30 \mathrm{cpm}$ for beta-gamma and $1 \mathrm{cpm}$ for alpha.

According to calculations, the Beckman counter is able to detect betagamma radiation levels below $10 \mathrm{dpm} / \mathrm{cm}^{2}$ with a 20 second counting time and a counting error of less than $10 \%$. This is a factor of 20 below the maximum permissible level of removable beta-gama radioactive contamination. The system is able to detect alpha radiation levels of $10 \mathrm{dpm} / \mathrm{cm}^{2}$ with a 20 second counting time and a counting error of less than $10 \%$. This is about 2 times below the current permissible level for removable aTpha contamination. 
TABLE 5.5-1. Frequency Distribution Data for Nuclear Nuclear Fuel Cycle Shipments

(Yellowcake \& $\mathrm{UF}_{6}$ )

\begin{tabular}{|c|c|c|c|c|c|}
\hline $\begin{array}{l}\text { Samp le } \\
\text { Number }\end{array}$ & Package Type & Labeled & Contents & $\begin{array}{l}\text { Beta-Gamma } \\
\left(\mathrm{dpm} / \mathrm{cm}^{2}\right)\end{array}$ & $\begin{array}{l}\text { Alpha } \\
\left(\mathrm{dpm} / \mathrm{cm}^{2}\right)\end{array}$ \\
\hline 302 & 55 gallon drum & $\mathrm{U}_{3} \mathrm{O}_{8} \quad(250$ & $m(i)$ & .24 & .11 \\
\hline 303 & $"$ & h & " & .32 & .12 \\
\hline 304 & " & $"$ & $"$ & .95 & .58 \\
\hline 305 & $"$ & $"$ & $"$ & .73 & .36 \\
\hline 306 & $"$ & $"$ & $"$ & 1.02 & .52 \\
\hline 307 & $"$ & $"$ & $"$ & .11 & .08 \\
\hline 308 & $"$ & $"$ & $"$ & .76 & .40 \\
\hline 309 & $"$ & $"$ & $"$ & .44 & .34 \\
\hline 310 & $"$ & $"$ & $"$ & .13 & .13 \\
\hline 311 & $"$ & $"$ & $"$ & .54 & .59 \\
\hline 312 & $"$ & $"$ & $"$ & .18 & .08 \\
\hline 313 & $u$ & $"$ & $"$ & .98 & .88 \\
\hline 314 & $"$ & $"$ & $"$ & 4.40 & 3.25 \\
\hline 315 & $"$ & $"$ & $"$ & Bkgrd $(a)$ & .05 \\
\hline 316 & $"$ & $"$ & $"$ & .39 & .26 \\
\hline 317 & $"$ & $"$ & $"$ & .38 & .26 \\
\hline 318 & 10 ton cylinder & $\mathrm{UF}_{6}$ & empty & .24 & Bkgrd $(b)$ \\
\hline 319 & " & $"$ & $"$ & Bkgrd & .01 \\
\hline 320 & $n$ & $"$ & $"$ & $"$ & .03 \\
\hline 321 & $"$ & $"$ & $"$ & $"$ & Bkgrd \\
\hline 322 & $"$ & $"$ & " & $"$ & " \\
\hline 323 & $"$ & $"$ & " & $"$ & $"$ \\
\hline 324 & $"$ & $"$ & " & $"$ & $"$ \\
\hline 325 & $"$ & $"$ & " & .04 & $"$ \\
\hline 326 & $"$ & $"$ & " & .14 & .04 \\
\hline 327 & $"$ & $"$ & " & .03 & .01 \\
\hline 328 & " & $"$ & " & Bkgrd & Bkgrd \\
\hline 329 & $"$ & $"$ & full & .67 & .16 \\
\hline
\end{tabular}


TABLE 5.5-1. (Cont'd)

\begin{tabular}{|c|c|c|c|c|c|}
\hline $\begin{array}{l}\text { Sample } \\
\text { Number }\end{array}$ & Package Type & Labeled & Contents & $\begin{array}{r}\text { Beta-Gamma } \\
\left(\mathrm{dpm} / \mathrm{cm}^{2}\right)\end{array}$ & $\begin{array}{l}\text { Alpha } \\
\left(\mathrm{dpm} / \mathrm{cm}^{2}\right)\end{array}$ \\
\hline 330 & $"$ & $"$ & $"$ & .45 & .06 \\
\hline 331 & $"$ & $"$ & $"$ & .12 & .03 \\
\hline 332 & $"$ & $"$ & $"$ & 1.18 & .17 \\
\hline 333 & 2.5 ton cylinder & $\mathrm{UF}_{6}$ & full & .05 & .05 \\
\hline 334 & $"$ & $"$ & $"$ & .47 & .14 \\
\hline 335 & $"$ & $"$ & $n$ & .59 & .18 \\
\hline 336 & $"$ & $"$ & $"$ & .165 & .63 \\
\hline 337 & 14 ton cylinder & $"$ & $"$ & 1.46 & .80 \\
\hline 338 & $"$ & $"$ & $"$ & .02 & .15 \\
\hline 339 & 14 ton cylinder & $\mathrm{UF}_{6}$ & full & 1.58 & .54 \\
\hline 340 & " & $"$ & $"$ & .28 & .08 \\
\hline 341 & $"$ & $"$ & $"$ & .03 & Bkgrd \\
\hline
\end{tabular}

(a) The average background (Bkgrd) count rate for beta-ganma measurements of Yellowcake and $\mathrm{UF}_{6}$ was $172 \mathrm{cpm}$.

(b) The average background (Bkgrd) count rate for alpha measurements of Yellowcake and $\mathrm{UF}_{6}$ was $1 \mathrm{cpm}$. 
Table 5.5-2 contains the 2055 frequency distribution data points for beta-gamma contamination which were used in this study. The majority of the smears (89\%) showed contamination levels that were less than 30 $\mathrm{dpm} / \mathrm{cm}^{2}$ beta-gamma, while $65 \%$ of the total number of smears measured contained less than $10 \mathrm{dpm} / \mathrm{cm}^{2}$. One percent of the smears showed beta-gamma activity above the DOT nonexclusive use limits listed in 49 CFR 173.

The reported surface contamination levels for alpha contamination are contained in Table 5.5-3. The amount of contamination found on all samples is below the nonexclusive use limit of alpha contamination (22 $\mathrm{dpm} / \mathrm{cm}^{2}$ ) by at least one order of magnitude. All of the measured samples are also below the $10 \%$ relative error detection limit.

\subsubsection{Spent Fuel Cask Surface Sweating}

After decontamination, the removable surface contamination leve 1 associated with a spent fuel cask may increase with time by a process known as sweating. The amount of this increase is a function of the design of the cask surface, the method used for decontamination, and the properties of the radionuclides involved. Our industry contact indicated that this problem has been largely brought under control by careful design of the surfaces of newer spent fuel casks. We were unable to collect or find data that would quantify the amount of increase resulting from surface sweating for two basic reasons: 1) during our data collection, only a few spent fuel shipments were scheduled, and thus it was difficult to coordinate our data collection trips with these shipments, and 2) our major industry contact routinely decontaminated cask surfaces upon receipt to remove road dirt, and thus the actual level upon receipt prior to decontamination was not recorded. Also, our industry contact routinely decontaminated cask surfaces before release from the site to a factor of 10 below current limits. This was done to help avoid any problems that may result from surface sweating.

Even though we can not make a quantitative statement about the magnitude of this problem, our best information from industry sources indicates 


\section{TABLE 5.5-2 Frequency Distribution Data for Spent Fuel Shipments(a)}

\begin{tabular}{|c|c|c|c|c|c|c|c|c|c|c|}
\hline \multirow[b]{2}{*}{ SHIPMENT NUMEER } & \multicolumn{10}{|c|}{ 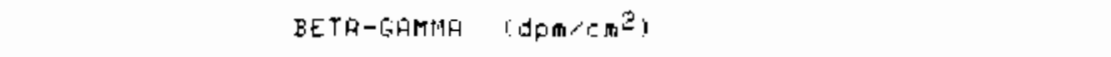 } \\
\hline & & $\# 1$ & & & & $\# 2$ & & & $\approx 3$ & \\
\hline CASK TOF & 5.4 & 2.2 & 2.6 & & $52 . \dot{8}$ & 52.5 & 75.9 & 20.5 & 16.9 & 9.9 \\
\hline CASK TOP (SIDE) & 19.9 & 19.6 & Eo. & & 183.6 & 52.5 & $7 \subseteq .9$ & 38.6 & 32.8 & 29.9 \\
\hline PRESSURE TEST PORT & 76.4 & & & & 19.9 & & & 1.5 & & \\
\hline PRESSURE RELIEF FORT & 79.5 & & & & 10.9 & & & 2.1 & & \\
\hline CAYITY VENT FORT & 3.0 & & & & 5.3 & & & 1.5 & & \\
\hline UPPER RUFTURE IISOS & 2.7 & 2.5 & & & 31.7 & 12.3 & & 1.5 & 1.5 & \\
\hline CASK SIDE (UPPER) & 25.4 & 19.4 & 25.3 & & 126.9 & 98.5 & 77.4 & 34.5 & 9.4 & 13.6 \\
\hline CASK SIDE (MIDDLE) & 79.7 & 41.8 & 57,7 & & 114.7 & 113.8 & 68.4 & 45.8 & 17.3 & 4.5 \\
\hline LOWER RUPTURE DISES & 13.5 & 18.1 & & & 35.0 & 31.8 & & 7.0 & 1.5 & \\
\hline CASK SIDE (LOWER) & 34.8 & 26.8 & 37.2 & & BP.7 & 78.9 & 78.8 & 54.4 & 22.5 & 16.5 \\
\hline CASK BASE (LEDGE) & 33.7 & 21.3 & 15.7 & & 48.3 & 17.5 & 18.2 & 38.7 & 8.3 & 7.9 \\
\hline CASK BASE (SIDE) & 60.0 & 46.4 & 26.6 & & $1: 33,3$ & 1.34 .2 & 145.2 & 46.2 & 28.3 & 15.9 \\
\hline DRAIN PORTS & 5.4 & 4.8 & & & 11.5 & 18.5 & & 5.7 & 5.0 & \\
\hline EASE BOTTOM & $1 E .7$ & 35.5 & 25.5 & & 179.9 & 89.5 & PE. & 15.1 & 8.7 & 15.3 \\
\hline TRUNIONS (UPPER & 51,4 & 30.1 & 15.1 & 9.6 & 91.8 & 28.4 & & 14.5 & 5.3 & \\
\hline TRUNIONS (LOLER) & 392.7 & 80.9 & 393.7 & 84.0 & 287.0 & 345.1 & & 13.3 & 39.7 & \\
\hline
\end{tabular}

\begin{tabular}{|c|c|c|c|c|c|c|c|c|c|}
\hline SNIPNEHT NUMEER & & $* 4$ & & ETA-EA & 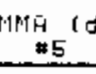 & $m<m^{2}$ & & $\omega$ & \\
\hline CASK TOP & 5.4 & 6.3 & 6.0 & 13.0 & 10.7 & 17.1 & 4.9 & 3.6 & 3.4 \\
\hline CASK TOP (SIDES) & 12.3 & 7.8 & 5.8 & $4 z \cdot 3$ & 19.9 & 13.5 & 3.7 & 3.7 & 4.9 \\
\hline PRESSURE TEST FURT & 2.1 & & & 4.2 & & & 2.5 & & \\
\hline PRESSURE RELIEF WÜLVE & $2 \cdot \hat{z}$ & & & 6.2 & & & 2.3 & & \\
\hline CAVITY VEHT FORT & 2.7 & & & 5.4 & & & 2.3 & & \\
\hline UPFER RUPTURE DISES & 2.6 & 4.1 & & 3.2 & 2.8 & & 1.5 & 1.5 & \\
\hline CASK SIDE IUPFERI & 28.7 & 29.4 & 31.6 & 16.5 & 3.4 & 5.4 & 2.5 & 2.1 & 1.5 \\
\hline CASK SIDE IMIDILEI & 21.7 & 17.1 & 24.2 & 15.5 & 6.7 & 4.2 & 2.2 & 8.9 & 5.9 \\
\hline LOWER RUPTURE DISCS & $2 \cdot 7$ & 2.0 & & 5.9 & 3.8 & & 1.5 & 1.5 & \\
\hline CASK SIDE (LOWER! & 25.9 & 22.6 & 17.6 & 20.6 & 8.8 & 6.9 & $3 . \epsilon$ & $\dot{E} \cdot 2$ & 1.6 \\
\hline CASK BASE (LEDGE) & 13.5 & 4.4 & 5.9 & 12.5 & 26.6 & 16.1 & $6 . \bar{T}$ & 6.7 & $4 \cdot \vec{i}$ \\
\hline CASK BASE (SIDE) & 18.1 & 9.0 & 5.8 & 24.6 & 12.8 & 15.5 & 7.4 & 13.7 & 6.4 \\
\hline DRAIH PQRTS & 3.1 & $4 \cdot 3$ & & 19.9 & 3.8 & & 1.5 & 1.5 & \\
\hline BASE BOTTON & 13.5 & 7.7 & 7.2 & 2.4 & 2.8 & 4.3 & 5.1 & 5.2 & 3.9 \\
\hline TRUNIONS (UPPEPI) & 6.7 & 7.3 & & 14.7 & 2.3 & & 8.8 & 8.9 & \\
\hline TRIJNIOHS (LOJER? & 3.6 & & & 1E. 다 & 13.6 & & 11.1 & P.Q & \\
\hline
\end{tabular}


TABLE 5.5-2 (Continued)

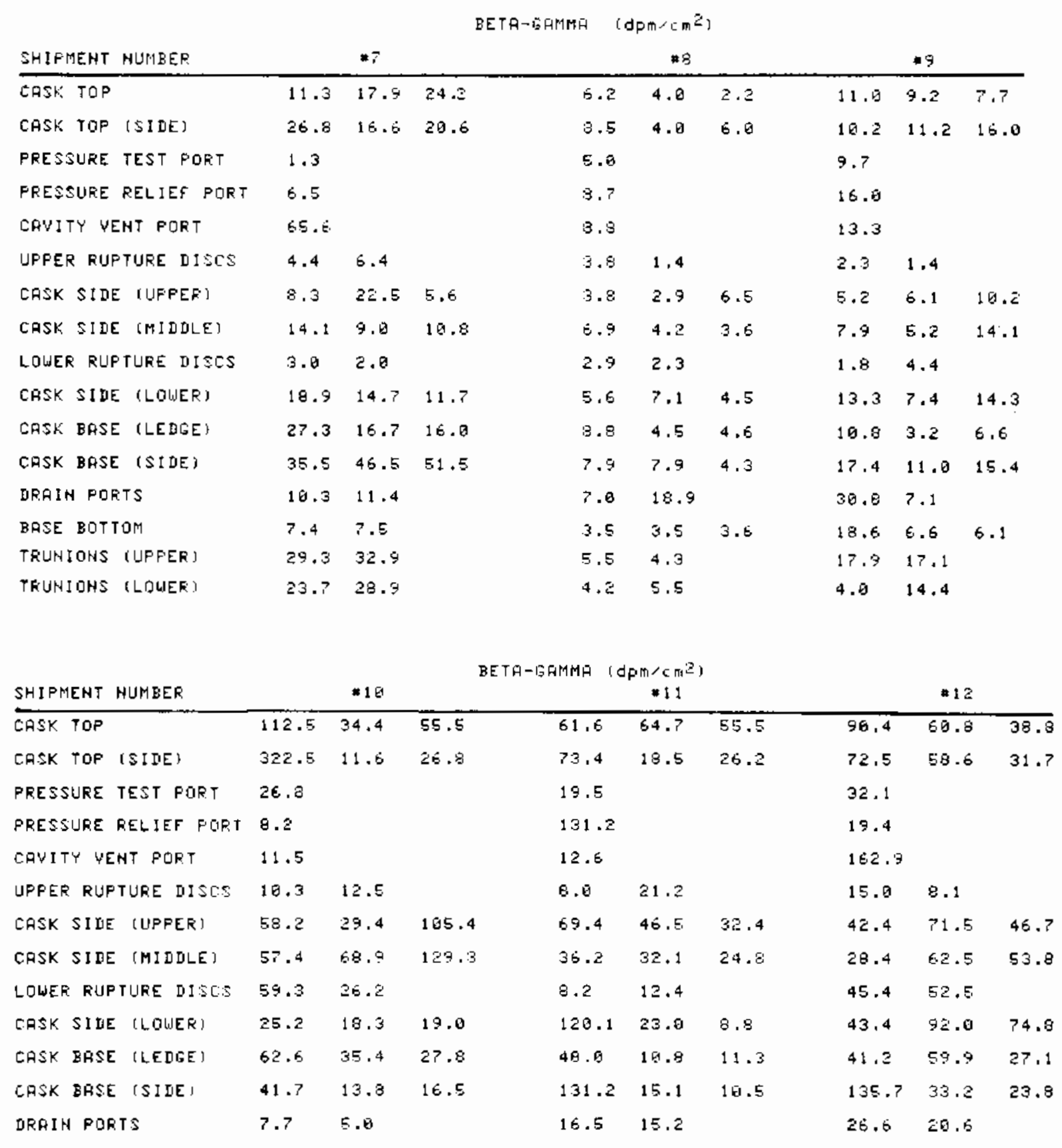




\section{TABLE 5.5-2 (Continued)}

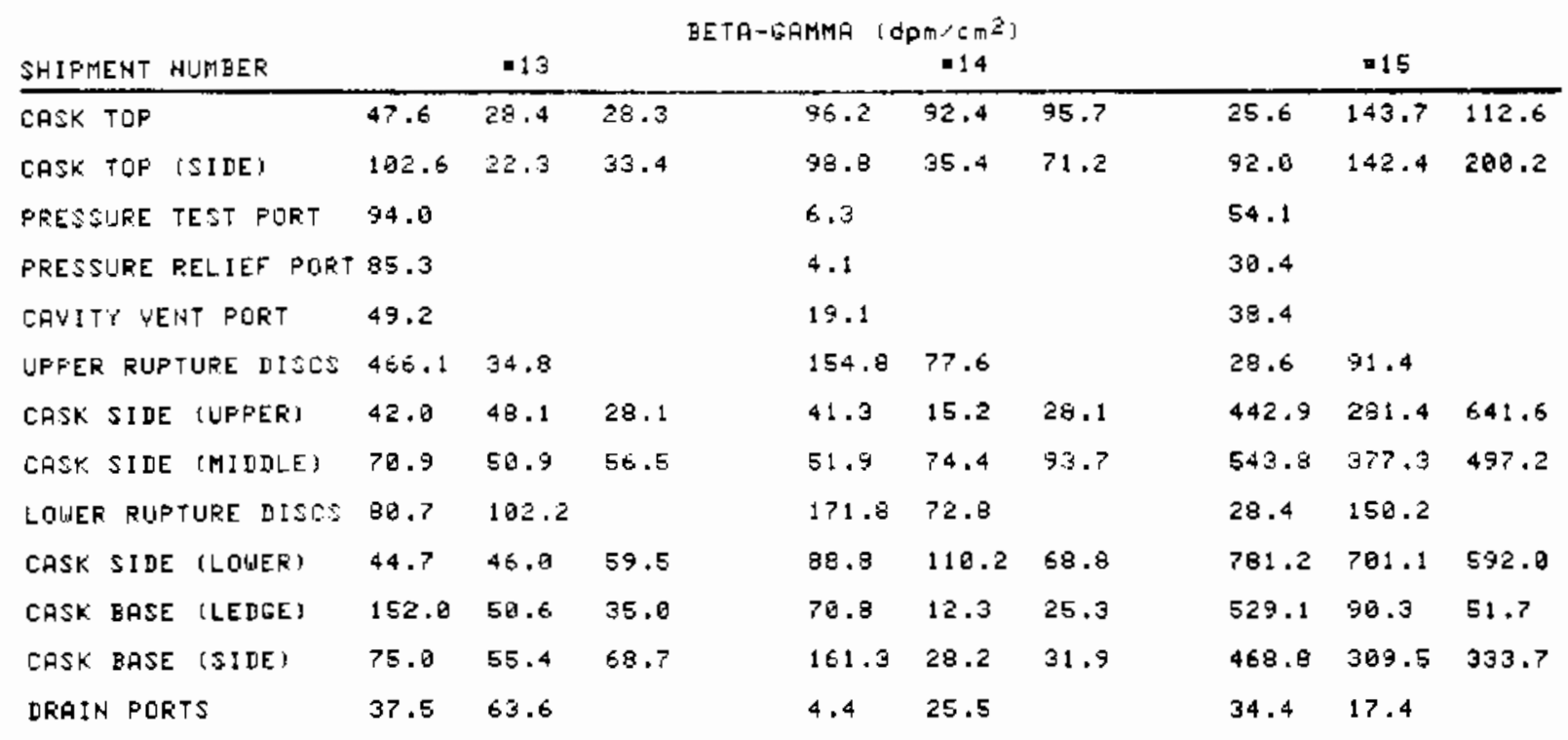

\begin{tabular}{|c|c|c|c|c|c|c|c|c|c|}
\hline SHIFMENT NUMBER & \multicolumn{8}{|c|}{ BETA-GAMMA $\left(d p m<C m^{2}\right)$} & \\
\hline CASK TOP & 16.3 & 9.3 & 3.2 & 13.5 & 22.5 & 10.5 & 3.6 & 2.4 & 2.0 \\
\hline CASK TOF (SIDE) & 4.2 & 14.6 & 15.5 & 10.5 & 7.5 & 19.5 & 9.5 & 6.9 & 2.3 .2 \\
\hline FRESSURE TEST FORT & 2.8 & & & 10.5 & & & 2.0 & & \\
\hline PRESSURE RELIEF PORT & 5.5 & & & 7.5 & & & 2.6 & & \\
\hline CAVITY VENT PORT & 1.3 & & & 4.5 & & & 3,5 & & \\
\hline UPPER RUPTIRE DISCS & 18.2 & 2.3 & & 4.5 & 7.5 & & 1.6 & 4.2 & \\
\hline CASK SIDE (UFPEF') & 15.3 & 12.4 & 22.7 & 7.5 & 4.5 & 10.5 & 1.0 & 4.3 & 2.4 \\
\hline CASK SIDE (MIDDLE) & 2.5 & 10.7 & 22.5 & 10.5 & 7.5 & 7.5 & 2.2 & 1.3 & 2.7 \\
\hline LOWER RUPTURE DISES & 15.3 & 14.0 & & 7.5 & 4.5 & & .1 & $2 \cdot 3$ & \\
\hline CASK SIDE (LOWER) & 7.7 & 12.2 & 24.1 & 13.5 & 10.5 & 7.5 & 2.3 & 2.1 & 1.9 \\
\hline CASK BASE (LEDGE) & 15.2 & 15.7 & 6.9 & 16.5 & 7.5 & 4.5 & 1.2 &.$\theta$ & 2.9 \\
\hline CASK BASE (SIDE) & 27.6 & 17.3 & & 34.5 & 16.5 & 4.5 & 2.9 & 2.6 & 1.8 \\
\hline DRAIH PORTS & 6.2 & 6.3 & & 10.5 & 4.5 & & 9.3 & 2.9 & \\
\hline BASE EOTTOM & 5.9 & 5.7 & 4.7 & 10.5 & 7.5 & $2 z .5$ & 3.7 & 4.4 & 3.1 \\
\hline TEUNHIDHS (UPPER) & 1.7 & 18.4 & & 4.5 & 4.5 & & 1.3 & 1.8 & \\
\hline TRLNNHIONS (LOWER) & 8.6 & 2.5 & & 4.5 & 4.5 & & .8 & 3.6 & \\
\hline
\end{tabular}


TABLE 5.5-2 (Continued)

\begin{tabular}{|c|c|c|c|c|c|c|c|c|c|c|}
\hline \multirow{2}{*}{$\frac{\text { SHIPMENT MUMBER }}{\text { CASK TOP }}$} & \multicolumn{7}{|c|}{ BETA-SAMMA $\begin{array}{c}\left(d \rho \pi / \mathrm{Cm}^{2}\right) \\
\end{array}$} & \multicolumn{3}{|c|}{$=21$} \\
\hline & 16.4 & 62.2 & 75.5 & & 1.5 & 1.6 & 1.4 & 32.6 & 43.19 & 24.5 \\
\hline CASK TOP (SIDE) & 35.7 & 39.5 & 32.7 & & 2.4 & 1.7 & 2.4 & 143.4 & 54.9 & 79.2 \\
\hline PRESSURE TEST PORT & 8.4 & & & & 2,2 & & & 15.9 & & \\
\hline PRESSURE RELIEF FORT & 12.9 & & & & .9 & & & 15.6 & & \\
\hline CAVITY VENT PORT & 7.9 & & & & $1 . t$ & & & 8.2 & & \\
\hline UPPER RUPTURE DISCS & 7.1 & 1.5 & & & 1.6 & 2.0 & & 4.2 & 5.4 & \\
\hline CASK SIDE (UPPER) & 34.9 & 22.4 & 41.7 & & 1.7 & .8 & 1.6 & 167.7 & 60.0 & 105.3 \\
\hline CASK SIDE (MIDDLE) & 80.8 & 47,7 & 45.1 & & 2.5 & 1.3 & 1.3 & 174.5 & 56.7 & 110.3 \\
\hline LOWER RUPTURE DISCS & 9.5 & 8.6 & & & 1.2 & 1.0 & & 27.8 & 7.2 & \\
\hline CRSK SIIE (LOWER) & 21.7 & 63.3 & 34.4 & & 1.7 & 1.6 & 1.3 & 205.2 & 19.2 & 11.1 \\
\hline CASK BASE (LEDGE) & 68.7 & 58.9 & 41.3 & & 1.8 & 1.8 & 1.5 & 103.3 & 2.5 & 3.6 \\
\hline CASK BASE (SIDE) & 15.2 & 12.6 & 25.2 & & 7.5 & 2.3 & 1.1 & 188.8 & 7.3 & 8.8 \\
\hline DRAIH PORTS & 12.7 & 6.8 & & & 2,5 & 2.1 & & 90.0 & 32.4 & \\
\hline BASE BOTTOM & 27.7 & 20.1 & 19.5 & & 1.4 & 1.4 & 1.45 & 26.5 & 16.4 & 27.8 \\
\hline TRUNNIONS (UFPER) & 12.6 & 39.9 & & & 1.4 & 1.4 & & 15.8 & 13.9 & \\
\hline TRUNHIONS (LOWER) & 6.3 & 3.7 & & & 1.4 & 1.4 & & 19.9 & 25.2 & \\
\hline & & & & BETA & - GAMM & $\operatorname{lgp} \pi / \varepsilon$ & & & & \\
\hline SHIPMENT HUMBEF & & & $* 22$ & & & & .23 & & & \\
\hline CASK TOP & & 105.0 & 93.5 & 93.8 & & 13.2 & 18.9 & 12.8 & & \\
\hline CASK TOP (SIDE) & & $119 \cdot 3$ & 19.2 & 35.1 & & 51.5 & $\epsilon .3$ & 18.3 & & \\
\hline PRESSURE TEST FORT & & 17.2 & & & & 92.6 & & & & \\
\hline PRESSURE RELIEF PORT & & 6.5 & & & & 8.7 & & & & \\
\hline CAVITY VENT PORT & & 9.9 & & & & 9.5 & & & & \\
\hline UFPER RUPTURE DISDS & & 36.7 & 13.3 & & & 6.5 & 5.7 & & & \\
\hline CASK. SIIE (UPPER) & & 81.7 & $6 E \cdot \dot{\theta}$ & 9.9 & & 7.4 & 19.6 & 14.4 & & \\
\hline CASK SIDE MIDDLE! & & 67.0 & 65.0 & 9.3 & & 22.1 & 39.7 & 20.8 & & \\
\hline LOWER RUPTURE DISES & & 22.5 & 10.1 & & & 9.7 & 14.2 & & & \\
\hline CASK SIDE (LOWER) & & 27.5 & 22.3 & 32.6 & & 26.1 & 36.4 & 19.6 & & \\
\hline CASK BASE [LEDGE] & & 42.9 & 15.9 & 18.2 & & 20.6 & 19.2 & 11.9 & & \\
\hline CASK BASE (SIDE) & & 113.7 & 19.8 & $1 \epsilon .5$ & & 44.8 & 6.2 & 5.7 & & \\
\hline DRAIH PQRTS & & 25.1 & 8.2 & & & 6.1 & 2.2 & & & \\
\hline
\end{tabular}




\section{TABLE 5.5-2 (Continued)}

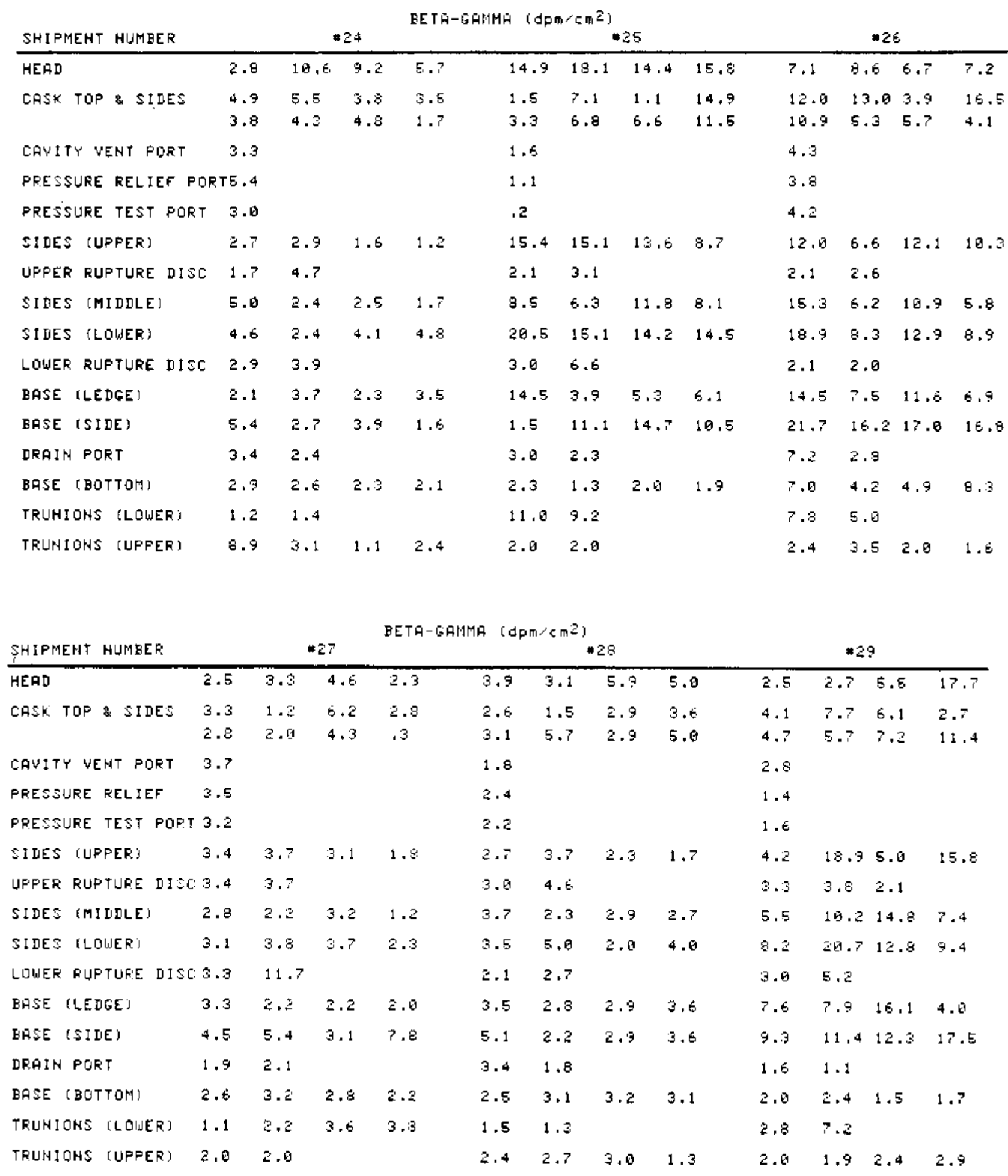




\section{TABLE 5.5-2 (Continued)}

\begin{tabular}{|c|c|c|c|c|c|c|c|c|c|c|c|c|}
\hline & & & & BETН̈- & F $1 d p$ & $m<\left\{\mathbf{n}^{2}\right\}$ & & & & & & \\
\hline SHIFMENT HIJMEER & & & $3 \theta$ & & & 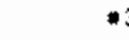 & 31 & & & -3 & & \\
\hline HEAD & 3.3 & 3.2 & 3.0 & 18.9 & 1.3 & 2.3 & 1.7 & 1.3 & 1.7 & 2.9 & 2.2 & 1.1 \\
\hline LASK TOF \& SIDES & 1.1 & 2.5 & 1.5 & 1.4 & 1.3 & 8.5 & 1.5 & 2.8 & 1.3 & 1.1 & 1.4 & 1.6 \\
\hline & 2.6 & 3.2 & 3.3 & 2.4 & 4.5 & 1.3 & $2 . t$ & 5.4 & 3.9 & 3.2 & 2.1 & 4.3 \\
\hline QAUITT VEHT FIRT & 3.5 & & & & 1.4 & 1.3 & & & 6.4 & & & \\
\hline PRESSURE RELIEF & $3 . \hat{2}$ & & & & 13.6 & & & & 11.8 & & & \\
\hline PFESEURE TEST FIDR & 5.7 & & & & 5.4 & & & & $? .7$ & & & \\
\hline SIDES (UPFERI & $2 \cdot 4$ & 2.7 & 1.0 & 1.8 & 1.6 & 3.2 & 1.3 & 3.8 & 1.2 & 1,5 & 3.0 & 4.9 \\
\hline UPPER RUPTURE IIIS & 6.0 & 4.7 & & & 5.1 & 2.3 & & & 3.2 & 6.4 & & \\
\hline SIDES (MIDDLE) & 1.9 & 3.2 & 3.2 & 2.3 & 4.7 & 2,5 & 3.4 & 6.8 & 2,0 & 2.2 & 2.3 & 2.7 \\
\hline SIDES ILOWEF! & 1.7 & 2.1 & 1.3 & 3.5 & 6.4 & 5.2 & 5.1 & 6.9 & 1.7 & 2.6 & 4.6 & 6.2 \\
\hline LEIUER RUPTURE DIS & 8.9 & 2.0 & & & 4.5 & 4.2 & & & 8.4 & 3.0 & & \\
\hline RA $\lesssim E$ (LEDLE) & 1.8 & 1.1 & 3.3 & 1.7 & 1.7 & 1.72 .7 & 4.7 & 2.26 .3 & 2.7 & 8.9 & 2.9 & 1.9 \\
\hline BASE (SIDE) & 5.0 & 1.3 & 3.2 & 3.3 & 1.3 & 5.3 & 2.7 & 2.9 & 7.9 & 8.7 & 2.9 & 2.6 \\
\hline DRAIN PORT & 3.2 & $z .4$ & & & 3.6 & 2.5 & & & 3.5 & 4.3 & & \\
\hline BASE (BOTTOM) & $2 \cdot 3$ & 1.7 & 2.9 & 3.2 & 18.4 & 1.3 & 9.4 & 2.6 & 2.2 & 1.8 & 4.4 & 2.7 \\
\hline TRUNIONS (LOWER) & 2.5 & 1.8 & 3.6 & 3.8 & 1.3 & $1 \cdot 3$ & & & 2.9 & 2.1 & & \\
\hline TFUNIONS IUPFER! & 2.2 & 2.4 & 16.5 & 4.7 & 10.4 & 9.6 & 1.7 & 1.9 & 10.7 & 2.9 & & \\
\hline
\end{tabular}

\begin{tabular}{|c|c|c|c|c|c|c|c|c|c|c|c|c|}
\hline & & & & EETA & Ia 19 & $\left\langle\pi \pi^{2}\right.$ & & & & & & \\
\hline SHIFNENT HUMEER & & & 33 & & & & 34 & & & -35 & & \\
\hline HEAD & 1.5 & 1.5 & 2.6 & 2.1 & 1.5 & 1.5 & 1.5 & 1.5 & 65.5 & 16.7 & 3.4 & 6.8 \\
\hline EASK TOF \& SIDES & 1.5 & 1.5 & 1.5 & 1.6 & 1.5 & 1.5 & 1.5 & 1.5 & 5.1 & 4.4 & 3.4 & 9.7 \\
\hline & 3.9 & 3.7 & 1.5 & 5.5 & 1.5 & 1.5 & 1.5 & 2.5 & 4.7 & 20.5 & 4.5 & 17.1 \\
\hline DAUITY WEHT PDET & 1.5 & & & & 1.6 & & & & 9.7 & & & \\
\hline FRESSURE RELIEF & 1.5 & & & & 1.5 & & & & 3.7 & & & \\
\hline PRESSIJEE TEST POF! & $T 1.5$ & & & & 1.5 & & & & 2.9 & & & \\
\hline SIDES (LIFFER) & 1.5 & 2.4 & 1.7 & 1.6 & 1.5 & 1.5 & 1.5 & 1.5 & 3.8 & 6.5 & $8 . \theta$ & 5.8 \\
\hline UPPER RUVFTURE DIS & $=1.6$ & 1.6 & & & 1.5 & 1.5 & & & 2.8 & 4.4 & & \\
\hline SIDES (MIUDLE) & 1.5 & 2.0 & 2.3 & 2.3 & 2.2 & 1.5 & 1.5 & 1.5 & 3.4 & 10.7 & 11.4 & 9.18 \\
\hline SIIEES (LOLUER) & 1.3 & 3.5 & 2.4 & 3.1 & 1.5 & 1.5 & 1.5 & 1.5 & $7 \cdot 1$ & 10.9 & 9.4 & 8.9 \\
\hline LOWER RIJPTLIRE DI & 01,3 & $1 . \dot{E}$ & & & 1,5 & 1.5 & & & 3.6 & 5.6 & & \\
\hline BASE (LEDLE) & 1.5 & 1.6 & 1.5 & 1.5 & 1.5 & 1.5 & 1.5 & 1,5 & 4.7 & 5.8 & 5.4 & 5.6 \\
\hline BASE (SIIE) & 1.5 & 1.7 & 1.6 & 1.5 & 1.5 & 1.5 & 1.5 & 1.5 & $6 . \hat{2}$ & 13.3 & 19.2 & $\in .4$ \\
\hline DEAIN PORT & 1.5 & 1.5 & & & 1.5 & 1,5 & & & 16.0 & 2.4 & & \\
\hline RASE IBOTTOMI & 1.5 & 1.5 & 1.5 & 1.5 & 1.5 & 1.5 & $1 . \bar{i}$ & 1.5 & 4.4 & 6.9 & 5.1 & 4.9 \\
\hline TRUMIDHS (LOWER) & 1.5 & 1.5 & & & 1.5 & 1.7 & & & 5.8 & 5.4 & & \\
\hline TRUNI OHE IIJPPEF: I & 1.9 & 1.5 & 1.5 & 1.5 & 1.5 & 2.1 & 1.5 & 1.8 & 5.7 & 1,8 & 5.0 & 2.7 \\
\hline
\end{tabular}




\section{TABLE 5.5-2 (Continued)}

\begin{tabular}{|c|c|c|c|c|c|c|c|c|c|c|c|c|}
\hline \multirow{2}{*}{$\begin{array}{l}\text { SHIPMENT NUMFER } \\
\overrightarrow{H E A D}\end{array}$} & \multicolumn{12}{|c|}{ 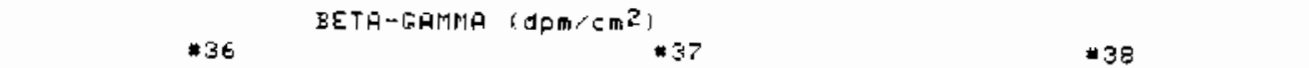 } \\
\hline & 1.3 & 1.3 & 2.6 & 1.3 & 13.9 & 2.8 & 2.4 & 3.7 & 3.9 & 5.1 & 7.3 & 9.0 \\
\hline CASK TOP \& SIDES & 1.3 & 1.3 & 3.5 & 2.6 & 8.5 & 7.2 & $1 \epsilon_{1} \cdot 9$ & 16.6 & 3.5 & 2.0 & 5.5 & 3.8 \\
\hline & 4.4 & 2.3 & 2.5 & 1.5 & 2.3 & 5.0 & 5.9 & 5.3 & 10.4 & 5.7 & 5.5 & 1.3 \\
\hline CAVITY VENT PQET & 2.3 & & & & 2.2 & & & & 7.7 & & & \\
\hline PRESSURE RELIEF & 1.3 & & & & 1.0 & & & & 1.7 & & & \\
\hline PRESSURE TEST FORT & $T 1,3$ & & & & 1.4 & & & & 1.4 & & & \\
\hline SIDES (LPPER) & 1.6 & 1.3 & 1.3 & 1.3 & 5.8 & 21.2 & $2 \overline{6}, 9$ & 12.9 & 2.7 & 2.5 & 2.2 & 1.8 \\
\hline IPFER RUPTURE DISC & $=1.3$ & 1.3 & & & 1.9 & 3.4 & & & 1.4 & 1.4 & & \\
\hline SIDES (MIDDLE) & 1.9 & 1.3 & 1.3 & 1.3 & 4.7 & 20.3 & 15.7 & 15.18 & $E .1$ & 1.5 & 3.7 & 4.6 \\
\hline SIDES (LOWER) & 1.3 & 1.3 & 1.4 & 1.8 & 10.3 & 17.5 & $1 \vec{r} \cdot 9$ & 14.2 & 2.7 & 3.5 & 2.6 & 4.4 \\
\hline LOLER RIJPTURE DISC & $=1.3$ & 1.3 & & & 2.3 & 1.4 & & & 5.3 & 1.4 & & \\
\hline BASE (LEDGE) & 3.4 & 1.3 & 1.3 & 1.3 & 5.2 & 6.9 & 5.2 & 3,3 & 1.7 & 1.7 & 4.1 & 1.4 \\
\hline BRSE (5IDE) & 1.3 & 1.3 & 1.7 & 1.3 & 3.7 & 7.2 & 15.8 & 3.7 & 1.4 & 2.8 & 1.7 & 1.4 \\
\hline DRAIN PORT & 1.3 & 1.3 & & & 1.9 & 3.3 & & & 1.4 & 1.4 & & \\
\hline BASE (BOTTOM) & 1.3 & 1.3 & 1.7 & 1.3 & 1.7 & 2.1 & 3.4 & 3.6 & 3,9 & 1.4 & 1.4 & 1.5 \\
\hline TRIJNIONS (LOLER) & 7.3 & 1.3 & & & 4.9 & 4.2 & & & 1.4 & 2.0 & & \\
\hline TRUNIONS (UPPER) & 1.3 & 1.3 & 1.3 & 1.3 & 2.0 & 2.9 & & & 6.3 & 2.0 & 3.1 & 2.8 \\
\hline SHIPMENT HUMBEF' & & & 39 & BETH-GAMMA & a $\operatorname{lopm}$ & $\left(c m^{2}\right)$ & 40 & & & $\$ 41$ & & \\
\hline HEAD & 8.3 & 2.2 & 3.2 & 2.2 & 2.6 & 2.8 & 2.8 & 4.4 & 4.2 & 5.0 & 7.8 & 11.3 \\
\hline CASK TOP \& SIOES & 2.6 & 3.2 & 7.9 & 1.4 & 3.2 & 6.3 & 15.2 & 9.1 & 2.6 & 3.6 & 7.4 & 3.2 \\
\hline & 1.6 & 9.9 & 2.5 & 1.9 & 4.3 & 17.6 & 5.2 & 2.4 & - & - & - & - \\
\hline CAVITY VENT PORT & 4.4 & & & & 12,0 & & & & 1.2 & & & \\
\hline PRESSURE RELIEF & 4.6 & & & & 26.6 & & & & 4,3 & & & \\
\hline PRESSURE TEST PORT Z & 2.9 & & & & 3.6 & & & & 2.3 & & & \\
\hline SIUES (UPPER) & 1.6 & 1.6 & 2.8 & 1.9 & 2.4 & 0.5 & 6.1 & 9.8 & 9.5 & 6.1 & 7.5 & 6.8 \\
\hline UPPER RUPTURE DISE & 4.2 & 2.8 & & & 5.7 & 19.5 & & & 14.1 & 7.3 & & \\
\hline SIDES (MIDDLE) & 2.0 & 2.0 & 2.2 & $3 . \dot{6}$ & 7.3 & 12.0 & 10.1 & 8.8 & $>.1$ & 6.0 & 9.7 & 7.9 \\
\hline SILES (LOUER) & 2.6 & 3.3 & 2.7 & 3.1 & 7.1 & 7.9 & 15.4 & 13.9 & 20.1 & 16.2 & 17.6 & 14.8 \\
\hline LOWER RUPTURE DISE & 2.3 & 4.7 & & & 5.5 & 7.0 & & & $12 \cdot 2$ & 3.6 & & \\
\hline EASE (LEDGE) & 1.8 & 7.9 & 2.6 & 1,3 & 12.7 & 15.5 & 19.4 & 5.8 & 5.6 & 5.7 & 15.3 & 5.7 \\
\hline BASE (SIDE) & 8.0 & 1.4 & 9.1 & 2.9 & 8.8 & 11.6 & 9.1 & 2.7 & 26.9 & 1 घ.1 & 17,4 & 8.1 \\
\hline DRAIH PORT & 3.2 & 3.1 & & & 12.6 & 9.8 & & & 14,4 & 3.3 & & \\
\hline BASE (BOTTOM) & 3.2 & 3.2 & 8.3 & 3.9 & 7.0 & 9.2 & 8.4 & $8 . \overline{0}$ & 6.5 & 7.6 & 13.7 & 5.8 \\
\hline TRUN!ONS [LOLER] & 5.5 & 3,5 & & & 7.7 & 7.2 & & & 11.3 & 12.5 & & \\
\hline TRUNIOHS (UPFER) & 5.4 & 15.9 & 2.7 & 2.1 & 2,4 & 3.9 & & & - & - & - & - \\
\hline
\end{tabular}




\section{TABLE 5. 5-2 (Continued)}

\begin{tabular}{|c|c|c|c|c|c|c|c|c|c|c|c|c|}
\hline \multirow{2}{*}{$\begin{array}{l}\text { SHIPMENT HUMBER } \\
\text { HEAD }\end{array}$} & \multicolumn{8}{|c|}{ BETA-BAMMA $\quad$ apm ent } & \multicolumn{4}{|c|}{$* 44$} \\
\hline & 4.6 & 2.4 & 7.8 & 10.7 & 3.2 & 5.7 & 5.8 & 3.1 & 5.0 & 4.13 & 5.1 & 5.5 .3 \\
\hline CASK TOP \& SIDES & 3.4 & 6.5 & 4.3 & 6.4 & 9.1 & 13.2 & $2 \cdot 3$ & 4.5 & 8.9 & 6.8 & 13.7 & 7.2 \\
\hline & 15.6 & 7.9 & 13.5 & 8.4 & 5.4 & 5.3 & 3.7 & 8.9 & 8.4 & 13.8 & 7.2 & 16.7 \\
\hline CAUITY YENT PORT & 2.7 & & & & 9.8 & & & & 12.9 & & & \\
\hline PRESSURE RELIEF & 17.5 & & & & 6.8 & & & & 16.5 & & & \\
\hline PRESSURE TEST PORT & 7.4 & & & & 6.5 & & & & 17.3 & & & \\
\hline SIDES (UPPER) & 15.8 & 10.5 & 15.0 & 9.7 & 10.0 & 7.5 & 5.1 & 6.5 & 6.8 & 10.1 & 6.7 & 12.6 \\
\hline UFPER RUPTURE DISC & 3.1 & 4.4 & & & 19.1 & 11.1 & & & 3.0 & 7.7 & & \\
\hline SIDES (MIDDLE) & 13.0 & 9.6 & 8.1 & 12.8 & 4.1 & 3.8 & $7 . \overline{9}$ & 8.1 & 15.3 & 14.2 & 8.6 & 16.8 \\
\hline SIDES (LOWER) & 20.3 & 18.5 & 12.8 & 7.1 & 5.7 & 4.0 & 3.5 & 5.5 & 19.5 & 6.9 & 18.6 & 11.6 \\
\hline LOWER RUPTURE DISC & 13.0 & 5.4 & & & 2.7 & 3.5 & & & 4.3 & $\epsilon .0$ & & \\
\hline BASE (LEDGE) & 5.1 & 11.3 & 9.9 & 4.4 & $\leqslant .2$ & 4.9 & 6.3 & 4.8 & 5.5 & $P . \epsilon$ & 14.7 & 4.7 \\
\hline BASE (SIDE) & 4.6 & 21.4 & 7.1 & 16.0 & 6.9 & 7.3 & 5.8 & 5.5 & 8.3 & 9.5 & 6.9 & 5.3 \\
\hline DRAIN PORT & 12.6 & 13.8 & & & 13.1 & 8.6 & & & 20.9 & 9.7 & & \\
\hline BASE (BOTTOM) & 8.7 & 82 & 3.2 & 14.0 & 4.2 & 4.0 & 5.3 & 5.0 & 4.8 & 3.2 & 3.1 & 4.1 \\
\hline TRUHIONS (LOWER) & 5.1 & 2.3 & & & 5.0 & 7.0 & & & 4.1 & 5.1 & & \\
\hline TRUNIONS CUPPER? & 2.8 & 8.4 & 4.1 & 5.9 & 6.7 & 4.8 & 8.5 & 6.8 & 3.7 & 5.6 & 18.7 & 8.7 \\
\hline
\end{tabular}

\begin{tabular}{|c|c|c|c|c|c|c|c|c|c|c|c|c|c|}
\hline \multicolumn{2}{|l|}{ SHIPMEHT HUMBER } & \multicolumn{8}{|c|}{ 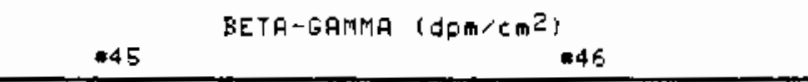 } & \multicolumn{4}{|c|}{$\$ 47$} \\
\hline HEAD & 5.1 & 7.2 & 7.1 & 5.3 & 1,3 & $\begin{array}{ll}3.45 \\
5.5 & 1\end{array}$ & $5.7 \quad 13$ & $3: 4$ & 4.4 & 12.1 & 16.0 & 10.6 & 10.4 \\
\hline CASK TOP \& SIDES & $\begin{array}{c}7.0 \\
-\end{array}$ & $\begin{array}{c}11.5 \\
-\end{array}$ & $\begin{array}{c}9.6 \\
-\end{array}$ & $\begin{array}{c}16.9 \\
-\end{array}$ & 16,9 & $\begin{array}{ll}5.0 & 1 \\
3.1 & 1\end{array}$ & $\begin{array}{ll}.3 & 16 \\
4.4 & 6\end{array}$ & .0 & $\begin{array}{l}10.8 \\
13.1\end{array}$ & $\begin{array}{l}13.2 \\
4.67\end{array}$ & $\begin{array}{l}4 . \vec{r} \\
.220 .\end{array}$ & $\begin{array}{l}9.6 \\
.17 .6\end{array}$ & $\begin{array}{l}10.7 \\
12.3\end{array}$ \\
\hline CAUITY VENT FORT & 11.3 & & & & 4.3 & & & & & 15.1 & & & \\
\hline PRESSURE RELIEF & 9.1 & & & & 11.3 & & & & & 17.3 & & & \\
\hline PRESSURE TEST POR & $T 13.7$ & & & & 6.5 & 10.2 & & & & 19.3 & & & \\
\hline SIDES (UPPER) & 16.1 & 18.5 & 18,4 & 15.9 & 16.2 & 6.9 & 5.4 & & .2 & 14.9 & 13.5 & 11.9 & 5.0 \\
\hline UPPER RUPTURE DIS & 0.1 & 6.4 & & & 9.3 & 4.1 & & & & 5.3 & 11.0 & & \\
\hline SIDES (MIDDLE) & 12.4 & 13.1 & 20.2 & 13.0 & 6.5 & 6.8 & 7.3 & 8.8 & 9.1 & 12.4 & 8.0 & 5.4 & 5.0 \\
\hline SIDES (LOWER) & 17.9 & 11.2 & 17.2 & 16.6 & 15.1 & 3.3 & 7.6 & 10.8 & 4.9 & 4.5 & 5.8 & 2.2 & 5.1 \\
\hline LOUER RUPTURE DIS & C11.0 & $6 . B$ & & & 9.6 & 2.1 & & & & 4.2 & 13.2 & & \\
\hline BASE (LEDGE) & 16.8 & 12.4 & 12.2 & 13.6 & 4.3 & 7.2 & 12.7 & 3 & 3.9 & \pm 6.0 & 11.7 & 10.6 & 10.1 \\
\hline BASE (SIDE) & $\$ 5.0$ & 9.0 & 18.13 & 13.7 & 2.9 & 5.8 & 13.5 & 2.4 & 2.8 & 8.6 & 13.2 & 6.0 & 8.5 \\
\hline DRRIN PORT & 13.6 & 14.5 & & & 11.5 & 14.6 & & & & 3.0 & 18.8 & & \\
\hline BASE (BOTTUM) & 3.3 & 16.9 & 15.8 & 15.4 & 2.6 & 1.54. & 82.2 & 1.8 & $E .0$ & 5.9 & 4.8 & 6.8 & 4.6 \\
\hline TRUNIONS (LOWER) & 8.1 & 10.5 & & & 2.9 & 5.7 & & & & 11.2 & 20.8 & & \\
\hline TRUNIONS (UPPER) & 2.0 & 2.0 & & & 2.0 & 2.0 & & & & 3.5 & 2,6 & 7.0 & 8.5 \\
\hline
\end{tabular}




\section{TABLE 5.5-2 (Continued)}

\begin{tabular}{|c|c|c|c|c|c|c|c|c|c|}
\hline \multirow{2}{*}{$\begin{array}{l}\text { SHIFMENT HUMBER } \\
\text { HEAI }\end{array}$} & \multicolumn{5}{|c|}{ 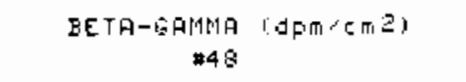 } & & & & \\
\hline & 2.7 & 2.7 & 3.1 & 2.7 & & & & & \\
\hline CASk TOP SIUES & 7.0 & 5.6 & 6.2 & 2.3 & & & & & \\
\hline & 1.4 & 4.7 & - & - & & & & & \\
\hline LAYITY VENT PORT & 19.4 & & & & & & & & \\
\hline PRESSURE RELIEF PDRT & $7, e$ & & & & & & & & \\
\hline FRESSURE TEST FORT & 13.1 & & & & & & & & \\
\hline SIDES (UPFER) & 4,3 & 10.6 & 8.6 & 8.3 & & & & & \\
\hline IJPFER RUPTURE DISC PORT & 2.6 & 4.0 & & & & & & & \\
\hline SIDES (MIDDLE) & 16.9 & 15.6 & 5.8 & 5.7 & $E .0$ & 14.4 & 10.9 & 14.0 & 12.6 \\
\hline SIDES (LOUER) & 13.2 & 9.9 & 5.0 & $a, 1$ & & & & & \\
\hline LOWER RUPTURE DISC PORT & 7.8 & 10.4 & & & & & & & \\
\hline BASE (LEDGE) & 6.4 & 6.9 & 8.7 & 7.3 & & & & & \\
\hline BASE (SIDE) & 9.1 & 7.4 & 7.2 & 11.0 & & & & & \\
\hline DRAIN FDRT & 12.0 & 4.3 & & & & & & & \\
\hline EASE (BOTTOM) & 8.3 & 7.3 & 6.1 & 2.4 & & & & & \\
\hline TRUNIONS (LOWER) & 8.5 & 12.8 & & & & & & & \\
\hline TRUUHIOHS (UFPER) & 3.5 & 1.5 & 1.7 & & & & & & \\
\hline
\end{tabular}

(a) The data was obtained from industry records for 48 spent fuel cask shipments between 1978 and 1980 . 
TABLE 5.5-3 Frequency Distribution Data for

\section{Spent Fuel - Alpha}

\begin{tabular}{|c|c|c|c|c|c|c|c|c|c|c|c|c|}
\hline \multirow[b]{2}{*}{ SHIPMENT NUMBER } & \multirow[b]{2}{*}{1} & \multirow[b]{2}{*}{2} & \multirow[b]{2}{*}{3} & \multirow{2}{*}{$\begin{array}{l}\text { ALPHA } \\
4\end{array}$} & \multicolumn{3}{|c|}{ CONTAMINIATION } & \multicolumn{2}{|c|}{$\left(\mathrm{dpm} / 100 \mathrm{~cm}^{2}\right)$} & \multirow[b]{2}{*}{10} & \multirow[b]{2}{*}{11} & \multirow[b]{2}{*}{12} \\
\hline & & & & & 5 & 6 & 7 & 8 & 9 & & & \\
\hline CASK TOP & $<34$ & 34 & $<21$ & $<21$ & HD & $<21$ & $<21$ & $\therefore 31$ & $<31$ & $<13$ & HD & 18 \\
\hline CASK TOP (SIDE) & $<34$ & $<31$ & $<21$ & $<21$ & NI & $\langle z \downarrow$ & $\Longleftrightarrow 21$ & $\therefore 31$ & $<31$ & 413 & ND & 6 \\
\hline PRESSURE TEST PORT & $<34$ & $<31$ & $<21$ & $<21$ & ND & $<21$ & $<z 1$ & 6.31 & $<31$ & $<13$ & ND & $<6$ \\
\hline PRESSURE RELIEF PORT & $<34$ & $<31$ & $<21$ & $<21$ & HD & $<21$ & $<2 \downarrow$ & $<31$ & $<31$ & 413 & $N D$ & $\epsilon$ \\
\hline CAYITY YENT PART & $<34$ & $<31$ & $<21$ & $<21$ & NI & $<2 !$ & $<21$ & 631 & $\therefore 31$ & $<13$ & HD & 6 \\
\hline UPPER RUPTURE DISCS & $<34$ & $<31$ & $<2 !$ & $<21$ & $\mathrm{NV}$ & $\ll 21$ & $<21$ & $<31$ & $<31$ & 13 & NI & $<6$ \\
\hline CASK SIDE (UFPER) & $<34$ & $<31$ & $<21$ & $<21$ & ND & $<21$ & $<21$ & 31 & $<31$ & $<13$ & ND & $\epsilon$ \\
\hline CASK SIDE (MIDDLE) & $<34$ & $<31$ & $<21$ & $<21$ & NI & $\ll 21$ & $<21$ & 31 & $<31$ & $<13$ & $\mathrm{NO}$ & $<6$ \\
\hline LOWER RUPTURE DISCS & $(34$ & - & $<21$ & $<21$ & ND & $<21$ & $<21$ & $<31$ & $<31$ & 413 & ND & 6 \\
\hline CASK SIDE (LQWER) & $<34$ & 51 & $<21$ & $<21$ & $N D$ & $<21$ & $\leqslant 21$ & $<31$ & $<31$ & 413 & ND & $<6$ \\
\hline EASK BASE (LEDGE) & $<34$ & $<31$ & 46 & $<22$ & $\mathrm{ND}$ & «a & $<2 !$ & $<31$ & $<31$ & 413 & HD & 6 \\
\hline CASK BRSE ISIDE) & $<34$ & $<31$ & $<21$ & $<21$ & ND & $<21$ & 31 & $\{31$ & $<31$ & $<13$ & $\mathrm{NI}$ & $\epsilon$ \\
\hline SRAIH PORTS & $<34$ & $<3 !$ & $<21$ & $<21$ & $\mathrm{HD}$ & $<21$ & $<21$ & $<3 !$ & $<3$ & 413 & ND & $<\epsilon$ \\
\hline BASE BOTTOM & $<34$ & $<31$ & $<21$ & $<21$ & ND & $<21$ & $\langle 2 \downarrow$ & $\therefore 31$ & $<31$ & - & - & - \\
\hline TRUNHIOHS (UPPER) & 34 & $<31$ & $<21$ & $<21$ & NI & $<21$ & $<21$ & $<31$ & $<31$ & * & - & - \\
\hline TRUNNIONS (LOWER) & 51 & as & $<21$ & $<2 !$ & ND & $<2 !$ & $<21$ & $<31$ & $<31$ & - & - & - \\
\hline
\end{tabular}

\begin{tabular}{|c|c|c|c|c|c|c|c|c|c|c|c|}
\hline \multirow[b]{2}{*}{ SHIFMENT NUMBER } & \multirow[b]{2}{*}{13} & \multirow[b]{2}{*}{14} & \multirow[b]{2}{*}{15} & \multirow{2}{*}{$\begin{array}{l}\text { RLPNA } \\
16\end{array}$} & \multicolumn{3}{|c|}{ CONTAMIHIATIOH } & \multicolumn{2}{|c|}{$\left(\mathrm{dpm} / 100 \mathrm{~cm}^{2}\right)$} & \multirow[b]{2}{*}{22} & \multirow[b]{2}{*}{23} \\
\hline & & & & & 17 & 18 & 19 & 20 & 21 & & \\
\hline CASK TOP & $\langle 47$ & $<13$ & $<13$ & ND & $<21$ & ND & $N D$ & NII & $<3 !$ & $<13$ & $<13$ \\
\hline CASK TOP (SIJE) & $\langle 4\rangle$ & $<13$ & $<13$ & HD & $<21$ & ND & HD & ND & $<31$ & $<13$ & $<13$ \\
\hline PRESSURE TEST PORT & $<47$ & $<13$ & $<13$ & ND & $<21$ & ND & ND & ND & $<31$ & $<13$ & $<13$ \\
\hline PRESSURE RELIEF PORT & $\langle 4\rangle$ & $<13$ & $<13$ & HD & $<21$ & $\mathrm{ND}$ & ND & ND & $<31$ & $<13$ & $<13$ \\
\hline CAVITY VENT PORT & $\langle 4 \vec{P}$ & $<13$ & $<13$ & ND & $<21$ & HD & $\mathrm{ND}$ & ND & $<31$ & $<13$ & $<13$ \\
\hline UPPER RUPTURE DISCS & $\langle 4\rangle$ & $<13$ & 613 & ND & $<21$ & ND & ND & ND & $<31$ & 13 & $<13$ \\
\hline CASK SIDE (UPPER) & $\langle 4\rangle$ & $<13$ & $\preccurlyeq 13$ & ND & $<21$ & ND & Ho & ND & $<31$ & $<13$ & $<13$ \\
\hline CASK SIDE (MIIILE) & $<47$ & 413 & $<13$ & ND & $<21$ & ND & ND & $N D$ & $<31$ & $<13$ & 413 \\
\hline LOWER RUPTURE DISCS & $<47$ & $<13$ & $<13$ & $\mathrm{ND}$ & 21 & ND & ND & ND & $<31$ & $<13$ & $<13$ \\
\hline CASK SIDE (LDWER) & $\langle 4\rangle$ & $<13$ & $<13$ & ND & $<21$ & ND & ND & ND & 46 & $<13$ & $<13$ \\
\hline CASK BASE (LEDGE) & $<47$ & $4: 3$ & $<13$ & ND & $<21$ & ND & ND & ND & $<31$ & $<13$ & $<13$ \\
\hline CASK BRSE (SIDE) & $<47$ & $<13$ & $<13$ & $H D$ & $<21$ & ND & ND & NI & $<31$ & $<13$ & : 13 \\
\hline DRAIN PORTS & $<47$ & 413 & $<13$ & ND & $<21$ & ND & MI & ND & $<31$ & $\ll 13$ & $<13$ \\
\hline BASE BOTTOM & - & - & - & WD & $<21$ & ND & ND & $<21$ & $<31$ & - & - \\
\hline TRUNAIONS (UPPEE] & - & - & - & ND & «1 & nI & ND & $<21$ & 431 & - & - \\
\hline TRUHNIONS (LOWER) & - & - & - & $\mathrm{ND}$ & $<21$ & ND & ND & 31 & $<31$ & - & - \\
\hline
\end{tabular}




\section{TABLE 5.5-3 (Continued)}

\begin{tabular}{|c|c|c|c|c|c|c|c|c|c|c|c|c|c|}
\hline \multirow[b]{2}{*}{ SHIPMENT HUMEER } & \multirow[b]{2}{*}{24} & \multicolumn{6}{|c|}{ RLFHA CONTAMINATIOYH } & \multicolumn{2}{|c|}{$\left(\mathrm{dpm} / 100 \mathrm{~cm}^{2}\right)$} & \multirow[b]{2}{*}{33} & \multirow[b]{2}{*}{34} & \multirow[b]{2}{*}{35} & \multirow[b]{2}{*}{36} \\
\hline & & 25 & 26 & 27 & 28 & 29 & 30 & 31 & 32 & & & & \\
\hline NEAD & ND & $<21$ & HD & $\mathrm{NI}$ & ND & $<13$ & ND & $<21$ & 832 & $<21$ & $<21$ & HD & $<21$ \\
\hline CASK TOP AND SIDES & $\mathrm{HII}$ & $<21$ & NI & $M D$ & $\mathrm{HI}$ & $<13$ & HI & $\langle 21$ & 132 & $<21$ & $<2$ & $\mathrm{HD}$ & $<21$ \\
\hline CAWITY VENT PURT & HD & $<21$ & HD & ND & ND & $\therefore 13$ & ND & $<21$ & 42 & $<21$ & $\vdots 21$ & $N D$ & $<21$ \\
\hline PRESSURE RELIEF & $\mathrm{WD}$ & $\{21$ & $\mathrm{NH}$ & $\mathrm{NIJ}$ & $\mathrm{NIJ}$ & $<13$ & $N D$ & $<21$ & $<32$ & $<21$ & $<21$ & HD & <2! \\
\hline FRESSURE TEST PORT & WD & $<21$ & $N D$ & $\mathrm{HI}$ & NI & $<13$ & $\mathrm{ND}$ & $<21$ & $<32$ & $<21$ & $\zeta z \downarrow$ & $N I$ & $\langle 21$ \\
\hline SIDES (UPPER) & ND & $\langle 2 !$ & $N D$ & ND & ND & $<13$ & ND & $<21$ & $<3$ & $<21$ & 21 & ND & $<21$ \\
\hline UPPER RUPTURE DIEC & ND & $<21$ & $M D$ & $\mathrm{HD}$ & $\mathrm{HD}$ & $<13$ & $\mathrm{HD}$ & $<21$ & $<32$ & $<21$ & $<21$ & ND & $<21$ \\
\hline SIDES (MIDDLE) & $N D$ & $<21$ & $N D$ & ND & $\mathrm{MI}$ & $\$ 3$ & ND & $<21$ & 32 & $<21$ & 821 & ND & $<21$ \\
\hline SIDES (LOWER) & HD & $<21$ & HII & HI & ND & $<13$ & $N D$ & $<21$ & $<32$ & $<21$ & $<21$ & $\mathrm{HD}$ & $<21$ \\
\hline LOWER RUPTURE DISC. & $N D$ & $<21$ & $M D$ & $N D$ & $\mathrm{HI}$ & $<13$ & $\mathrm{HI}$ & <21 & $<32$ & $<21$ & 28 & $N D$ & $<21$ \\
\hline BRSE (LEDGE) & $H D$ & $<21$ & $\mathrm{ND}$ & NII & ND & $<13$ & $N D$ & $<21$ & $<3 z$ & 221 & $<31$ & ND & 21 \\
\hline BASE (SIDE) & NJ & $\langle\hat{z} 1$ & $\mathrm{ND}$ & $H D$ & ND & $<13$ & ND & $<21$ & $<32$ & $<21$ & $<21$ & $\mathrm{ND}$ & $<21$ \\
\hline DRAIN PORT & ND & $<21$ & ND & $\mathrm{ND}$ & ND & $<13$ & $N D$ & $<21$ & $<32$ & $<21$ & $<21$ & ND & $<21$ \\
\hline BASE (BOTTAM) & ND & $<21$ & ND & ND & $\mathrm{HL}$ & $<13$ & $\mathrm{HD}$ & $<2$ & $<32$ & $<21$ & $<21$ & NI & $<2 !$ \\
\hline TRUNIONS (LOWER) & ND & $<2 !$ & ND & $\mathrm{NI}$ & $N D$ & $<13$ & ND & $<21$ & $<32$ & $<21$ & $<z 1$ & nI & $<21$ \\
\hline TRIJNIONS (UPPER) & $4 \pi$ & $<21$ & $\mathrm{ND}$ & ND & ND & $<31$ & ND & $\langle 21$ & $<32$ & $<21$ & $<21$ & HI & $\langle 21$ \\
\hline
\end{tabular}

\begin{tabular}{|c|c|c|c|c|c|c|c|c|c|c|c|c|}
\hline \multirow[b]{2}{*}{ SHIPMENT NUMBER } & \multirow[b]{2}{*}{37} & \multirow[b]{2}{*}{38} & \multirow[b]{2}{*}{39} & \multicolumn{4}{|c|}{ ALPNA CONTAMINATION } & \multicolumn{3}{|c|}{$\left(\mathrm{dpm} / 100 \mathrm{~cm}^{2}\right)$} & \multirow[b]{2}{*}{47} & \multirow[b]{2}{*}{48} \\
\hline & & & & 40 & 41 & 42 & 43 & 44 & 45 & 46 & & \\
\hline HEAD & $<21$ & $<2 \pm$ & $<16$ & $M D$ & $M D$ & $<25$ & $<16$ & $\mathrm{MIJ}$ & ND & $<22$ & $<14$ & $<23$ \\
\hline CASK TOP AND SIDES & $<21$ & $\langle z 1$ & $<1 \epsilon$ & NI & ND & $<25$ & $<16$ & NI & ND & $<22$ & $<14$ & $<23$ \\
\hline CAWITY VENT PDRT & $<21$ & $<21$ & $<16$ & $\mathrm{HD}$ & HD & $<25$ & $<16$ & $\mathrm{HI}$ & ND & $<22$ & $<14$ & $<23$ \\
\hline PRESSURE RELIEF & $<21$ & $<2 !$ & $<1 \epsilon$ & WI & ND & $<25$ & $<16$ & ND & $\mathrm{HI}$ & $<22$ & $<14$ & $<23$ \\
\hline PRESSURE TEST PDRT & $<21$ & $<21$ & $<16$ & ND & ND & $<25$ & $<16$ & $N D$ & MD & $<22$ & $\ll 14$ & $<23$ \\
\hline SIDES (UPFER) & $<21$ & $<21$ & $<16$ & $M D$ & $N D$ & $<25$ & 616 & $N D$ & $N D$ & 48 & $<14$ & $<23$ \\
\hline UPPER RUPTURE DISE & $<21$ & $<21$ & $<16$ & $M I$ & $+1 D$ & 〈25 & $<16$ & ND & $\mathrm{ND}$ & $<22$ & $\langle 14$ & $<23$ \\
\hline SIDES (KIDDLE) & $<21$ & $<21$ & $<16$ & $N I$ & $\mathrm{ND}$ & $<25$ & $<1 \epsilon$ & NI & $N D$ & $<2$ & 614 & $<23$ \\
\hline SIEES (LOUER) & $<21$ & $<21$ & $<16$ & ND & ND & $<25$ & $<16$ & ND & $\mathrm{NI}$ & $<22$ & $<14$ & $<23$ \\
\hline LOWER RUPTURE DISC & $<21$ & $<21$ & $\langle 1 \epsilon$ & $N D$ & $H D$ & $<25$ & $<16$ & ND & $\mathrm{ND}$ & $<22$ & $<14$ & $<23$ \\
\hline BASE ILEDGE & $<21$ & $<21$ & $<16$ & $\mathrm{H}$ & HD & $<25$ & $<16$ & $\mathrm{NI}$ & HI & $<22$ & $<14$ & $<23$ \\
\hline BASE (SIDE) & $<21$ & $<21$ & $\therefore 16$ & $\mathrm{HI}$ & ND & $<25$ & $<16$ & HD & HD & $<22$ & 14 & $<23$ \\
\hline DRAIN PORT & $<21$ & $<21$ & $<16$ & $4 I$ & ND & $\ll 25$ & $<16$ & $\mathrm{ND}$ & ND & $<22$ & $<14$ & $<23$ \\
\hline BASE (BOTTOM) & $<21$ & $<21$ & $\ll 16$ & $N D$ & ND & $<25$ & $<15$ & $N D$ & ND & 32 & $\langle 14$ & 223 \\
\hline TRUHIONS (LOWER) & $<21$ & $<21$ & $<1 \epsilon$ & $M D$ & $\mathrm{NI}$ & $<25$ & $<16$ & $\mathrm{NH}$ & HD & $<22$ & $\$ 14$ & $<23$ \\
\hline TRUNIONS (UPFER) & $<21$ & $<21$ & 115 & $\mathrm{HE}$ & NI & $<25$ & $H I$ & HD & $\$ D$ & $<22$ & $<14$ & $<23$ \\
\hline
\end{tabular}

(a) This data was obtained from industry records for 48 spent fue 1 cask shipments between 1978 and 1980 . 
that it is not a major problem at the current DOT Limits for newer casks. It was not possible in this study to collect enough data on this problem to determine the impacts of reducing the current DOT limits.

\subsection{Low-Leve] Radioactive Waste}

One hundred and sixteen smear samples were obtained from low-level radioactive waste containers. The containers ranged from steel drums, to overpacks, to plywood boxes. The amount of surface contamination found is recorded in Table 5.6-1. The smears with the highest contamination levels had beta-gamma activities of $1.23 \mathrm{dpm} / \mathrm{cm}^{2}$ and 0.52 $\mathrm{dpm} / \mathrm{cm}^{2}$, the largest of which is still about 170 times below the current DOT limits. No appreciable alpha contamination was found on any of the smears. The greatest amount of alpha activity found on a smear was about a factor of about 2000 times less then the current DOT limits.

\subsection{Frequency Distribution Summary}

Removable surface contamination frequency distributions are plotted in Figures 5.7-1 through 5.7-10. These plots show the number of smears versus the removable surface contamination level in disintegrations per

minute per $\mathrm{cm}^{2}$ of surface area. For radiopharmaceuticals, the removable alpha contamination frequency distribution is plotted in

Figure 5.7-1, and the removable beta-gamma contamination frequency distribution is plotted in Figure 5.7-2. All of the measured data are below the $10 \%$ relative counting error associated with the detection system, which is two orders of magnitude below the current DOT limit.

The frequency distributions for industrial sources are shown in Figure 5.7-3 for alpha and in Figure 5.7-4 for beta-gamma. Again, all of the measured data was below the $10 \%$ relative counting error detection limit for the instruments. In fact, for the highest beta-gama measurement $\left(0.14 \mathrm{dpm} / \mathrm{cm}^{2}\right.$ ) to have been considered significant (with a $10 \%$ relative counting error), about 50 minutes of counting would have been required. 
TABLE 5.6-1. Frequency Distribution Data for Low-Level Waste

\begin{tabular}{|c|c|c|c|c|}
\hline $\begin{array}{l}\text { Sample } \\
\text { Number }\end{array}$ & Package Type & Labeled Contents & $\begin{array}{l}\text { Beta-Gamma } \\
\left(\mathrm{dpm} / \mathrm{cm}^{2}\right)\end{array}$ & $\begin{array}{l}\text { Alpha } \\
\left(\mathrm{dpm} / \mathrm{cm}^{2}\right)\end{array}$ \\
\hline $\begin{array}{l}1 \\
2\end{array}$ & $\begin{array}{l}\text { Type A overpack } \\
\text { " }\end{array}$ & ${ }_{\|}^{\text {LSA }}$ & $\begin{array}{l}.12 \\
.01\end{array}$ & $\mathrm{Bkgrd}_{\|}^{(b)}$ \\
\hline 3 & $"$ & $"$ & .12 & $"$ \\
\hline 4 & " & $"$ & .35 & " \\
\hline 5 & $"$ & $"$ & .16 & $"$ \\
\hline 6 & $"$ & $"$ & .06 & $"$ \\
\hline 7 & $"$ & $"$ & .29 & " \\
\hline 8 & $"$ & $"$ & 1.23 & $"$ \\
\hline 9 & $"$ & $"$ & .17 & $"$ \\
\hline 10 & " & $"$ & .12 & $"$ \\
\hline 11 & $"$ & $"$ & .23 & $"$ \\
\hline 12 & $"$ & $"$ & .04 & $n$ \\
\hline 13 & " & $"$ & .52 & $"$ \\
\hline 14 & Barrel drum & LSA & .13 & $n$ \\
\hline 15 & " & $"$ & .07 & $"$ \\
\hline 16 & a & $"$ & .07 & $"$ \\
\hline 17 & $"$ & $"$ & .07 & $"$ \\
\hline 18 & $"$ & $"$ & .10 & $"$ \\
\hline 19 & $"$ & $"$ & .01 & $"$ \\
\hline 20 & " & $"$ & .07 & $"$ \\
\hline 21 & Plywood Box & LSA & .06 & $"$ \\
\hline $\begin{array}{l}22 \\
23\end{array}$ & $"$ & " & $\begin{array}{l}\text { Bkgrd (a) } \\
.01\end{array}$ & " \\
\hline 24 & $"$ & $"$ & .02 & $"$ \\
\hline 25 & Overpack & -- & .02 & $"$ \\
\hline 26 & $"$ & -- & .04 & $"$ \\
\hline 27 & $"$ & -. & .08 & $"$ \\
\hline 28 & $"$ & -. & .01 & $"$ \\
\hline 29 & " & -- & .07 & $\#$ \\
\hline
\end{tabular}


TABLE 5.6-1. (Cont'd)

Samp Te
Number

Number Package Type

$\begin{array}{cc}30 & " \\ 31 & " \\ 32 & \text { Barrel drums } \\ 33 & " 1 \\ 34 & " \\ 35 & " \\ 36 & " \\ 37 & "\end{array}$

38 Barrel drums

39

40

41

42

43

44

45

46

47

48

49

50

51

52

53

54

55

56

57

58

59

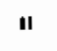

II

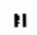

II
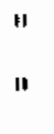

"1
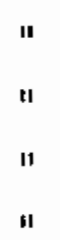

"1

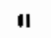

I)

II

"

"

"

"

"

"
Labeled Contents

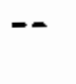

LSA

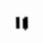

II

II

II

"

LSA

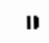

II

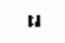

"

"

"

n

II

w

II

"

"

"

1

${ }^{3} \mathrm{H},{ }^{14} \mathrm{C},{ }^{32} \mathrm{p}(.001 \mathrm{Cj})$

${ }^{3} \mathrm{H},{ }^{14} \mathrm{C},{ }^{125} \mathrm{I}(.003 \mathrm{Ci})$

${ }^{3} \mathrm{H}\left(.9 \times 10^{-3} \mathrm{Ci}\right)$

${ }^{129},{ }^{57} \mathrm{Co}$ (3 ${ }^{\mathrm{Ci}}$ )

${ }^{3} \mathrm{H},{ }^{14} \mathrm{C},{ }^{32} \mathrm{P}(.001 \mathrm{Ci})$

${ }^{3} \mathrm{H},{ }^{14} \mathrm{C},{ }^{125} \mathrm{I} \quad(.003 \mathrm{Ci})$

${ }^{3} \mathrm{H}\left(.9 \times 10^{-3} \mathrm{Ci}\right)$

${ }^{125} \mathrm{I},{ }^{57} \mathrm{Co}$
Beta-Gamma $\left(\mathrm{dpm} / \mathrm{cm}^{2}\right)$ Alpha, $\left(\mathrm{dpm} / \mathrm{cm}^{2}\right)$

.03

.05

.07

.01

.05

.02

.03

.04

.09

.06

.01

.05

.01

.05

.02

.09

.04

.05

.03

.02

.01

.01

Bkgrd

.01

Bkgrd

.06

.02

.06

.04

Bkgrd
"

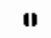

u

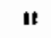

"

"

"

II

Bkgrd

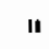

It

|

II

II

II

II

II

n

II

u

"

"

"

II

11

II

11

II

"

" 
TABLE 5.6-1. (Cont'd)

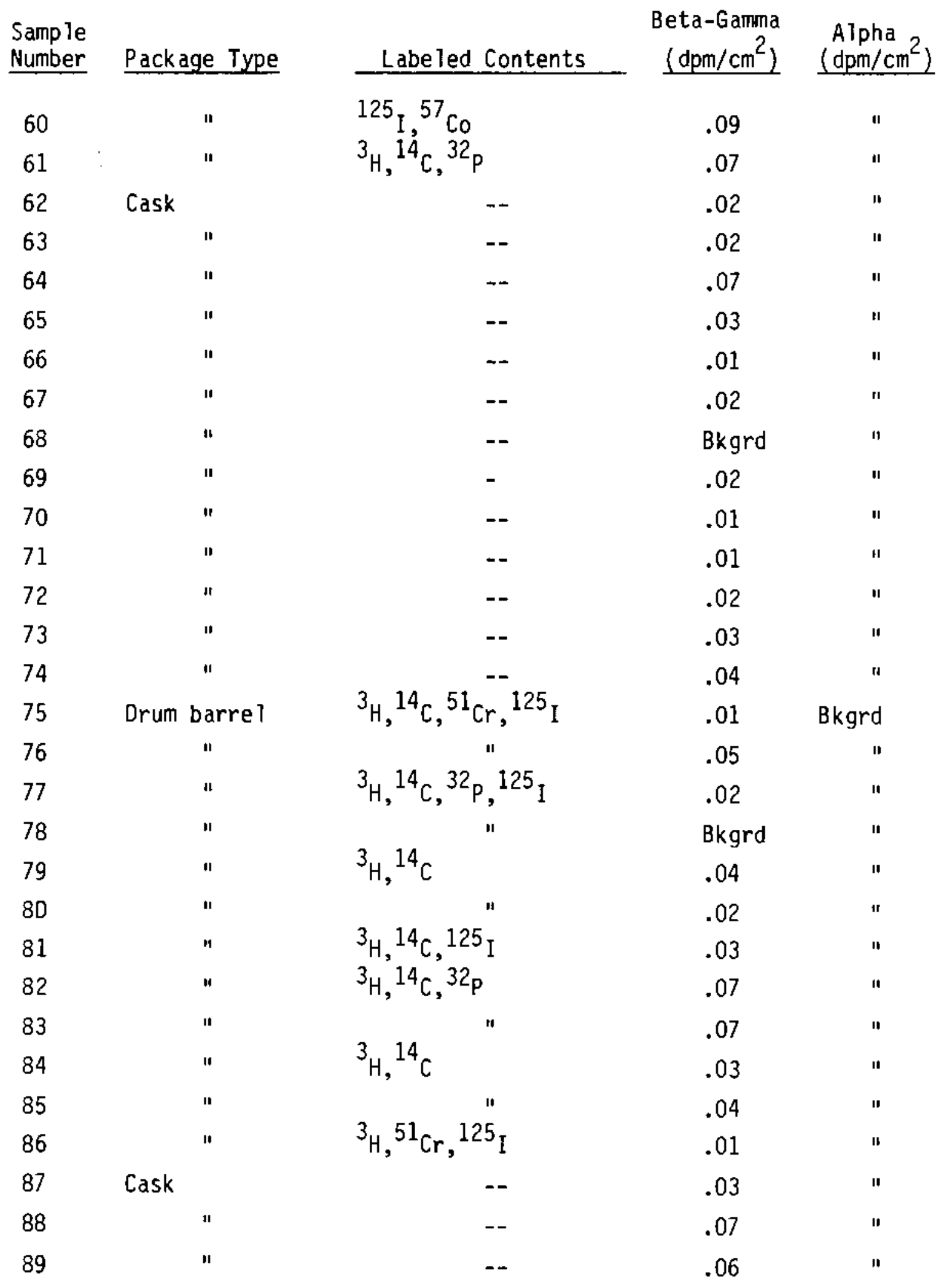


TABLE 5.6-1. (Cont'd)

\begin{tabular}{|c|c|c|c|c|}
\hline $\begin{array}{l}\text { Samp le } \\
\text { Number }\end{array}$ & Package Type & Labeled Contents & $\begin{array}{l}\text { Beta-Gamma } \\
\left(\mathrm{dpm} / \mathrm{cm}^{2}\right)\end{array}$ & $\begin{array}{l}\text { ATpha } \\
\left(\mathrm{dpm} / \mathrm{cm}^{2}\right)\end{array}$ \\
\hline 90 & $"$ & -- & .06 & $"$ \\
\hline 91 & $"$ & -- & .05 & $"$ \\
\hline 92 & " & -- & .07 & " \\
\hline 93 & $"$ & -- & .04 & $"$ \\
\hline 94 & $"$ & -- & .03 & $"$ \\
\hline 98 & Overpack & LSA & .02 & $"$ \\
\hline 99 & " & $"$ & .09 & $"$ \\
\hline 100 & $"$ & $"$ & .12 & $"$ \\
\hline 101 & $"$ & $"$ & .17 & $"$ \\
\hline 102 & $"$ & $"$ & .15 & $"$ \\
\hline 103 & $"$ & $"$ & .14 & $"$ \\
\hline 104 & $"$ & $"$ & .1 & $"$ \\
\hline 105 & $"$ & $"$ & .14 & $"$ \\
\hline 106 & $"$ & $"$ & .18 & $"$ \\
\hline 107 & $"$ & $"$ & .07 & $"$ \\
\hline 108 & $"$ & $"$ & .19 & $"$ \\
\hline 110 & $"$ & $"$ & .05 & $"$ \\
\hline 111 & Truck & -- & .09 & $"$ \\
\hline 112 & $"$ & $\overline{\overline{14}}(.002 \mu \mathrm{Ci})$ & $\begin{array}{l}.04 \\
.12\end{array}$ & $"$ \\
\hline $\begin{array}{l}113 \\
114\end{array}$ & Barrel $_{"}$ & $\begin{array}{l}14[(.002 \mu L 7) \\
--\end{array}$ & .12 & $"$ \\
\hline 115 & Barrel & $\overline{125 I}$ & $\begin{array}{l}.14 \\
.22\end{array}$ & $\begin{array}{l}\text { Bkgrd } \\
.01\end{array}$ \\
\hline $\begin{array}{l}116 \\
117\end{array}$ & $"$ & -- & .21 & Bkgrd \\
\hline 118 & $"$ & $\overline{125 I}$ & $\begin{array}{l}.21 \\
.19\end{array}$ & $\begin{array}{l}\text { 8kgrd } \\
.01\end{array}$ \\
\hline
\end{tabular}

(a) The average background (8kgrd) count rate for beta-gamma measurements of low-level waste was $105 \mathrm{cpm}$.

(b) The average background (Bkgrd) count rate for alpha measurements of low-level waste was $1 \mathrm{cpm}$. 


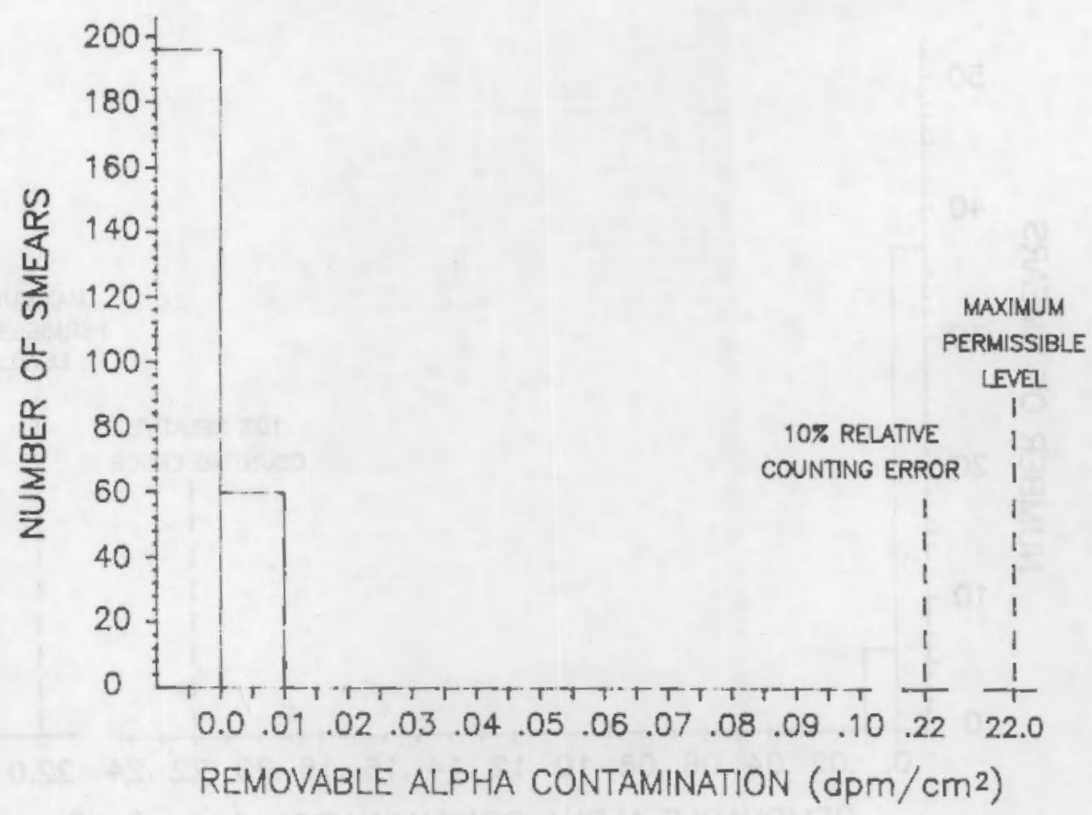

FIGURE 5.7-1 - Frequency Distribution for Radiopharmaceuticals Alpha Contamination

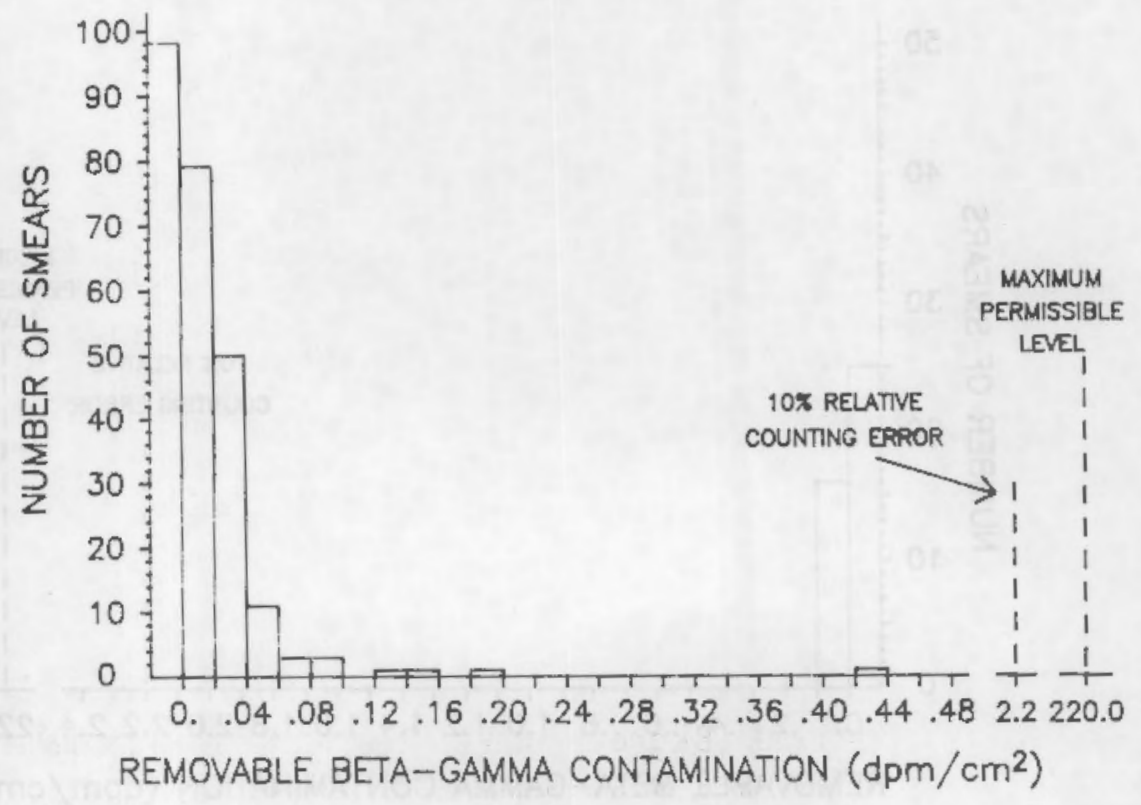

FIGURE 5.7-2 Frequency Distribution for Radiopharmaceuticals Beta-Gamua Contamination 


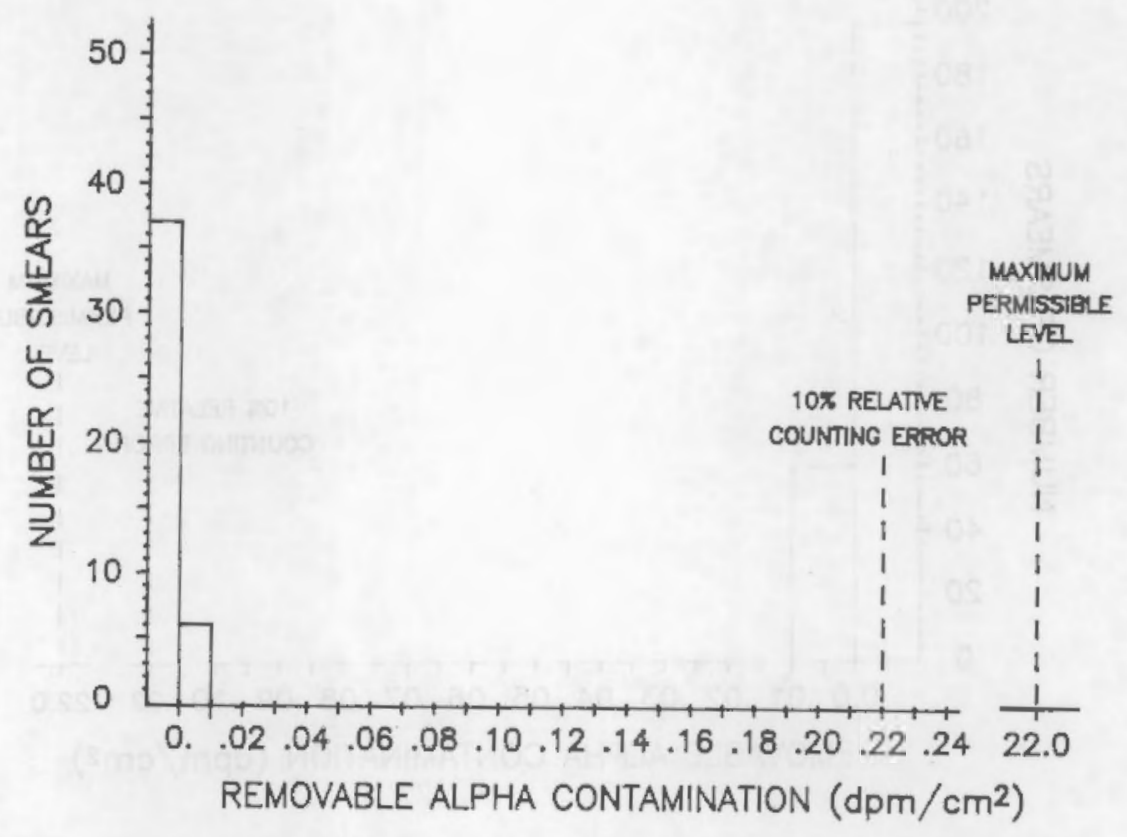

FIGURE 5.7-3 Frequency Distribution for Industrial Sources - Alpha Contamination

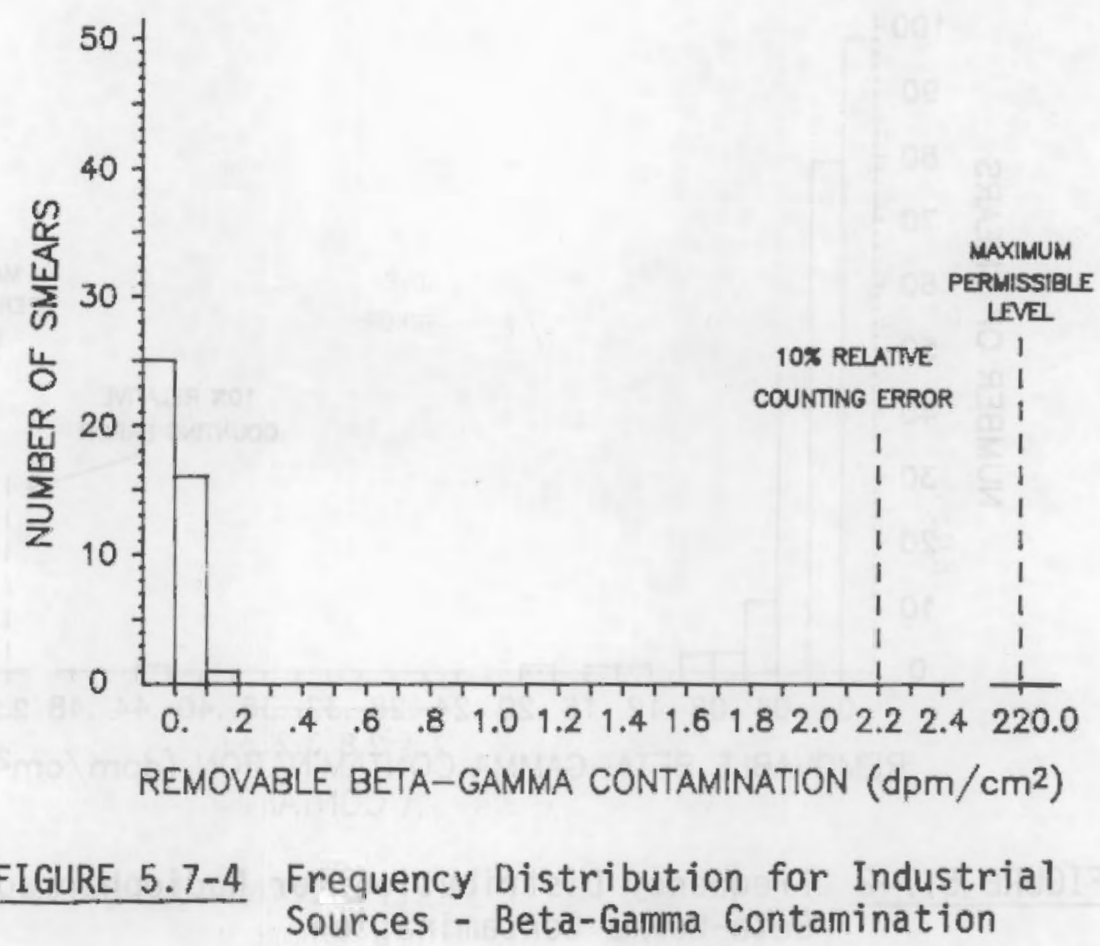




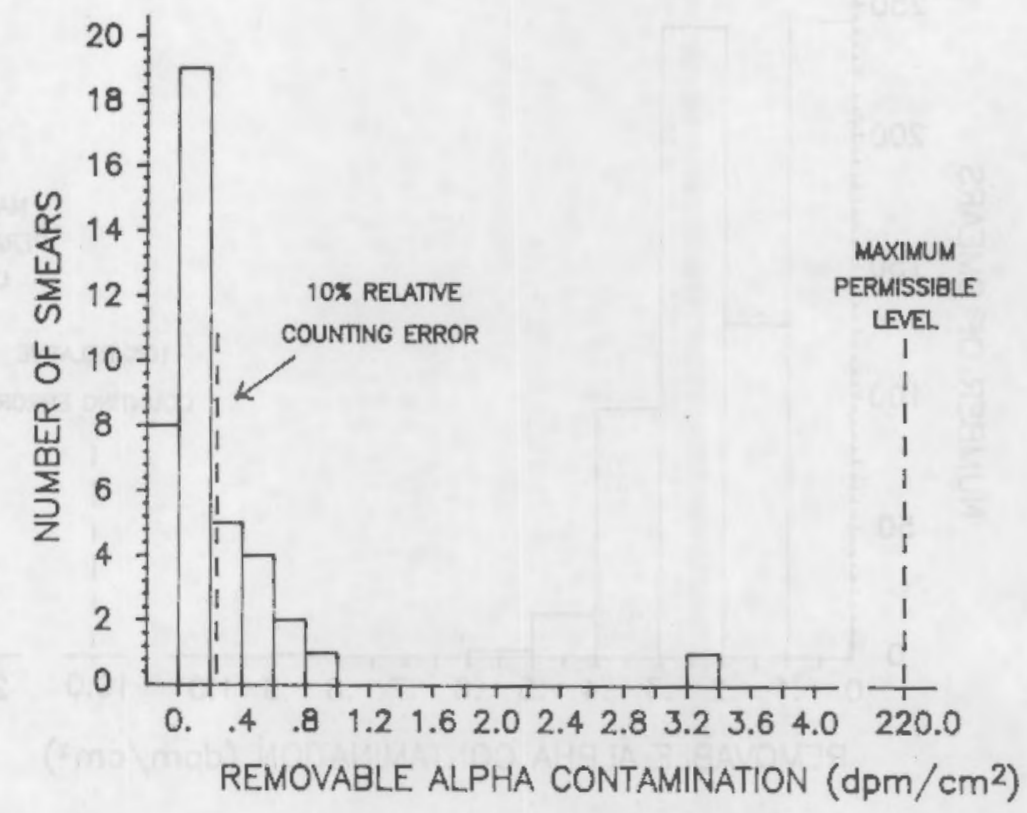

FIGURE 5.7-5 Frequency Distribution for Uranium Shipments - Alpha Contamination

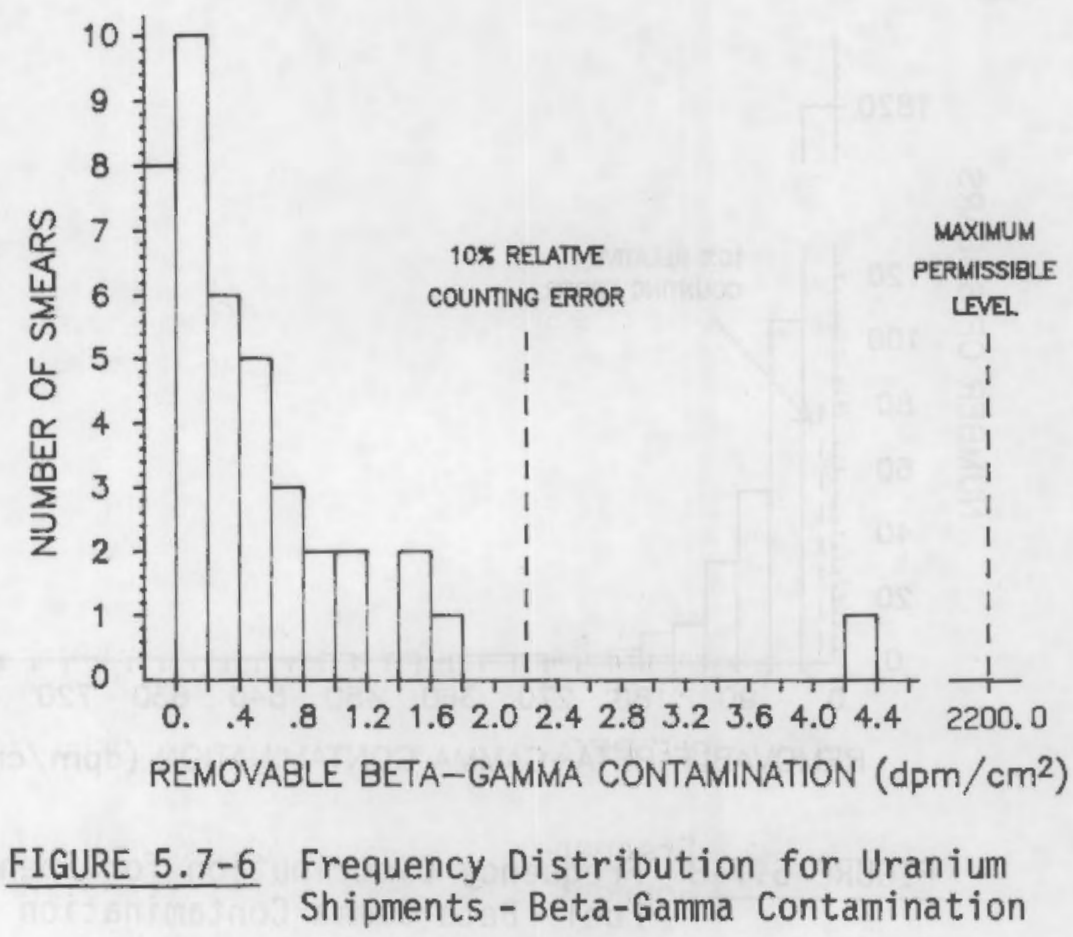




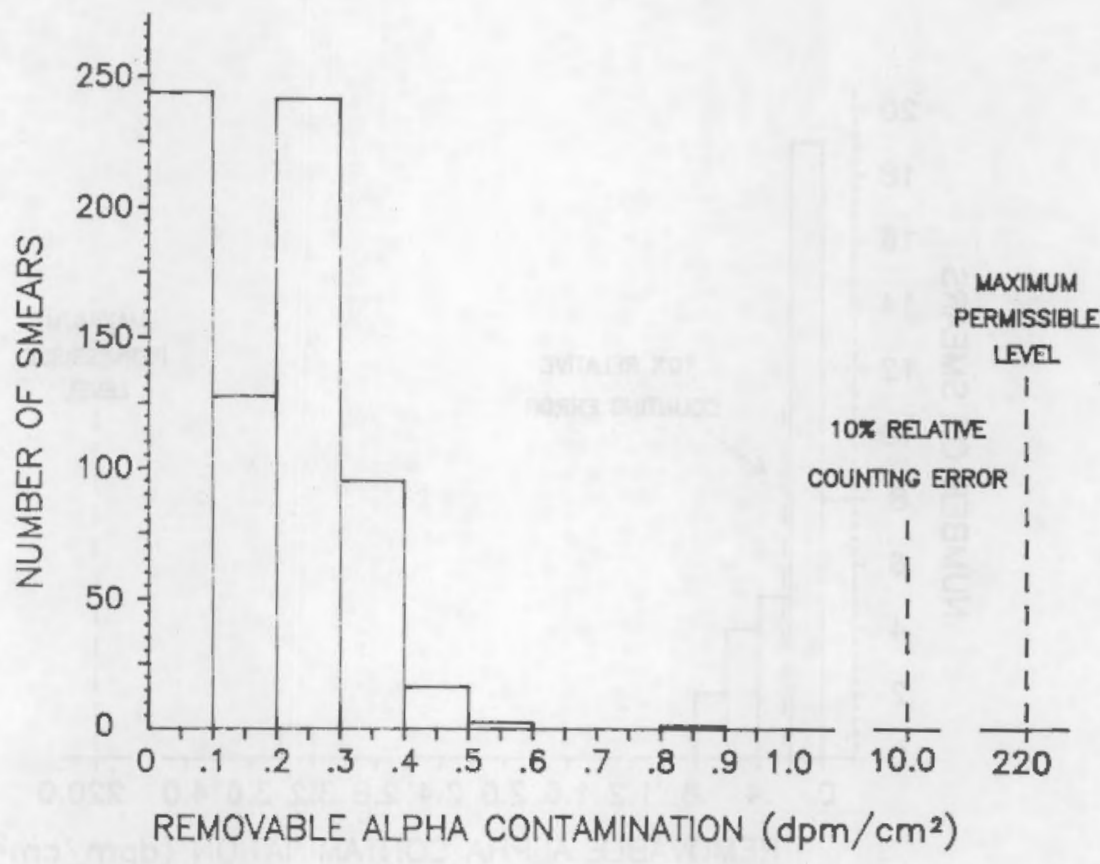

FIGURE 5.7-7 Frequency Distribution for Spent Fuel - Alpha Contamination (Exclusive Use Shipments)

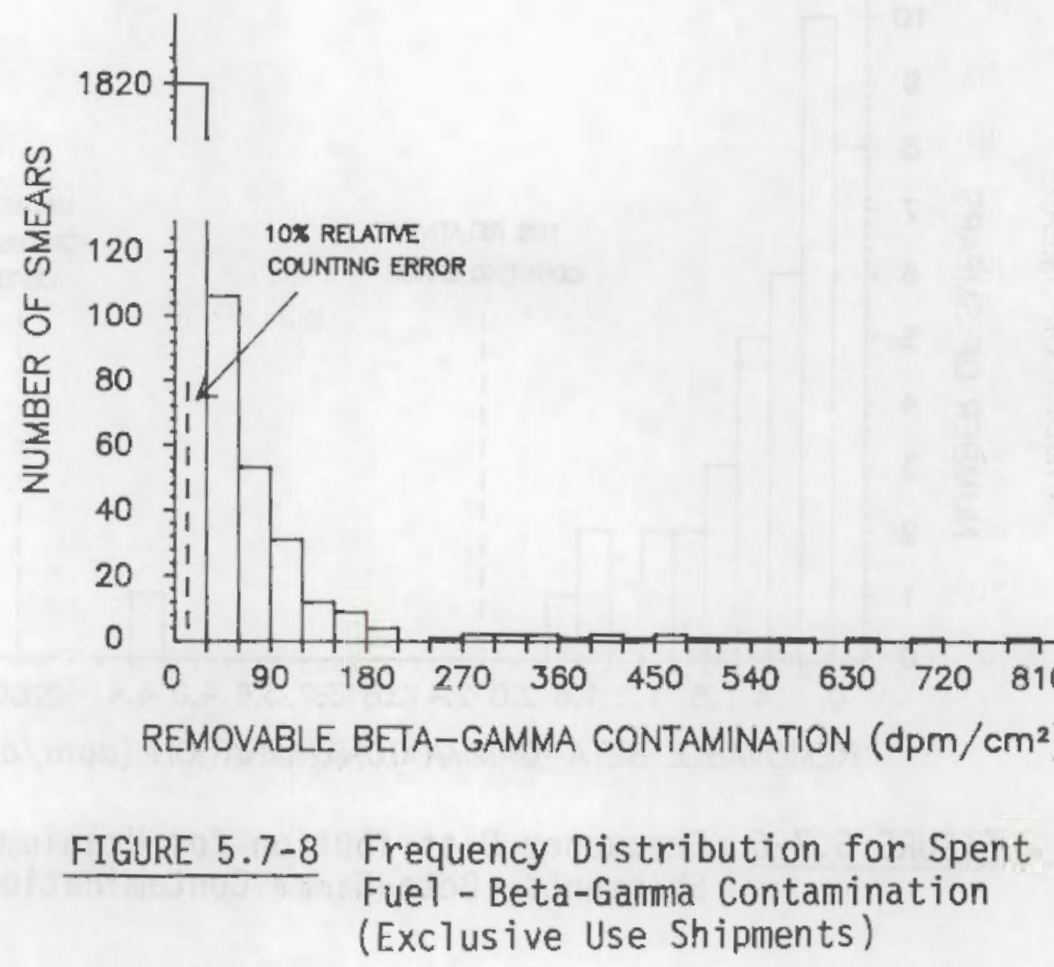




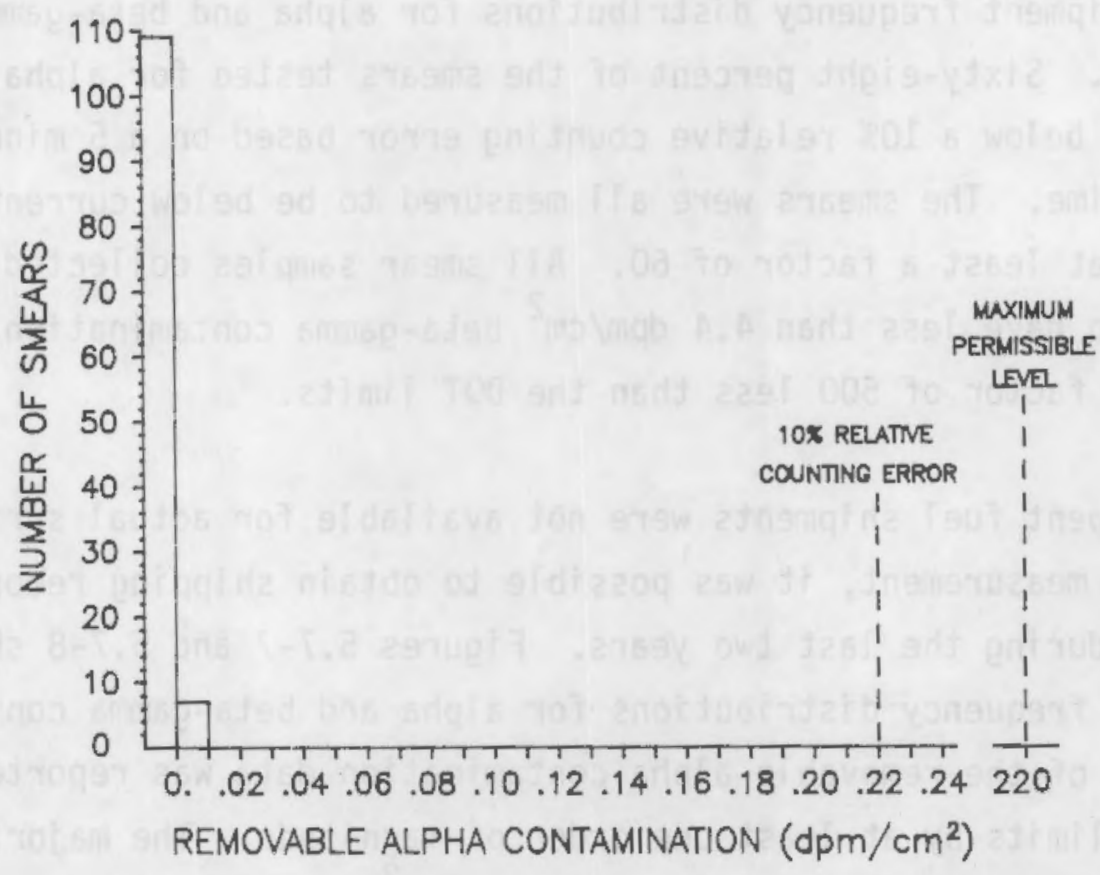

FIGURE 5.7-9 Frequency Distribution for Low-Level Radioactive Waste - Alpha Contamination (Exclusive Use Shipments)

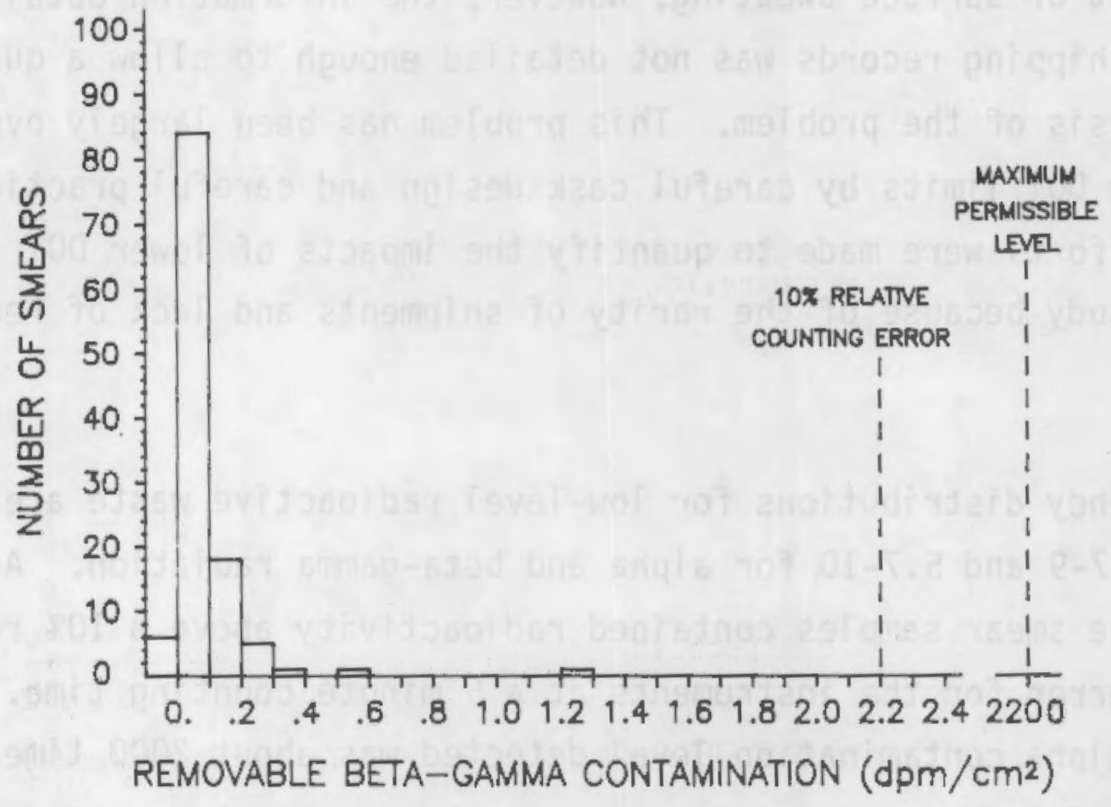

FIGURE 5.7-10 Frequency Distribution for Low-Level Radioactive Waste - Beta-Gamma Contamination (Exclusive Use Shipments) 
For nuclear fuel cycle materials, uranium shipments $\left(\mathrm{U}_{3} \mathrm{O}_{8}\right.$ and $\left.\mathrm{UF}_{6}\right)$ and spent fuel shipments were considered. Figures 5.7-5 and 5.7-6 show the uranium shipment frequency distributions for alpha and beta-gamma contamination. Sixty-eight percent of the smears tested for alpha contamination are below a $10 \%$ relative counting error based on a 5 minute counting time. The smears were al1 measured to be below current DOT Limits by at least a factor of 60 . All smear samples collected were detected to have less than $4.4 \mathrm{dpm} / \mathrm{cm}^{2}$ beta-gamma contamination, which is about a factor of 500 less than the DOT limits.

Although spent fuel shipments were not available for actual surface contamination measurement, it was possible to obtain shipping records for shipments during the last two years. Figures 5.7-7 and 5.7-8 show the spent fuel frequency distributions for alpha and beta-gamma contamination. All of the removable alpha contamination data was reported to be below DOT limits by at least one order of magnitude. The majority of the beta-gamma smear data is below $30 \mathrm{dpm} / \mathrm{cm}^{2}$, and on $1 y 1 \%$ of the smears had a contamination level greater than current nonexclusive use limits. Removable surface contamination levels on spent fuel casks may increase as a result of surface sweating, however, the information obtained from industry shipping records was not detailed enough to allow a quantitative analys is of the problem. This problem has been largely overcome at current DOT limits by careful cask design and careful practices. No further efforts were made to quantify the impacts of lower DOT limits in this study because of the rarity of shipments and lack of recorded data.

The frequency distributions for low-level radioactive waste are shown in Figures 5.7-9 and 5.7-10 for alpha and beta-gamma radiation. Again, none of the smear samples contained radioactivity above a $10 \%$ relative counting error for the instruments at a 5 minute counting time. The greatest alpha contamination level detected was about 2000 times less than the DOT limit, and the greatest beta-gamma level detected was about 170 times less than the DOT limit. 
A limited Ge-Li gamma-spectra analysis was performed on the highest contaminated smear from the low-level waste shipments. The results showed very small amounts of ${ }^{137} \mathrm{Cs},{ }^{54} \mathrm{Mn},{ }^{58} \mathrm{Co}$, and ${ }^{60} \mathrm{Co}$. The total activity on the sample was barely above background. 


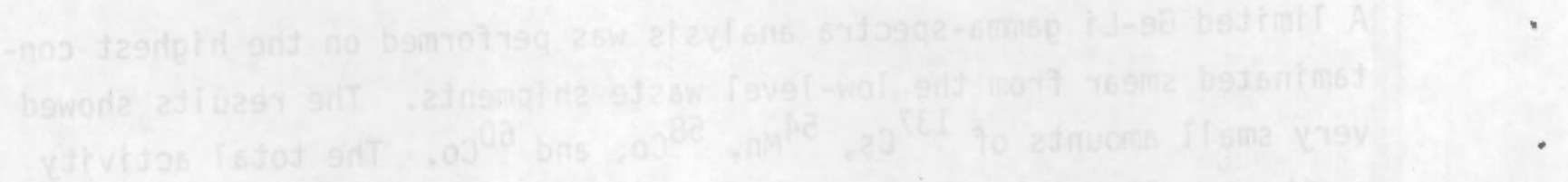

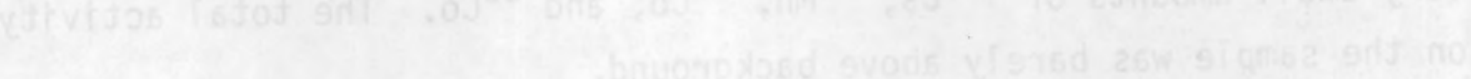




\section{COMMENTS ON RESULTS}

The results presented in this study are intended to represent current information concerning removable surface contamination on radioactive materials transportation containers. The information presented in this report was obtained from literature sources, from industry contacts and personal observations and measurements. The information was carefully selected to be representative of current practices and conditions. Because of the wide range of specific conditions encountered, a range of scenarios was considered for both the radiation dose and economic analyses. We feel that by presenting the results of these scenarios we can display the complexity of some of the surface contamination problems and still give example results. It should be remembered that the results presented for the dose and economic analyses are based on key assumptions. We have attempted to make realistic assumptions wherever possible; however, changes in the assumptions will, of course, change the results obtained.

We held discussions with representatives of industry involved in radioactive materials transportation concerning a possible reduction of DOT regulations on removable surface contamination levels. As might be expected, the representatives contacted were unanimous in their disapproval of lowering the limits. The most frequent comment was that lower limits would require a longer monitoring time to demonstrate compliance. This would cause a delay in the shipping process. One site had a two-hour time span to monitor incoming shipments before releasing the delivery trucks; thus, any delays could adversely affect the entire operation. Furthermore, radiopharmaceuticals with short half-lives or that require low storage temperatures need to be shipped with a minimum of delay.

Some industry representatives also felt that lowering the limits would have a minimal health benefit while substantially increasing costs. Comment was made regarding contamination occurences. A contamination 
problem often necessitates the tracing of the contaminated delivery truck through all stops made prior to discovery of contamination in order to determine the source of contamination and the potential spread of contamination. An incident of this type requires the involvement of three groups: the company receiving the contaminated container, state officials, and federal officials. This procedure is an expensive hidden cost, and such incidents are currently infrequent for a given site. However, if the limits are lowered they might become more frequent.

The vast majority of shipments are currently substantially below DOT limits for removable surface contamination according to the industries we contacted and the data we collected. With the exception of spent fuel casks, the primary cost impacts of lower limits would not be increased decontamination costs. The primary cost impact would be increased monitoring costs, but this impact may be small compared to potential production delays, increased transit costs, and other indirect costs that may be associated with reduced limits. 


\section{DISTRIBUTION}

No. of

Copies

OFFSITE

A. A. Churm

DOE Chicago Patent Group

9800 South Cass Avenue

Argonne, IL 60439

2 DOE Technical Information Center

US Nuclear Regulatory Commission

10 Dr. Anthony Tse

US Nuclear Regulatory Commission

Mail Station NL 5650

Washington, DC 20555

\section{ONSITE}

50 Pacific Northwest Laboratory

J. M. Aldrich

B. J. Harrer

R. Harty

W. E. Kennedy, Jr. (38)

D. W. Murphy

E. C. Watson

Technical Information (5)

Publishing Coordination (2) 


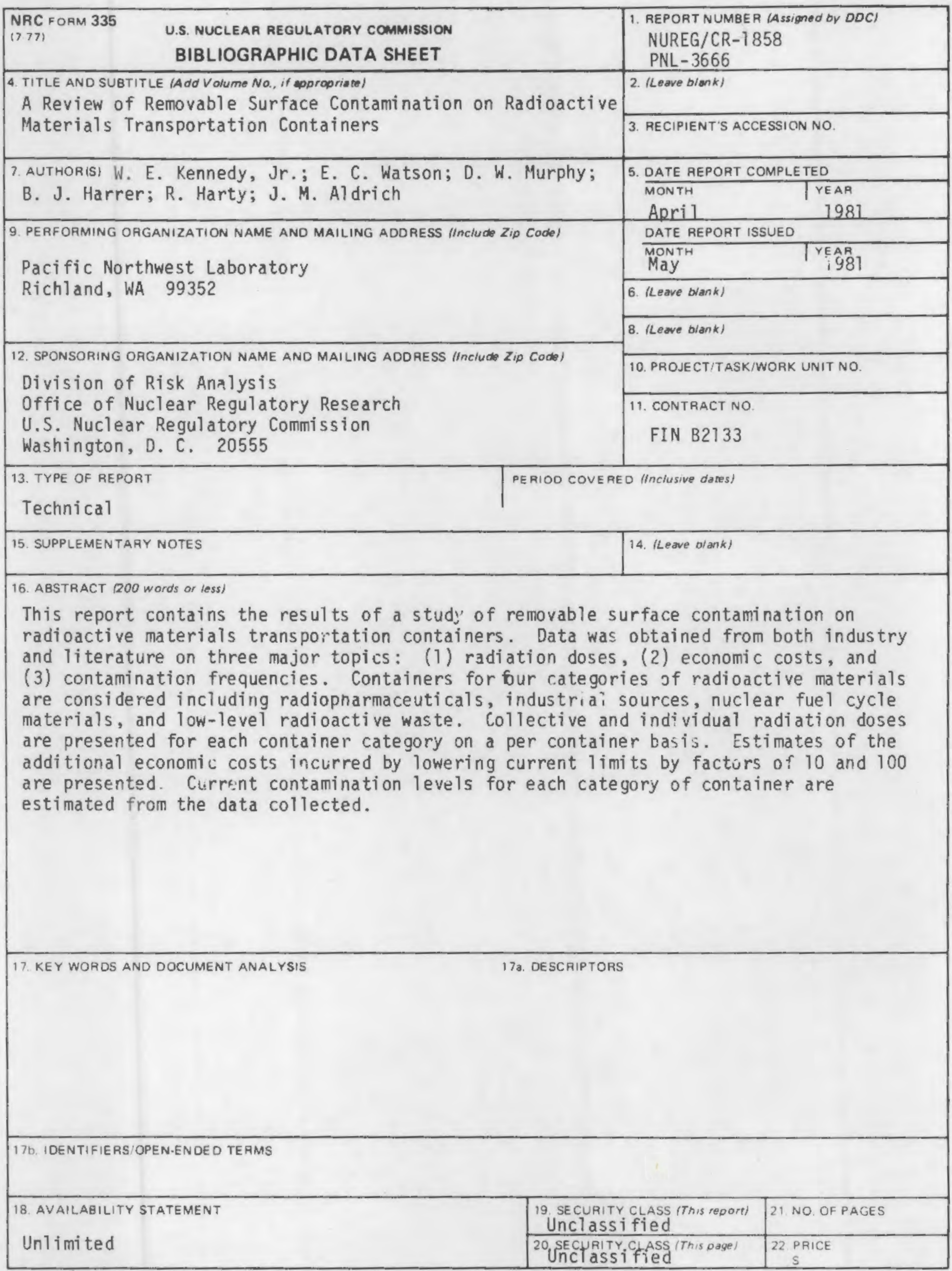




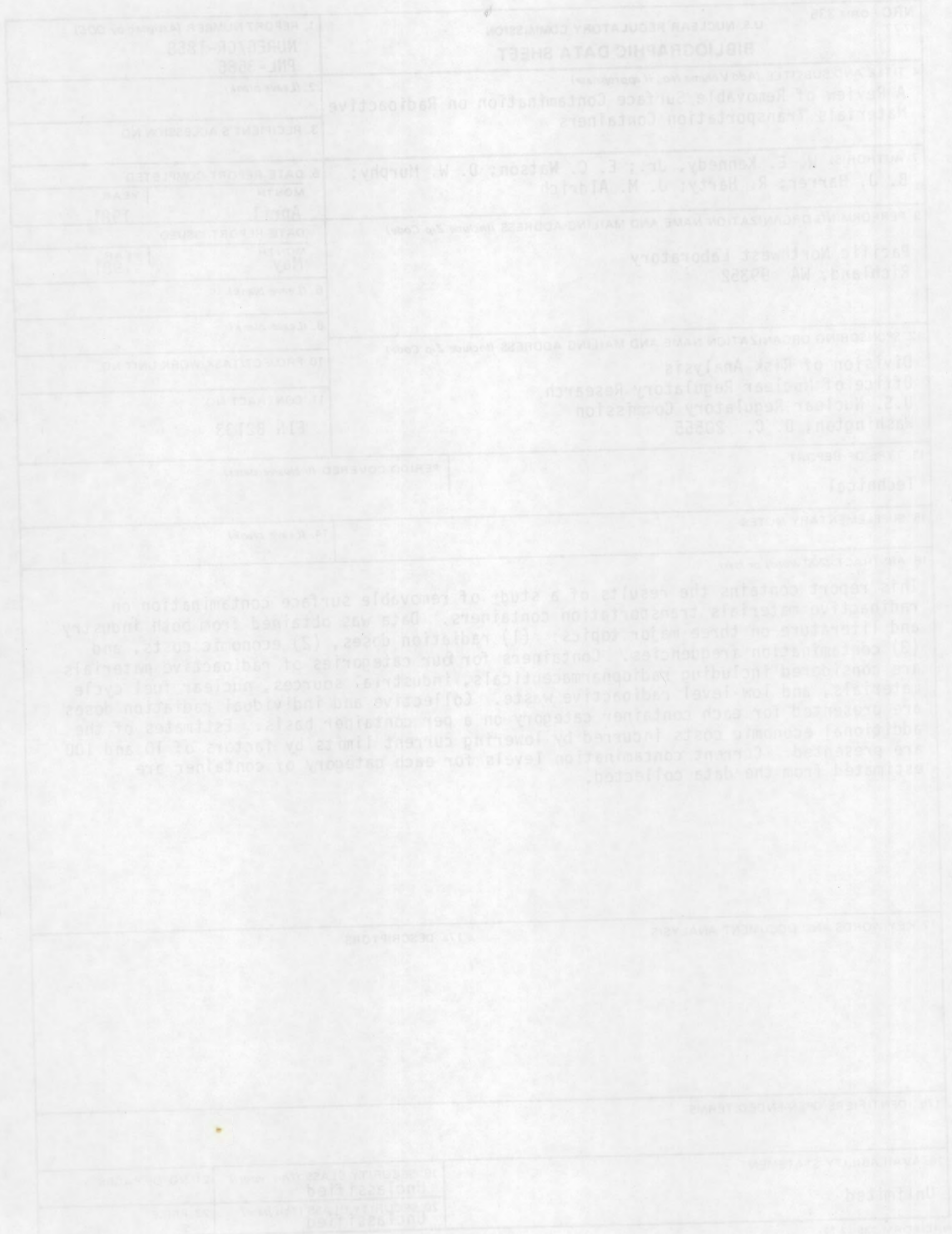

